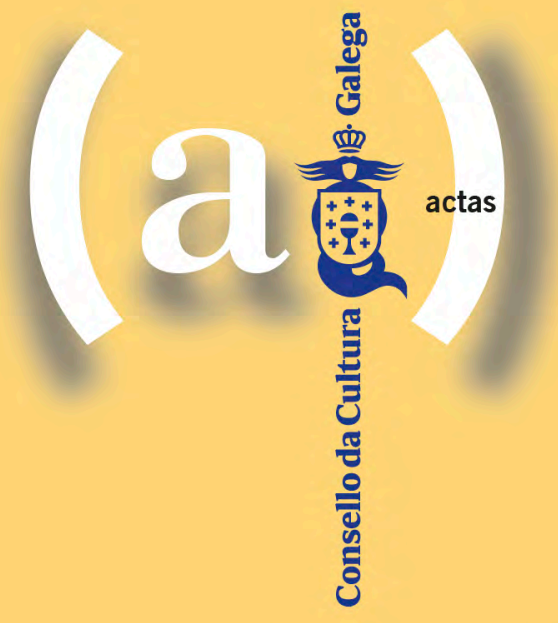

FRANCISCO DÍAZ-FIERROS VIQUEIRA COORDINADOR

\title{
Unha nova xeración de lumes? Actas do Coloquio Galaico-Portugués sobre Incendios Forestais
}

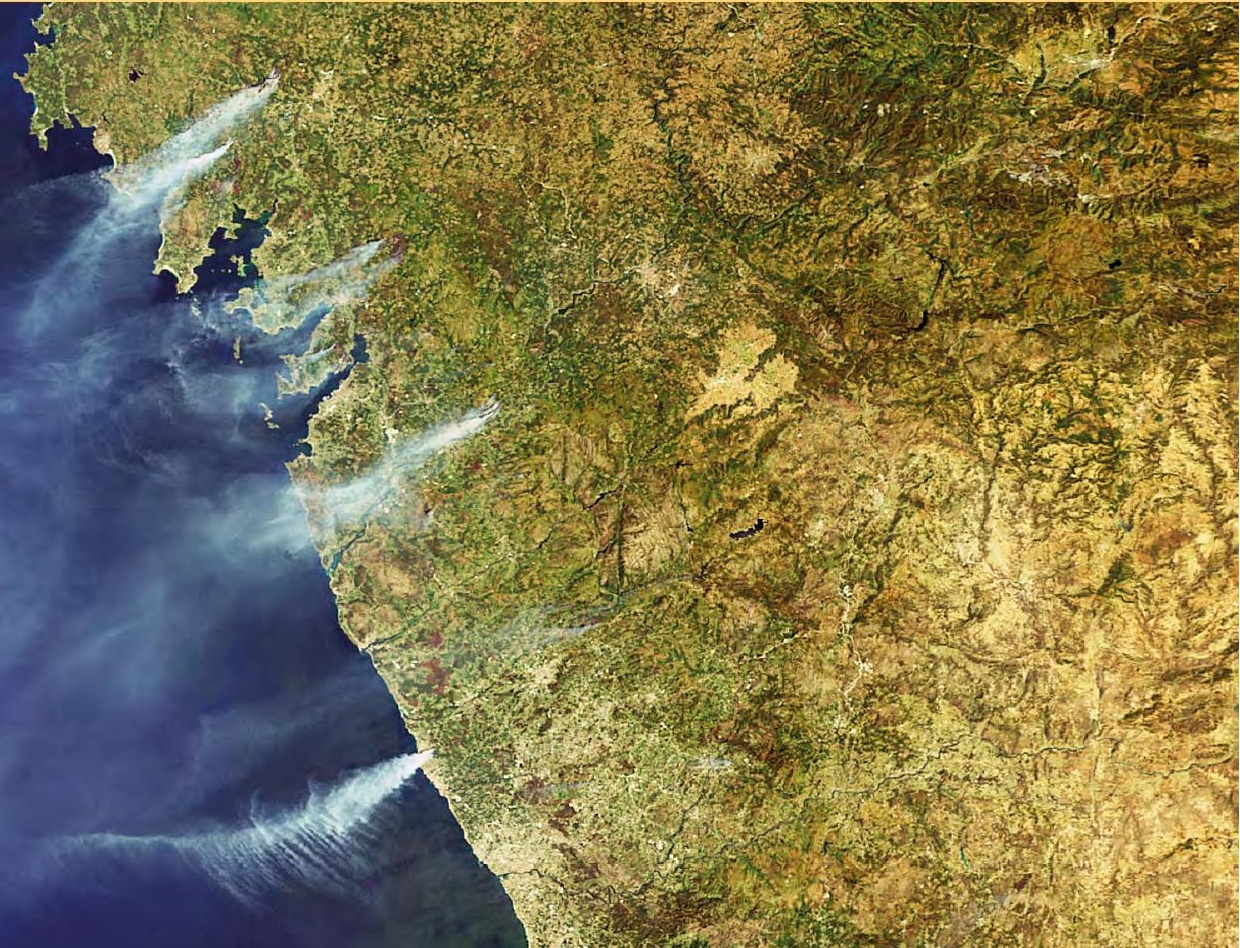



Unha nova xeración de lumes?

Actas do Coloquio Galaico-Portugués sobre Incendios Forestais 


\section{Edita}

(c) CONSELLO DA CULTURA GALEGA, 2021

Pazo de Raxoi $\cdot 2^{0}$ andar · Praza do Obradoiro

15705 Santiago de Compostela

T 981957202 Fax 981957205

corre0@consellodacultura.gal

www.consellodacultura.gal

\section{Imaxe da cuberta}

European Space Agency (ESA)

\section{Proxecto gráfico}

Imago Mundi Deseño

\section{Maquetación e impresión}

Lugami Artes Gráficas

Depósito legal: C 564-2021

ISBN 978-84-17802-29-5

DOI: 10.17075/unxl.2021 


\section{Unha nova xeración de lumes? Actas do Coloquio Galaico-Portugués sobre Incendios Forestais}

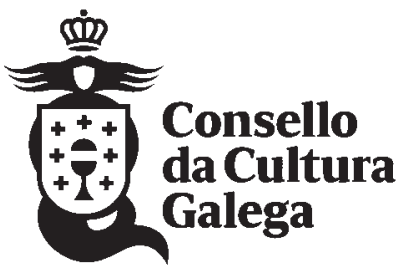


Presentación 


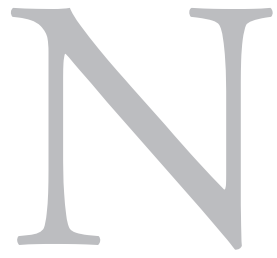

os últimos tempos estase a constatar que os incendios forestais afectan cada vez con máis virulencia a edificacións e persoas. Esa interface urbano-forestal, que até hai pouco só illadamente era pasto das lapas, agora vese decote ameazada polos lumes, de tal xeito que a súa protección se converte no obxectivo prioritario das operacións de extinción. Así mesmo, semella que a extensión e a intensidade dos incendios se van incrementando como consecuencia de situacións meteorolóxicas especialmente adversas, que se suman ao amoreamento excesivo de combustibles. Para moitos, o cambio climático pode estar detrás destas novas condicións.

Todo o anterior leva a diversos analistas a indicar que estamos diante dun cambio cualitativo na incidencia e características dos incendios forestais que non fará máis que incrementarse nos próximos anos. Fálase dunha nova xeración de lumes.

Para tratar destes temas, nuns territorios tan castigados polos incendios como son Galicia e Portugal, o Consello da Cultura Galega (CCG) presenta este libro, no que se recollen a maioría dos relatorios do Coloquio Galaico-Portugués realizado en xaneiro do ano 2018. Nel, a partir das achegas de especialistas portugueses e galegos, téntase definir até onde sexa posible esta nova situación e discutir que medidas deberían implementarse para atenuar os seus eventuais impactos.

Analizarase a historia da problemática dos incendios en Galicia e Portugal, así como as características do cambio global que teñen unha maior incidencia no risco de que se produzan. Os problemas estruturais da agricultura e o aínda dominante desorde na silvicultura consideraranse como factores relevantes na particular incidencia que teñen os lumes nestes territorios. E, finalmente, discutiranse as características do espazo urbano-forestal e os riscos derivados delas, así como as novas medidas de loita contra os incendios que deberían poñerse en práctica nun futuro. 
En definitiva, unha achega máis fronte a este endémico problema, ante o cal o Consello da Cultura Galega nunca se mostrou indiferente, xa que se trata da terceira publicación dedicada a esta temática, despois de Os incendios forestais en Galicia (2006) e Por unha nova cultura forestal fronte aos incendios. Informes e conclusións (2007).

\section{Francisco Díaz-Fierros Viqueira}



$\frac{10}{10}$

Índice 


\section{PRESENTACIÓN}

Francisco Díaz-Fierros Viqueira

13 Incendios forestais en Galicia e Portugal

Francisco Díaz-Fierros Viqueira

49 Os incendios forestais do cambio global xa estan aquí.

Un desafío e unha ocasión para lograr unha resposta social consensuada

José A. Vega, Stéfano Arellano-Pérez, Cristina Fernández, Teresa Fontúrbel

e Ana Daría Ruiz

121 Factores estruturais que contribúen ao problema dos incendios en Galicia: mudanzas no medio rural e deficiencias na xestión do territorio Edelmiro López Iglesias

151 Orde e desorde no espazo forestal Juan Picos Martín

203 Lumes na interface urbano-florestal

Luciano Lourenço

233 Preparação do sistema de defesa para comportamento extremo do fogo António Salgueiro 


\section{INCENDIOS FORESTAIS EN GALICIA E PORTUGAL*}

Francisco Díaz-Fierros Viqueira Catedrático emérito da USC

DOI: 10.17075/unxl.2021.001

* Agradézolle ao profesor Luciano Lourenço as suxestións achegadas a este traballo. 



\section{INTRODUCIÓN}

No outono do 2018, a NASA estadounidense publicou unha gráfica sobre os incendios acaecidos no mundo no ano 2017 e a impresión que transmitía era que por todo o planeta había sinais de tal fenómeno. Imaxe que dalgún xeito estaba a dicirnos que os efectos do lume eran algo propio do planeta Terra e que practicamente ningún recuncho do globo estaba libre deles.

De todas as maneiras, se a representación se fixese con máis detalle e, sobre todo, se tivese en conta a proxección temporal dos incendios, xurdirían determinadas zonas do mundo nas que os lumes se concentrarían dun xeito máis relevante, como acontece, por exemplo, coas sabanas e, principalmente, cos territorios de clima mediterráneo. Este último tipo de clima sitúase entre os $30^{\circ}$ e $45^{\circ}$ tanto do hemisferio norte como do sur e nel atópanse territorios tales que California, a cunca do mar Mediterráneo, Chile, Sudáfrica e a Australia do suroeste, países onde os incendios dos seus espazos forestais non só están a acaparar as novas de actualidade dos xornais, senón que na súa propia historia foron deixando pegadas evidentes na cultura e na paisaxe. Esta sensibilidade dos climas mediterráneos aos incendios forestais derívase, de maneira fundamental, das características de inflamabilidade que lle transmiten ao combustible vexetal: uns outonos-invernos de temperaturas mornas e chuvias relativamente abundantes que favorecen o crecemento da biomasa, que despois, coa característica seca estival propia destes climas, se volve combustible con facilidade.

O clima mediterráneo euro-afro-asiático non só é o máis extenso do planeta, senón que tamén foi o primeiro que deu orixe a unha civilización agrícola e a unha cultura que foi a base da civilización occidental actual. Como sinala S. J. Pyne (1997), este mediterráneo é bastante máis que un clima, pois define «a place, a climate, a biota and a paradigm». O lume integrouse na súa propia historia e, para alén de ser a ferramenta fundamental coa que as prácticas agrarias e 
pastorais foron conquistando territorios cada vez máis abruptos, deu lugar, así mesmo, a unha vexetación adaptada á convivencia cos incendios e a un territorio no que os seus sinais ficaban claros e persistentes na paisaxe. Neste espazo, a fachada máis occidental, a que mira cara ao Atlántico, quedou cunhas características propias e diferenciadas do resto, pois as masas húmidas procedentes do océano fixeron que o período de outono-inverno acollese unhas precipitacións moito máis abondosas e dilatadas no tempo que noutros territorios da cunca mediterránea (Coimbra, $1082 \mathrm{~mm}$ anuais, fronte a, por exemplo, Roma, con $798 \mathrm{~mm}$, e Xerusalén, con $477 \mathrm{~mm}$ ), as cales, sumadas ás temperaturas mornas de todo o ano, daban orixe a unhas condicións óptimas para o crecemento vexetal, que son, sen dúbida, as máis importantes de toda a cunca.

Como consecuencia destas condicións tan favorables para o amoreamento do combustible, Galicia e Portugal, que son os dous países que miran ao Atlántico desde o Mediterráneo, son tamén os que padecen o maior número de incendios de todo este territorio (en especial desde o río Ulla ata o Texo), segundo amosa o mapa de Koutsias et al. (2015) para o período 2000-2010.

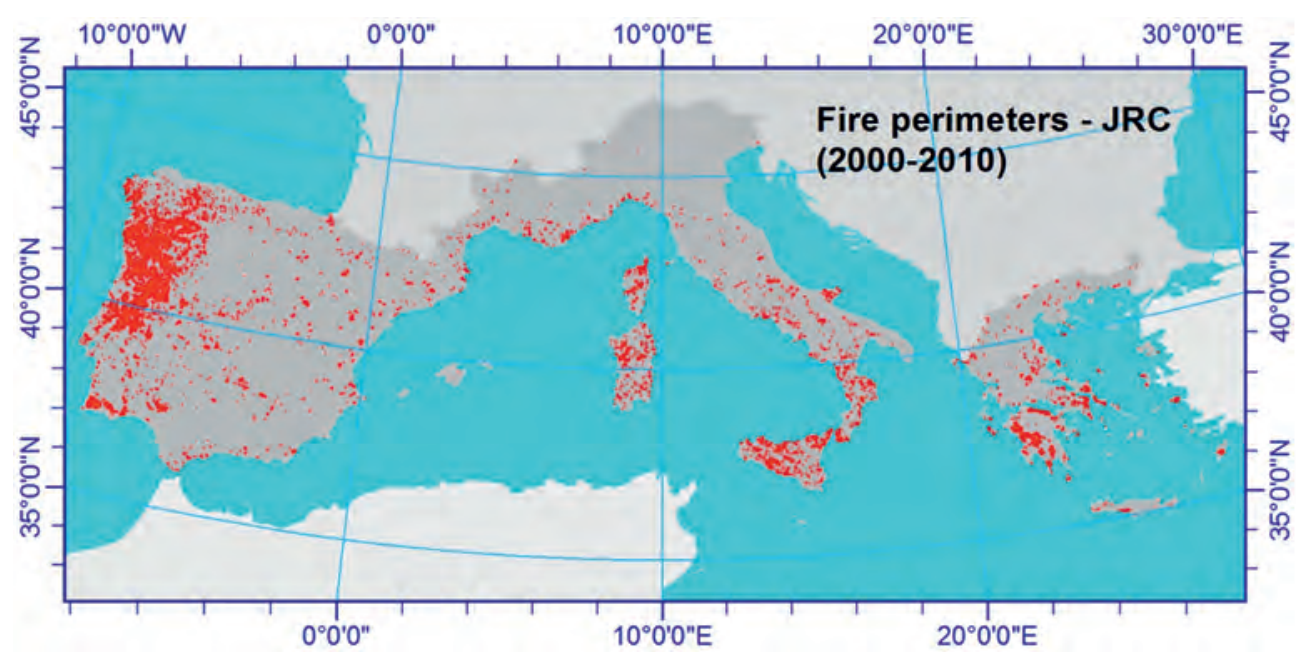

Figura 1. Incendios na cunca mediterránea (período 2000-2010) (Koutsias et al. 2015)

Tal singularidade do espazo atlántico-mediterráneo abondaría xa para considerar o interese e pertinencia de tentar describir unha historia común no relativo 
aos incendios forestais no que, por outra parte, ata o século XII foi un territorio compartido por un mesmo pobo e que, incluso despois desa data, seguiu a manter importantes similitudes xeográfico-sociais.

\section{PERÍODOS NA HISTORIA DO LUME}

Existen diferentes propostas para dividir a historia do uso do lume e dos incendios forestais na Terra. No caso que nos ocupa, e como marco temporal e conceptual deste traballo, consideraremos o esquema de Bowman et al. (2011), referido a toda a súa historia desde as orixes, hai centos de millóns de anos, ata a actualidade, e complementariamente a de Pausas e Keeley (2009), desde a modernidade, e a de Castellnou et al. (2007), desde 1950.

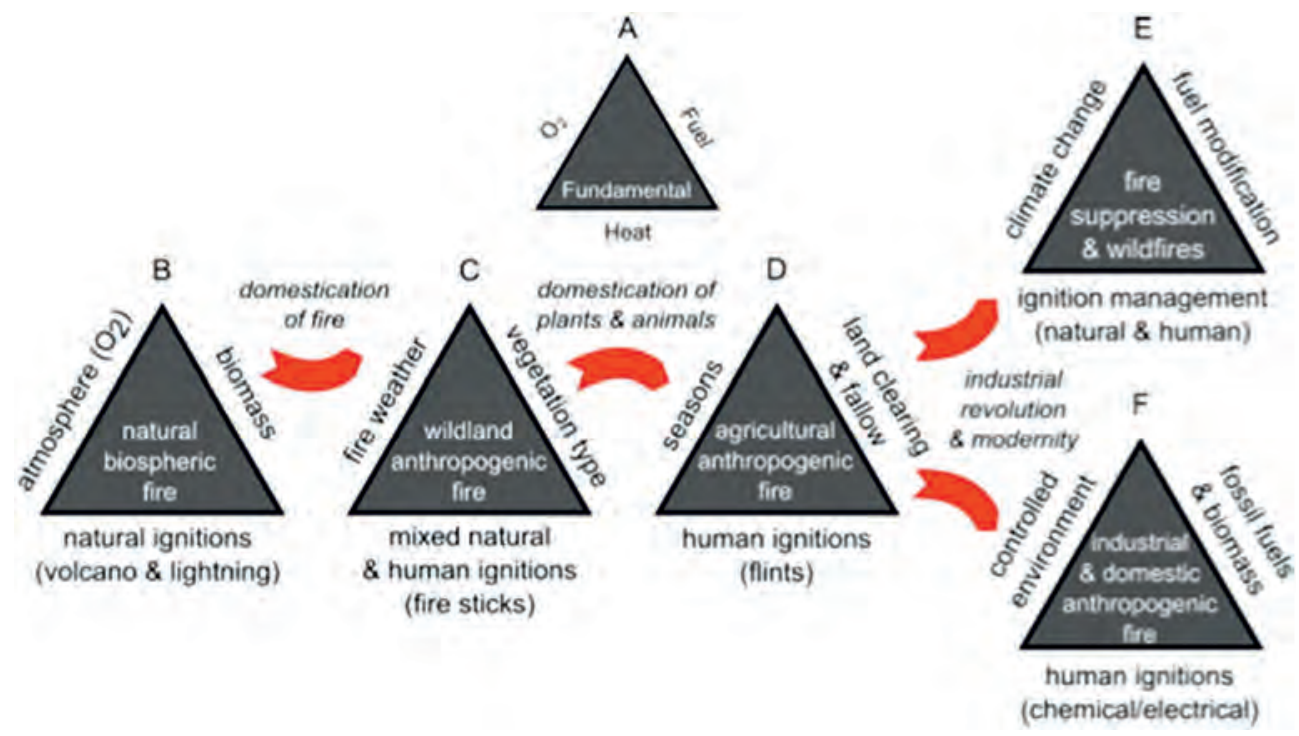

Figura 2. Fases píricas de Bowman et al. (2011)

De acordo cos primeiros autores, a orixe e posterior evolución dos lumes vai depender do que se define como «triángulo do lume» (esquema A na figura 2), no que interactúan tres factores: osíxeno, calor e combustible. Nos tempos pri- 
mixenios da historia da Terra, cunha atmosfera anóxica eran imposibles as combustións, polo que foi necesaria a chegada dos primeiros organismos fotosintetizadores (as algas e despois os vexetais) para que o osíxeno fixese a súa aparición. Posteriormente, coa colonización dos continentes emerxidos polos vexetais, apareceu o combustible como segundo elemento do triángulo, que en conxunción co osíxeno atmosférico é unha fonte de ignición natural, igual que podían ser os raios e os volcáns, os cales deron orixe xa aos primeiros incendios, os «incendios naturais biosféricos», tal como os define o esquema B da figura 2. Acontecía isto, de acordo cos últimos datos, no Silúrico, hai uns 400 millóns de anos.

A ubicua presenza de carbóns nos sedimentos desde esas datas amosa a importancia dos lumes naturais en canto factor importante da evolución dos ecosistemas; nalgúns casos - por exemplo, no do xénero Pinus e dalgunhas pradarías- actúan como axentes decisivos do seu éxito evolutivo e son responsables mesmo dalgúns dos seus caracteres máis salientables, que é o que sucede coa típica cortiza dos piñeiros.

A aparición dos primeiros homínidos en África hai 2,5 millóns de anos ${ }^{1}$ supuxo un cambio substancial no papel do lume na natureza, xa que estes novos primates comezaron a acoller, como unha das destrezas máis efectivas para a súa supervivencia, a do uso do lume. Existen evidencias desde hai 1,5 millóns de anos que amosan que o Homo erectus de África xa empezaba a ter un certo control sobre el e que, desde hai algo menos dun millón de anos ( 0,79 millóns), coas súas migracións xa era coñecido no Próximo Oriente, de onde posiblemente se expandiu cara a Europa (Pausas e Keeley 2009).

Durante o Paleolítico e o Mesolítico, cunha sociedade de cazadores-recolectores, o lume xa era utilizado para múltiples usos: clareo de matos e bosques co fin de facilitar os asentamentos, preparación dos alimentos, apertura de camiños, control de animais salvaxes prexudiciais, axuda para a caza, rexeneración de recursos alimenticios vexetais para homes e animais domésticos e mesmo como arma de guerra. Estaba a aparecer unha nova natureza na que a desaparición de

\footnotetext{
$1 \mathrm{Na}$ actualidade existen outras teorías que introducen certas novidades espazo-temporais na orixe de tales antecesores do home actual, pero neste traballo utilizaremos a que poderiamos cualificar como «teoría clásica».
} 
determinadas formacións vexetais polas queimas e a aparicións doutras máis adaptadas á convivencia co lume comezaban a definir unha paisaxe distinta. De acordo co esquema de Bowman et al. (figura 2), estaba a aparecer a fase pírica C de «lumes salvaxes antropoxénicos».

\section{OS PRIMEIROS AGRICULTORES DA IBERIA ATLÁNTICA}

O Neolítico define o paso de sociedades nómades de cazadores e recolectores a outras que, grazas ás técnicas agrarias, poden chegar a establecerse con máis ou menos persistencia nun determinado lugar. Estes pobos conseguiron, mediante as técnicas das rozas, estivadas ou arroteamentos, que aproveitaban a fertilidade que achegaban as cinzas dunha vexetación queimada previamente, que os cultivos de cereais puidesen manter unha pequena poboación asentada nun determinado lugar. No momento en que a fertilidade do solo se esgotaba polos sucesivos cultivos, había que practicar o mesmo sistema de queima e cultivo noutro lugar ata volver ao punto de partida, cando ao cabo de varios anos se recuperase a súa fertilidade, polo que estas prácticas tamén se denominaron de agricultura itinerante. Semella que o Neolítico naceu en Asia Menor hai uns 10000 anos e que desde alí se espallou en ondadas sucesivas cara ao resto dos pobos europeos, para chegar á Península Ibérica hai uns 6000 anos. A actividade agraria viuse acompañada, así mesmo, polo aproveitamento de pastos rexenerados polo lume ou de matos que, pola queima, daban orixe a brotes tenros para aproveitamento, nos dous casos, do gando ovino e vacún, polo que estas sociedades neolíticas deberían ser definidas realmente como de agricultores e pastores que, en calquera caso, tiñan sempre no lume a ferramenta básica de traballo. Esas actividades daban lugar, de xeito maioritario, a lumes controlados, que, de todas as maneiras, en situacións meteorolóxicas adversas derivarían en incendios de moi variables dimensións. Correspondería á fase pírica D: «lumes antropoxénicos agrícolas».

As técnicas que empregaban o lume para poñer en cultivo unha determinada zona de bosque foron descritas, a partir de experiencias en Dinamarca, por Iversen (1956) e foron denominadas «landnam» ou «ignicultura», ou, dun xeito máis popular, "cultivo mediante o lume» ou «cultivo en terra queimada», o cal, con diferentes variantes, chegou ata os nosos días como o modelo conceptual 
básico para explicar o aproveitamento do solo no Neolítico (Fábregas et al. 1997). O coñecemento actual da aplicación destas técnicas nun territorio determinado provén das análises de pole e doutros datos complementarios, tales que o estudo dos carbóns fósiles. Estes métodos permiten coñecer o impacto do lume sobre as formacións vexetais, nomeadamente sobre o bosque, e as diferentes etapas que seguen á súa destrución por el, así como identificar os diferentes cultivos e plantas acompañantes que presupoñen tamén o uso do fogo. En Galicia e Portugal existe na actualidade un número moi importante destas análises, que se sintetizarán seguindo as revisións de Fábregas et al. (1997) e Monteiro et al. (2006), con algunhas achegas puntuais de traballos máis recentes, como os de Carrión (2005) e Connor et al. (2012).

As primeiras evidencias de incendios no territorio galego-portugués son anteriores ao uso do lume para a agricultura, pois na serra da Estrela hai sinais claras de grandes áreas afectadas que deron orixe a importantes depósitos de carbóns sobre o 11400 ou 11300 BP (Connor et al. 2012) e nos montes do Buio e o Xistral, no contorno do $7500 \mathrm{BP}$, existen tamén testemuños fósiles de grandes incendios (Fábregas et al. 1997). Nestes casos habería que pensar que foron incendios descontrolados os que xeraron eses sinais paleobotánicos, porque a utilización do lume máis habitual naquela altura era só para pequenos clareos do bosque que facilitasen a caza e para tarefas domésticas. Nestas épocas había, sobre todo, un forte espallamento do bosque de quercíneas, que, en amplas zonas, cubría en masas mestas unha boa parte do país galego-portugués.

O pastoreo de gandos de ovino e vacún orixinou os seguintes sinais paleobotánicos de uso do lume. Este era aplicado na primavera para dar lugar despois a unha boa vexetación herbácea e mesmo, cando era mato o que se queimaba, para xerar gromos verdes comestibles. Na serra da Estrela, desde o $6400 \mathrm{BP}$, hai evidencias de incendios relacionados con esta economía, que rematou por asentarse nas serras portuguesas, dun xeito consolidado, polo 4000 BP. En Galicia, tal actividade está menos documentada, pero hai evidencias de comezos dela en Campo Lameiro sobre o $6300 \mathrm{BP}$ e de que se asenta xa dun xeito evidente sobre o 5500 ou 4000 (Carrión 2005) e se xeneraliza por todo o país no contorno do 4400 BP (Fábregas et al. 1997). Non é fácil calcular a extensión desta práctica do pastoreo, pero sería posible que na altura do 5000 ou 4000 BP unha boa parte das serras galegas e portuguesas estivesen xa deforestadas e cubertas por 
unha vexetación herbácea e que, como consecuencia das queimas sistemáticas a que eran sometidas, se orixinasen incendios descontrolados cando as condicións meteorolóxicas fosen adversas.

A práctica da ignicultura mediante rozas de ciclo longo ou curto (Boserup 1967) é probable que coincidise nos seus inicios coa economía pastoril, pois existen evidencias illadas de pole de cereal e plantas sinantrópicas en épocas tan adiantadas como o 6450 ou 6240 BP (Chan de Lamoso; Ramil-Rego et al. 1994), pero a súa consolidación non se deu ata o quinto milenio BP, no que se instala o sistema agropastoril e a propia agricultura se diversifica con outras especies, tales que a cebada, as leguminosas e o liño, que atendían a outras necesidades ademais das meramente alimentarias. Este cambio tamén se puido demostrar en xacementos arqueolóxicos e sedimentos do norte de Portugal (Fábregas et al. 1997). A súa xeneralización a todo o territorio galego-portugués deu orixe ao que Ramil-Rego (1992) denominou «estepa cultural», que situou no contorno temporal do $3700 \mathrm{BP}$.

A sedentarización definitiva das poboacións acaeceu no terceiro milenio BP coa cultura dos castros. $\mathrm{Na}$ volta destes asentamentos empezou a practicarse unha agricultura territorialmente estable grazas ás achegas en fertilizantes para o solo das dexeccións animais do gando doméstico que se ía incorporando á economía da familia ou do clan. Pero tamén o cultivo itinerante mediante as rozas continuou a ser un complemento indispensable que non só non se abandonou, senón que mesmo medrou e continuou co seu proceso deforestador, que nestas alturas estaba a espallar, en sucesión do bosque, un queirogal de Erica e Calluna que ademais comezaba a incluír, como especies pioneiras, leguminosas tales que Ulex.

No período romano e altomedieval, eses testemuños derivados das análises do pole e dos carbóns seguen a ser as referencias fundamentais dos efectos do lume, pois os documentos escritos que tratan destes temas son aínda moi escasos. Nos estudos citados da charca da Candieira e de Campo Lameiro apréciase un incremento importante da presión agropastoril, que leva practicamente á desaparición do bosque de Quercus e á súa substitución por queirogal de Erica, acompañado de leguminosas como Cistus ou Ulex, que son uns moi ben coñecidos colonizadores das terras queimadas e que mesmo chegan a desprazar as plantas herbáceas, que pasan a ser colonizadores secundarios do territorio. 


\begin{tabular}{|c|c|c|c|c|c|c|c|c|c|c|c|}
\hline Años B.P. & 8.000 & 7.500 & 7.000 & 6.500 & 6.000 & 5.500 & 5.000 & 4.500 & 4.000 & 3.500 & 3.000 \\
\hline Actividad Deforestadora & $\bullet$ & $\bullet \bullet$ & $\bullet$ & $\bullet$ & $\bullet$ & $\bullet \bullet$ & $\bullet \bullet$ & $\bullet \bullet$ & $\bullet$ & $\bullet$ & $\bullet \bullet \bullet \bullet \bullet$ \\
\hline \multicolumn{12}{|l|}{ RESTOS VEGETALES } \\
\hline Recolección de plantas & $\bullet$ & $\bullet$ & 0 & 0 & 0 & $\bullet$ & $\bullet$ & $\bullet$ & $\bullet$ & ๑е॰ & e0000 \\
\hline Polen de cereal y ruderales & & & & & & $\bullet$ & $\bullet$ & $\bullet$ & $\bullet$ & $\bullet \bullet$ & $\bullet \bullet$ \\
\hline Macrorrestos cultivos & & & & & & $\bullet$ & $\bullet$ & $\bullet$ & $\bullet$ & $\bullet \bullet$ & $\bullet \bullet \bullet \bullet \bullet$ \\
\hline \multicolumn{12}{|l|}{ RESTOS VEGETAIES } \\
\hline Animales domesticados & & & & & & 0 & $\bullet$ & $\bullet \bullet \bullet$ & $\bullet \bullet$ & $\bullet \bullet \bullet$ & $\bullet \bullet \bullet \bullet \bullet$ \\
\hline Caza & ○o & $\infty$ & $0 \bullet$ & $\infty$ & $\infty$ & 0 & $\bullet$ & $\bullet$ & $\bullet$ & $\bullet$ & $\bullet$ \\
\hline Pesca y marisqueo & & & $\bullet$ & 0 & 0 & 0 & $\bullet$ & $\bullet \bullet$ & $\bullet$ & $\bullet$ & $\bullet \bullet \bullet \bullet \bullet$ \\
\hline TUMULOS & & & & & & $\bullet \bullet$ & $\bullet$ & $\bullet \bullet$ & $\bullet \bullet$ & $\bullet$ & \\
\hline
\end{tabular}

Figura 3. Actividades relacionadas coa agricultura no Neolítico galego (Fábregas et al. 1997)

Como novidade importante en relación coas especies utilizadas nesta época teriamos o caso do castiñeiro, que, aínda que era coñecido de épocas anteriores, foi coa romanización cando iniciou o seu espallamento polo país galego-portugués en solos de non moi mala calidade, ao abrigo dos ventos e non moi afastados dos asentamentos de poboación. O centeo, coñecido tamén desde había moito tempo pero non utilizado como alimento, quizais pola cor escura da súa fariña, foi introducido e difundido polos pobos xermánicos, que estaban moi afeitos ao seu uso. $\mathrm{O}$ incremento da poboación e a boa adaptación do centeo aos solos máis pobres - por exemplo, os montesíos que sufriran xa varias queimasfixeron que fose adoptado sen moitos problemas como o cereal de elección para a ignicultura, segundo amosan con claridade os diagramas de pole da serra da Estrela.

Neste período, as queimas descontroladas do monte comezaban a ser moi frecuentes, de tal xeito que nun documento tan antigo como é o Fuero Juzgo (ano 634) se recollen as penas que debían aplicarse para aqueles que queimasen os montes intencionadamente ou por descoido, a cal é unha das primeiras referencias escritas relativas ao problema dos incendios forestais na Península Ibérica. 
LIBRO VIIL. TITVLO II.

dió. E si el sennor non quisiere fazer emienda por el siervo, dé el siervo 2 que lo descabecen.

II. De los omones que quemats monte.

$S_{i}$ algun omne enciende monte aieno , 6 arbores = de qual maibera quier, préndalo el iuez, é fagal dar $\mathrm{C}$. anotes , é faga emienda de lo que quermó, cuemo asmaren omnes buenos $E$ si el siervo lo fizo sin voluntad de so sennor, reciba C. é L. azotes, hy el sennor faga emienda por $\mathrm{e}$, si quisiere; é si non quisiere, hy el danno fuere dos tanto , 6 tres tanto que el siervo non vale, dé el siervo por el danno, é eea quito.
III. Do los que van s carrors, ef fou zen fuego.

Quien anda por camino', si s quiere fazex fuego en algun campo por corer ${ }^{\circ}$ de comer, 6 por se calentar, 6 por otra cosa, guśridese que el firego non vaya mes adelantre que fage nemiga? . E.si se prendiere en restrojo " 6 en peia seca, mátelo ', que non cresca 10 mas $\mathrm{E}$ si por ventura el fuego cresciene " mas, í quemare mies" $1 ", 6$ era, $\delta$ vina, $\delta$ casa, ó vergel, $\delta$ atca cosa, aquel que lo encendib, porque se non guardó, peche tanto quanto valia "s la cosa que quemó.

Figura 4. Fragmento do Fuero Juzgo (na versión da Real Academia Española do ano 1815) no que trata das penas para as persoas que queiman os montes

Normas semellantes que penalizan os que, activa ou pasivamente, desencadean incendios son recollidas en posteriores códigos, como o de Afonso X de 1253 e outros de tipo local, tales que o Foro de Santiago de 1252, que ditaba: "[Q]ue nenguen faga fuego para quemar los montes, et a los que fallaren faciendo, quel echen dentro» (Guitián L 1999).

Existen evidencias abondas de que desde o século VII ata o XIII houbo un período de crecemento da poboación que levou tamén a un espallamento das prácticas agrarias: as terras máis aptas para o cultivo foron aproveitadas case na súa totalidade e incluso resultou preciso recorrer ao monte como fonte de fertilidade delas, coas cortas periódicas de mato, e, así mesmo, acudir ás cada vez máis necesarias rozas de terreos que había que poñer temporalmente en cultivo (Villares 1980, Ferreira 2008). É posible que se tratase dun momento en que os incendios descontrolados tiveron unha renovada incidencia. O bosque retrocedeu neste período dun xeito moi evidente, ao que seguiu, en paralelo, unha forte expansión do mato (Martínez-Cortizas e Costa-Casais 2016). Esta foi a época que concluíu coa independencia política de Portugal.

Eses séculos de bonanza deron paso, a partir do século XIV, a un período de crise no que os recursos comezaron a rarear e as epidemias, entre elas a peste, fixeron a súa aparición. Tamén as guerras completaron o negro panorama: loitas 
civís en Portugal e Galicia, así como as fronteirizas contra mouros e casteláns, viñeron sumarse ás calamidades anteriores, de tal xeito que a poboación deixou de crecer e mesmo, en moitas zonas, retrocedeu. A partir de mediados do século XV sentíronse os primeiros sinais de recuperación: novos cultivos e novos xeitos de organizar o traballo agrícola, con rotacións que permitían o mantemento da fertilidade nas terras de labradío, e un espallamento da gandaría transhumante, todo o cal fixo posible que de novo a poboación empezase a aumentar. Estaban a darse os primeiros pasos cara á Idade Moderna.

\section{A IDADE MODERNA}

O fenómeno do urbanismo representou un feito moi característico desta época, xa que nela foi cando comezou a creación das principais cidades europeas. De todos os modos, na área galaico-portuguesa que nos ocupa tratouse dun proceso dunha certa debilidade, pois, agás no caso de Lisboa, que acadou os 100000 habitantes nos albores do XVI, o resto das cidades (Santiago, Pontevedra, Braga, Porto, Coimbra etc.) non chegaban, pola mesma altura, aos 10000 habitantes. De calquera forma, esta debilidade non impediu que se constituísen en focos dunha demanda importante de novos materiais, como o ferro e o vidro, que tiñan no carbón vexetal un produto imprescindible para a súa elaboración.

Os procesos de fabricación dese recurso, que eran xa coñecidos e practicados desde había varios séculos, acadaron un espallamento especial neste período, que só foi interrompido pola aparición e uso do carbón mineral nas primeiras décadas do XIX. Os carboeiros que proliferaron no contorno dos centros de demanda (cidades, ferrarías e obradoiros de vidro, entre outros) xeraron unha importante práctica deforestadora pola cantidade de madeira que precisaban e ademais foron orixe de incendios descontrolados, polo que, nas advertencias ou normas penais que regulamentaban o control do lume, foron considerados tamén a carón doutras actividades.

Máis importantes e frecuentes foron as advertencias cara a outras actividades, como eran o pastoreo e a decrúa de novos espazos para o cultivo, que, de resultas do importante crecemento demográfico que se acadou neste período (desde comezos do XVI ata finais do XVIII duplicouse a poboación de Galicia e Portugal), 


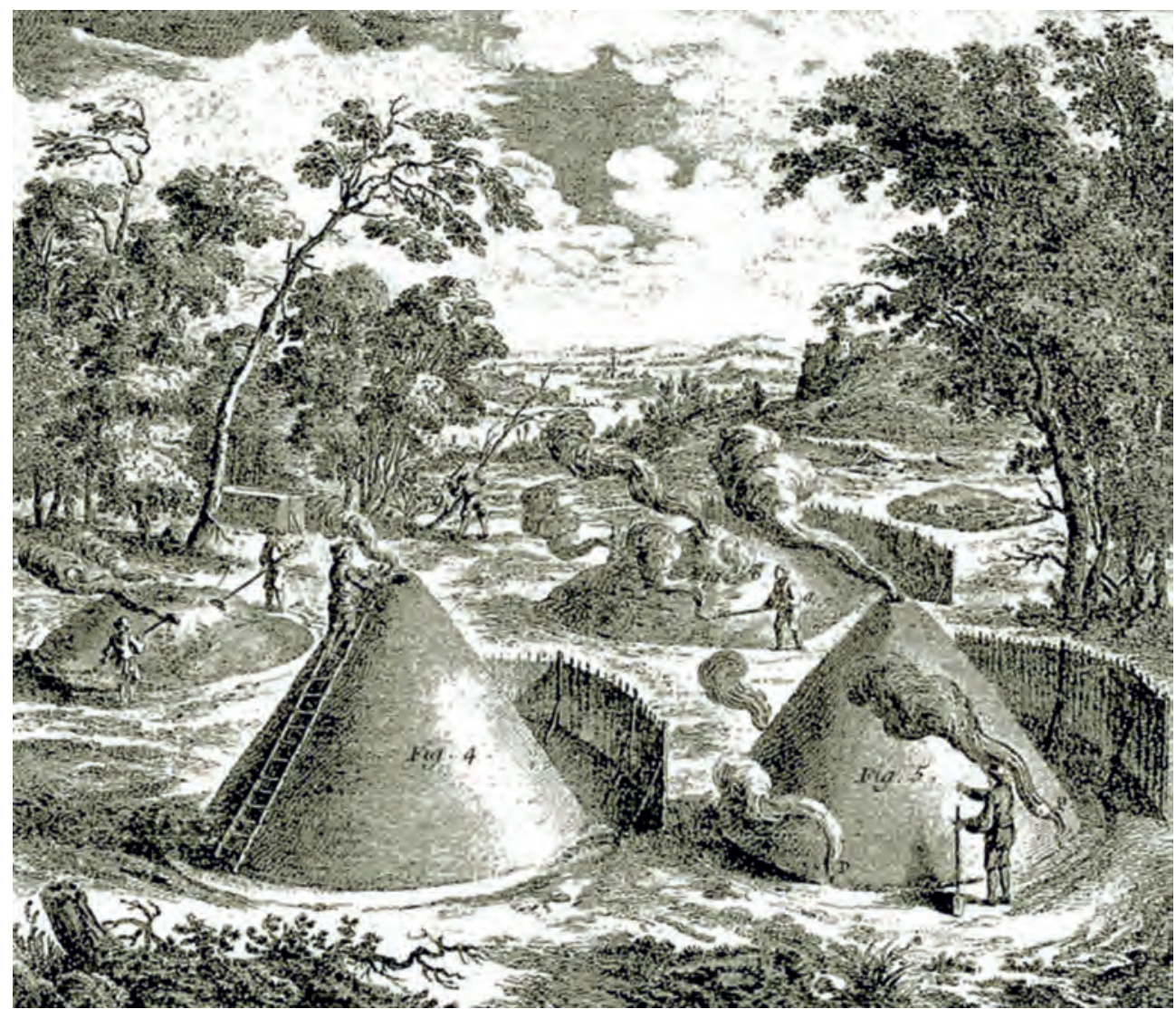

Figura 5. Carboeiros fabricando carbón vexetal (da Enciclopedia francesa)

foron, sen dúbida, as principais actividades xeradoras de incendios, os cales, cando as condicións meteorolóxicas non eran as axeitadas, polas secas e o vento, se propagaban por todo o país, tal como recolle unha crónica de Santiago do ano 1685: «[T] an secos fueron el verano y el estío de 1685, que se agotaron las fuentes y río; ardían los montes» (Fontana 1977).

$\mathrm{O}$ pastoreo nas zonas de monte incrementouse dun xeito importante polas necesidades de carne, leite e la que unha poboación en medra constante esixía, aínda que ao longo deste período se constatou un decrecemento dos efectivos gandeiros no monte. En xeral, tratábase dunha actividade que competía coa agricultura e a silvicultura e que na maioría dos casos, sobre todo cos grandes 
rabaños, era depositaria duns dereitos protexidos polo clero, os nobres e os mesmos monarcas. A práctica das queimas para rexenerar os pastos constituía a norma que ninguén dubidaba en aplicar e incluso, coas primeiras lexislacións sobre lumes, houbo unha certa permisividade que, co tempo e coa reiteración dos incendios que se xeraban, foi desaparecendo. Neste período, case todas as serras galaico-portuguesas estaban deforestadas e mesmo, bioloxicamente, moi degradadas polo pastoreo intensivo a que eran sometidas.

De todas as maneiras, a actividade á que se lle poden atribuír a maioría dos incendios da época foi a das novas decrúas do monte mediante o lume. Todas as lexislacións e normas que se foron redactando fan referencia a elas e, por outra parte, existe unha gran coincidencia entre os historiadores en afirmar que os rendementos dos cultivos por superficie medraron moi pouco neste período, polo que as necesarias achegas en cereais que se precisaban como alimento dunha poboación que ía en aumento só podían vir dunha ampliación da superficie cultivada. Dado que nesta altura as terras de vocación agrícola (vales e costas achanzadas por aterrazamentos) estaban xa practicamente ocupadas polos cultivos, a única ampliación posible era a partir de decrúas do monte sobre solos cada vez menos produtivos. Deste xeito, o risco de incendios ía espallándose polo monte en ondadas de cultivo itinerante cada vez máis amplas.

De resultas de que o lume fose afectando cunha frecuencia crecente a zonas en costa, a erosión do solo demostrou ser tamén unha consecuencia case inevitable dos lumes, que deixaban as súas pegadas máis evidentes na obstrución dos canais fluviais. Destes efectos hai testemuños tan antigos como as prohibicións da cidade de Coimbra de 1464 de facer fogos a menos de media legua das marxes do río (carta rexia de Afonso V), reiteradas en 1492 polo "grande dano que o campo da [súa] çidade de cojimbra Reçebe pelas mujtas áreas que nelle rrecreçem por causa dos mujtos fogos que se pooeem per as matas e charnecas arredor do Rio mondeguo». Máis adiante e xa en Galicia e Asturias no século XVII, as rías do Cantábrico experimentan un proceso acusado de perda de caudal que o marqués de Sargadelos atribúe en 1778 aos numerosos incendios que acontecen nos montes:

¿A qué parte arrojaremos la vista en que el fuego repetido de 6 en 6 años por una reprensible é inveterada costumbre no haya llevado á un punto final la desolación? $[\ldots]=[\ldots]$ 
Los bosques mas soverbios de roble, muy comunes antes de ahora en Asturias y Galicia, han desaparecido en la mayor parte, y en su lugar solo se miran montañas decepadas, valles talados, colinas debastadas [...]. = A estos perjuicios se siguen otros secundarios é inevitables. Las aguas que se forman de las lluvias, exemptas del embarazo de las espesuras y malezas [...], se despeñan y precipitan desde lo mas alto de las cumbres hasta lo mas profundo de los valles y de los rios, llevando lo mas precioso de la superficie hasta llegar al barro ó peña, y dexando el suelo reducido á erial [...]. = De aqui tiene origen el haberse visto en nuestros dias (ó quando mas desde el principio de este siglo) atollar muchos de los Puertos de mar casi inhabilitados para la navegacion mercantil.

(Casariego 1950)

A importancia que tanto en España como en Portugal foi adquirindo, a partir do século XVI, a construción de barcos para atender as necesidades cada vez máis urxentes dos seus amplos imperios coloniais causou que a madeira dos bosques se fose convertendo nun recurso estratéxico de interese nacional. Moitas masas forestais foron declaradas de «interese real» e pasaron a ser xestionadas pola Mariña, que ditou normas e dispuxo medios para a súa protección. Una nova silvicultura deu en nacer de mans destes técnicos, que non só tentaron protexer aqueles recursos, senón que, sobre todo, empezaron dun xeito sistemático a repoñer as masas forestais con repoboacións en novos plantíos.

Nos dous países, toda unha nova lexislación forestal comezou a xurdir con profusión e nela, con maior ou menor insistencia, a preocupación polo control dos lumes foi sempre un tema recorrente. De grande interese son as denominadas Ordenacións manuelinas (de Manuel I), nas que xa en 1521 se fai mención da necesidade de controlar o sotobosque como medida de prevención do lume: «[...] pelo facto dos pinhais não serem limpos do mato, seguem-se grandes inconvenientes de serem queimados» (Monteiro et al. 2006). Máis adiante o rei Filipe II (Filipe I de Portugal), que tiña un interese moi particular pola defensa das árbores e xardíns (Bauer 1980), volve insistir, nas denominadas Ordenacións filipinas (1603), nos perigos dos incendios forestais e na necesidade de que os veciños acudan por obriga ao seu control:

Defendemos, que nenhuma pessoa, de qualquer qualidade e condição que seja, ponha fogo em parte alguma, e pondo-se algum fogo em lugar, que possa seguir dano, os Juizes 
e Officiaes das Cidades, Villas e lugares, onde se taes fogos alevantarem, acudão e fação a elles acudir con muita diligencia, para prestes se haverem de apagar [...].

Descríbese despois toda unha sorte de medidas punitivas que ían desde a compensación de danos ata a deportación por dous anos en África (Monteiro et al. 2006).

Pódese sinalar igualmente que foi neste período cando comezou a expansión en Portugal do piñeiro bravo (Pinus pinaster), especie cunha especial proclividade ao lume e responsable, nalgunha medida, dos incendios forestais posteriores. Fronte á prioridade que lle outorgaba a lexislación española -por exemplo, en Galicia-á repoboación, nos plantíos da Mariña, coas especies eurosiberianas dos Quercus, no caso portugués foi o piñeiro bravo a especie de preferencia. O Pinhal do Rei de Leiria, de máis de 10000 hectáreas, iniciado no século XIII, nos tempos de Alfonso III, con plantacións de diferentes especies de piñeiro, a finais do século XV estaba fortemente degradado polos moitos incendios que o afectaron e as cortas fraudulentas a que fora sometido. Filipe II rexenerouno por completo, pero, neste caso, con plantacións exclusivas de piñeiro bravo, das que saíu unha boa parte das madeiras coas que foi construída a frota de navíos portuguesa. A partir do emblemático piñeiral semella que houbo unha importante difusión desta especie forestal; de todas as maneiras, non se pode desbotar que en moitas zonas do interior xurdisen plantacións resultantes da rexeneración de pequenos enclaves da dita especie, propia da historia forestal portuguesa. En Galicia, de acordo con Ruiz Zorrilla (1980), a penetración do piñeiro bravo puido comezar a finais do século XVII no Baixo Miño, procedente de Portugal.

Esta época remata tanto en Galicia como en Portugal co alento reformador da Ilustración, que achega formulacións racionalistas e sistemáticas sobre a problemática forestal. Aínda non existía a silvicultura en canto ciencia propia e ben definida, o que sería tarefa do século seguinte, pero xa os métodos de abordaxe da temática forestal se empezaron a facer cos novos coñecementos en economía e en ciencias naturais que a razón e o método fornecían. Para o territorio galego-portugués houbo dúas personalidades ilustradas que souberon encarar a problemática dos bosques, e nomeadamente o tema dos incendios, con este pensamento renovador: o político e mineraloxista brasileiro, profesor en Coimbra, José Bonifácio de Andrada e Silva, quen en 1803 foi nomeado Guarda-Mor de 
Bosques e Matas e que en 1815 publica o primeiro libro portugués sobre silvicultura, Memoria sobre a necessidade e utilidade do plantio de novos bosques em Portugal. Deseñou as novas repoboacións dos areais costeiros e, sobre todo, tiña unha formulación moi na liña humboldtiana da utilidade dos bosques na mellora das calidades do aire e das augas. Destacou con claridade os efectos negativos das deforestacións das encostas polo incremento da erosión e das cheas, sinalando «as queimas dos pastores» como unha das causas relevantes destes problemas.

O ilustrado Antonio Raimundo Ibáñez, marqués de Sargadelos, tiña unha preocupación permanente en relación coa necesidade de manter en condicións dunha axeitada explotación económica os bosques da mariña luguesa e asturiana. E, aínda que o carbón vexetal que precisaban as súas factorías era unha das causas importantes da deforestación, propoñía que o consumo de madeira que necesitaban fose compensado con novas plantacións, como a que realizou no contorno de Sargadelos, nun réxime de aproveitamento sostible. Escribiu sobre os danos dos incendios, aos que lles atribuía, segundo xa se comentou,

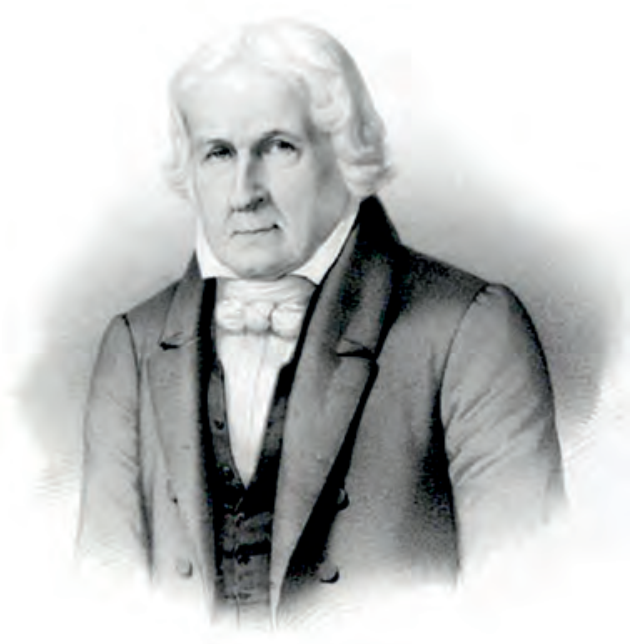

Figura 6. José Bonifácio de Andrada e Silva (1763-1838)

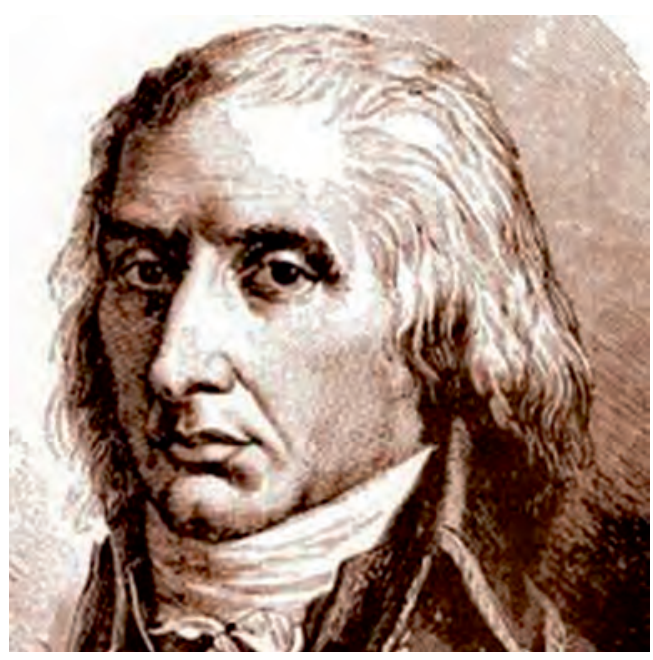

Figura 7. Antonio Raimundo Ibáñez, marqués de Sargadelos (1749-1809) 
graves problemas de erosión e arrastres cara ás rías, pero, sobre todo, clamou contra eles nos seus Discursos económico-politicos sobre la restauración de los montes y plantios en España (1802):

A pesar de la multitud de enemigos que por todas partes asaltan a nuestros montes, nunca hubieran llegado al estado deplorable y lastimoso a que se hallan reducidos si la legislación desde un principio se hubiera esforzado a desterrar los incendios. No es posible dar una idea cabal de los males que han causado.

[...] las aguas de las riadas que suceden a las quemas, libres de los estorbos de las malezas que antes detenían, se precipitan con violencia, arrastran y llevan consigo las cenizas y todo lo que es movible hasta llegar al barro y a la peña.

[...] El fuego abrasa y devora en un día el bien gratuito que a la naturaleza le costó muchos siglos. Se puede decir que entre todos los desórdenes es el enemigo más temible y destructor de los montes.

[...] A cualquier parte que miremos no se ven sino colinas abrasadas, montañas desnudas, cañadas y quebraduras devastadas, comunes y baldíos pelados, y tal o cual reliquia de algunos bosques feraces que pugnan todavía por conservarse.

\section{O BOSQUE E OS INCENDIOS NA ERA DAS TÉCNICAS}

Seguindo co esquema de Bowman et al. (2011), agora entrariamos nas etapas E e F, correspondentes á Revolución Industrial e a modernidade. Esta nova etapa podería coincidir, desde o punto de vista dos incendios forestais, co cambio de «fase» antropoxénica que propoñían Pausas e Keeley (2009) sobre unha idea anterior de Guyette et al. (2012). De acordo con estes autores, arredor de $1850^{2}$ prodúcese un cambio dos incendios que cualifican de «dependentes da ignición» cara aos «limitados polo combustible» (Guyette et al. 2012) ou "controlados polo combustible» (Pausas e Keeley 2009). No primeiro caso serían fundamentalmente as actividades antropoxénicas e, como referentes delas, a densidade da poboación rural ou a superficie agraria as determinantes dos incendios, mentres

\footnotetext{
2 Esta data refírese á experiencia americana, na que se basearon Guyette et al. (2012), pero apuntan que pode variar duns países a outros.
} 
que no segundo caso, acadado xa o teito da expansión da poboación, sería o amoreamento e manexo do combustible a súa causa fundamental.

De todas as maneiras, estimamos máis acaído utilizar, para definir esta nova época dominada pola industrialización e a técnica, a división establecida por Monteiro et al. (2006) sobre a importancia que ten nesa etapa a chegada dos novos técnicos forestais saídos do ensino superior, grazas aos que, "pela primeira vez, vamos encontrar, entre nós, expressões de verdadeiro carácter técnico a respeito de ideias ou conceitos sobre combate ou defesa contra incêndios florestais, não a simples constatação dos riscos e das punições [...]». Antes poderiamos estar a falar de afeccionados máis ou menos acertados; agora xa estariamos diante de verdadeiros técnicos silvicultores.

En Portugal, antes da creación dos primeiros cursos superiores de ensino silvícola, habería que destacar o alemán Friderico L. G. de Varnhagen, que foi nomeado Administrador Geral das Matas e é autor dun fundamental Manual de Instruçôes práticas sobre a sementeira, cultura e cortes dos Pinheiros (1836), no que aparece, citado con gran precocidade, o interese que ten para o bosque a realización de fogos controlados fóra da época de incendios como «un meio seguro de libra-lo de ser incendiado no verão». Tamén se lle debe a que foi posiblemente a primeira rede de devasas de prevención de incendios construída na Península, que foi comezada en 1826 a partir dunha densa malla ortogonal delas de 10 e 20 metros de ancho.

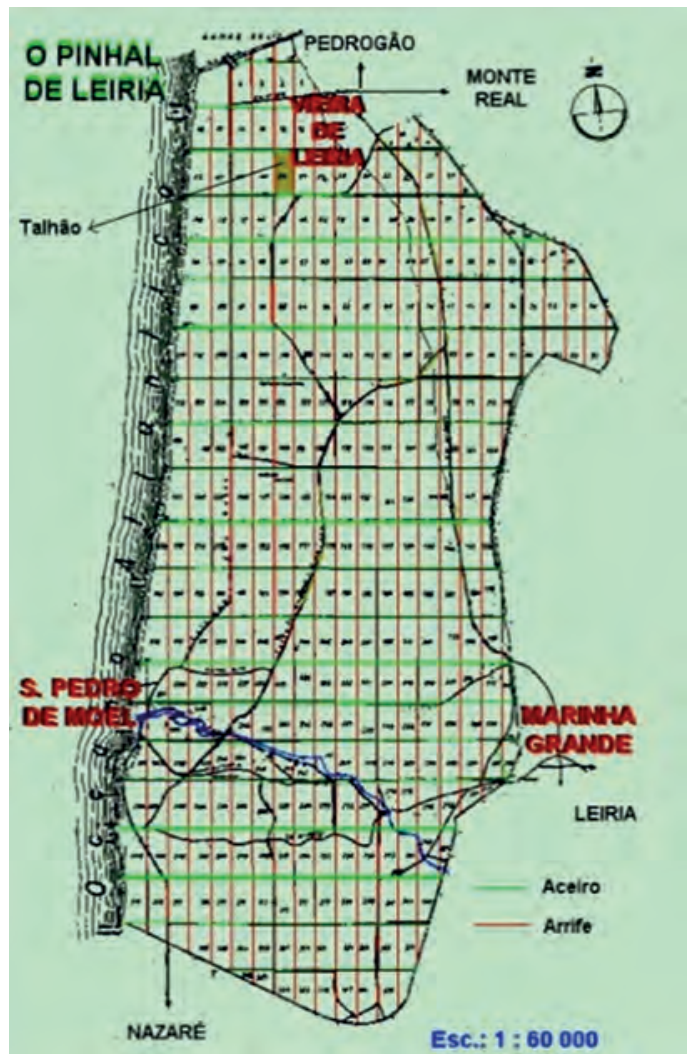

Figura 8. Rede de devasas do Pinhal de Leiria 


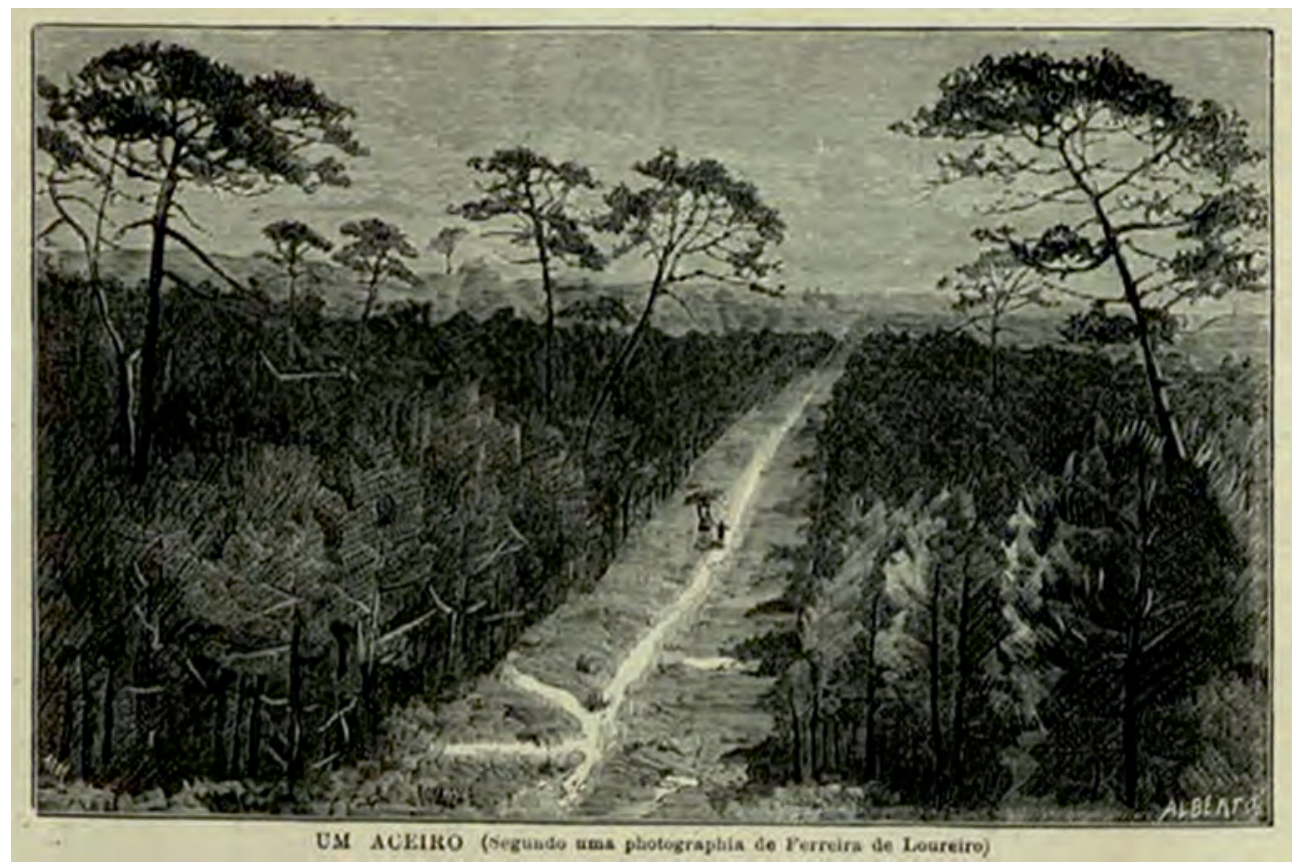

Figura 9. Devasa (aceiro) no Pinhal do Rei en Leiria (1909)

Os primeiros forestais portugueses con estudos superiores saíron en 1864 do Curso Superior de Silvicultura do Instituto Geral de Agricultura do Porto. Antes, algúns técnicos forestais portugueses tiveran unha boa formación silvícola en Alemaña, nomeadamente na Academia de Tharandt, fundada e dirixida polo pai da dasonomía, Heinrich Cotta.

En España, inspirada nestes mesmos principios científicos da silvicultura alemá, foi creada en 1846 a Escola Superior de Enxeñeiros de Montes, de onde saíron os primeiros técnicos forestais, que fixeron a súa chegada a Galicia en 1859. Antes, como acontecera en Portugal, falaron do monte e dos seus problemas «afeccionados» tales que o médico Gil Rey e o naturalista Valenzuela (Díaz-Fierros 2006). Como consecuencia de que a formación técnica dos primeiros forestais españois e portugueses bebese nas mesmas fontes, poderíase dicir que estaba inspirada polo que se denominou o «naturalismo forestal», imbuído do pensamento humboldtiano, que tiña como idea central a do equilibro e harmonía da natureza (Casals 1988). 
O comezo desta época coincide tamén, posiblemente, coa superficie mínima acadada polo espazo forestal (entre o $10 \%$ e o $15 \%$ da superficie total) e os inicios da repunta do proceso reforestador mediante repoboacións que caracterizou todo o século XIX e boa parte do XX. Este mínimo conseguiríase antes en Portugal (quizais a mediados do XVIII) e, polo tanto, o proceso repoboador foi, de igual modo, máis precoz que en Galicia. En calquera caso, o que resulta evidente é que todos os incesantes desvelos da Administración da Mariña, desde o século XVI, para establecer plantíos que fornecesen de madeiras os seus estaleiros remataron nun sonoro fracaso. Así mesmo, toda a reconquista do espazo forestal que se deu a partir deste momento tivo como protagonista principal o piñeiro bravo, que, desde o seu recanto tradicional de Leiria, podería dicirse que chegou a dominar, nun proceso que durou ata a metade do século XX, a maior parte do territorio forestal galego-portugués. Os datos correspondentes ás superficies dedicadas ao piñeiro bravo en Galicia e Portugal son os recollidos na táboa I.

Táboa I. Evolución das superficies (en hectáreas) dedicadas ao Pinus pinaster en Portugal e Galicia

\begin{tabular}{|l|l|l|}
\hline & Portugal & Galicia \\
\hline 1752 & 15000 & 240 \\
\hline 1859 & & 6689 \\
\hline 1875 & 210000 & \\
\hline $1902-1903$ & $430000-913000$ & \\
\hline 1928 & 1131500 & \\
\hline 1947 & & 300000 \\
\hline 1959 & & 500000 \\
\hline 1966 & 1287000 & \\
\hline $1972-1973$ & & 616000 \\
\hline
\end{tabular}

Datos de Ruiz Zorrilla (1980), Devy-Vareta (1999), Beiras (1967) e Molina (1979). Os datos galegos dos inventarios de 1947 e 1959 son os calculados a partir dos valores correspondentes ás categorías «P. pinaster» $\mathrm{e}$ «mesturas»

No territorio galego-portugués pódese demostrar que tamén, máis ou menos na primeira metade do século XIX, se chega case aos máximos da expansión 
territorial do mundo rural e que a partir de agora a medra da poboación, aínda que vai seguir progresando ata as primeiras décadas do XX, se vai sustentar sobre todo no crecemento de vilas e cidades. Estas, pola súa vez, absorberán os excedentes da poboación rural que non teñan recursos para subsistiren, nun proceso xa imparable de emigración campo-cidade que se complementará, no último terzo do XIX, cun forte incremento da emigración cara a América.

Esta poboación asentada no rural, a pesar do forte aumento das rozas que se provocou no devandito período, desenvolverá, ao mesmo tempo, un eficaz proceso de control do combustible, centrado maiormente no mato de Ulex, a partir de actividades tales que a recolección do estrume para fertilizante das terras (Bouhier calcula que se utilizaba como mínimo unha superficie de mato dobre da que tiñan as terras de labradío, polo que, segundo a súa xa clásica sentenza, «o monte era o soporte dos cultivos»), fonte de calor, alimentación do gando, protección de camiños etc.

Pese ao antedito control do combustible, esta época vai coñecer un incremento dos incendios utilizados en forma de protesta do campesiñado fronte aos drásticos cambios que se van producir tanto en España como en Portugal en relación coa titularidade e uso do monte, sobre todo a partir dos procesos de desamortización e os intentos de estatalización dos sistemas comunais e tradicionais de aproveitamento deste espazo. A irrupción dos réximes autoritarios do Estado Novo e do franquismo, cos seus métodos expeditivos de apropiación do uso do monte, radicalizou as posturas e as respostas do campesiñado.

Eses incendios de carácter sociopolítico víronse acompañados dos xa clásicos fogos descontrolados xerados polo pastoreo e a agricultura de rozas, así como polas queimas de restroballos. E tamén apareceu algunha forma nova de incendios: por exemplo, a dos lumes derivados das actividades excursionistas, en medra crecente sobre todo no contorno das cidades (Díaz-Fierros 2006). De igual modo, pódese sinalar como característico deste período que a prensa comece xa a facerse eco dos casos máis salientables e que apareza unha literatura máis ou menos impregnada do pensamento rexeneracionista, maiormente de Costa (entre os exemplos españois poderíanse citar La locura de los pastores [1910], de Federico Rahola; La canción del Duero [1919], de Julio Senador; Murmullos de la selva [1923], de Ignacio Elorrieta, e El riesgo de los incendios en los montes [1927], de Antonio Lleó). 
En Portugal foi moi sinalada a reportaxe da Ilustração Portuguesa (suplemento de $O$ Século do 4 de setembro de 1916) sobre un grande incendio do Pinhal de Leiria, na que se amosaba, no contexto da literatura dramática que suxería, unha visión realista do incendio:

As chamas rebentaram em três pontos ao mesmo tempo. Tocadas pelo vento e alimentadas pelo mato miúdo e pela caruma seca que cobriam o solo, não tardaram a cruzar-se num grande mar de fogo. Una coisa sublimemente horrível!

Buzinas, apitos, toques de sino, gritaria, alvoroçaram as povoaçōes convizinhas, das quais a principal é a vila da Marinha Grande. Nas fábricas, nos campos, em casa não ficou ninguém. Todos munidos de enxadas, machados, pás, forquilhas, ancinhos, do primeiro instrumento que topavam à mão, abalaram desordenadamente para atacar o fogo [...].

E, sobre todo, unha descrición detallada do combate contra o fogo que paga a pena coñecer cun certo vagar:

$\mathrm{Na}$ fúria com que toda a gente se atirava ao fogo não havia visivelmente um plano de ataque, executando a uma voz imperiosa de comando; mas havia uma perícia e uma tática individuais que davam ao conjunto dos esforços uma admirável unidade de ação. Abrem-se aceiros, compridos e largos, machadando sem piedade belas árvores para atalhar a marcha galopante do fogo, que as devoraria, a elas e a muitas mais, sendo admirável como essa gente se estendia numa linha rigorosa de combate, sen se estorvar uma à outra.

$[\ldots]$

[...] [C]ontinuavam a manejar o machado [...]. Outros roçavam o mato e procuravam arredá-lo do caminho do fogo; estes deitaban pás de terra sobre a vegetação miúda para o abafar; aqueles abriam arrifes à enxada tentando atalhar-lhe a marcha de todas as formas possíveis.

Pero quizais o máis sobresaínte sería o xeito en que se estaba a utilizar xa unha técnica tan innovadora naquela altura como a do contrafogo:

[...] [A] fase culminante da batalha é o contrafogo. Abre-se um aceiro largo. Lança-se lumo, bem entendido [...]. 
[...]

Segue-se então brusco um silêncio de morte. Se o mar encrespado, bramindo furioso, se estagnasse de súbito num lago dormente, não nos chocaria mais brutal impressão de contraste. Até o vento se acalmou. A forte exclamação de vitória...

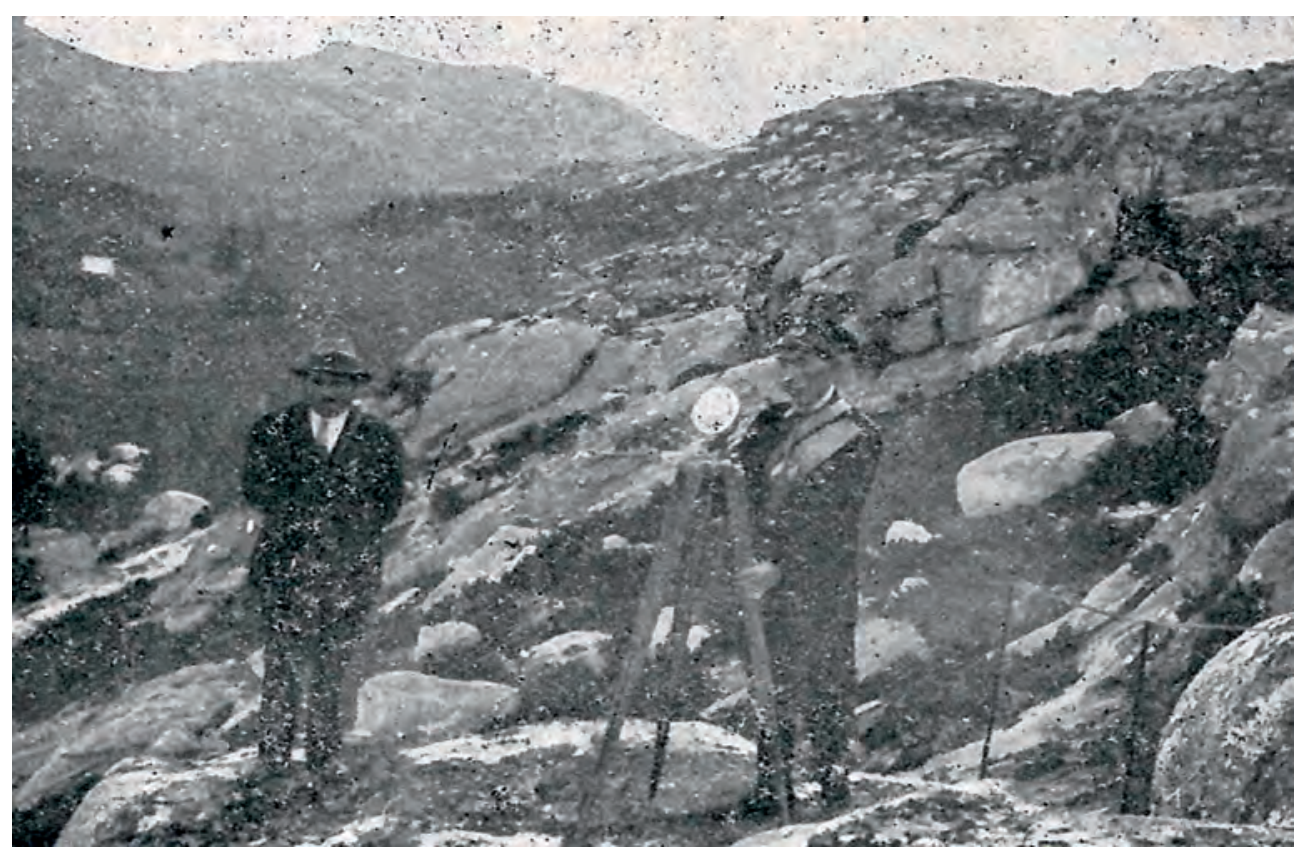

Figura 10. Garda forestal transmitindo información mediante un heliógrafo sobre un incendio en Oia (Galicia) (Areses 1929)

Estas descricións do incendio de Leiria, onde aparecen os contrafogos, sumadas ás técnicas de creación de devasas coñecidas e practicadas desde bastantes anos antes, sitúannos xa diante das novas técnicas que se estaban a desenvolver na loita contra os incendios forestais. Ao tempo, outras novidades técnicas, como a transmisión de sinais a distancia co heliógrafo e, posteriormente, coa telefonía, contribúen a que os avisos e a coordinación poidan realizarse en períodos máis curtos.

Por outra parte, todos os plans de repoboación que se poñen en marcha levan incorporadas medidas moi explícitas sobre o control na prevención e extinción 
dos incendios, e está xeneralizada a práctica, neste último caso, da obrigatoriedade de os veciños acudiren sempre que os servizos forestais e a forza pública o demandasen, segundo describe Areses (1929) no seu libro:

Al notar la presencia del fuego, deberán los pedáneos avisar a los vecinos, dando señales de alarma por medio de bocinas, campanas, etc. Provistas las gentes de azadas y ramaje de los árboles que se encuentren al paso, se pondrán a las órdenes del Guarda Forestal, de la Guardia Civil o en su ausencia, de personas capacitadas para asumir la dirección de los trabajos de extinción. Se distribuirá la gente rápidamente a lo largo de la línea de fuego, procurando que quede a sus espaldas un camino, no solo para asegurar la retirada, sino por la mayor facilidad para moverse y detener el fuego. Mientras unos azotan las llamas con el ramaje, los otros manejarán la azada para arrojar tierra y abrir cortafuegos o zanjas cuando el fuego sea subterráneo.

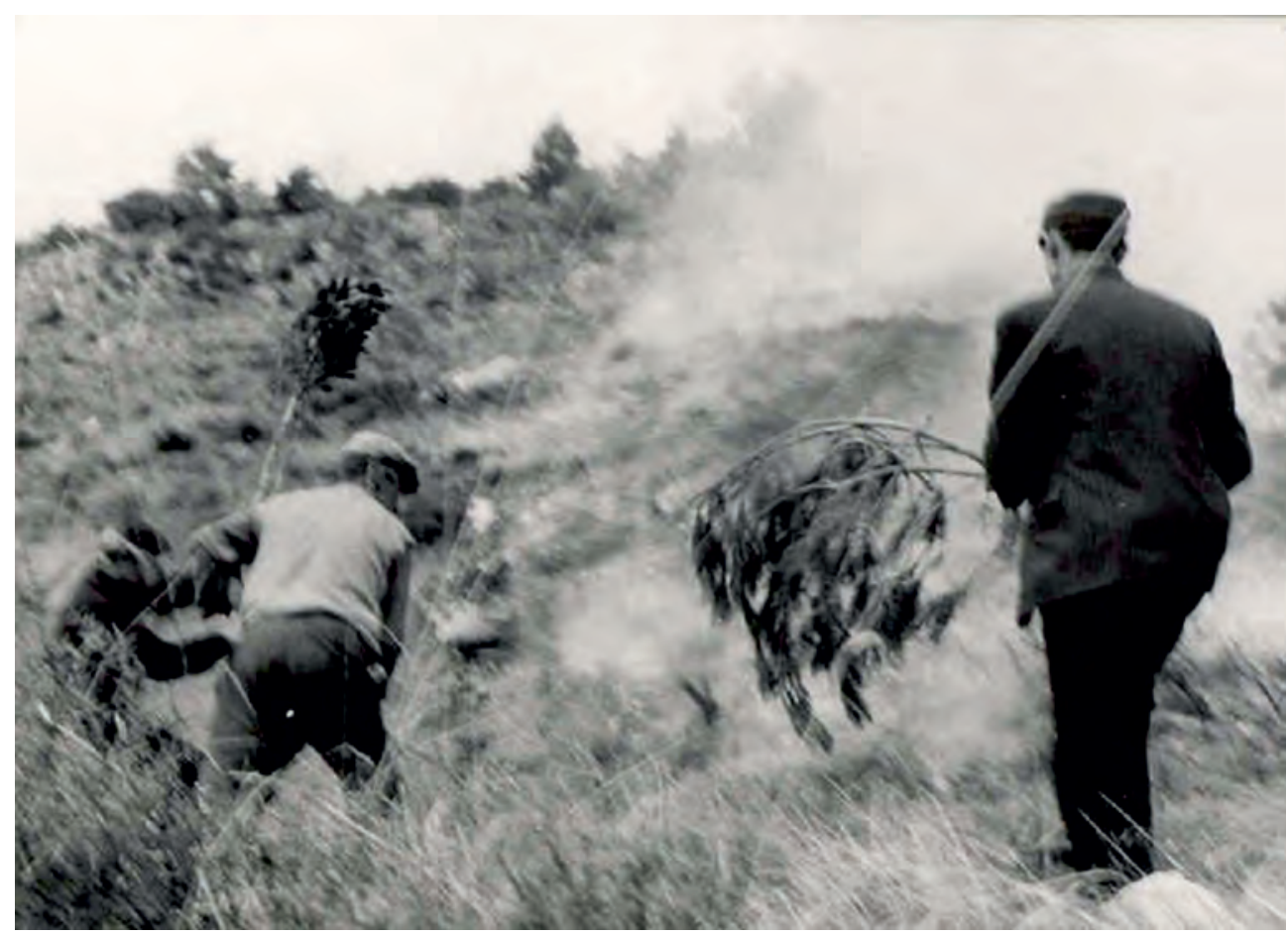

Figura 11. Extinción de incendios forestais con métodos tradicionais (Vélez 2015) 
Foi unha época en que, aínda que as novas repoboacións forestais ocupaban xa amplos espazos do territorio galego-portugués en masas, en moitos casos compactas de máis, os incendios, grazas ao control do mato polos agricultores, poucas veces superaban individualmente o centenar de hectáreas e o cómputo anual en raras ocasións excedía as 5000 .

\section{O DESARTELLAMENTO DO MUNDO RURAL. DOS SESENTA EN DIANTE}

Os procesos de desenvolvemento económico que se inician nos dous países a partir dos anos sesenta, xunto co atractivo da florecente Europa como destino das poboacións empobrecidas das áreas de montaña, entre outras razóns, xeraron un fluxo imparable de abandono do campo dos recursos humanos máis activos. En Galicia, entre 1960 e finais dos oitenta os ocupados agrarios pasaron de 660000 a 330000 e nos principios do século XXI xa se estaba nos 110000 . En Portugal, a poboación activa agraria pasou de millón e medio de traballadores en 1950 a un terzo menos en 1970 e algo menos da metade en 1981.

Este éxodo masivo motivou que as prácticas tradicionais de control do mato que estaban a actuar desde tempos inmemoriais no monte deixasen de levarse a cabo e comezase o amoreamento de combustible nesas zonas. E resulta sintomático que, ao remate de menos de dez anos, cando a acumulación de biomasa acadou niveis importantes e as condicións meteorolóxicas non foron as axeitadas, se iniciase a progresión dos incendios, que superaron a barreira das 20000 ha anuais queimadas no ano 1968 en Portugal e no 1972 en Galicia. Despois empezou unha tendencia crecente na que se excederon as 100000 ha en Portugal no ano 1975 e en Galicia no 1978. Ao tempo, o número de sinistros en Galicia xa superara os 6000, mentres que en Portugal estaban aínda por baixo dos 500. De todas as maneiras, este reducido número de ocorrencias agachaba a contrapartida dalgúns megaincendios que aconteceran naquela altura, como o de Vale do Rei (1961), de 2500 ha; Viana (1962), 5000; Sintra (1966), 5000; Vila de Rei (1980), 12000, e Arganil (1981), con 10900 ha (Ferreira-Leite et al. 2013). Esta particularidade portuguesa estaba a indicar, posiblemente, que as masas combustibles -árbores e mato- tiñan unha maior continuidade que no 

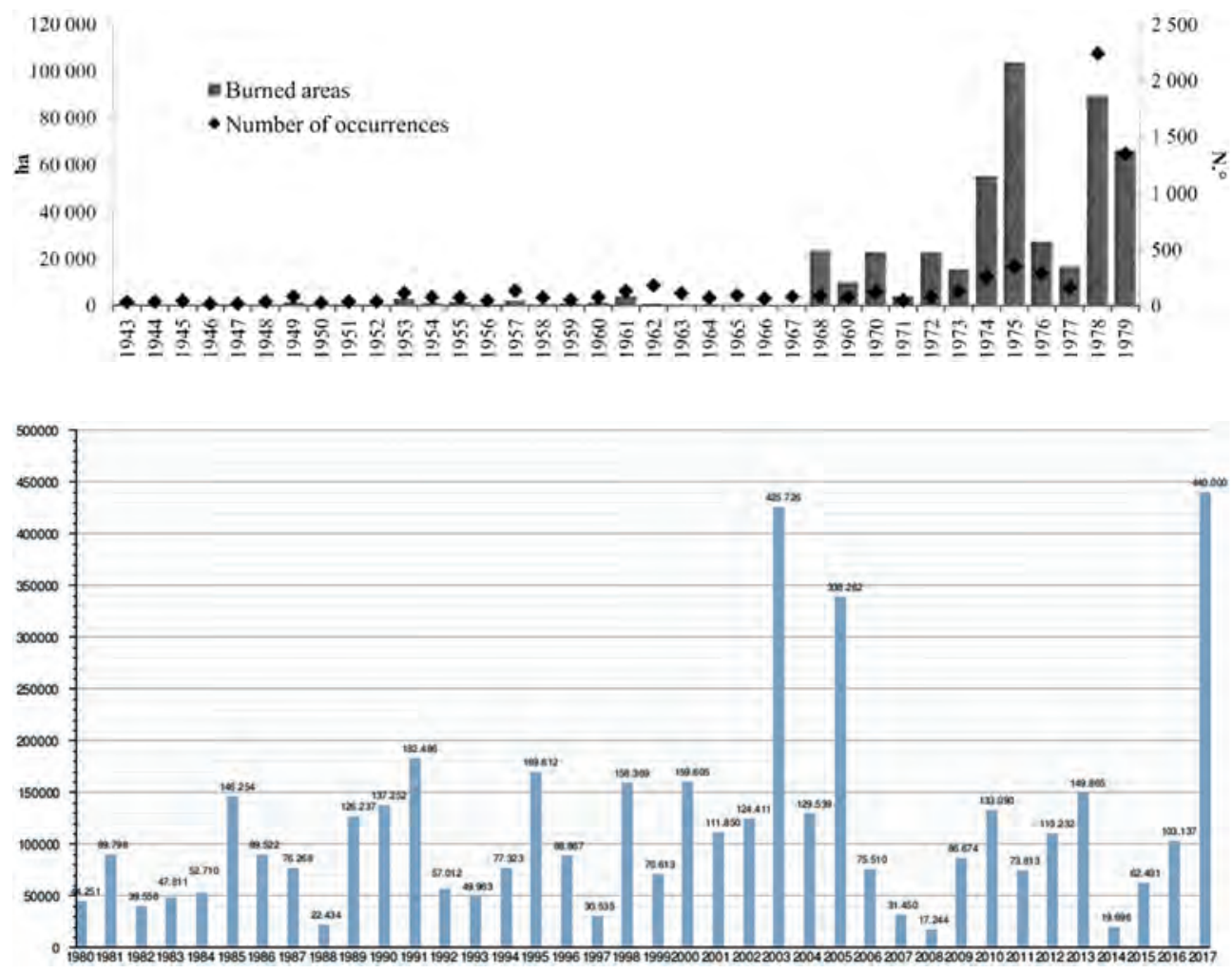

Figura 12. Incendios forestais en Portugal (1943-2017)

caso galego, onde a fragmentación da propiedade daba orixe a unha paisaxe moito máis promiscua e minifundista e, como consecuencia, a incendios individuais menores.

Os anos oitenta caracterízanse por un recruar da onda incendiaria, na que Galicia supera de novo, por tres veces, a barreira das 100000 ha anuais (en 1981, 1985 e, sobre todo, en 1989, co máximo ata agora acadado das 205000 ha). En Portugal, igualmente se supera en tres ocasións a barreira das 100000 e, como dato principal, o número de incendios sitúase xa por enriba dos 5000. A década dos noventa, co importante incremento que experimentan os medios de extinción en Galicia (chegan a multiplicarse por cinco os orzamentos), trae como consecuencia que a superficie queimada se reduza drasticamente, con valores, en 


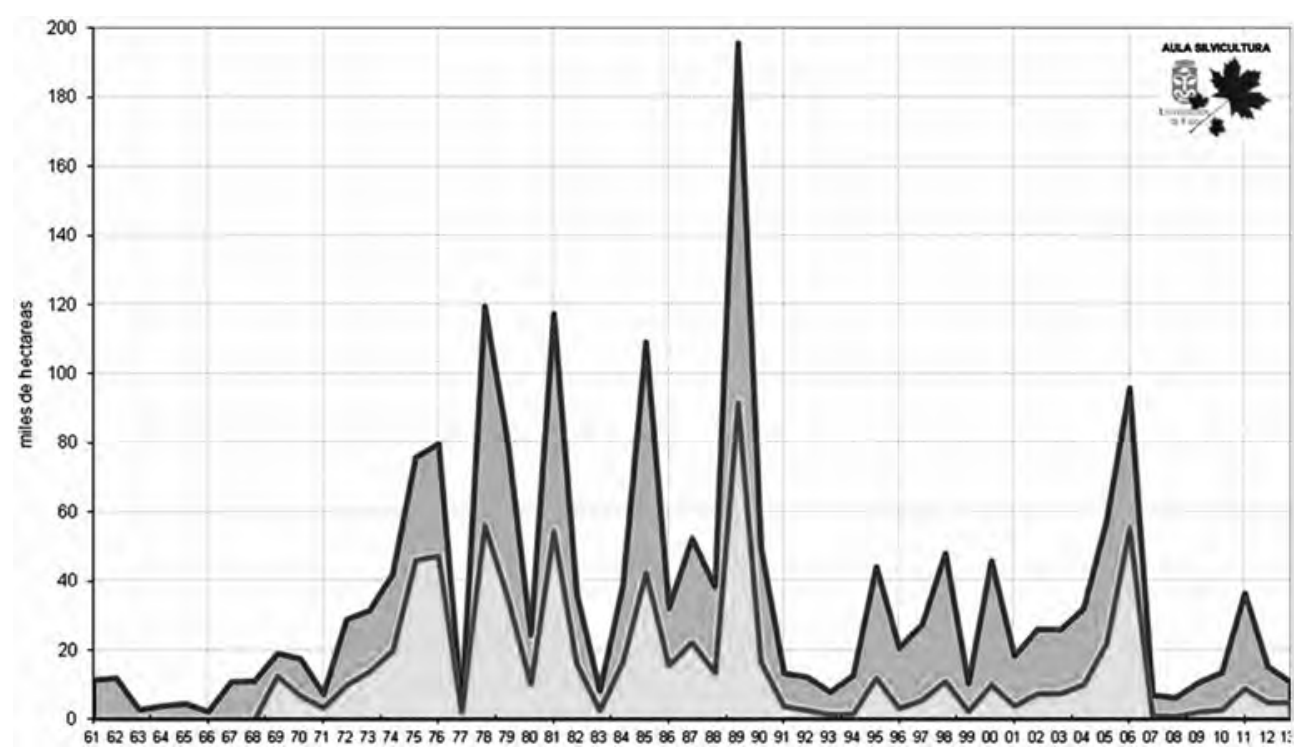

Figura 13. Evolución da superficie queimada en Galicia (1961-2013)

xeral, por baixo das 20000 ha anuais, agás algúns anos en que, polas adversas condicións meteorolóxicas $(1995,1998$ e 2000) se achega ás 50000 ha. En Portugal, en cambio, non hai inversión na tendencia, con catro anos por enriba das 100000 ha e manténdose moi elevado, así mesmo, o número de sinistros (entre 15000 e 30000$)$.

Co novo século a tendencia de fondo mantense, en Galicia sobre as 20000 ou 30000 ha e en Portugal sobre as 50000 ou 100000 , con anos excepcionais como o 2006, para Galicia, con 60000 ha, e para Portugal o 2003, con máis de 426000 , e o 2005, con 340000 ha. Finalmente, o ano 2017 foi tráxico para os dous países, con 440000 ha queimadas en Portugal e máis de 50000 en Galicia e cun balance de varias decenas de mortos.

Como consecuencia dese espectacular incremento dos incendios e acorde coa importancia que os factores técnicos foron acadando nestes tempos, os medios de extinción tamén foron evolucionando con rapidez. Dos métodos rudimentarios e predominantemente manuais que existían antes dos sesenta, pasouse en poucas décadas a dispor dun impresionante arsenal de dispositivos técnicos e de coordinación, xunto cuns orzamentos de decenas de millóns de euros. 
En España, os primeiros cambios viñeron da man das axudas estadounidenses como contrapartida da instalación das bases militares, que permitiron a compra de varios camións motobombas (en 1968 dispoñíase xa de 216 unidades) e, sobre todo, da primeira aeronave contraincendios, un Canadiar CL-215 que se probou en Galicia no ano 1969. En 1980 comeza a utilización dos helicópteros para desprazamento das brigadas aerotransportables, así como os primeiros ensaios de aplicacións do lume prescrito. $\mathrm{Na}$ década seguinte aparecen os sensores remotos para detección de incendios e, principalmente, a revolución informática en referencia ao tratamento e procesamento de datos. A coordinación entre os recursos das comunidades autónomas e do Estado, que ao inicio xerou bastantes problemas, axiña foi encamiñada coa integración dos diferentes servizos en unidades de mando único. A creación no 2005 da Unidade Militar de Emerxencias (UME) dentro das forzas armadas supuxo a dispoñibilidade de elementos humanos dotados de axeitada preparación técnica e facilidades para o seu desprazamento e integración nos operativos de extinción. Por último, o problema da erosión dos solos como consecuencia dos incendios, que foi formulado cientificamente a finais dos oitenta, a partir do ano 2015 deu orixe a medidas innovadoras de control postincendio. Galicia, en todas estas accións, con amplos recursos e medios e un persoal ben curtido na loita e prevención contra os incendios, constitúe na actualidade unha referencia dentro do Estado e mesmo da área mediterránea.

En Portugal, na década dos sesenta e no marco da loita contra o fogo, que dependía fundamentalmente dos servicios forestais, establecéronse uns Princípios Básicos de Luta contra Incêndios (redactados por Quintanilha, Silva e Moreira da Silva), que sentaban as normas dun operativo moderno e actualizado de extinción e prevención, pero a escaseza de medios e, sobre todo, o marasmo administrativo que se produciu pouco despois, coa dilución dos servizos de loita contra o fogo entre diferentes corpos administrativos (bombeiros voluntarios, Protección Civil etc.), restaron eficacia ás diferentes medidas que se foron adoptando. $\mathrm{Na}$ actualidade, despois do revulsivo social e político que supuxo a traxedia dos incendios de xuño e outubro de 2017, creouse unha comisión independente de análise e reflexión sobre o sucedido e, principalmente, con relación ás medidas que desenvolver no futuro, que deu orixe a un importante relatorio (outubro de 2017) que pode ser, se se atenden as súas recomendacións, un punto de inflexión na loita contra os incendios. 


\section{ESTAN QUEIMANDO GALICIA}

A lel de montes do 1.968 recofiece que os montes son dos vecifios, e xa se estan a devolver en toda GALICIA. Pero os que sempre asoballaron ao pobe prendentles lume pra que non quede niņunha riqueza pra os vecinos.

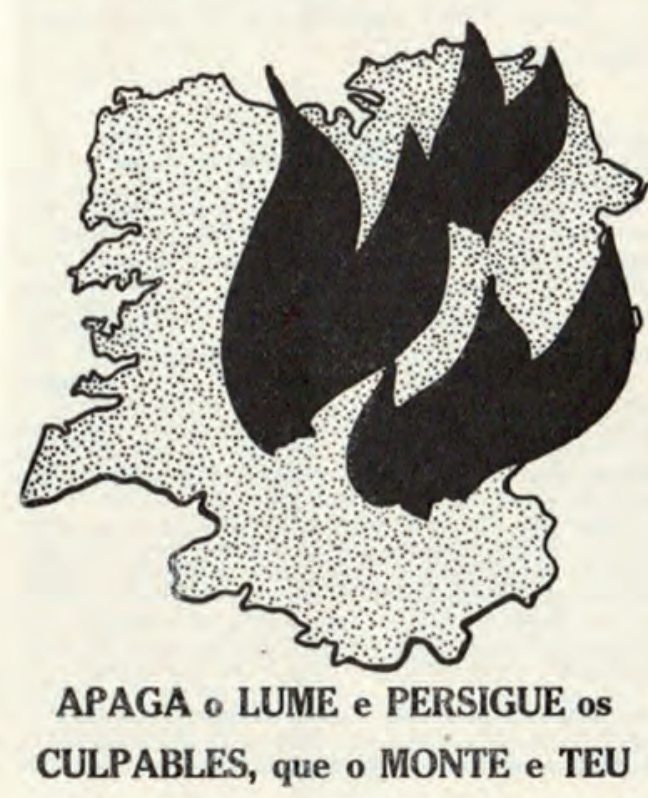

Cordinadora de Montes Conunales.

Figura 14. Cartel de propaganda da campaña contra os incendios forestais da Coordinadora de Montes Comunais de Galicia (1977)
Finalmente, outra característica importante deste período constituíuna a repercusión social que foi adquirindo na opinión pública galaico-portuguesa o tema dos incendios forestais, que pasou de ser unha cuestión secundaria da que só se trataba de maneira circunstancial a figurar como asunto prioritario da axenda política e a ser noticia destacada dos medios de comunicación. En Galicia, posiblemente a primeira acción de toma de conciencia colectiva foi a promovida pola Coordinadora de Montes Comunais en 1977, con accións como o manifesto do Ateneo de Ourense polo Comité de Defensa dos Montes Galegos e as con-

ferencias de Pontevedra de 1978. Despois virían innumerables actuacións dos máis diversos colectivos cidadáns e de sociedades e organismos científicos. En 1987 o Parlamento galego, despois da importante vaga de incendios da década precedente, con tres anos en que houbo máis de 100000 ha ardidas, emitiu un ditame que contiña unha serie de recomendacións elaboradas por unha comisión técnica independente logo de varios meses de comparecencias dos colectivos máis implicados no tema. Tras os incendios do ano 2006, o Parlamento galego volveu 
pronunciarse oficialmente sobre esta cuestión. Pola súa banda, o Consello da Cultura Galega organizou dúas xornadas científicas: no 2006, Os incendios forestais en Galicia e, no 2007, Por unha nova cultura forestal fronte aos incendios.

As institucións científicas e técnicas de Galicia e Portugal desenvolveron desde os anos oitenta amplos e variados programas de investigación, postos en común en numerosas reunións científico-técnicas que deron orixe a continuadas e frutíferas colaboracións. $\mathrm{Na}$ actualidade pódese dicir que a comunidade da ciencia e da técnica dos dous países ten un pensamento compartido sobre a problemática dos incendios forestais que, por outra parte, constitúe unha recoñecida referencia no contexto europeo.

De todas as maneiras, moitos dos temas formulados nas discusións e reunións dos anos oitenta seguen aínda abertos, sobre todo na opinión pública, como son os relativos ás especies pirófilas (maiormente o caso do eucalipto) e o seu papel no risco de incendios, medidas preventivas de política forestal, control do mato, a caracterización, persecución e castigo dos incendiarios, medidas de extinción etc.

\section{UNHA NOVA XERACIÓN DE LUMES?}

Unha investigación realizada mediante satélite (Bowman et al. 2017) de 23000 incendios forestais detectados entre 2002 e 2013 por todo o mundo amosou que 478 podían ser clasificados como megaincendios pola súa extensión e elevada intensidade. Por outra parte, xurdiron estudos americanos (Heyck-Williams et al. 2017) e australianos que, á vez que constataban a presenza destes grandes incendios nos últimos tempos, detectaban tamén unha tendencia ao seu incremento polo menos desde os comezos do século XXI. En Portugal (Ferreira-Leite et al. 2013), nunha análise dos grandes incendios do período 2003-2012, contabilizáronse 14 que se definen como megaincendios por superaren as 10000 ha, frecuencia aquela que era moi superior á detectada nas décadas dos oitenta e noventa do pasado século. En Galicia, os definidos como grandes incendios (maiores de 500 ha) experimentan, así mesmo, unha progresión crecente, de tal 
xeito que representan o 10,6 \% no período 1991-2000, o 27,8 \% no 2001-2010 e o 38,2 \% no 2011-2017. Neste último ano produciuse tamén o primeiro megaincendio (>10000 ha) da comunidade.

As causas ás que se atribúe esta presenza crecente dos megaincendios céntranse primeiramente no cambio climático, que, segundo todas as análises, leva a un incremento do risco de incendios - de resultas, sobre todo, do aumento da temperatura- e, para determinadas zonas, como son as de clima mediterráneo, a unha previsible tendencia cara a unhas maiores secas. De acordo coas ditas análises, estes cambios supoñen unhas condicións máis favorables para as combustións intensas, xunto cunha ampliación do período anual de risco de incendios, ao que se suma a presenza de combustibles cada vez máis secos e inflamables.

Por outra parte, tamén se ponderou a influencia dun maior amoreamento de biomasa combustible, inicialmente provocado por causas socioeconómicas como as consideradas para o espazo galego-portugués, pero tampouco se descartan outras relacionadas coa dinámica da vexetación despois das queimas, que poderían dar orixe ao carácter cíclico que algúns autores (Bermudez et al. 2009) lles atribúen a tales megafogos.

E, como outra característica destes grandes incendios, sinálase a dos danos, cada vez máis importantes e frecuentes, a propiedades e persoas por mor da ampliación, nos últimos tempos, da interface urbano-forestal (IUF). Esta singularidade, consecuencia dun urbanismo mal planificado, leva a que nos operativos de extinción os obxectivos deriven cada vez máis cara á protección, en primeiro lugar, de edificacións e persoas, deixando como tarefas secundarias os clásicos labores de contención do lume forestal.

As cuestións expostas lévannos á pregunta fundamental que xa formulan moitos expertos: estamos diante dunha nova xeración de lumes? Bowman et al. (2011), no estudo que nos serviu de marco conceptual para este traballo, consideran que estamos entrando xa na fase pírica E, cuxas características definitorias son o cambio climático e as modificacións sobre o combustible, e os españois Castellnou e Miralles (2009), no seu esquema de caracterización dos grandes incendios, sitúannos na quinta xeración de incendios, que comezan co século XXI e se distinguen pola súa incidencia sobre a IUF e a aparición dos megaincendios, sen se descartar a posibilidade dunha sexta xeración, que podería xa estar a empezar, como consecuencia, principalmente, do cambio climático, e 
que se manifestaría por unha ampliación do período de risco de incendios e unha maior frecuencia de aparición de fogos incontrolables.

En calquera caso, son unhas expectativas que, analizadas desde a perspectiva histórica que acabamos de utilizar e, sobre todo, coas proxeccións de futuro coas que necesariamente temos que traballar, deberían merecer a nosa maior atención e preocupación. 


\section{REFERENCIAS BIBLIOGRÁFICAS}

ARESES VidAL, Rafael (1929): Los incendios en los montes públicos, Pontevedra, impr. de E. Paredes Valdés. Bauer Manderscheid, Erich (1980): Los montes de España en la Historia, Madrid, Ministerio de Agricultura.

BEIRAS, José Manuel (1967): El problema del desarrollo en la Galicia rural, Vigo, Galaxia.

Bermudez, P. de Zea / J. Mendes / J. M. C. Pereira / K. F. Turkman / M. J. P. Vasconcelos (2009): «Spatial ann temporal extremes of wildfires in Portugal (1984-2004)», International Journal of Wildland Fire, 18, 983-991.

Boserup, Ester (1967): Las condiciones del desarrollo en la agricultura, Madrid, Tecnos.

BOUHIER, Abel (1979): La Galice : essai géographique d'analyse et d'interprétation d'un vieux complexe agraire, tese de doutoramento, Poitiers, Université de Poitiers.

Bowman, David M. J. S. / Jennifer Balch / Paulo ArtaXo / William J. Bond / Mark A. Cochrane / Carla M. D’Antonio / Ruth DeFries / Fay H. Johnston / Jon E. Keeley / Meg A. Krawchuk / Christian A. Kull / Michelle Mack / Max A. Moritz / Stephen Pyne / Christopher I. Roos / Andrew C. SCOTT / Navjot S. SodHI / Thomas W. SWETNAM (2011): «The human dimension of fire regimes on Earth", Journal of Biogeography, 38, 2223-2236.

Carrión Marco, Yolanda (2005): La vegetación mediterránea y atlántica de la Península Ibérica. Nuevas secuencias antracológicas, Valencia, Diputación de Valencia. (Serie de Trabajos Varios; 104).

Casals Costa, Vicente (1988): «Defensa y ordenación del bosque en España. Ciencia, Naturaleza y Sociedad en la obra de los Ingenieros de Montes durante el siglo XIX», Geocrítica, 73, 3-63.

CaSARIego Fernández, Jesús Evaristo (1950): El Marqués de Sargadelos: los comienzos del industrialismo capitalista en España, Oviedo, Real Instituto de Estudios Asturianos.

Castellnou, Marc / Edgar NeBot / Marta Miralles (2007): «El papel del fuego en la gestión del paisaje», IV International Wildfire Conference, Seville, Spain.

Castellnou i Ribau, Marc / Marta Miralles Bover (2009): «The changing face of wildfires», Crisis Response Journal, 5:4, 56-57.

Connor, Simon E. / João Araujo / Willen O. van der KnaAp / Jacqueline F. N. van Leeuwen (2012): "A long-term perspective on biomass burning in the Serra da Estrela, Portugal», Quaternary Science Reviews, 55, 114-124.

DEVY-VARETA, Nicole (1999): «Investigación sobre la Historia Forestal portuguesa en los siglos XIX y XX: orientaciones y lagunas", Historia Agraria, 18, 57-94.

Díaz-Fierros Viqueira, Francisco (2006): A cuestión ambiental en Galicia: raíces dunha nova cultura (1750-1972), Vigo, Galaxia.

Fábregas Valcarce, Ramón / Carlos Fernández Rodríguez / Pablo Ramil Rego (1997): «La adopción de la economía productora en el Noroeste ibérico», en Antón A. Rodríguez Casal (ed.), O Neolítico atlántico e as orixes do megalitismo, Santiago de Compostela, Universidade / Consello da Cultura Galega, 463-484.

Ferreira-Leite, Flora / Luciano Lourenço / António Bento-GonÇALVES (2013): «Large forest fires in mainland Portugal, brief characterization», Méditerranée: Revue géographique des pays méditerranéens, $121,53-65$.

Ferreira Rodrigues, Teresa (coord.) (2008): História da População Portuguesa: das longas permanências à conquista da modernidade, Porto, Afrontamento. 
Fontana TarRats, José María (1977): Historia del clima del Finis-Terrae Gallego, Madrid, ed. fotocopiada. Guitián RIVERA, Luis (1999): «Los incendios forestales a través de la historia: pervivencias y cambios en el uso del fuego en el noroeste peninsular», en Eduardo Araque Jiménez (coord.), Incendios históricos: una aproximación multidisciplinar, Baeza, Universidad Internacional de Andalucía.

GuyetTe, Richard P. / Michael C. Stambaugh / Daniel C. Dey / Rose-Marie MuZIKA (2012): «Predicting fire frequency with chemistry and climate», Ecosystems, 15, 322-335.

Heyck-Williams, Shannon / Lauren Anderson / Bruce A. Stein (2017): Megafires: The Growing Risk to America's Forests, Communities, and Wildlife, Washington, D.C., National Wildlife Federation.

IBÁÑEZ, Antonio Raymundo, marqués de Sargadelos (2009): Discursos económico-políticos sobre la restauración de los montes y plantios en España (1802), ed. de Joaquín Ocampo Suárez-Valdés, Oviedo, Real Instituto de Estudios Asturianos / Xunta de Galicia.

IVERSEN, Johannes (1956): «Forest Clearance in the Stone Age», Scientific American, 194:3, 36-41.

Koutsias, Nikos / Britta AllgöWer / Kostas Kalabokidis / Giorgos Manillis / Panagiotis Balatsos / Johann G. Goldammer (2015): «Fire occurrence zoning from local to global scale in the European Mediterranean basin: implications for multi-scale fire management and policy», iForest. Biogeosciences and Forestry, 9, 195-204.

Lobo Alves, António (coord.) (2003): O Abandono da Actividade Agrícola, Lisboa, Ministério da Agricultura, do Desenvolvimento Rural e das Pescas / Ministério do Ambiente e do Ordenamento do Território.

Martínez-Cortizas, Antonio / Manuela Costa-Casais (2016): «A paisaxe: síntese da historia ambiental e cultural», en Felipe Criado Boado / César Parcero Oubiña / Carlos Otero Vilariño / Elena Cabrejas (eds.), Atlas arqueolóxico da paisaxe galega, Vigo, Xerais.

Molina RodríGuez, Fernando (1979): «Producción e ecoloxía no monte galego», Revista Galega de Estudios Agrarios, 2, 33-56.

Monteiro Alves, António A. / Nicole Devy-Vareta / Ângelo C. Oliveira / João S. Pereira (2006): «A floresta e o fogo através dos tempos», en João Santos Pereira / José Miguel Cardoso Pereira / Francisco Castro Rego / João M. Neves Silva / Tiago Pereira da Silva (coords.), Incêndios Florestais em Portugal: Caracterizacão, Impactes e Prevencão, Lisboa, Instituto Superior de Agronomia, 15-40.

Pausas, Juli G. / Jon E. Keeley (2009): "A Burning Story: The Role of Fire in the History of Life», BioScience, 59, 593-601.

PeChony, Olga / Drew T. SHindell (2010): «Driving forces of global wildfires over the past millennium and the forthcoming century», PNAS, 107:45, 19167-19170.

PYNE, Stephen J. (1997): Vestal Fire: An Environmental History, Told through Fire, of Europe and Europe's Encounter with the World, Seattle / London, University of Washington Press.

Ramil-Rego, Pablo / María Jesús Aira Rodríguez / María Teresa Taboada Castro (1994): «Análisis polínico y sedimentológico de dos turberas en las Sierras Septentrionales de Galicia (N.O. de España)», Revue de Paléobiologie, 13:1, 9-28.

Ruiz Zorrilla, Pedro (1980): «Notas para una historia del pino en Galicia», en Olga Gallego Domínguez / Pedro López Gómez / Pablo Taboada Moure / Antonio Rigueiro Rodríguez (coords.), El monte en Galicia: fuentes para su estudio, Madrid, Ministerio de Cultura.

VélEZ MuÑoz, Ricardo (2015): «Breve (e incompleta) historia de las aportaciones técnicas de los Ingenieros de Montes contra incendios forestales en los pasados 60 años», presentación en PowerPoint (14 de marzo).

Villares PaZ, Ramón (coord.) (1980): Historia de Galiza, Madrid, Alhambra / Caixa de Aforros de Galicia. 


\section{OS INCENDIOS FORESTAIS DO CAMBIO GLOBAL XA ESTÁN AQUÍ. UN DESAFÍO E UNHA OCASION PARA LOGRAR UNHA RESPOSTA SOCIAL CONSENSUADA}

José A. Vega 1

Stéfano Arellano-Pérez ${ }^{2}$

Cristina Fernández ${ }^{1}$

Teresa Fontúrbel ${ }^{1}$

Ana Daría Ruiz ${ }^{2}$

DOI: $10.17075 /$ unxl.2021.002

1 Centro de Investigación Forestal de Lourizán, Consellería do Medio Rural, Xunta de Galicia

2 Unidade de Xestión Ambiental e Forestal Sostible (UXAFORES), Departamento de Enxeñaría Agroforestal, Escola Politécnica Superior de Enxeñaría, Universidade de Santiago de Compostela

Este estudo foi financiado polo Instituto Nacional de Investigación e Tecnoloxía Agraria e Alimentaria (INIA), mediante os proxectos RTA201400011-C06-02 e RTA2017-00042-C05-02, cofinanciados por FEDER (Comisión Europea). Tamén se recoñece o financiamento do Plan de Mellora e Innovación Forestal (2010-2020) da Xunta de Galicia e o de INDITEX. Os autores agradecen o traballo de Elena Pérez coa elaboración de bases de datos. 

O lume no ámbito dos países mediterráneos é un feito cultural e ecolóxico inevitable, pero unha catástrofe evitable (FAO 2008). Ainda en condicións meteorolóxicas extremas, os desastres de incendios forestais non son inevitables

(Calkin, Cohen, Finney e Thompson 2014;

Cohen 2008; Tedim e Leone 2017).

Os humanos alteraron o papel que o lume desempeñou historicamente, ao proporcionar equilibrio ecolóxico. Necesitamos repensar a nosa visión do lume e aceptar a súa presenza, cambiando a forma de xestionar as terras e de planificar as nosas comunidades

(Pyne 2020).

O lume e o uso da terra son parte dun sistema conxunto

(Butsic et al. 2015).

É especialmente critico aprender a xestionar os incendios forestais dun xeito que reduza os riscos aos núcleos de poboación e ao mesmo tempo permita a sustentabilidade dos recursos importante para a estabilidade da biota nativa

(Pausas e Keeley 2009).

\section{INTRODUCIÓN}

$\mathrm{O}$ incendio forestal en Galicia pode considerarse un exemplo dun proceso capaz de xerar o que na literatura de xestión de riscos se vén cualificando como «risco sistémico» (Klinke e Renn 2002, Renn 2008), caracterizado por mostrar unha 
alta complexidade, incerteza e ambigüidade, así como polo seu potencial para producir importantes efectos sociais, económicos e ambientais. A isto habería que engadir outros trazos distintivos, tales que a súa persistencia no tempo e a aptitude para desencadear pola súa vez outros riscos, o chamado «efecto fervenza». As consecuencias hidrolóxico-erosivas dos incendios en Galicia, que frecuentemente se converten en ameazas de posibles novos danos a persoas, bens e recursos (Vega et al. 2013a), ilustran ben esa capacidade do incendio de provocar riscos engadidos.

Con todo, o lume é moito máis que unha fonte de risco; é un fenómeno físico e ecolóxico e tamén social e cultural (Pyne 2000 e 2007, Myers 2006, Bowman et al. 2011, Belcher 2013, Scott 2018, Scott et al. 2014, Roos et al. 2016, McLaughlan 2020). En Galicia, o lume, con todas as súas variantes (queima, estivada etc.), foi usado inveteradamente no ámbito rural, vencellado á agricultura e ao pastoreo (Kaal et al. 2008, Bouhier 1979, Díaz-Fierros 2018), o mesmo que nos países do sur de Europa e outras moitas partes do mundo (Vélez 1986, 1991 e 2005, Seijo e Gray 2012). O lume cumpre ademais un papel ecolóxico moi importante (Pausas et al. 2019a) que a nosa sociedade urbana, en xeral, non acaba de comprender ben, igual que tampouco acepta facilmente as consecuencias que dese feito se derivan (Tedim et al. 2015 e 2020). Como Bowman et al. (2011) sinalan, esa ambigua relación de moitas culturas co lume, a escala da paisaxe, tradúcese en tensións políticas entre grupos que contan con modelos de xestión do lume que compiten entre si. Sen dúbida, en Galicia sábese diso. Tamén pode ser que os traballos científicos axudasen a esa visión só negativa do lume, ao estaren máis centrados en salientar os seus efectos negativos que en ofreceren unha perspectiva máis holística e equilibrada. Todo iso contribuíu a favorecer a estendida percepción catastrofista do lume, fomentada, así mesmo, pola maioría dos medios. De feito, o recoñecemento do carácter dual do lume, capaz de xerar tanto beneficios como danos (Milne et al. 2014, Pausas e Keeley 2019a e 2019b, Ingalsbee 2017, He et al. 2019, DePietri e Orenstein 2019, Sil et al. 2019a), é un punto clave da mudanza de mentalidade necesaria (Tedim et al. 2019) para adaptarse ao cambio dos réximenes do lume por mor do cambio global. Ese cambio está a producir dramáticas consecuencias nunha sociedade non suficientemente preparada (Nature geoscience 2019, Bowman et al. 2017 e 2020). 
Do mesmo xeito que outros territorios europeos, Galicia está inmersa nun proceso de cambio global. Aos desafíos producidos por un acelerado curso de mudanzas socioeconómicas, particularmente no eido rural (Calvo-Iglesias et al. 2009, Vélez 2009, López Iglesias 2018, Corbelle e Crecente, 2014, Regos et al. 2014), hai que engadir os efectos do cambio climático. Os dous tipos de cambio ocorren ao mesmo tempo e afectan ao problema dos incendios forestais. A sociedade galega ten aínda presente o impacto producido por dramáticos episodios de incendios recentes, como a vaga do lumes de outubro de 2017, que deixaron unha notable percepción colectiva de vulnerabilidade fronte a eses eventos e unha profunda preocupación pola posibilidade de que se repitan. Os catastróficos incendios de Portugal, en xuño e outubro de 2017, aumentan tal apreciación. En calquera caso, esa visión do lume non parece promover na sociedade o recoñecemento de que ela mesma contribuíu ao risco. Aínda que este non é o lugar para tratar in extenso as causas do problema dos incendios en Galicia, temos que recoñecer que ten raíces profundamente sociolóxicas. Isto é común con outros moitos territorios onde os lumes son causados en máis dun $95 \%$ polos humanos. En realidade, a sociedade desenvolveu pautas de comportamento traducidas en continuos incrementos da cantidade e continuidade do combustible acumulado e, ao mesmo tempo, non resolveu problemas clave relativos á ordenación do espazo rural, conflitos de uso da terra entre os actores rurais e tensións derivadas de visións contrapostas do monte na poboación urbana e rural, entre outras. Tamén coadxuvaron políticas de reforestación extensa durante anos, sen os necesarios labores silvícolas, plantacións desordenadas de especies forestais sen coidados culturais, por parte de moitos propietarios, abandono de áreas agrícolas e forestais, invadidas logo de matogueira e arboredo ventureiro (Azevedo et al. 2011, Moreira et al. 2011, Fernandes et al. 2016b, Sil et al. 2019b). A chamada transición forestal (Mather, 1992, Mather e Needle 1998, Rudel et al. 2005 e 2010) percorreu en Galicia e moitos países europeos o camiño inverso á agrarización dos séculos pasados, ofrecendo novas producións, beneficios e servizos ecosistémicos ao tempo que creando tamén tensións sociais, desaxustes, disfuncionalidades e redución dalgúns deses servizos (Guijarro et al. 2018, Varela et al. 2020). A iso hai que engadir as prohibicións e restricións de uso do lume durante anos (Guitián Rivera 1999) e a primacía da extinción como as dúas principais ferramentas da xestión dos lumes (Fernandes 2008). Con todo, estas 
dúas últimas respostas resultan parcialmente comprensibles, nun contexto caracterizado polo excesivo número e recorrencia de lumes, ás veces usados como ferramenta de confrontación política e social (Rico Boquete 1994, 2000 e 2018, Balboa-López 1999, Seijo 2005, 2009 e 2012) e prolongadas no tempo, sen que unha parte da sociedade (maioritariamente urbana) demostrase verdadeiro interese por resolver o problema. Así mesmo, a construción de edificacións xunto a espazos forestais, o desenvolvemento dun urbanismo difuso e unha falta de ordenación dos usos do territorio contribuíron notablemente, entre outros factores, a ese resultado. Hoxe sinálase que a extinción dos incendios custe o que custe tamén puido contribuír a agravar o problema. Ese esforzo de extinción de todos os lumes -debido, en gran parte, á súa demonización e á consecuente presión mediática social e política (Delgado Arango 2018, Pérez-Pereiro et al. 2018, Conde Vázquez 2019) sobre os xestores técnicos do lume- é un mal endémico en case todos os países e comporta a inevitable absorción de recursos que poderían destinarse á prevención e outras actividades forestais (Fernandes 2008, Thompson et al. 2015 e 2018). Con esa actuación estase tamén indirectamente contribuíndo á acumulación de combustible e podemos facer os incendios cada vez máis extensos e perigosos, e xerar o ben coñecido paradoxo da extinción (Collins et al. 2013, Calkin et al. 2014 e 2015, North et al. 2015, Moreira et al. 2019) ou caer na «trampa da extinción» (Collins et al. 2013, Castellnou et al. 2020, Xanthopoulos et al. 2020). Con todo, en territorios como Galicia, cun persistente elevado número de ignicións e un alto risco para numerosos núcleos de poboación, o control do lume resulta especialmente necesario e, por tanto, ese equilibrio supón un difícil reto.

É ben sabido que Galicia xunto co norte-centro de Portugal constitúen os territorios da UE que presentan maior ocorrencia e extensión de incendios forestais (Birot 2009, San-Miguel-Ayanz et al. 2013 e 2018), que xeran nesas rexións problemas de gran dimensión social, económica e ambiental. Son territorios propensos ao lume (fire-prone landscapes). Ao mesmo tempo, as proxeccións do cambio climático para os países mediterráneos (incluída Galicia) en xeral auguran un aumento desa ocorrencia e extensión (Moriondo et al. 2006, Moreno et al. 2010, Amatulli et al. 2013, Bedía et al. 2014, Turco et al. 2017 e 2018, Sousa et al. 2015). 
A situación actual parece, por tanto, unha boa oportunidade para reflexionar sobre o problema ao que nos enfrontamos e ponderar ata que punto o clima esperado nos próximos anos pode contribuír a facela máis comprometida.

Hai, con todo, un risco que pode amortecer a resposta da sociedade. A frecuencia de incendios en Galicia e o recordo do seu uso tradicional -nun marco social, económico e de uso do territorio que xa non existe- poden transmitirnos a enganosa idea de que todo segue igual. Pode facernos perder sensibilidade para detectarmos o novo escenario no que a sociedade galega se vai mover e favorecer que, finalmente, non reaccione. Por iso convén ter o presente o reto ao que temos que facer fronte. $\mathrm{O}$ cambio global é tamén unha oportunidade para o cambio da resposta social no eido do lume forestal.

Nas liñas que seguen preséntanse resultados de estudos que poden orientarnos respecto á forma en que se espera que o cambio climático afecte o risco de incendio, como consecuencia da modificación do comportamento do lume esperado e, por tanto, da dificultade de extinción dos incendios e a magnitude dos seus efectos. Inclúense tamén algunhas reflexións e propostas relativas ás accións que a sociedade e a Administración poderían acometer para responder a ese reto que esixirá adaptarnos a un novo escenario. Co obxecto de centrar mellor a cuestión, preséntanse deseguido algúns dos principais trazos do réxime de lume en Galicia.

\section{ALGUNHAS DAS PRINCIPAIS CARACTERÍSTICAS DO RÉXIME DE LUME FORESTAL EN GALICIA}

O termo «réxime», usado inicialmente nun contexto de ecoloxía do lume nos anos oitenta para describir as pautas temporais e espaciais dos impactos do lume nun longo período de tempo (Morgan et al. 1999), foi ampliando pouco a pouco o seu contido ata incluír aspectos físicos e sociolóxicos (Krebs et al. 2010).

Moreno e Chuvieco (2013) propuxeron unha clasificación dos réximes de lume en España e consideraron Galicia como exemplo do tipo caracterizado por unha alta densidade de lumes (número de incendios $\cdot \mathrm{km}^{-2} \cdot \mathrm{ano}^{-1}$ ) e longa estacionalidade (número de meses que presentan densidade significativa). Posteriormente, eses autores (Moreno e Chuvieco 2016) ampliaron os factores conside- 
rados para incluíren aspectos relacionados co clima, a poboación, a produtividade forestal, o tipo de cuberta vexetal e os seus cambios e o gando. Segundo o anterior, Galicia, a moi grandes trazos, sería un exemplo de réxime caracterizado por unha alta densidade de ignicións e longa estacionalidade, cun tamaño de incendio que tende a ser reducido, xunto a unha elevada humidade e produtividade forestal, alta densidade de poboación, dilatado censo gandeiro e rápidos cambios na cuberta de vexetación. Outro trazo do réxime de lume en Galicia, como é o elevado número de incendios en inverno (compartido con outras rexións do norte peninsular), foi tamén frecuentemente destacado (Vega et al. 2009a, Jiménez-Ruano et al. 2017, Barreal e Jannes 2020).

Certamente, en Galicia a maior parte dos parámetros utilizados para reflectir a actividade de incendios (MAPAMA e Pladiga, Xunta de Galicia 2019) presentan valores máis desfavorables que no resto de España e a maioría dos países do sur de Europa, coa excepción de Portugal. De feito, a superficie forestal de Galicia representa o 7,4\% da correspondente área en España, mentres que a súa contribución relativa á superficie queimada nacional no último período contabilizado (2006-2015, MAPAMA) foi do $28 \%$ e $29 \%$ en termos de número de incendios.

Se hai un trazo que caracteriza a situación dos incendios en Galicia, ese é o seu alto número. A súa densidade no período 1978-2017 foi de 3,1 lumes por cada 1000 hectáreas forestais, máis de doce veces superior á do resto de España. Neses corenta anos, o 39 \% dos incendios forestais de España ocorreron en Galicia. Ningunha tendencia de ascenso ou descenso estatisticamente significativa se aprecia nese longo período no seu conxunto. Non obstante, de 1978 a 1995 (o ano co maior número de incendios referido) a densidade media foi de 7,7 lumes/1000 ha, mentres que entre 1995 e 2017 baixou a 3,5, dentro dunha tendencia significativa a diminuír. Desde a entrada en servizo dunha unidade específica da administración forestal dedicada á prevención e defensa contra incendios en 1990, a ocorrencia de lumes reduciuse de maneira significativa (Figura 1), o que apunta a que as accións promovidas están a producir resultados positivos.

A extensión media queimada cada ano en Galicia nos últimos corenta é dunhas 41000 ha. Esa cifra supón un cociente (ratio) de área forestal queimada do 2,02 \%, unhas catro veces superior á do resto de España en igual período. 


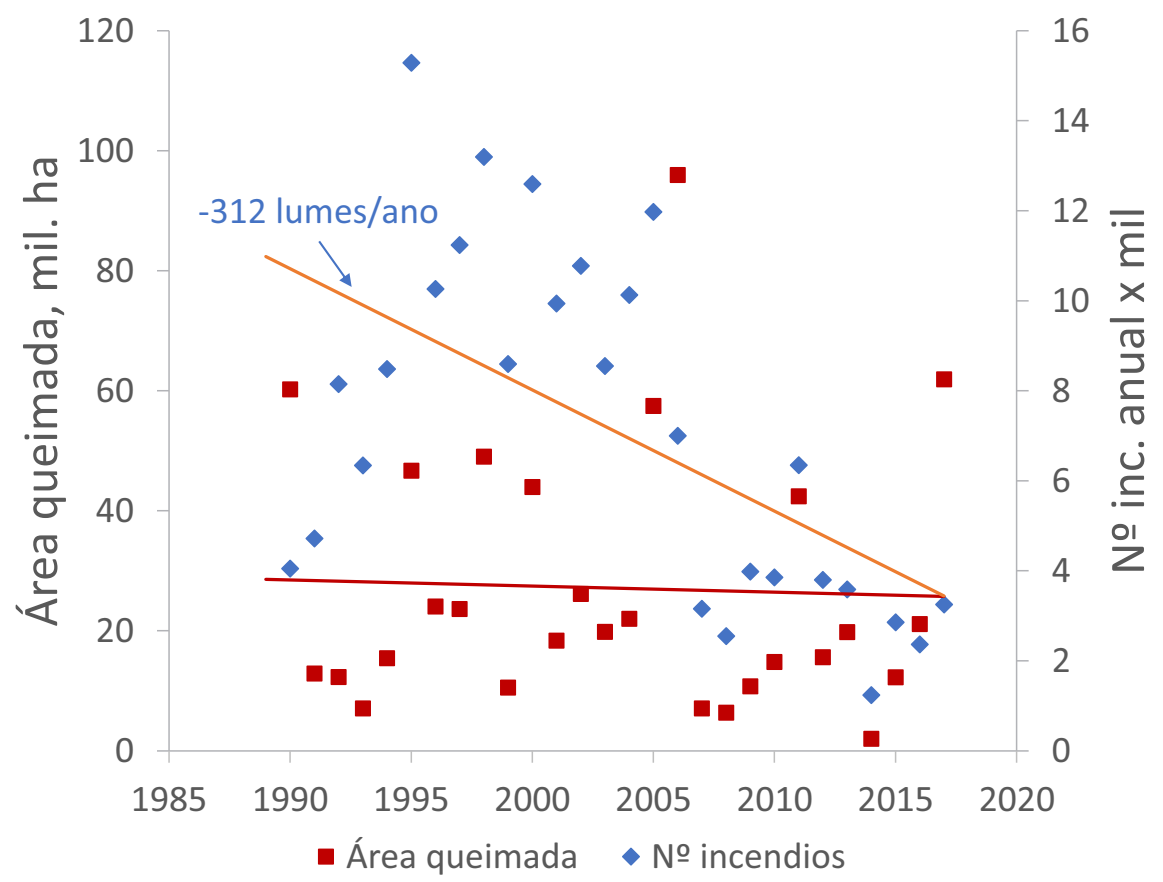

Figura 1. Evolución do número de incendios e da área queimada anuais entre 1990 e 2017. Mentres que a tendencia no número de incendios é decrecente nun grao significativo (pendente indicada na figura), a área anual queimada non mostra ningunha tendencia significativa

A maior parte $(67,8 \%)$ desa superficie corresponde a matogueira e representa un $23 \%$ da queimada en España nese período. A ratio citada mostrou unha tendencia significativa a decrecer co tempo neses corenta anos. Isto traduciuse en pasar do 3,63 \% do citado cociente antes de 1991 (un punto de cambio pronunciado na serie) a case tres veces menos desde esa data ata 2017. Malia todo, o descenso non foi uniforme espacialmente, e en Pontevedra e Ourense, onde a área queimada anualmente continúa sendo moi elevada, desde 1992 ata 2017, non se detectou unha tendencia a diminuír, mentres que nas outras dúas provincias si o fixo. En conxunto, desde 1990, a superficie queimada cada ano en Galicia non diminuíu de maneira significativa (Figura 1), un dato moi preocupante. Como media para Galicia, o período de rotación do lume nos últimos corenta anos é de 49,5 anos. Pontevedra, con tan só 32,4 anos, e Ourense, con 
37,4 anos, son as provincias que sofren unha presión de lume reiterada máis alta, fronte á Coruña (66,4 anos) e Lugo (78,4 anos). Unha redución do período de rotación tradúcese con frecuencia en maiores efectos ecolóxicos do lume porque o sistema ten menos tempo para recuperarse. Dentro desas provincias tampouco esa incidencia é uniforme, e concéntrase principalmente na parte occidental e suroeste para Pontevedra e A Coruña, mentres que en Ourense, na suroeste e sueste, e en Lugo, na suroeste e leste (Figura 2).

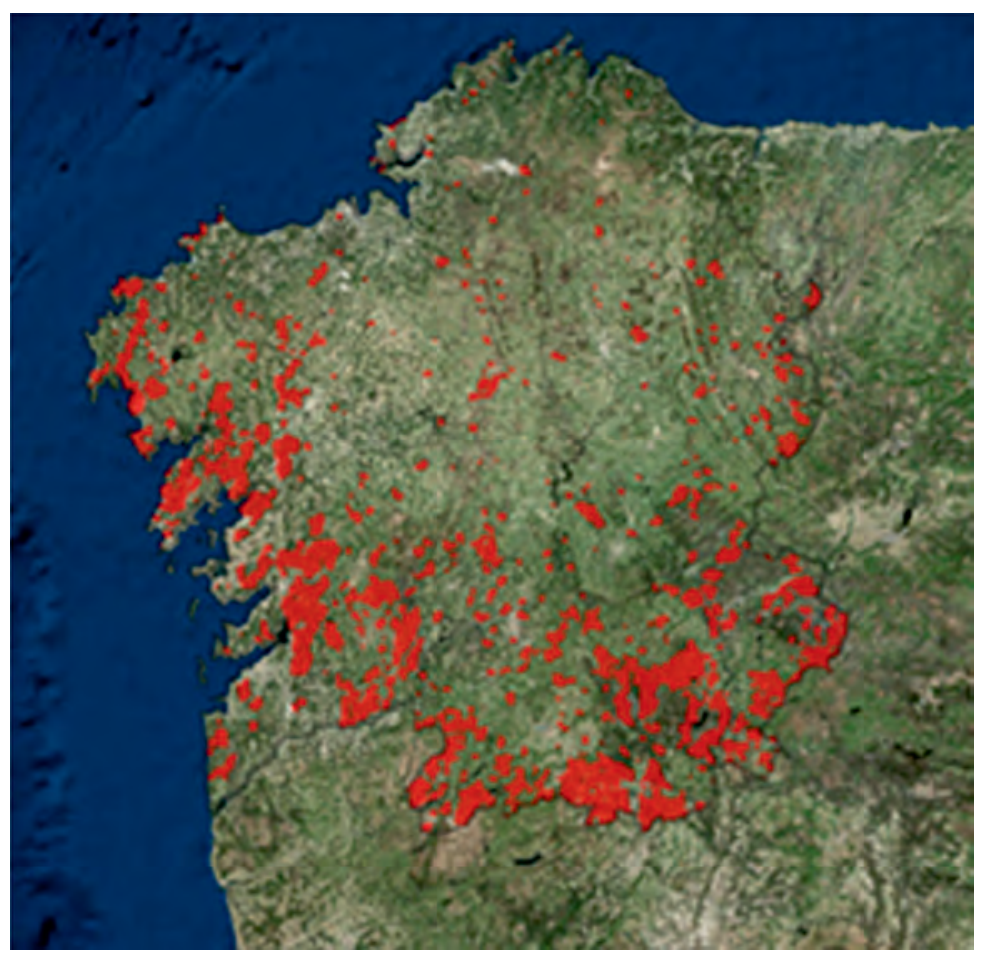

Figura 2. Área queimada entre 2001 e 2017 en Galicia. Composición de imaxe desenvolvida por Adrián Regos, baseada en imaxes de MODIS (NASA LP DACC, 2017).

Dispoñible en https://arcg.is/1Orfj4

Respecto ao tamaño das áreas queimadas, o $79 \%$ dos incendios de Galicia entre 1978 e 2017 tivo menos dunha hectárea, fronte ao $58 \%$ do resto de España, e o tamaño medio de incendio foi de 8,5 ha, notablemente inferior ao do resto do país $(18,2 \mathrm{ha})$, indicando unha boa efectividade do sistema de 
extinción de Galicia, se ben estas cifras mostran moita variabilidade e unha tendencia a aumentar entre 1991 e 2017. O número de grandes incendios ( $>500$ ha) en Galicia foi de 7,6 lumes/ano, que constitúen unha porcentaxe moi pequena do total $(0,16 \%)$ pero queiman ao redor dun $16 \%$ da superficie ardida $(37,2 \%$ no resto de España). Esta é unha característica típica dos grandes incendios na área mediterránea e outras partes do mundo (Camia et al. 2011, San-Miguel-Ayanz et al. 2013); con todo, non moi pronunciada en Galicia.

Malia que se trata de signos comparativamente positivos, hai outros negativos. Entre eles cabe destacar que non existe tendencia ao descenso na porcentaxe que representan os grandes incendios en Galicia, respecto ao número anual total de incendios, mentres que decreceron no resto do país, e a porcentaxe de superficie queimada por eles creceu en Galicia, aínda que se mantivo estable nas outras áreas españolas.

A inhomoxeneidade espacial e temporal do número de incendios e a área queimada en Galicia recibiron atención nun número de estudos (p. ex. Chas-Amil et al. 2010 e 2013, Prestemon et al. 2012, Balsa-Barreiro e Hermosilla 2013, Fuentes Santos et al. 2013, Barreal e Loureiro 2013 e 2015, Boubeta et al. 2015, Costafreda-Aumedes et al. 2016, Ríos-Pena et al. 2017, Barreal e Jannes 2020). A distribución estacional do número de incendios foise convertendo en bimodal, ao longo dos últimos decenios cun alongamento do período de perigo que presenta dous máximos relativos en marzo e agosto; non obstante, para a superficie queimada segue sendo unimodal, cun máximo en agosto (Vega et al. 2009a, Barreal e Jannes 2020). A simultaneidade de ignicións é outro trazo característico da situación dos incendios en Galicia. Téñense con relativa frecuencia días de máis de 100 lumes e observáronse ata 425 lumes/día (Fernández-Couto 2006), e isto ocorre maioritariamente cando as condicións meteorolóxicas son máis adversas (García-Díez et al. 1994 e 1997), o cal provoca un desbordamento do operativo de extinción e frecuentes e perigosos escapes e reproducións (Cela 2018).

A alta densidade de poboación en moitas comarcas, en especial as occidentais, introduce un factor engadido ao risco, xa que os incendios con frecuencia acaban ameazando núcleos de poboación. Isto complica en gran medida a extinción e diminúe o seu rendemento, ao térense que desviar recursos para atender a protección das persoas e vivendas. 
Como sucede noutras rexións do sur de Europa (Vilar del Hoyo et al. 2009, Ganteaume et al. 2013), a inmensa maioría dos incendios en Galicia (98,2 \%) son de orixe humana. Esa cifra está próxima á media europea $(97,1 \%)$. No entanto, unha característica propia de Galicia é a súa elevada taxa de lumes intencionados (ao redor do $78 \%$ do total, segundo MAPAMA s. d.). Dentro desa categoría, os producidos por queimas que teñen finalidade agrícola e pastoral supoñen a maior porcentaxe, un $43,4 \%$, mentres que os de orixe descoñecida representan un $34,2 \%$. Incendiarios, vandalismo, protestas e disputas locais calcúlase que suman ao redor dun 17,5\%. Aínda que a investigación de causas tropeza con grandes dificultades e a asignación a algunhas desas motivacións é discutible, o anterior resalta dous aspectos esenciais do réxime de lume en Galicia. Por unha banda, a longa tradición cultural no uso do lume mantida no tempo, nun contexto moi diferente ao do pasado en canto á estrutura da vexetación na paisaxe e ao coñecemento no manexo do lume pola poboación. Baste reparar no que supón realizar máis de 300000 queimas agrícolas e máis de 6000 forestais en 2017 (Barreiro 2018, comunicación persoal). Por outra, o incendio provocado parece a expresión dun cadro de problemas socieconómicos con tensións e conflitos subxacentes non resoltos, e pautas espaciais e temporais que suxiren influencias dunha ampla variedade de motivacións e que amosan un forte compoñente imitativo (Marey-Pérez e Rodríguez Vicente 2008, Chas-Amil et al. 2010, Gómez-Vázquez et al. 2009, Barreal et al. 2012, Prestemon et al. 2012, Fuentes-Santos et al. 2013, Pazos Lamoso et al. 2018, Da Ponte et al. 2019, De Diego et al. 2019). O resultado é a recorrencia de incendios en áreas determinadas (Barreal e Loureiro, 2013, 2015, Boubeta et al. 2015, Costafreda-Aumedes et al. 2014, 2016), que comporta unha degradación da vexetación e o solo nos ecosistemas afectados (Regos et al. 2014), unha desmotivación das iniciativas económicas ligadas ao sector forestal e o desalento e desentendemento da poboacion neles. Os datos respecto ao cambio dese cadro non son moi alentadores. Por exemplo, as porcentaxes de incendios intencionados e de causa descoñecida nos últimos 25 anos apenas variaron. Sinalan a necesidade de actuar nese eido.

A crecente incidencia dos incendios nunha moi extensa interface urbano-forestal é tamén un trazo típico do réxime de lume forestal en Galicia (Chas-Amil et al. 2013, 2015 e 2020, Calviño-Cancela et al. 2016 e 2017), consecuencia dunha forma de vida e falta dun planeamento territorial que resulta 
nun urbanismo difuso, e, máis recentemente, doutros factores do cambio global, o que introduce un elemento de complexidade na xestión do lume forestal. Isto xera preocupación no tocante ao futuro manexo de situacións de alto risco para a poboación en relación cos incendios forestais.

Finalmente, un dos aspectos máis inquietantes do réxime de lume en Galicia atópase na ocorrencia de episódicos estalidos de lumes catastróficos ou «vagas de lumes», como as de 2006 e 2017 -nalgúns aspectos, diferentes da que produciu os grandes incendios de 1989-. Mentres que estes últimos eran aínda «lumes estritamente forestais», os outros dous episodios representan un novo tipo de incendios, caracterizados polo elevado número de ignicións, concentradas en determinadas áreas, que causaron un impacto sobre a interface urbano-forestal (en sentido amplo) descoñecido ata o de agora e baixo condicións meteorolóxicas en extremo perigosas (Cruz Guerrero et al. 2007, Parlamento de Galicia 2018, este estudo). Claramente, este tipo de incendios é capaz de producir un colapso no sistema de extinción (Cela 2018). Resulta previsible que, baixo a crecente influencia do cambio climático, a ocorrencia desta clase de lumes, que teñen o potencial de desencadear consecuencias catastróficas, poida darse no futuro próximo con maior frecuencia.

\section{COMO FOI A INFLUENCIA DO CLIMA SOBRE A SITUACIÓN DE PERIGO DE INCENDIOS NOS ÚLTIMOS DECENIOS EN GALICIA?}

O clima é determinante no inicio e propagación do lume nos incendios forestais. O tipo e cantidade de vexetación que constitúe o combustible dos incendios é a consecuencia das características climáticas, edáficas e do uso da terra. Por outra banda, o contido da auga na vexetación é un factor clave na súa inflamabilidade (en sentido amplo) e vén controlada, en boa medida, polas condicións climáticas. A vexetación viva ten un contido de auga dependente, basicamente, da especie, da variación estacional debida á fenoloxía e das condicións meteorolóxicas antecedentes a medio prazo (Yebra et al. 2013, Resco de Dios, 2020, Marino et al. 2020). Pola contra, os combustibles finos mortos, integrados polas fraccións de vexetación seca de escaso grosor (<6 $\mathrm{mm}$ de espesor), presentan unha maior dependencia das condicións meteorolóxicas a curto prazo, 
con oscilacións diarias moi acusadas e mesmo diúrnas. É por iso que se considera a humidade do combustible fino morto un parámetro de grande interese en incendios xa que pode ofrecer información de moita utilidade para expresar a facilidade de ignición e propagación do lume e, por tanto, ser usado como un indicador de perigo diario de incendios, ademais doutros usos. A modelización da humidade deses combustibles en función de parámetros meteorolóxicos (Nelson 2001, Mathews 2012) permite elaborar diversos índices de perigo de incendios forestais, usados operacionalmente polos servizos de protección contra incendios (p. ex. McArthur 1962, Bradshaw et al. 1983, Forestry Canada Fire Danger Group 1992).

O coñecemento actual dos efectos do cambio climático sobre os incendios forestais en Galicia, referidos ao pasado recente, é aínda moi escaso. Entre 2007 e 2009 a Consellería de Medio Ambiente desenvolveu un proxecto interdisciplinar (CLIGAL), coa intervención de diversos organismos de investigación e máis dun centenar de investigadores, sobre as evidencias e posibles impactos do cambio climático en Galicia. Un dos temas abordados foi o do perigo de incendio, tomando como base a predición da humidade dos combustibles finos mortos (Vega et al. 2009a e 2009b). O estudo foi ampliado nalgúns aspectos en Arellano (2011) e, posteriormente, coa recompilación de novos datos para o período 2006-2017, gañouse en perspectiva. Usáronse un conxunto de índices de perigo de incendios (australianos, canadenses e estadounidenses) referidos aos seus valores no verán e en marzo. En liñas xerais, estes descritores reflicten a facilidade de ignición e de propagación do lume a través dos combustibles forestais (véxase unha revisión en Ruiz-González e Vega 2007). Tamén, dada a súa dependencia das condicións meteorolóxicas, se converten en potenciais detectores de cambio climático cando se analizan as súas tendencias nun período de tempo suficientemente longo.

Os índices australianos e estadounidenses que se empregaron foron estimadores directos da humidade da frouma ou de herbáceas secas. En concreto, usáronse os seguintes: CBEF (McArthur 1962, Gill 1987, Viney e Hatton 1989), FFDM (McArthur 1967), SMC (Sneeuwjagt e Peet 1985), FBO (Rothermel 1983), Behave (Rothermel et al. 1986) e GFDM (McArthur 1966). Un descenso destes índices supón un empeoramento da situación de perigo. Ademais, usáronse diversos índices canadenses (Van Wagner 1987, Forestry Canada Fire 
Danger Group 1992), construídos de forma que un aumento dos seus valores implica un agravamento das condicións de perigo. Unha parte destes últimos índices expresan de maneira indirecta a humidade da frouma (FFMC) e do humus (DMC) e os efectos da seca acumulada (DC) -Wotton 2008-. Os restantes son estimadores da dispoñibilidade de combustible para o lume (BUI) e parámetros de comportamento do lume tales como a velocidade de propagación do lume (ISI) e a potencia lineal da fronte de chamas (FWI), este último combinando o efecto conxunto dos dous anteriores.

Tres cuestións foron formuladas nestes tres estudos:

a) Mostraron os índices de perigo de incendios forestais máis usados, tendencias de cambio significativas entre 1961 e 2006 en Galicia?

b) Explican eses índices parte da variabilidade do número de incendios e área queimada nese período?

c) Confirman os datos dos índices para o período 2007-2017 as tendencias observadas para o período anterior?

\section{a) Tendencias do perigo meteorolóxico entre 1961 e 2006}

Os resultados principais obtidos expóñense deseguido:

a.1. Detectouse unha tendencia significativa a incrementarse a duración da época de perigo de incendios en Galicia, coa xeración dunha distribución bimodal do número de incendios que amosa máximos en marzo e agosto nas catro provincias, proceso que se foi acentuando co tempo. Isto é concordante cun incremento da duración da época de perigo de incendios en certas rexións do planeta (principalmente Australia, Norteamérica e a conca mediterránea) nos últimos decenios (Jolly et al. 2015) e no futuro (Dupuy et al. 2020).

a.2. A maior parte dos índices (64\%) presentaron tendencias significativas de empeoramento do perigo de incendios no verán ao longo do período estudado. Isto foi interpretado nun sentido dobre: por unha banda, o cambio climático aumentou o perigo meteorolóxico de incendios no período do estudo (entre 33 e 45 anos, segundo os sitios) e, por outra, os índices analizados poden considerarse unha evidencia máis do cambio climático ocorrido en Galicia nese intervalo de anos.

a.3. Os índices que estiman a humidade da frouma e dos combustibles finos secos dunha maneira máis simple reflectiron, en conxunto, o cambio climático 
con máis claridade e, polo tanto, expresaron tamén máis nitidamente a situación de agravamento do perigo que os máis complexos e indirectos.

a.4. Os valores medios para Galicia dos índices canadenses estivais no período 1973-2006 consideráronse, en xeral, moderados para tres provincias, excepto para Ourense, onde DC e FWI foron altos. Se se asume que o índice canadense DSR expresa a dificultade de extinción, a súa media entre 1973 e $2006(4,31)$ foi 1,78 veces superior en Ourense que nas outras provincias, nas que DSR non difería entre elas.

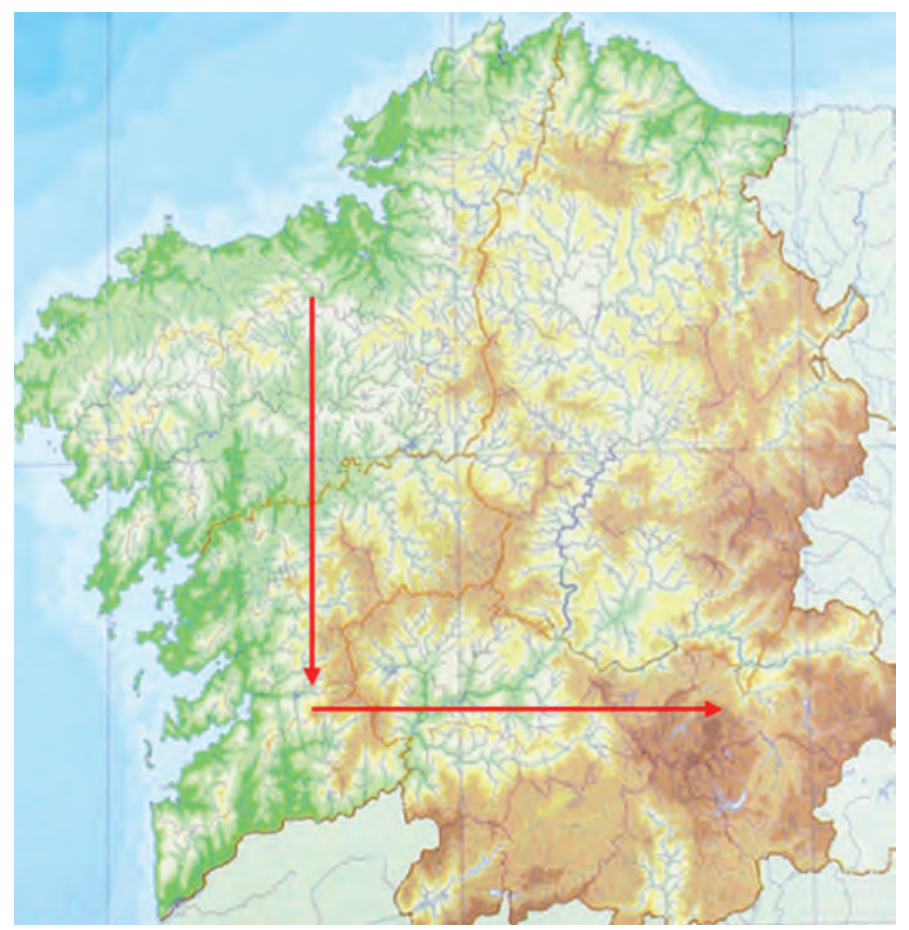

Figura 3. Sentidos dos gradientes de incremento das condicións de perigo de incendio, debido ao cambio climático

a.5. En liñas xerais, detectáronse dous gradientes no empeoramento das condicións de perigo de incendios (Figura 3): un de aumento de norte a sur e outro de crecemento de oeste a leste. Isto implica un incremento do perigo desde o norte da Coruña ao sur de Pontevedra e desde a costa ao interior, e é maior, en xeral, na parte oriental de Lugo que na costa, para a mesma latitude, e máis 
elevado en Ourense. Se isto se enfronta coa distribución espacial dos incendios en Galicia -cunha forte concentración de área queimada no suroeste e no sueste- (Figura 2), apréciase a concordancia de ambos os feitos. Iso subliña o peso da compoñente climática na distribución espacial dos incendios, a pesar da forte influencia doutros factores.

a.6. É conveniente destacar que unhas alteracións aparentemente pequenas nos valores absolutos da humidade do combustible fino morto, producidas polo cambio climático no período de tempo estudado -que, en principio, poderían considerarse pouco relevantes para o cadro xeral de incendios-, se traducen, con todo, nunha amplificación notable do empeoramento do comportamento do lume. Un exemplo ilustra este efecto. A media estimada da humidade do combustible fino morto en Pontevedra para o período 1961-1965 foi dun $14 \%$ e baixou ao $12 \%$ en 2002-2006. Pola súa banda, en Ourense, o $13 \%$ de media durante 1973-1977 diminuíu a un $10 \%$ en 2002-2006. Eses descensos de humidade traducíronse nun significativo agravamento do comportamento medio esperado do lume (Táboa 1), cun crecemento potencial pronunciado da área queimada e do perímetro do incendio, en igualdade dos restantes factores. En termos relativos, os aumentos das variables modeladas foron considerables (entre o $16,5 \%$ e o $92,5 \%$ ), o que implica, por citarmos algúns efectos, unha maior dificultade de extinción e facilidade para que os escapes se convertan en grandes incendios, xunto a consecuencias socioeconómicas e ambientais máis graves.

a.7. Se os anteriores resultados se poñen en conxunto cos cambios socioeconómicos e o aumento dos combustibles forestais acontecidos no ámbito rural neses mesmos períodos (Barreal et al. 2012, López Iglesias 2018, López Iglesias e Pérez Fra 2004, Sineiro 2006, Chas-Amil et al. 2015), o efecto combinado debuxa un cadro moi desacougante.

b) Asociación entre os indices de perigo e a actividade de incendios. Os indicadores canadenses FWI, BUI, DMC e FFMC (meses de xuño a setembro) mostraron conexións máis estreitas coa actividade de incendios que os estimadores máis directos da humidade da frouma entre 1973 e 2006. De feito, absorberon un $54 \%$ da variabilidade do número de incendios de verán, para o conxunto de Galicia, e o $45 \%$ da área queimada coa mesmas variables mais DC e SMC, no período 1973-2006. Estes resultados están en liña cos de Manta e Viegas (2006) 
José A. Vega, Stéfano Arellano-Pérez, Cristina Fernández, Teresa Fontúrbel e Ana Daría Ruiz

Táboa 1. Simulación do efecto do cambio climático en diversas variables de comportamento do lume entre 1961 e 2006 en Pontevedra e Ourense

\begin{tabular}{|c|c|c|c|c|c|c|}
\hline Sitio & $\begin{array}{l}\text { Humidade do } \\
\text { combustible } \\
\text { fino morto, \% }\end{array}$ & \begin{tabular}{|l} 
Velocidade \\
de avance do \\
lume, $\mathrm{m} / \mathrm{h}$
\end{tabular} & $\begin{array}{l}\text { Área queimada } \\
\text { na primeira } \\
\text { hora, ha/h }\end{array}$ & $\begin{array}{l}\text { Perímetro na } \\
\text { primeira hora, } \\
\mathrm{m}\end{array}$ & $\begin{array}{l}\text { Potencia } \\
\text { da front } \\
\text { chamas, }\end{array}$ & $\begin{array}{l}\text { lineal } \\
\text { de } \\
\mathrm{kW} / \mathrm{m}\end{array}$ \\
\hline \multirow[t]{2}{*}{ Períodos } & 1961- 2002- & 1961- 2002- & 1961- 2002- & 1961- 2002- & $1961-$ & $2002-$ \\
\hline & 2006 & 1965 & 19652006 & 1965 & 1965 & 2006 \\
\hline Pontevedra & 12 & $1.017 \quad 1.185$ & 49 & 2.834 & 16.957 & 19.770 \\
\hline \multirow[t]{2}{*}{ Períodos } & 1973- 2002- & 1973- 2002- & 1973- 2002- & 1973- 2002- & 1973- & 2002- \\
\hline & 19772006 & 19772006 & 19772006 & 1977 & 1977 & 2006 \\
\hline Ourense & 10 & 623 & 27 & 1.910 & 10.400 & 13.193 \\
\hline
\end{tabular}

Utilizouse o modelo de Anderson et al. (2015) de matogueiras de clima tépedo. As humidades do combustible fino seco en Pontevedra e Ourense empregadas son, respectivamente, os valores medios estimados polo modelo CBEF (McArthur 1962, Gill et al. 1987 e Viney e Hatton 1989) para os períodos respectivos. Nos dous sitios considerouse un combustible de matogueira de toxo (U. europaeus) de $1 \mathrm{~m}$ de altura, cunha carga de $23 \mathrm{Mg} /$ ha para a fracción menor de $6 \mathrm{~mm}$ de grosor do estrato de combustible elevado e de $17 \mathrm{Mg} / \mathrm{ha}$ para o estrato de frouma (Arellano et al. 2017), cun grao de consunción na fase de chamas do combustible elevado do $85 \%$ (Vega et al. 2000a); asumiuse un $75 \%$ de consunción para a frouma. Vento de $22 \mathrm{~km} / \mathrm{h}$ (a $10 \mathrm{~m}$ ) en Pontevedra (percentil 90, da estación meteorolóxica de Vigo) e de $11 \mathrm{~km} / \mathrm{h}$ en Ourense (percentil 90 da estación de Ourense), cun factor de axuste de vento de 0,50 en ambos os casos, en terreo chairo. A humidade do combustible vivo fino foi modelada en función do DC (Viegas et al. 2004) e resultou ser do $111 \%$ para Pontevedra e do $72 \%$ e o $71 \%$ para Ourense nos dous períodos, respectivamente. A potencia lineal da fronte de chamas determinouse segundo Byram (1959a), supoñendo unha calor de combustión de 18600 kJ/kg. A área queimada e o perímetro calculáronse segundo Rothermel (1983).

para o período 1991-2000. Estes autores observaran unha boa correlación entre o FWI e o número de incendios e a área queimada diarios, no verán e no comezo do outono, en Lugo e na Coruña e máis escasamente en Ourense. Tamén cos de Urbieta et al. (2015) para un período posterior (1985-2011), que atoparon que o FWI deu conta de porcentaxes similares de variabilidade do número de incendios ( $44 \%)$ e da área queimada $(46 \%)$ e, en menor medida, do número de grandes incendios. O mesmo cadro tívose para Portugal (Fernandes et al. 2014 e 2016a) e a Europa mediterránea no seu conxunto (Camia et al. 2008, Camia e Amatulli 2009). As relacións entre os índices de perigo citados e a actividade de lume variaron segundo a provincia, mostrando Ourense as correlacións máis altas. As relacións achadas parecen compatibles coa forte intencionalidade dos incendios en Galicia. Que os índices canadenses -que teñen en conta 
o efecto acumulativo da seca- presenten mellores relacións coa actividade de incendios apunta a que, ademais da maior facilidade de ignición dos combustibles finos, típica das neglixencias, o incendiario opera cunha intencionalidade que busca as dúas eficacias: na ignición e nas consecuencias.

c) Respecto ás tendencias dos indices entre 2007 e 2017 inclusive

c.1. É importante destacar un incremento do perigo (medido pola pendente da tendencia) neste segundo período, con respecto ao primeiro, na metade sur de Galicia, máis pronunciado en Ourense. En Pontevedra aparecen incrementos significativos co tempo nalgúns índices, como o FFMC e o DMC, non detectados no estudo previo (Táboa 2). Isto apunta a un empeoramento dos condicionantes meteorolóxicos do incendio, cos seus concomitantes efectos no comportamento do lume e as súas repercusións ambientais. Confírmanse tamén os dous gradientes espaciais achados antes, que se fan aínda máis pronunciados.

Táboa 2. Pendentes das tendencias dos valores medios anuais dos índices de perigo de incendios GFDM, FFDM, FFMC, DMC e DC no verán para os períodos considerados en Pontevedra e Ourense

\begin{tabular}{|l|l|l|l|l|l|l|}
\hline Provincia & Período & GFDM & FFDM & FFMC & DMC & DC \\
\hline Pontevedra & $1961-2006$ & $-0,051^{* * *}$ & $-0,061^{* * *}$ & ns & ns & ns \\
\cline { 2 - 7 } & $1961-2017$ & $-0,064^{* * *}$ & $-0,080^{* * *}$ & $0,130^{* * *}$ & ns & $0,273^{* *}$ \\
\hline \multirow{2}{*}{ Ourense } & $1973-2006$ & $-0,089^{* * *}$ & $-0,059^{* * *}$ & $0,169^{* * *}$ & $0,806^{* *}$ & ns \\
\cline { 2 - 7 } & $1973-2017$ & $-0,114^{* * *}$ & $-0,087^{* * *}$ & $0,300^{* * *}$ & $1,899^{* * *}$ & $3,591^{* *}$ \\
\hline
\end{tabular}

${ }^{* *} \mathrm{p}<0,01 ;{ }^{* * *} \mathrm{p}<0,001 ; \mathrm{ns}=$ non significativo

Por exemplo, a media da humidade estimada da herba seca, GFDM, pasou de estar en arredor do $11 \%$ nos primeiros anos dos setenta en Ourense a situarse en aproximadamente o $6 \%$ na primeira década do século XXI. Mentres tanto, en Pontevedra, entre esas mesmas datas, a humidade media estimada pasou do $14 \%$ ao $11 \%$ (Figura 4). O anterior implica que no sur de Galicia a diferenza de comportamento do lume nos incendios entre o oeste costeiro e o leste interior aumentou no último decenio. Pola súa banda, o valor medio de DMC pasou en Ourense, nese período, de estar en 50, no ano 1973 (un valor moderado), a acharse en 160, pola altura de 2015 (Figura 5), un valor moi alto, mentres que en Pontevedra o fixo desde 28 ata ao redor de 50, os dous moderados. 
Iso significa que en Ourense está dispoñible moito máis combustible groso para intervir na combustión e, por tanto, que é esperable unha gravidade máis elevada do lume no solo, en igualdade doutros factores.
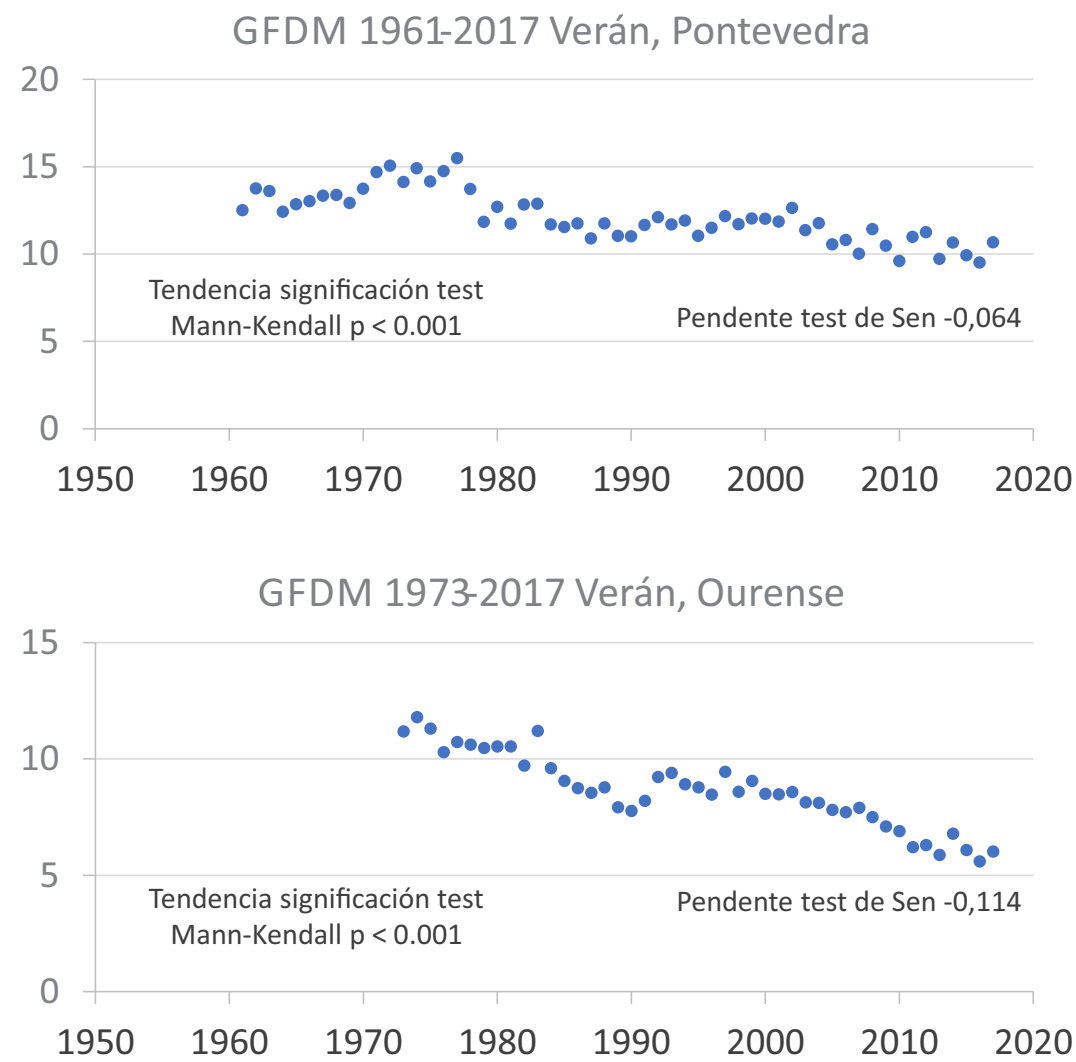

Figura 4. Variación no tempo do descritor australiano GFDM (McArthur 1966) da humidade de herbáceas para Pontevedra e Ourense, correspondente aos meses de verán

c.2. Nas tendencias do percentil 90 dos índices canadenses de perigo estival nese novo intervalo de tempo observouse un incremento do número de provincias onde os citados percentís dos índices aumentaban de maneira significativa co tempo, respecto ao tido para as series ata 2006. Isto interpretouse como unha evidencia do empeoramento da situación tamén para os días en que o perigo é 
máis elevado que para os de perigo medio. Noutros estudos ese percentil estivo relacionado dun xeito significativo coa superficie queimada, p.e. en Portugal (Pereira et al. 2005, Fernandes et al. 2014) e tamén coa ardida nos incendios de gran tamaño nese país (Fernandes et al. 2016a). No seu conxunto, os resultados anteriores poñen de manifesto un escenario de maior perigo de incendio, onde os lumes poden desenvolver comportamentos extremos.

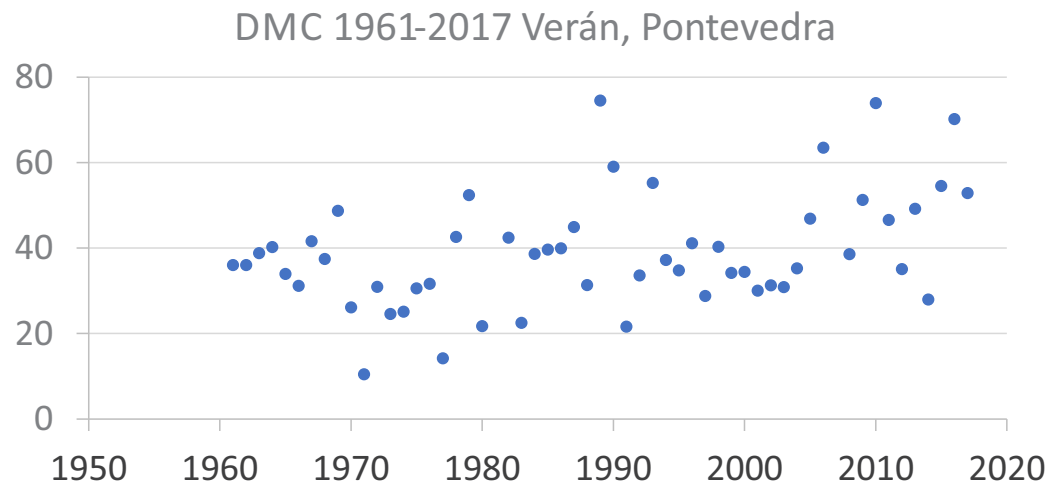

DMC 1973-2017 Verán, Ourense

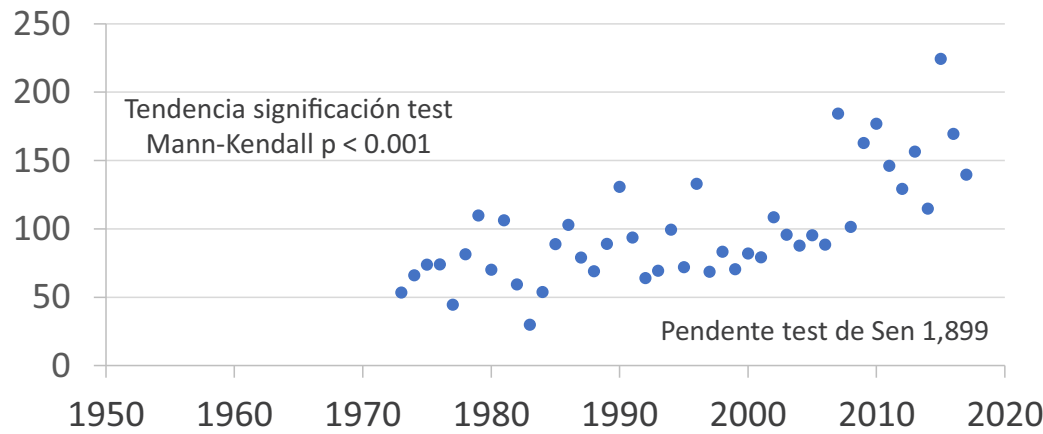

Figura 5. Comparación das tendencias dos valores medios anuais do descritor DMC (Van Wagner 1987) en Ourense e Pontevedra, correspondentes aos meses de verán 


\section{QUE CABÍA ESPERAR, ANTES DE SE PRODUCIREN OS INCENDIOS DE 2017, DA INFLUENCIA DO CAMBIO CLIMÁTICO RESPECTO AO PERIGO EN GALICIA A MEDIO E LONGO PRAZO?}

Fíxose xa habitual nos medios de comunicación presupoñer que a subida da temperatura media anual e das máximas no verán inevitablemente producirán un incremento no número de incendios e na área queimada en Galicia. Pero a magnitude e velocidade deses cambios e como estes afectarán á dificultade de extinción e, por tanto, á poboación e tamén ás consecuencias postincendio implican un alto grao de incerteza. $\mathrm{Na}$ actualidade existe aínda unha forte limitación da capacidade para efectuar proxeccións das condicións meteorolóxicas a medio e longo prazo, xunto á posibilidade de alteración delas pola irrupción de eventos inesperados debido a procesos non ben coñecidos. En gran medida, esas predicións dependen do ritmo das emisións de gases de efecto invernadoiro, difícil de prever. A isto hai que engadir un dinamismo socioeconómico que, como se viu, en poucos anos pode provocar importantes cambios na estrutura espacial dos combustibles a escala da paisaxe, na actividade de incendios e na vulnerabilidade do sistema no seu conxunto. Tendo en conta esas incertezas, coméntanse a seguir os resultados de diversos estudos sobre algunhas desas cuestións.

A exploración das tendencias do perigo meteorolóxico de incendios en Galicia nun horizonte temporal dilatado (2010-2060) foi abordada en Vega et al. (2009b) no referido proxecto CLIGAL e en Arellano (2011). Comparáronse dúas aproximacións: unha na que simplemente se proxectaban no tempo as tendencias atopadas entre 1973 e 2006, no estudo xa comentado, e outra apoiada nunha simulación climática efectuada por MeteoGalicia para o período 2000-2060 (Martínez de la Torre e Míguez Macho 2009). Utilizouse nesta última o modelo HadCM3 da United Kingdom Met Office (UKMO) para o escenario SRES (Special Report on Emissions Scenarios; IPCC 2000) A1B, un contexto de emisións medio. Esa simulación xerou datos diarios das variables meteorolóxicas necesarias para alimentar os índices de perigo de incendios. Os principais resultados deses estudos foron os seguintes:

a) A diferenza do atopado para a media de Galicia no período 1973-2006 -cos índices construídos empregando datos reais das estacións meteorolóxicas-, 
todos os índices de perigo obtidos a partir dos datos da simulación climática mencionada mostraron unha tendencia significativa a empeoraren no período 2010-2060 (Táboa3). Esa distinta resposta fronte ao clima resultou máis aparente nos índices canadenses, nos que non se detectaron tendencias significativas de cambio, para a media de toda Galicia, no intervalo 1973-2006 (excepto no índice BUI). As pendentes relativas ás tendencias dos estimadores directos da humidade do combustible fino morto foron semellantes ás correspondentes ao primeiro período mencionado.

Táboa 3. Comparación dos valores e cualificación dos índices de perigo de incendios para a media estival de Galicia entre 2010 e 2060 baseados en: a) as tendencias calculadas a partir de datos meteorolóxicos reais entre 1973 e 2006, e b) valores obtidos por simulación climática entre 2000 e 2060 co modelo HadCM3 para un escenario de emisións medio

\begin{tabular}{|l|ll|ll|}
\hline Índice & \multicolumn{2}{|l|}{$\begin{array}{l}\text { Baseado nas respectivas tendencias obtidas } \\
\text { e datos meteorolóxicos reais entre }\end{array}$} & $\begin{array}{l}\text { Baseado nos valores respectivos obtidos de } \\
\text { simulación climática entre 2000-2060 }\end{array}$ \\
\cline { 2 - 5 } & $\mathbf{2 0 1 0}$ & $\mathbf{2 0 6 0}$ & $\mathbf{2 0 1 0}$ & $\mathbf{2 0 6 0}$ \\
\hline CBEF & Moderado & Alto & Moderado & Alto \\
& 10,4 & 8,8 & 11,2 & 9,2 \\
\hline FFMC & Baixo & Moderado & Moderado & Alto \\
& 80 & 84 & 83 & 87 \\
\hline DC & Moderado & Moderado & Moderado & Alto \\
& 380 & 410 & 403 & 535 \\
\hline BUI & Moderado & Moderado & Moderado & Moderado \\
& 52 & 49 & 53 & 108 \\
\hline
\end{tabular}

En termos prácticos, isto significa que ambos os métodos dan unha imaxe clara do empeoramento da situación de incendio, en canto ás condicións meteorolóxicas e á dispoñibilidade de combustible da cuberta morta do chan. Porén, a simulación climática ofreceu un cadro de maior perigo, en especial no que se refire á dificultade de extinción e aos efectos no chan. Este resultado concorda co atopado por Bedía et al. (2014) para o percentil 90 do índice FWI correspondente ao período 2071-2100, cunha simulación climática feita no escenario de emisións A1B. Parece, por tanto, que a extrapolación das condicións do período 1973-2006 podería non reflectir adecuadamente a situación futura, e que, á vista 
desa información (Táboa 3) para o conxunto de Galicia, podería ser considerablemente peor. Nun recente estudo de Bowman et al. (2017) a nivel global, baseado na análise dun conxunto de incendios de comportamento extremo e na aplicación dos ascensos obtidos por Bedía et al. (2014), prognosticábase para Galicia un aumento substancial no número de días en que se superaría o percentil 93 do FWI. Este resultado é moi preocupante porque podemos estar ante un escenario que se fai progresivamente máis desfavorable, como a comparación das tendencias de 1961-2006 e 1973-2006 apuntou.

b) Con todo, dado que a simulación climática proporcionou só un valor medio para Galicia e existen fortes diferenzas no perigo meteorolóxico ao longo do seu territorio, segundo se referiu, aplicouse a proxección baseada nas tendencias dos índices obtidas da serie meteorolóxica que vai de 1973 a 2006 a nivel provincial. Na Figura 6 obsérvanse as marcadas diferenzas en diferentes índices de perigo simulado de incendios, atopadas para A Coruña e Ourense, no horizonte 2010-2060, que se manifestan nun progresivo incremento do perigo na segunda desas provincias. Non obstante, é importante subliñar que, á vista do indicado máis arriba, pode tratarse dun cadro que estea subestimando o perigo.

c) Tamén, a media do número de días en que os índices canadenses estiveron no seu nivel alto para o conxunto de Galicia tendeu a aumentar significativamente entre 2000 e 2060. Iso supoñería, por exemplo, que os días en que o lume queimaría con alto DC (elevada sequidade no chan) no verán pasarían de 30 a 57 e que o número de días en que a consunción de combustible (BUI) estaría nun nivel alto cambiaría de 12 a 47, mentres que o FWI tería 15 días no seu nivel alto en 2000 e 49 en 2060. Nótese que, polo que vivimos en datas recentes, é posible que se trate dun escenario subestimador do perigo. Bowman et al. (2017), no estudo citado, predicían para Galicia un incremento do $40 \%$ dos días que presentarían valores extremos (percentil $93 \%$ ) do FWI.

d) Os índices de perigo determinados a través da simulación climática para o período 2000-2060 foron introducidos nos modelos preditivos do número anual de incendios e da área queimada en Galicia en función duns índices de perigo, achados previamente (Vega et al. 2009b). Obtívose así unha estimación da proxección deses parámetros de actividade de incendios para 2000-2060 que sinalaba un escenario de empeoramento. Como é obvio, estes resultados foron considerados só indicativos por varias causas: moderada variabilidade absorbida 

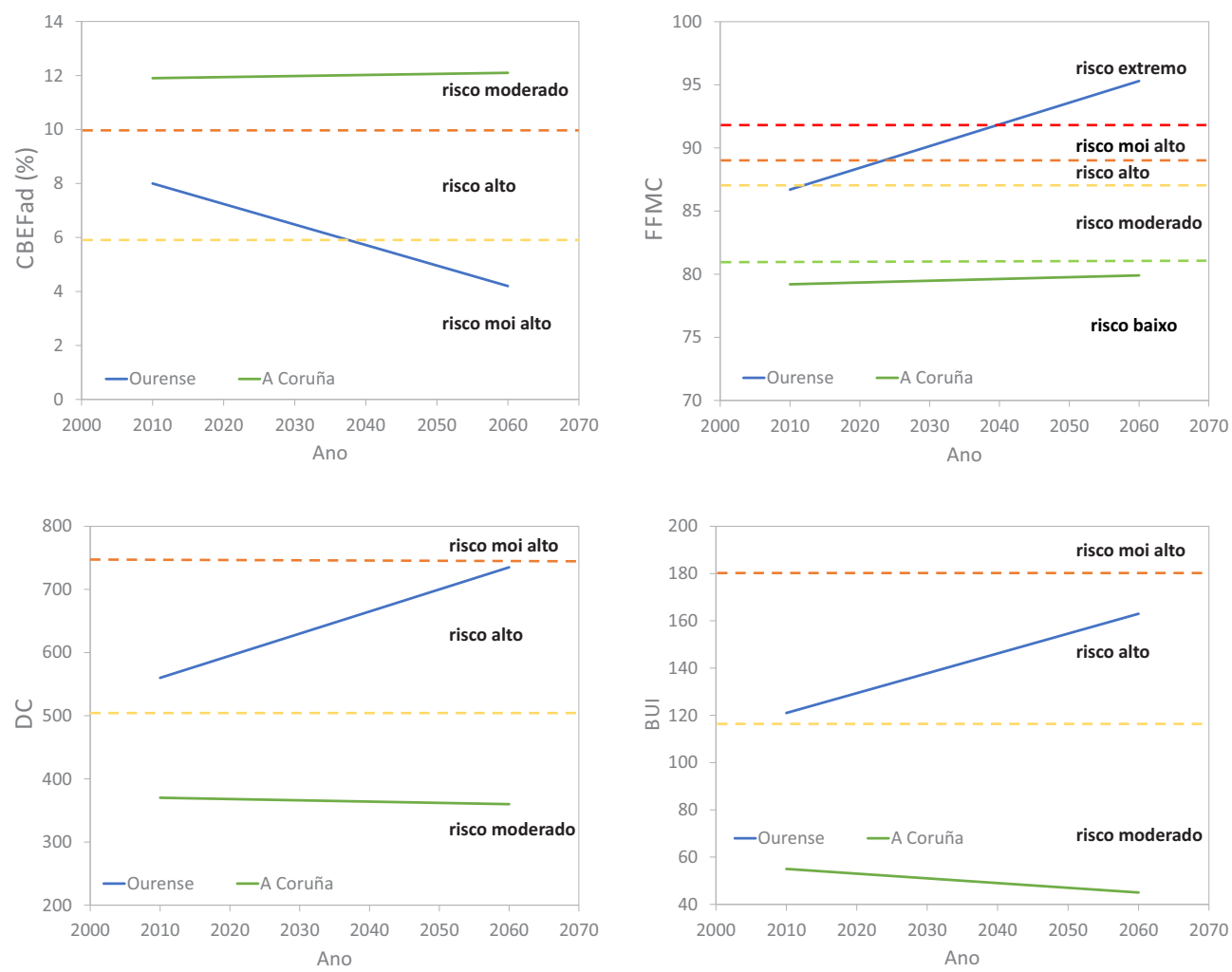

Figura 6. Simulación da variación dos niveis dos índices de perigo de incendios (período 2010-2060), para A Coruña e Ourense, obtida a partir das tendencias de cambio dos índices correspondentes ao intervalo 1973-2006. Os rangos de perigo para cada índice indícanse polas liñas horizontais e seguen os valores recomendados por Cruz (2000). Fonte: Vega et al. (2009b)

por eses modelos, elevada incerteza dos modelos climatolóxicos en xeral e, en particular, nunha área como Galicia, cunha variabilidade climática pronunciada. Non obstante, o maior factor de incerteza débese a cambios na compoñente socioeconómica, cunha alta capacidade para mudar con rapidez, o cal xerou por agora modelos que tamén absorben escasa variabilidade. De feito, a comparación dos valores preditos de área queimada cos observados realmente entre os anos 2000 e 2017 -período en que se inclúen as crises de 2006 e 2017- mostrou unha sobreestimación dun $23 \%$ na área queimada, o que é habitual ata agora con este tipo de predicións (Turco et al. 2018). Mentres tanto, o estudo de 
Sousa et al. (2015) atopou para a rexión formada por unha franxa que inclúe a parte occidental do centro e o norte de Portugal e toda Galicia, agás Lugo, que a superficie queimada no período 2006-2075 podería estar entre dúas e cinco veces a do período de referencia (1981-2005), tendo en conta as proxeccións climáticas e asumindo que se mantiveron as tendencias da actividade humana, da loita contra os incendios e do uso da terra. Pola contra, Jiménez-Ruano et al. (2020), dentro dun estudo xeral sobre as tendencias da activade de incendios na Península, predixeron para o período (2016-20536) un réxime de lume en Galicia similar, con dúas excepcións: o número de lumes no inverno, que tendía a aumentar, e os incendios de verán de tamaño medio-grande, para os que se esperaba un incremento.

En conxunto, os cambios atopados debuxan un cadro de elevada dificultade de extinción e no que o impacto nas edificacións, as infraestruturas, a vexetación e o chan, entre outros, aumentaría.

\section{OS NOVOS INCENDIOS XA ESTÁN A CHEGAR: PREVISIÓNS DESBORDADAS}

As proxeccións de perigo comentadas nas liñas superiores víronse excedidas por dúas novas situacións meteorolóxicas non ocorridas anteriormente en Galicia e norte de Portugal. Unha afectou ao centro-norte do país veciño e a outra a esa rexión e tamén a Galicia.

\section{Os grandes incendios de xuño de 2017 en Portugal}

Co seu ronsel de falecidos e destrución, estes incendios supoñen un exemplo de a que pode enfrontarse a nosa sociedade nos vindeiros anos. No informe do Parlamento de Portugal (Assembleia da República 2017) realizouse unha detallada análise do impacto das condicións meteorolóxicas no desenvolvemento deses incendios e no comportamento do lume. Aínda que non se entrou a avaliar directamente a influencia do cambio climático neses eventos, parece que este actuou sobre todo a través dunha seca anormalmente temperá, intensa e prolongada. Unha longa estación seca previa ao incendio e con temperaturas por encima da 
media, como o que ocorreu en 2017, pode inducir un grao de estrés hídrico considerable na vexetación, un acusado descenso da humidade no solo e unha forte perda de auga nos combustibles mortos grosos, o cal fai que estea dispoñible para o lume máis cantidade destes (Resco de Dios 2020). Tamén pode aumentar a continuidade do combustible, ao romper as «barreiras naturais» creadas pola vexetación de valgadas e zonas húmidas, o cal permite unha maior expresión do efecto das variables meteorolóxicas (Fernandes et al. 2016b). Malia que estas últimas non chegaron a alcanzar valores extremos, resultaron elevadas. Con todo, foi a interacción incendio-atmosfera -coa creación de pirocumulonimbos e a súa posterior esborrallada- a causante dun comportamento do lume extremo - «tormenta de lume»-, con velocidades de propagación, potencia e crecementos da área queimada ata agora non vistos en Europa. A extensión, a continuidade e a cantidade de combustible (cambios na cuberta vexetal) e o seu baixo nivel de humidade -efecto do cambio climático- foron considerados determinantes para a xeración dunha alta intensidade, o que posibilitou o desenvolvemento de potentes pirocumulonimbos nunha atmosfera previamente inestable (Assembleia da República 2017).

\section{Os grandes incendios de outubro de 2017 en Galicia e Portugal}

Os incendios acontecidos do 14 ao 16 de outubro no centro de Portugal (Assembleia da República 2018) e en Galicia xeráronse nunha situación meteorolóxica moi lonxe do usual, xa que estiveron baixo a anómala influencia das alteracións meteorolóxicas creadas pola proximidade do ciclón Ophelia. Este furacán desprazouse desde o Atlántico leste, onde se orixinou, subindo en latitude e bordeando Portugal e Galicia. Produciu unha advección de ar quente e seco de África, que deu lugar a diversos períodos de alta temperatura, baixa humidade do aire e fortes ventos co efecto foehn de compoñente S-SW-SE. A este cadro hai que engadir o efecto dunha previa seca prolongada. Os valores dos índices de perigo en Vigo (Táboa 4) e Celanova (Táboa 5) para os días 14 ao 16 de outubro ilustran ben a situación. A maioría deles oscilan entre valores moi altos e extremos, e o efecto do vento o día 15 é máis pronunciado en Vigo. O índice FWI alcanzou valores extremos nos días 14 e 15, pero foi aínda alto o 16 en Ourense. Os valores dos índices DMC, DC e BUI reflicten o efecto da seca, máis pronunciada en Ourense. 
Táboa 4. Valores ás 13:00 UTC de varios índices de perigo meteorolóxico de incendios calculados sobre a base dos datos da estación meteorolóxica de Vigo-Campus para os días que van do 14 ao 17 de outubro de 2017. Fonte: MeteoGalicia

\begin{tabular}{|l|l|l|l|l|}
\hline & Día 14/10/2017 & Día 15/10/2017 & Día 16/10/2017 & Día 17/10/2017 \\
\hline Precipitación, mm & 0 & 0 & 1,2 & 13,6 \\
\hline CBEF & 8,3 & 6,5 & 16,7 & 14,3 \\
\hline GFDM & 6,3 & 4,9 & 16,8 & 14,3 \\
\hline FFDM & 4,9 & 4,2 & 17,9 & 10,2 \\
\hline FFMC & 95 & 95 & 78,5 & 58 \\
\hline ISI & 12,5 & 36 & 1,3 & 1,1 \\
\hline BUI & 126 & 132 & 133 & 74 \\
\hline DMC & 83 & 87 & 87 & 44 \\
\hline DC & 694 & 699 & 703 & 606 \\
\hline FWI & 40 & 78 & 7 & 4 \\
\hline
\end{tabular}

Táboa 5. Valores ás 13:00 UTC de varios índices de perigo meteorolóxico de incendios calculados sobre a base dos datos da estación meteorolóxica de Celanova para os días que van do 14 ao 17 de outubro de 2017. Fonte: MeteoGalicia

\begin{tabular}{|l|l|l|l|l|}
\hline & Día 14/10/2017 & Día 15/10/2017 & Día 16/10/2017 & Día 17/10/2017 \\
\hline Precipitación, mm & 0 & 0 & 0 & 10 \\
\hline CBEF & 6,1 & 5,9 & 9,1 & 10,7 \\
\hline GFDM & 4,7 & 4,7 & 7,1 & 8,8 \\
\hline FFDM & 4,1 & 4,1 & 5,4 & 6,2 \\
\hline FFMC & 94 & 94 & 90,0 & 66 \\
\hline ISI & 6,0 & 6,5 & 6,4 & 1 \\
\hline BUI & 185 & 189 & 191 & 116 \\
\hline DMC & 136 & 140 & 142 & 73 \\
\hline DC & 723 & 730 & 734 & 700 \\
\hline FWI & 39 & 49 & 27 & 5 \\
\hline
\end{tabular}

Especialmente grave foi a marcada simultaneidade de baixa humidade relativa e elevada temperatura do aire, en conxunción cunha alta velocidade do vento, entre as 14 e as 20 h do día 15 no sur da provincia de Pontevedra. Só nese día 
houbo 124 ignicións en Galicia (Cela 2018), cun total de 247 incendios nos días 14, 15 e 16. No sur de Pontevedra, á media tarde do día 15 a humidade calculada do combustible fino morto estaba nun $6 \%$ e a velocidade media do vento na estación meteorolóxica de Vigo-Campus roldaba $30 \mathrm{~km} / \mathrm{h}$, con refachos que oscilaban entre 40 e $78 \mathrm{~km} / \mathrm{h}$. Esta velocidade media foi superior ao percentil 97 da serie histórica entre 1973 e 2006 para o aeroporto de Vigo. Os lumes estendéronse a gran velocidade, principalmente conducidos polo vento. En varias simulacións feitas con modelos de combustible de eucaliptais da zona, con moderada carga de matogueira, para unha pendente do $20 \%$ (Arellano et al. 2017), calculáronse nesas horas velocidades de propagación de entre 1 e $2 \mathrm{~km} / \mathrm{h}$, que xeraban potencias lineais, na cabeza dalgúns destes incendios, superiores a $20000 \mathrm{~kW} / \mathrm{m}$. A velocidade resultou entre tres e cinco veces menor nas plantacións de eucalipto nas que se mantén o sotobosque tratado, e a potencia entre catro e sete veces inferior. Os valores indicados son compatibles cos observados polo Servizo de Prevención e Defensa contra Incendios Forestais de Pontevedra (Francisco, comunicación persoal, 2019) no incendio de Padróns-Ponteareas e consistentes coa velocidade media de propagación do lume para a totalidade dese incendio, de arredor de $12 \mathrm{~m} / \mathrm{min}$ (Cela, 2018).

No caso dos piñeirais, cos cálculos que se elaboraron segundo os modelos citados, prognosticáronse para os latizais frecuentes carreiras de lume de copa con velocidades considerablemente altas, de arredor de $3 \mathrm{~km} / \mathrm{h}$, e potencias lineais na cabeza do incendio que excedían os 35000 ou $40000 \mathrm{~kW} / \mathrm{m}$. Mentres tanto, nos fustadíos, principalmente cun sotobosque de frouma e fento, eses valores variaron entre 0,3 e $0,6 \mathrm{~km} / \mathrm{h}$, cunhas potencias lineais entre 6 e 25 veces máis baixas. Por último, para toxeiras de $1 \mathrm{~m}$ de altura e pendentes do $20 \%$, as velocidades calculadas estiveron entre 2 e $3 \mathrm{~km} / \mathrm{h}$, con potencias de, polo xeral, entre 20000 e $30000 \mathrm{~kW} / \mathrm{m}$. Obviamente, a maioría desas situacións quedaron fóra da capacidade de extinción dun ataque ampliado frontal. A pronunciada inclinación da columna de convección observada durante a mañá e a tarde do día 15 indicou unha propagación dominada polo vento (Rothermel 1991). Isto concorda con outros cálculos comparativos efectuados sobre a potencia do vento e a do lume (Byram 1959b, Nelson 1993), nos cales a maior parte do tempo dominou a primeira delas, e coa forma da área queimada (Figura 7). En conxunto, aínda que se desenvolveron pirocumulonimbos en determinados momentos, 
non adquiriron as dimensións dos orixinados nos incendios de xuño en Portugal nin se produciu a esborrallada deles. Algúns dos incidentes de Galicia estiveron na categoría 2, de incendios extremadamente grandes ( $>2500$ ha), suxerida por Fernandes et al. (2014).

Por outra banda, moitos destes incendios da zona oeste galega xeraron escenarios en que predominou unha severidade do lume moderada (Figura 7), en principio non esperable, dada a elevada intensidade lineal do incendio e a sequidade do solo. Esta resposta produciuse por propagarse o lume sobre todo a través de eucaliptais, que, debido á elevada altura media da base da copa, non resultan tan propicios para o lume copa como os piñeirais. Ademais, algunhas zonas de eucaliptal eran de plantacións ben xestionadas, con combustibles do estrato superficial tratados, o que restou potencia ao lume. De calquera forma, o rápido avance do lume, propiciado pola emisión de faíscas -máis frecuentes en eucaliptais- e a creación de numerosos focos secundarios, logo da súa aterraxe e da ignición duns combustibles sumamente secos, deixou numerosas «illas verdes» pequenas sen arder. Por exemplo, na Figura 7 pódese ver que a porcentaxe da área non queimada dentro do perímetro da área cuberta polo lume foi $11,9 \%$, e un $22,8 \%$ a suma do anterior e dunha severidade baixa, mentres pouco máis da metade da superficie afectada polo lume (55,8 \%) tivo unha severidade alta e moi alta. Estas cifras foron moi similares para todos os incendios daqueles días na provincia de Pontevedra (Picos et al. 2019) e aínda Ourense (Chas-Amil et al. 2020), que xeraron áreas queimadas con severidade baixa a moderada na súa maioría. Ademais, a alta velocidade do lume deu lugar a unha penetración da calor no solo menor que noutros incendios máis lentos. Iso resulta nunha severidade do lume nos estratos orgánicos e o solo superficial inferior á esperada nun principio a teor da baixa humidade do humus e do solo, reflectidos polos indicadores DMC e DC. De feito, Sobrino et al. (2019) observaron que a severidade media do lume nos solos do incendio de Padróns-Ponteareas (Pontevedra), medida en áreas onde a severidade do lume na vexetación foi moi alta-extrema, tivo un valor medio moderado. 


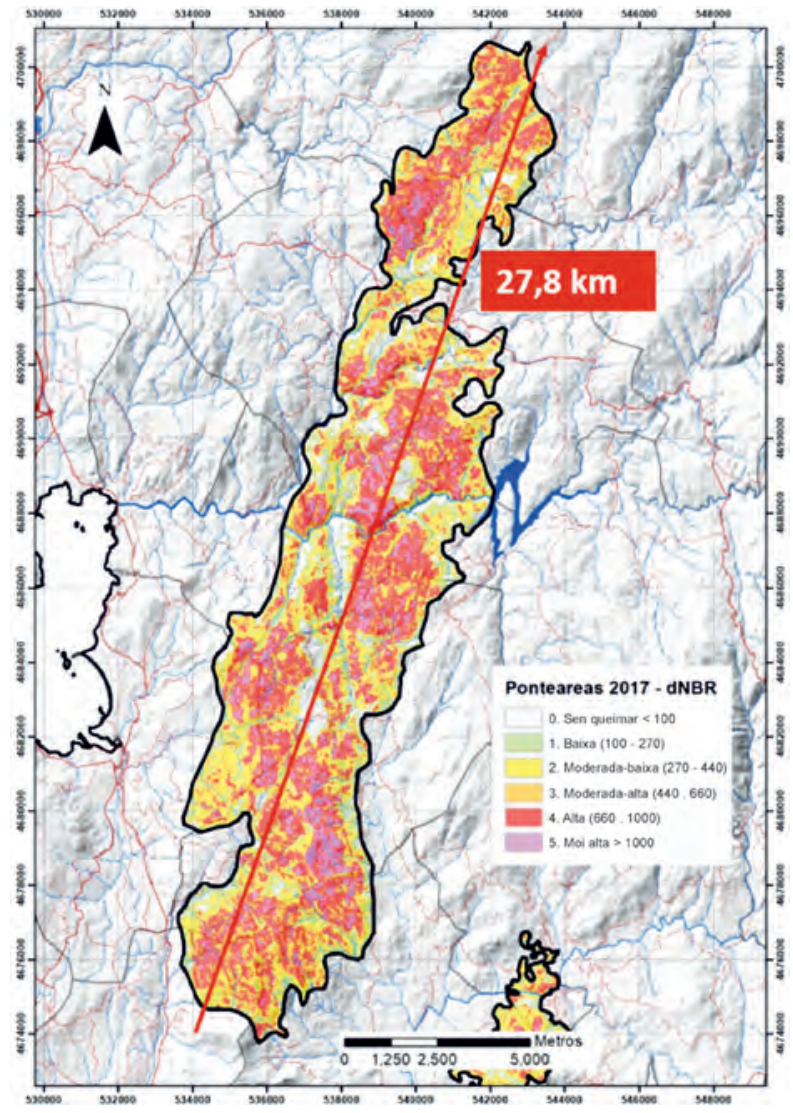

IF Padróns - Ponteareas

Día inicio: 15/10/2017

Hora inicio: 00:26

Superficie $=\mathbf{8 8 9 2}$ ha
Porcentaxe de superficie queimada para cada nivel de gravidade

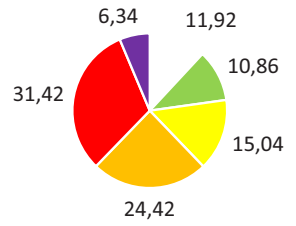

dNBR_sq_por - $d$ dNBR_baixa_por =dNBR_mod_baixa_po

Figura 7. Imaxe da severidade do lume no incendio de Padróns, en Ponteareas (Pontevedra), mediante o índice espectral dNBR obtido de información do satélite Landsat-8, e porcentaxe da área queimada afectada polos diferentes niveis de severidade do lume. $\mathrm{sq}=$ sen queimar, baixa= baixa severidade, mod. baixa $=$ severidade baixa a moderada, mod. alta $=$ severidade moderadamente alta, alta $=$ severidade alta, moi alta $=$ severidade moi alta

\section{O CAMBIO CLIMÁTICO NO POSTINCENDIO}

Varias consecuencias dos incendios poden verse magnificadas ou reducidas polas alteracións climáticas, aínda que, como se indicou, subsiste unha elevada incerteza respecto ás tendencias de moitos dos parámetros climáticos. A subida da temperatura media en arredor de $1,5^{\circ} \mathrm{C}$ cara á metade do século actual en 
Galicia, xunto a un descenso das precipitacións na primavera (Martínez de la Torre e Míguez Macho 2009), implicaría unha maior sequidade na vexetación, o que propiciaría un estrés hídrico nela. Este induciría unha maior mortalidade directa da vexetación causada polo incendio e o seu enfraquecemento que podería afectar á súa capacidade de recuperación postincendio (Resco de Dios 2020). Tamén o recrutamento de novos individuos, a partir de semente e mesmo de cepa, podería verse prexudicado, o cal limitaría a rexeneración natural da vexetación despois do incendio (Vega 2003). Este descenso da resiliencia da vexetación ao lume, debido ao cambio climático, é considerado un perigo crecente en moitos ecosistemas (Stevens-Rumman et al. 2018). A conxunción de maior aridez poslume, tras lumes máis frecuentes, podería inducir á perda da cuberta arbórea e favorecer un proceso de conversión en matogueiras, como é evidente xa en moitos lugares de Galicia (Regos et al. 2014) e foi ben documentado noutras partes da Península (Pausas 1999, Díaz-Delgado et al. 2002, Lloret et al. 2003, Rodrigo et al. 2004, Espelta et al. 2008, Moreira et al. 2011, Taboada et al. 2017, Fernández-García et al. 2019, Baudena et al. 2019). Ao mesmo tempo, a sequidade máis alta da cuberta orgánica e o solo antes do incendio propiciaría unha maior gravidade do impacto do incendio no solo (Fernández Filgueira et al. 2013, Vega et al. 2013a e 2013b, Fontúrbel et al. 2017a, García-Oliva et al. 2018, Merino et al. 2018), coas consecuencias de maior degradación e maior susceptibilidade á erosión pluvial tras o incendio en Galicia (Fernández e Vega 2016a). A xestión da vexetación queimada ten tamén repercusión na súa rexeneración (Vega et al. 2008 e 2010a, Fernández et al. 2008, Fernández e Vega 2016b) e podería reforzarse o seu efecto debido ao clima posterior ao lume.

Con todo, as proxeccións climáticas non son conclusivas respecto á futura distribución da choiva no outono en Galicia. Así, mentres Cruz et al. (2009) apuntaron a un incremento da choiva outonal, concentrada en menos días, Álvarez et al. (2011 e 2012) presentaron un cadro máis impreciso. Se o cambio global promove un maior crecemento, non planificado, da interface urbano-forestal, é probable que nos próximos anos o risco de danos hidrolóxicos postincendio á poboación sexa máis elevado. 


\section{AIGUNHAS CONSIDERACIÓNS E PROPOSTAS DE ADAPTACIÓN AO NOVO ESCENARIO}

Factores do cambio global como o crecemento e continuidade da superficie forestal, a expansión das especies produtivas inflamables e as matogueiras, o absentismo do silvicultor e o abandono da actividade agraria foron actuando en Galicia desde hai xa bastantes décadas. Mentres tanto, aínda que a vexetación arbórea autóctona, pouco inflamable, tamén aumentou nese período, continuou presentando unha superficie fragmentada e insuficiente para influír, a nivel da paisaxe, na ralentización da propagación do lume nos grandes incendios. Polo que respecta ao cambio climático, a información comentada mostra que se foron producindo, polo menos desde principios dos setenta, un adianto e unha maior duración da época de perigo de incendio en Galicia, asociados a un empeoramento nas condicións meteorolóxicas, que afectan ao comportamento e efectos do lume. O resultado foi un progresivo incremento da facilidade para a propagación do lume e da potencia dos incendios, o cal, unido aos cambios socioeconómicos habidos, fixo crecer o perigo para a poboación e aumentar a gravidade dos danos causados. A isto cabe engadir a maior recorrencia do lume en numerosas áreas forestais, que intensificou eses impactos e dificultou a rexeneración natural dos ecosistemas afectados, que viña sendo anteriormente boa, en xeral, en Galicia. O resultado desa recorrencia foi a transformación de numerosas áreas forestais de fustadíos en latizais e en matogueiras, implicando non só unha perda de recursos senón tamén a miúdo a degradación dos servizos ecosistémicos proporcionados polas formacións arbóreas (Vega, 2003) e un maior perigo dos combustibles. Esta situación pode agravarse no futuro, polas probables condicións máis adversas para a rexeneración postincendio, debido ao cambio climático, e a persistente tendencia a diminuír o período de retorno do lume en moitos montes galegos.

Os efectos do cambio global gañaron en visibilidade desde ao redor de 2006, debido a que as mudanzas nos combustibles e na interface urbano-forestal estaban moi consolidadas e, sobre todo, a que nos momentos de condicións meteorolóxicas máis desfavorables as pautas de ignición humana foron máis agresivas. Dado que unha das características do cambio climático é o incremento esperado dos eventos meteorolóxicos extremos (Jentsch e Beierkuhnlein 2008, Planton et 
al. 2008, Smith 2011, IPCC 2014), desafortunadamente cabe esperar que os episodios de incendios como o sufrido en outubro de 2017 poidan ser máis frecuentes no futuro.

Ata agora o sistema de protección contra incendios forestais puido facer fronte nun tempo moi breve á gran maioría das situacións en Galicia. Con todo, existe incerteza respecto a se nos decenios vindeiros vai dar afrontado con éxito as consecuencias dun incremento sostido das condicións que propician un novo tipo de incendios, non só de grande extensión, senón tamén de comportamento moito máis virulento -e con episodios de forte simultaneidade de focos-, afectando áreas densamente poboadas, problema común a moitas rexións e países (Piñol et al. 2007, Podur e Wotton 2010, Moreira et al. 2011, Rodrigues et al. 2019a). Non obstante, é importante subliñar que ningún sistema de extinción existente no mundo pode facer fronte con éxito inmediato aos eventos de comportamento extremo do lume forestal, como os ocorridos en 2006 e 2017 en Galicia. Ante condicións meteorolóxicas extremas, os sistemas de extinción ou non poden operar ou son sistematicamente desbordados temporalmente (Brotons et al. 2013, San Miguel-Ayanz et al. 2013, Fernandes et al. 2016c, Tedim et al. 2018, Rodrigues et al. 2019b e 2020). Aínda máis, xunto a un escenario caracterizado pola conxunción dun cadro climático desfavorable, con combustibles perigosos e en cantidades altas, e dentro dun complexo e cambiante escenario socioeconómico, temos en Galicia outros agravantes que enfrontar. Por unha banda, hai moitas ignicións de accións incendiarias e neglixencias, coincidentes con condicións meteorolóxicas extremas, e, por outra, subsisten tensións e conflitos non resoltos entre parte dos actores involucrados. No seu conxunto, o anterior non resulta o panorama máis favorable para encarar de maneira satisfactoria un problema crónico que, a partir de agora, corre o risco de facerse máis dificilmente gobernable.

En moitas rexións do mundo cun problema similar estase asumindo que son necesarias modificacións moi notables na estratexia da xestión do lume, en xeral, e de loita contra os incendios forestais, en particular, para adaptarse a un novo escenario de cambio global (Moritz et al. 2014, Olson et al. 2015, Thompson et al. 2015 e 2019) e iso é tamén necesario en Galicia. Mesmo así, non podemos perder de vista un aspecto esencial na nosa situación particular: as condicións meteorolóxicas desfavorables son necesarias para que se produzan 
os megaincendios, pero non son suficientes. $\mathrm{Na}$ maioría das veces requírese a intervención humana para conseguir crealos. Dado que a frecuencia de episodios meteorolóxicos extremos é probable que aumente no futuro, o problema das ignicións, e particularmente das coincidentes cos eventos meteorolóxicos extremos, as «vagas de lume», é un problema de envergadura ante o que a nosa sociedade necesita reaccionar, mellorando a investigación de causas e solucionando os conflitos existentes que poidan facilitar comportamentos asociais. Porque non pode esquecerse que hai un trazo moi preocupante nos novos megaincendios do século XXI en Galicia. Durante a década dos noventa superáronse os dez mil incendios en varios anos e a superficie queimada máis grande tivo lugar en 1989, cunhas 198000 ha, pero ardeu maioritariamente nas zonas de monte e non se produciron crises como as do 2006 e o 2017, nas que se tivo un número de incendios bastante menor pero con moitos máis danos e alarma á poboación. Unha diferenza substancial entre estas dúas situacións coa precedente de 1989 estivo na concentración espacial dos lumes e no elevado nivel de impacto na interface urbano-forestal nos dous episodios máis recentes, coincidindo con condicións meteorolóxicas graves (Balsa-Barreiro e Hermosilla 2013, Boubeta et al. 2015, Chas-Amil 2007). Por exemplo, nos incendios de 2017, Chas-Amil et al. (2020) determinaron que máis de 80000 edificios e 85000 persoas estiveron a menos dun $\mathrm{km}$ dun incendio. Ese aumento do número de persoas expostas ao lume introduce un novo elemento na estimación do risco da poboación durante o incendio, o que xera moita complexidade na tarefas de extinción, e tamén na avaliación dos impactos do incendio. Require tamén unha nova cultura na poboación en termos de autoprotección e de mellor comprensión do risco dos lumes, e tamén de novos consensos sociais.

Dado o carácter de risco sistémico do incendio forestal en Galicia, fai falta unha visión transdisciplinar que considere ese risco dunha maneira máis integral (Ager et al. 2015 e 2017, Paton et al. 2015, Tedim et al. 2015, 2016 e 2019, Thompson et al. 2019), en conexión cos diferentes usos da terra, e onde os aspectos socioeconómicos e ecolóxicos sexan máis tidos en conta. Medidas «transversais» que coordinen accións preventivas entre organismos públicos con competencias no territorio son requiridas con urxencia. Iso significa que a prevención ten que estar no substrato de moitas accións lexislativas e de xestión diaria. 
Moitos países están enfrontándose a situacións similares de risco sistémico, debido a incendios forestais, nestes últimos anos. Iso está a implicar a necesidade de cambios de estratexias na resposta aos lumes, non só na extinción dos incendios senón tamén na nosa consideración do lume cunha perspectiva máis ampla. Un verdadeiro cambio de paradigma está a ser preconizado desde a ciencia, que supón pasar dun baseado moi principalmente na loita contra o incendio a outro fundamentado nunha visión máis integral do lume, a súa conexión coa sociedade, e na adaptación á nova situación global (Tedim et al. 2019, Tedim e Leone 2020). Iso implica que tanto a sociedade como as organizacións de xestión de incendios deben colaborar máis estreitamente nesa resposta, comprender mellor o papel ecolóxico do lume e aceptar que a erradicación do lume non só non é posible senón que non é desexable ecoloxicamente. Iso representa un reto moi forte. En casos como o de Galicia, onde persiste un elevado número de ignicións e de intencionalidade non suficientemente aclarada en moitos lumes, requírese tamén un esforzo adicional para manter un dispositivo de extinción forte e profesionalizado ao tempo que as outras consideracións dos lumes precisan, así mesmo, unha atención moi especial.

A nova aproximación parte de que é preciso comezar por aceptar que nas rexións densamente habitadas desde a antigüidade e, polo tanto, onde o ambiente «natural» estivo, e continúa a estar, profundamente alterado e xestionado polo home, constitúen, de feito, sistemas humanos-naturais asociados (Liu et al. 2007). Iso significa que estes complexos sistemas socio-ecolóxicos ou socio-ambientais caracterízanse por estar fortemente conectados, de xeito que as accións dunha parte afectan fortemente á outra (Liu et al. 2007, Prior e Eriksen 2013, Butsic et al. 2015). Máis aínda, as rexións propensas ao lume son consideradas un exemplo paradigmatico de desaxustes neses sistemas (Spies et al. 2014, Steelman et al. 2016). Este é o caso de Galicia, cos trazos xa comentados. Esa situación é ás veces considerada como unha disfuncionalidade ou patoloxía socio-ecolóxica (Fischer et al. 2016). Esixe, por unha banda, cambios adaptativos das organizacións con responsabilidade de xestión territorial e na xestión do lume, baseada ata agora na extinción, e, por outra, da sociedade no seu conxunto e dos individuos.

Actualmente hai un amplo consenso científico sobre a necesidade de adaptarse á nova situación creada polo cambio global e corrixir a difuncionalidade na 
relación entre a sociedade e o lume, o que implica aprender a convivir co lume (p. ex. Birot 2009, Moritz et al. 2014, Rego e Silva 2014, North et al. 2015, Tedim e Leone 2017, Schoennagel et al. 2017, Dunn et al. 2020), entre outras modificacións de estratexia. Este consenso debe tamén chegar gradualmente á sociedade, aos organismos que xestionan o territorio e ás organizacións implicadas na xestión dos incendios. A súa materialización é, con todo, complexa (Howitt 2014), xa que require cambios de mentalidade na poboación (Edwards e Gill 2016, Hamilton et al. 2018), líderes políticos e na estratexia do sistema xeral de xestión de incendios, e non está exenta de dificultade (North et al. 2015, Tedim et al. 2019, Hamilton et al. 2019, Steelman 2016, Thompson et al. 2015, Finney 2020).

Nese sentido, é necesario mellorar a comunicación do problema á sociedade, para propiciar unha comprensión máis real da situación vindeira, promovendo unha maior responsabilidade no uso do lume, así como o desenvolvemento dunha cultura de autoprotección. É moi importante crear unha sociedade consciente e informada dos riscos asociados ao lume, e autoprotexida, pero que ao mesmo tempo conte co lume como un elemento máis do sistema socio-ecolóxico no que está inmersa, que se sinta concernida co problema e contribuínte activa nas decisións tomadas polos xestores públicos (Everett 2002, Tábara et al. 2003, Hernando et al. 2012, McCaffrey et al. 2013, Marino et al. 2014, Tedim et al. 2016 e 2019). É preciso, polo tanto, facilitar a participación social e o consenso político sobre o tema porque, en definitiva, se trata dun problema colectivo complexo, que ten as súas raíces na nosa sociedade e lle corresponde a ela o principal papel na súa resolución (Tedim et al. 2015 e 2016, Bruña e Marey 2013 e 2017, Marey et al. 2015).

Así mesmo, necesitamos que esas ideas se transfiran no eido educativo a todos os niveis (Pardellas et al. 2018). Por exemplo, os contidos actuais dos textos escolares parecen estar contribuíndo pouco a un axeitado enfoque dos incendios. De feito, só transmiten unha imaxe negativa do lume. A miúdo mostran un moi baixo nivel de coñecementos ecolóxicos e técnicos e mesmo tendenciosos, con ideas despectivas sobre a actividade forestal produtiva, e desconectados da realidade social. Iso parece irónico nunha comunidade como Galicia, onde o conxunto da actividade industrial asociada ao sector forestal representa a terceira achega máis importante ao valor engadido bruto (VEB) industrial galego, e o 
sector forestal un importante xerador de emprego (Picos 2018). A necesidade de entender que o lume desempeña un papel ecolóxico e que os seus efectos teñen aspectos positivos e negativos, diferenciar os efectos ambientais dos incendios de alta severidade dos do uso correcto do lume, aprender a convivir co lume e aceptar que maioría dos incendios forestais non son unha emerxencia son algúns exemplos de aspectos relativos aos lumes que necesitan ser transmitidos correctamente á sociedade. Os medios de comunicación poden desempeñar así mesmo un papel moi importante, axudando a crear unha cultura do lume máis axustada á súa realidade dual, que hoxe é considerada a máis axeitada no eido científico. Un bo nivel de preparación dos profesionais dedicados á transmisión da información relacionada cos incendios é decisivo, dada a súa forte influencia na resposta da poboación ao lume. Tamén un esforzo por utilizar fontes obxectivas (Xanthopoulos 2008, Delgado Arango et al. 2018). Ao mesmo tempo, a Administración debe contar con equipos profesionais que comuniquen a información relativa aos lumes forestais con coñecemento, transparencia e rapidez.

Crear espazos «defendibles» ao redor dos núcleos habitados e velar polo seu mantemento e operatividade son, sen dúbida, labores urxentes e necesarios para a protección da vida humana e infraestruturas, pero eses espazos deben establecerse con criterios flexibles que permitan modular as súas características en función do risco local (Elia et al. 2014). O seu deseño, xestión e especialmente o seu mantemento supoñen importantes retos, non só económicos senón de transformación da paisaxe e recuperación de usos alternativos da terra (Moritz et al. 2014). Por outra banda, é preciso fomentar a responsabilidade e a cooperación dos propietarios forestais e institucións e diversos grupos sensibilizados para desenvolver unha xestión silvícola adecuada que reduza a ameaza actual duns combustibles parcialmente descontrolados. Sería necesario incentivala con axudas ao asociacionismo e ao emprendemento (Chas-Amil et al. 2015, Parlamento de Galicia 2018, Fischer e Charnley 2012, Alló e Loureiro 2016). No caso de Galicia, con multitude de pequenas propiedades abandonadas, onde os combustibles supoñen un elevado perigo para as zonas circundantes, son necesarias medidas que faculten á Administración para velar pola protección do conxunto da sociedade.

O apoio da ciencia na xestión do lume (Pyne 2007), axudándoa a conectar mellor coas necesidades sociais e económicas da comunidade (FAO 2008, 2011 
e 2012), é tamén moi necesaria (Thompson et al. 2015 e 2018, Dunn et al. 2020).

Precísase con urxencia, na xestión do lume forestal, combinar o paradigma da extinción sempre e incondicional co dunha prevención máis activa e participativa, para ir definitivamente potenciando a segunda. Iso tería que realizarse no marco dunha ordenación de usos do territorio máis integrada que a ata agora, levada a cabo de xeito moi sectorial (Collins et al. 2013). Non obstante, ese cambio ten que efectuarse progresivamente en territorios como Galicia e, á vista dos resultados, mentres subsista un número elevado de lumes incontrolados.

O tema dos incendios é o suficientemente complexo como para que non se poidan establecer receitas sinxelas e xerais. Unha gran cantidade de achegas e propostas están emerxendo nos últimos anos respecto á mellor estratexia que seguir fronte aos incendios do cambio global, vindo tanto de organismos públicos como de grupos de investigación (p. ex. Wildland Fire Leadership Council 2014, European Commission 2018, Comité de Lucha contra Incendios Forestales 2019, Tedim et al. 2019, Alcasena et al. 2019, Bowman et al. 2020, Moreira et al. 2019). A título de exemplo, na Figura 8 indícanse os principais campos de accións que acometer antes, durante e despois do incendio suxeridos pola proposta de Tedim et al. (2019). Está baseada nos principios de xestión do risco, aceptación do papel ecolóxico do lume e a participación social; defende o cambio de paradigma, desde loitar contra o lume a progresar co lume.

$\mathrm{Na}$ situación de Galicia, unha estratexia baseada no uso combinado da protección total en áreas críticas, restauración parcial ordenada do uso do lume e unha extinción matizada, na liña do recomendado por Pyne (2015), podería presentar problemas, dada a presión demográfica e o alto número de ignicións de causa descoñecida. A implementada actualmente nos Estados Unidos de Norteamérica, consensuada entre organismos públicos, organizacións non gobernamentais e comunidades (Figura 9), supón un cambio notable aínda que está presentando dificultades e atrancos para a súa plena implementación. Alcasena et al. (2019) suxeriron unha aproximación similar para o NE de España. Nun escenario social, cultural e bioxeográfico máis próximo a Galicia, Moreira et al. (2019) defenden para Portugal un cambio da extinción pola mitigación e adaptación, aceptando a inevitabilidade do lume no contexto de cambio global. Eles propoñen reequilibrar os gastos entre as accións de apagar o lume e reducir 
Estimación das perdas e necesidades

\section{Postincendio}

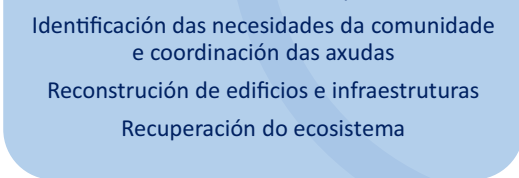

Durante o incendio

Crise de comunicación

Actividades de combate do lume

Necesidades da comunidade

Figura 8. Accións principais que desenvolver antes, durante e despois do incendio segundo a proposta de cambio de paradigma na xestión dos incendios forestais, segundo Tedim et al. (2019)

os impactos sociais e ecolóxicos negativos dos incendios de alta severidade. Aquí, mitigación refírese ás accións anticipativas (preventivas no sentido amplo) dos efectos negativos dos incendios. A súa proposta baséase en dous puntos clave. O primeiro busca promover cambios no territorio que o fagan menos vulnerable e máis resiliente, baseado nas ideas de «paisaxes intelixentes» (Hirsch et al. 2001, Fernandes et al. 2013, Tedim et al. 2016, Castellnou et al. 2019, onde os cultivos agrícolas, o pastoreo e o silvopastoreo creen descontinuidades nos combustibles a escala de territorio. $\mathrm{O}$ segundo céntrase en reducir o risco para os humanos e as infraestruturas, mediante tratamentos de combustible estratéxicos (Ager et al. 2010 e 2017). Ás infraestruturas habería que engadir en Galicia certos servizos ecosistémicos críticos, como a calidade da auga e a conservación dos solos, entre outros. 


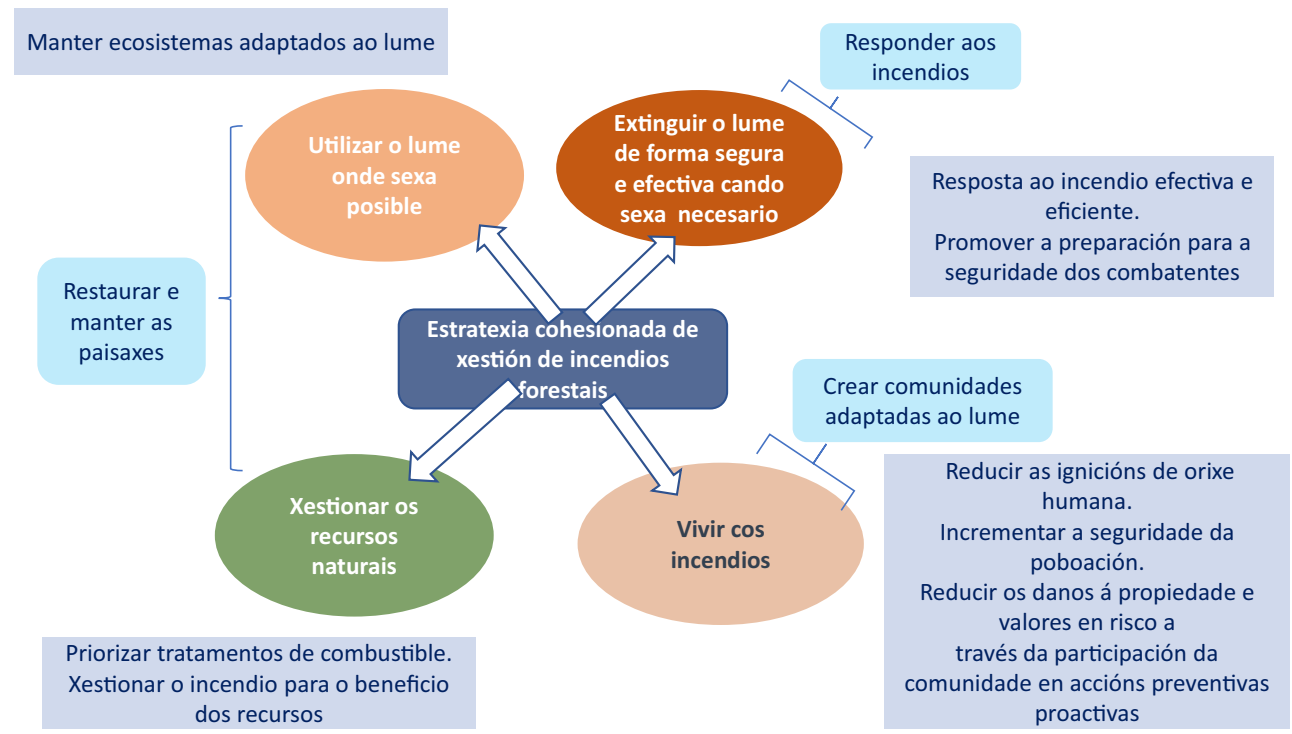

Figura 9. Os catro eixes directrices da actual estratexia cohesionada nacional de xestión dos lumes forestais nos Estados Unidos de América (Wildland Fire Leadership Council 2014).

En azul claro os obxectivos principais. En gris claro os principais desafíos

O Comité de Lucha contra Incendios Forestales, un marco de coordinación que agrupa aos organismos de defensa contra incendios das comunidades autónomas en España, propuxo recentemente (Ministerio de Agricultura, Pesca y Alimentación 2019) unha nova estratexia baseada en seis obxectivos (Figura 10). Pódese ver que considera a maioría dos principios comentados liñas máis arriba.

A volta a un mosaico agroforestal de usos tradicionais da terra parece desexable desde o punto de vista da defensa contra lumes catastróficos e inscríbese no contexto de "paisaxes intelixentes». Foi proposta hai algúns anos (Loepfe et al. 2010) e máis recentemente amplamente preconizada (Fernandes et al. 2014, Castellnou et al. 2019, Aquilué et al. 2020, Campos et al. 2020, Moreira et al. 2019, Pais et al. 2020), máis ou menos asociada a unha proposta de nova agricultura de alto valor cultural e máis respectuosa co medio natural. Por exemplo, no incendio catastrófico de Pedrogão Grande (Portugal), Tedim et al. (2018) detectaron que as manchas de terreo non queimadas correspondían principalmente a zonas onde a interface urbano-forestal e a vexetación coexistían. A maioría destas 


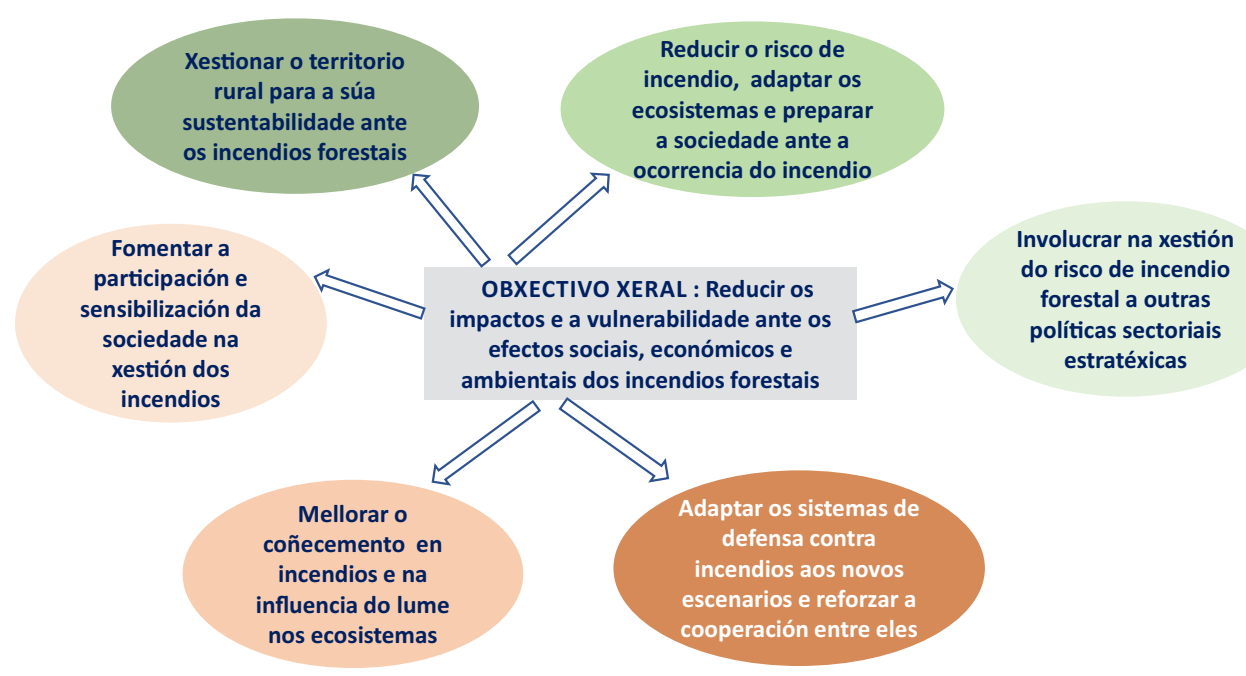

Figura 10. Obxectivo xeral e parciais da estratexia de xestión dos incendios forestais proposta polo Comité de Lucha Contra Incendios Forestales (MAPA, 2019)

zonas constaban de asentamentos humanos rodeados de terras agrícolas, ás veces asociadas a pequenas masas de caducifolias, tamén a pequenas manchas de plantacións de eucalipto moi novas e de especies caducifolias próximas aos ríos. Esas manchas non queimadas atopáronse menos frecuentemente en plantacións adultas de eucalipto. A menor área queimada nas zonas agrícolas foi a interface urbano-agrícola e a interface de cultivos con especies caducifolias, un feito ben comprobado en numerosos países do noso contorno (Nunes et al. 2005, Bajocco e Ricotta 2008, Moreira et al. 2009 e 2011, Carmo et al. 2011, Oliveira et al. 2014) e tamén en Galicia (Calviño-Cancela 2014, 2016 e 2017, Picos et al. 2019). Iso é debido principalmente á conxunción de menor carga e conectividade de combustibles existentes, menor inflamabilidade e maior humidade nas zonas onde esa vexetación medra. Tamén pola maior rapidez e facilidade de intervención e concentración dos recursos de extinción nelas.

Aínda que as tendencias do cambio global non parecen favorecer un retorno da poboación ao rural e a reactivación dos usos tradicionais, unha reordenación e diversificación deses usos da terra, incluíndo pastoreo controlado, cultivos agrícolas e aproveitamento de recursos diversos, podería ser de grande axuda. 
Trataríase de apoiar e desenvolver unha bioeconomía forestal (European Forest Institute 2019) e manter e expandir as actuais devasas formadas arredor dos núcleos habitados (as chamadas faixas secundarias de xestión de biomasa) coa inclusión de cultivos e pasto (Moreira et al. 2009, Moreira e Pe'er 2018, Pais et al. 2019) que axudasen á súa rendibilidade. Non obstante, non se pode esquecer que a interface agrícola-forestal adoita ser unha zona de alta frecuencia de incendios en toda Europa (Ganteuame et al. 2013), na Península Ibérica (Catry et al. 2009, Martínez et al. 2009, Martínez-Fernández et al. 2013, Ortega et al. 2012) e tamén en Galicia (Chas-Amil et al. 2010, 2013 e 2020, Barreal e Loureiro 2013, Barreal et al. 2012, Prestemon et al. 2012, Rodrigues e De la Riva 2014, Rodrigues et al. 2019). Polo tanto, esas actuacións teñen que vir da man doutras complementarias que desactiven conflitos previos sobre o uso da terra. Iso parece particularmente necesario en Galicia, dada a tradición de recorrer ao lume como expresión de conflitos e a persistencia dunha alta proporción de lumes de causa descoñecida que suxire a existencia de conflitos non resoltos.

É importante decatarse de que a nova situación require actuar sobre os combustibles a escala da paisaxe xa que é o escenario onde resulta esencial alterar a conectividade dos combustibles (Viedma et al. 2009, Ager et al. 2017, Alcasena et al. 2019, Martín-Martín et al. 2013, Salis et al. 2018, Sil et al. 2019, Palaiologou et al. 2020) para poder influír en incendios como os dos eventos extremos, que desenvolven tamén unha dinámica de propagación a grande escala, cunha enorme potencia e que posiblemente tenderán a incrementarse cada vez máis, probablemente involucrando de forma crecente áreas habitadas. Iso esixe accións transversais de coordinación de diferentes departamentos da Administración e priorización dos criterios de prevención de incendios nas diferentes actuacións levadas a cabo por eles.

No ámbito forestal máis estrito, o das masas arbóreas, nin toda a silvicultura pode virar arredor do problema dos incendios nin pode facerse de costas ao lume (Vega 2015). En calquera caso, tórnase imperativo polo menos un aumento substancial dos tratamentos preventivos en superficies «estratéxicas», é dicir, aquelas onde as intervencións poden servir de axuda efectiva na defensa doutras de gran valor ou potencien a capacidade de extinción do lume. Producíronse numerosas achegas sobre este tema nestes últimos anos (p. ex. Finney 2001, Schmidt et al. 2008, Wei 2012, Wei et al. 2008, Ager et al. 2010 e 2017, 
Alcasena et al. 2015, 2018 e 2019, Thompson et al. 2013 e 2016, Salis et al. 2016, Madrigal et al. 2018, Quílez et al. 2020). Iso ofrecería tamén mellores oportunidades para unha extinción máis segura e eficaz (Rodríguez e Silva et al. 2014, Thompson et al. 2016 e 2019, Picos 2018, González-Olabarría et al. 2019, Quílez et al. 2020). O gran reto é planificar e executar esas áreas e especialmente mantelas operativas nun clima como o de Galicia, de alto crecemento da vexetación. Tamén artellar unha resposta unitaria en multitude de pequenas fraccións de terra de propiedade particular (Fischer e Chandley 2012, Parlamento de Galicia 2018). A utilización da silvopascicultura (Rigueiro et al. 1999, 2002 e 2009, Mosquera et al. 2005, 2018a e 2018b), coa mestura de especies forestais e pratenses, e o uso do gando poderían ser ferramentas eficaces no control da excesiva acumulación de vexetación, tanto en zonas de arboredo como en matogueira. Tamén tratamentos como a queima prescrita (Vega et al. 1994, 2000b, 2001 e 2010b, Vega e Vélez 2000, Fernandes 2015 e 2018, Fernandes e Botelho 2003, Marino et al. 2012, Fernandes et al. 2013) e trituración ou roza selectiva poderían combinarse cos anteriores coa mesma finalidade (Fernández Filgueira et al. 2012, 2013a, 2013b, 2013c, 2013d e 2015, Fontúrbel et al. 2017b, Lasanta et al. 2018, Ruiz-Mirazo et al. 2011). Así mesmo, a extracción de biomasa con fins enerxéticos (Madrigal et al. 2017), alén da mestura das masas forestais con cultivos, a agroforestería (Smith 2010, Kay et al. 2019, Daminaidis et al. 2020), os novos aproveitamentos e revaloración da economía do carbono, a mellora de biodiversidade e doutros servizos ecosistémicos e intanxibles forestais. Todo iso en liña coa nova visión da bioeconomía forestal (Wolfslehner et al. 2016, Laakonen et al. 2018, Ludwig et al. 2019, Ilaria et al. 2020).

As plantacións de eucalipto son invocadas ás veces como coadxuvadoras ao elevado número de incendios forestais en Galicia (Cordero 2017). Aínda que se necesitan máis estudos para verificar esa cuestión, Marey (2019) argumentou recentemente que o $70 \%$ das parroquias catalogadas polo Pladiga (Xunta de Galicia 2019) como de alta actividade incendiaria (polo seu alto número de incendios nos 5-7 anos precedentes e a gran superficie queimada nos 10 anos inmediatamente precedentes) non ten ningunha superficie plantada de eucalipto. Ademais, naquelas en que hai eucalipto, a superficie ocupada por este non excede o $8 \%$ da superficie da parroquia. Independentemente do anterior, nas 
200 parroquias de Galicia que teñen máis do $50 \%$ da súa superficie cuberta de eucaliptais, a media do número de incendios nos últimos 10 anos foi bastante baixa (2,59 incendios por parroquia) e no $30 \%$ delas non se produciu ningún incendio nos últimos dez anos, a pesar de que existiron todos os anos períodos de alto risco que facilitarían a ignición e propagación do lume. Tamén, unha recente investigación en Portugal, con características bioclimáticas e socioeconómicas similares a Galicia (Fernandes et al. 2019b), concluíu que non se puido demostrar que a expansión do eucalipto, ocorrida basicamente entre 1980 e 2017, fose influente no incremento da área queimada no país nese período. De feito, o tamaño de incendio durante ese período foi independente da composición das masas forestais ardidas. As variables que explicaron máis variabilidade interanual na área queimada foron, por esa orde, o perigo meteorolóxico, o número de lumes $<1$ ha, a presenza de episodios de inestabilidade atmosférica moi pronunciada e a área queimada acumulada nos seis anos anteriores.

Coma outras moitas especies forestais e de matogueira, os piñeiros e eucaliptos, principais especies dos montes repoboados galegos, son inflamables, pero o comportamento do lume pode ser moi diferente nas súas plantacións, dependendo da estrutura das masas. Esa variable ten un efecto xeralmente máis pronunciado que a especie no comportamento do lume (Fernandes, 2009, Fernandes et al. 2019, Arellano et al. 2017), exceptuando as caducifolias, cunha menor inflamabilidade, no sentido amplo do termo. Por exemplo, os poboamentos forestais xuvenís son máis propensos aos lumes de copa, independentemente da especie, dada a menor altura da copa e a maior cantidade de mato no sotobosque, asociada a esa etapa de desenvolvemento. Así, Fernández-Alonso et al. (2013 e 2016) encontraron que a densidade aparente da biomasa foliar da copa e a altura da base da copa dos piñerais galegos son importantes para avaliar a súa susceptibilidade ao lume de copa. Tamén que esa variable e a cobertura de matogueira baixo arboredo tiveron marcada influencia no nivel de severidade do lume, nun conxunto analizado de incendios en Galicia.

Mentres tanto, un factor asociado a eses dous tipos de vexetación que pode ter peso na área queimada é a continuidade das súas masas, favorecida pola extensión relativa ocupada por elas e a expansión das matogueiras, debido ao abandono da actividade agrícola e pastoral, que contribúe á conectividade do combustible a nivel de paisaxe. É, por tanto, razoable esperar que ambos os tipos 
de vexetación teñan un peso relativo na área anual queimada, como ocorre no norte e centro de Portugal, cunha vexetación similar (Fernandes et al. 2016a, Fernandes e Guiomar 2017). Por conseguinte, as intervencións de silvicultura preventiva nesas masas son moi necesarias. De calquera xeito, diversos estudos (Moreira et al. 2009 e 2011 Carmo et al. 2011) indican que as diferenzas relativas aos tipos de cubertas forestais, en termos de maior ou menor propensión a arder, son relativamente pequenas (Rego e Silva 2014), aínda que as caducifolias mostran unha menor facilidade de ignición e propagación do lume. Ademais, a influencia do tipo de cuberta vexetal forestal faise pouco relevante cando aumenta o tamaño do incendio (Barros et al. 2014, Fernandes et al. 2016a) ou cando as condicións meteorolóxicas son extremas (Turner e Romme 1994, Bessie e Johnson 1995, Fernandes et al. 2016b e 2019, Assembleia da República 2017 e 2018). Así, Picos et al. (2019) observaron nos grandes incendios de outubro de 2017 en Pontevedra que a severidade media do lume en eucaliptais, coníferas e caducifolias difería pouco, co dano á copa de eucalipto moi variable e só un $5 \%$ maior que nas especies nativas de folla caduca. Tamén Fernandes et al. (2019b) encontraron que o tipo de bosque tivo unha influencia menor sobre a severidade do lume nos megaincendios de 2017 en Portugal.

Unha conclusión práctica que pode extraerse do anterior é que o importante non é tanto a especie como a xestión do combustible que se fai. Por exemplo, as masas tratadas de plantacións de especies produtivas poden ter un nivel de perigosidade asumible, e especialmente cando eses tratamentos son complementados con outras accións preventivas a unha escala territorial adecuada. O problema é que, en moitos casos, esas plantacións nin foron nin están a ser acompañadas das necesarias actuacións silvícolas mencionadas sobre os combustibles.

Non obstante, resulta moi axeitado diversificar a cuberta arbórea dos montes de Galicia e incrementar a superficie doutras especies forestais, especialmente caducifolias, que xeralmente amosan un menor perigo de incendios, comparadas coas citadas. Xa nunha data moi temperá, Ceballos (1938) preconizou a utilización das frondosas caducifolias, soas ou mesturadas coas coníferas nas reforestacións, e unha das razóns que aducía era pola súa menor combustibilidade. Estudos posteriores evidenciaron o acertado desa recomendación xa que as caducifolias son xeralmente menos propensas ao lume, en termos de menor superficie relativa afectada (Moreira et al. 2009, Silva et. 2009, Barros e Pereira 
2014, Calviño-Cancela et al. 2016, Fernandes et al. 2016b, Chas-Amil et al. 2020), menor nivel de dano nas masas afectadas (Fernandes et al. 2010) e menor velocidade de propagación e intensidade do lume (Forestry Canada Fire Danger Group 1992, Arellano et al. 2017). Con todo, esa resposta comparativa non é invariante e, como se ten visto, precisa de importantes matizacións (Fernandes 2009, Fernandes e Guimoar 2017, Fernandes et al. 2019, Barros e Pereira 2014, Arellano et al. 2017, Picos et al. 2019). Tamén as caducifolias ofrecen unha maior resiliencia fronte ao lume pola súa facultade de rebrote (Vallejo e Alloza 1998, Vallejo et al. 2004, Pausas et al. 2004, Valdecantos et al. 2008, Hammett et al. 2017, Hart et al. 2018), aínda que a síndrome de esgotamento da capacidade rebrotadora está tamén presente, tras elevada recorrencia do lume, e pode agravarse no futuro polo cambio climático (Karavani et al. 2018, Fairman et al. 2019).

A diferenza das outras dúas estratexias clásicas de xestión preventiva do combustible forestal, a redución e o illamento (Pyne et al. 1996), a conversión do tipo de cuberta forestal foi menos aplicada ata o de agora. Ademais da prevención de incendios, motivos relativos á mellora da biodiversidade e sustentabilidade das masas forestais, estéticos, culturais, de diversificación da produción forestal, réxime hídrico etc. tamén aconsellan a diversificación da cuberta arbórea. Aínda que no pasado a expansión dos cultivos e o sistema tradicional de explotación da terra en Galicia motivaron, principalmente, a case desaparición do bosque espontáneo caducifolio, o progresivo abandono agrario e o éxodo rural trouxeron consigo recentemente un aumento espontáneo da superficie destas especies, como os dous últimos inventarios forestais nacionais e outras avaliacións reflicten. Porén, non é posible esquecer que esas especies son máis esixentes en termos de fertilidade e profundidade edáfica, e algunhas delas en requirimentos hídricos, así como moito máis lentas de crecemento que as anteriormente mencionadas. Por tanto, é lóxico esperar que a súa expansión tropezará con dificultades de instalación en moitos lugares. $\mathrm{O}$ posible cambio na distribución de precipitación e o aumento da temperatura en Galicia polo cambio climático (Sousa et al. 2015) introducen un factor engadido de incerteza respecto á virtualidade da extensión das caducifolias menos resistentes á seca. Hai que contar tamén coa limitación nos ingresos a curto prazo que estas plantacións supoñen para uns propietarios que posúen a case totalidade do terreo 
forestal galego. Se a sociedade desexa que esas especies tomen unha presenza máis importante no monte en Galicia, como sen dúbida é desexable, será necesario facer fronte a compensacións aos propietarios pola restrición temporal imposta nas súas rendas.

\section{CONCLUSIÓNS}

Segundo se pode ver, o problema dos incendios, entendido como unha disfuncionalidade entre a sociedade e o papel ecolóxico e utilitario do lume, desde todas as perspectivas, apela finalmente á responsabilidade social. Non podemos esquecer que o cambio climático e mesmo os cambios socioeconómicos teñen unha orixe humana. Os dous representan un risco pero tamén unha ocasión para mellorar. É preciso promover, respecto ao problema dos incendios, un acordo sólido, baseado nun amplo consenso político e social, cunha perspectiva máis xeral que ata agora, e estimular cambios importantes noos diferentes sectores involucrados. Tamén suscitar un forte compromiso de responsabilidade colectiva (Barreiro 2018), coas medidas consensuadas, o máis inclusivas e participativas posibles. Os últimos graves incendios de 2017 foron un aviso -nunha escala limitada- do que pode suceder nos próximos anos se non reaccionamos como sociedade. De todos nós depende aproveitar esa oportunidade, non só para mitigar os potenciais efectos non desexados dos incendios que veñen, senón tamén para aprender a convivir co lume, e enfrontar outros problemas da nosa relación co medio natural que nos afectan como sociedade e dos que o actual réxime de lume é un reflexo. 


\section{REFERENCIAS BIBLIOGRÁFICAS}

Ager, Alan A. / Nicole M. Vaillant / Mark A. Finney (2010): «A comparison of landscape fuel treatment strategies to mitigate wildlandfire risk in the urban interface and preserve old forest structure», Forest Ecology and Manage, 259, 1556-1570.

Ager, Alan A. / Nicole M. Vaillant / Andrew J. McMahan (2013): «Restoration of fire in managed forests: model to prioritize landscapes and analyze tradeoffs», Ecosphere, 4:2, 29.

Ager, Alan A. / Jeffrey D. Kuine / Alexandra P. Fischer (2015): «Coupling the biophysical and social dimensions of wildfire risk to improve wildfire mitigation planning», Risk Analysis, 35:8, 1393-1406.

Ager, Alan A. / Cody R. Evers / Michelle A. Day / Haiganoush K. Preisler / Ana M.G. Barros / Max NiELSEN-PINCUS (2017): «Network analysis of wildfire transmission and implications for risk governance», PLoS ONE, 12:3, e0172867.

Alcasena, Fermín J. / Michele Salis / Alan A. Ager / Bachisio Arca / Domingo Molina / Donatella SPANO (2015): «Assessing landscape scale wildfire exposure for highly valuedresources in a Mediterranean area", Environmental Management, 1200-1216.

Alcasena, Fermín J. / Alan A. Ager / Michele Salis / Michelle A. Day / Cristina Vega-García (2018): "Optimizing prescribed fire allocation for managing fire risk in central Catalonia», Science of the Total Environment, 621, 872-885.

Alcasena, Fermín J. / Alan A. ager / John. D. Bailey / Nicolau Pineda / Cristina Vega-García (2019): «Towards a comprehensive wildfire management strategy for Mediterranean areas: framework development and implementation in Catalonia, Spain", Journal of Environmental Management, 231, 303-320.

Alcasena-Urdíroz, Fermín / Cristina Vega-García / Alan A. Ager / Michele M. Salis / Nicholas J. NAuSlar / F. J. MENDizÁBAl / Rafael CASTEll (2019): «Metodología de evaluación del riesgo de incendios forestales y priorización de tratamientos multifuncionales en paisajes mediterráneos», Cuadernos de Investigación Geográfica, 45:2, 571-600.

ALLÓ, María / María L. LOUREIRO (2016): «Evaluating the fulfillment of the principles of collective action in practice: A case study from Galicia (NW Spain)», Forest Policy and Economics, 73, 1-9.

Álvarez, Víctor / Juan José TABOADA / María de las Nieves Lorenzo (2011): «Cambio climático en Galicia en el siglo XXI: tendencias y variabilidad en temperaturas y precipitaciones», Avances en Ciencias de la Tierra, 2, 65-85.

Álvarez, Víctor / María de las Nieves Lorenzo / Juan Taboada / Fran Santos-GonzÁlez (2012): "Tendencias y variabilidad climática para el siglo XXI en Galicia», en Concepción Rodríguez Puebla / Antonio Ceballos Barbancho / Nube González Reviriego / Enrique Morán Tejeda / Ascensión Hernández Encinas (eds.), Cambio climático: extremos e impactos, serie A, 8, Salamanca, Publicaciones de la Asociación Española de Climatología, 23-32.

Amatulli, Giuseppe / Andrea CAMia / Jesús SAN-Miguel-Ayanz (2013): «Estimating future burned areas under changing climate in the EU-Mediterranean countries», Science of the Total Environment, 450-451, 209-222.

Anderson, Wendy R. / Miguel G. Cruz / Paulo M. Fernandes / Lachie McCaW / José Antonio Vega / Ross A. Bradstock / Liam Fogarty / Jim Gould / Greg McCarthy / Jon B. Marsden-Smedley / Stuart Matthews / Greg Mattingley / H. Grant Pearce / Brian van Wilgen (2015): «A generic, empirical-based model for predicting rate of fire spread in shrublands", International Journal of Wildland Fire, 24, 443-460. 
José A. Vega, Stéfano Arellano-Pérez, Cristina Fernández, Teresa Fontúrbel e Ana Daría Ruiz

Aquilué, Núria / Marie-Josée Fortín / Christian Messier / Lluís Brotons (2020): «The Potential of Agricultural Conversion to shape forest fire regimes in Mediterranean Landscapes», Ecosystems, 23, $34-51$.

Arellano, Stéfano (2011): «Índices meteorológicos de peligro de incendios forestales en Galicia: evidencias de cambio climático y su relación con la frecuencia de fuegos y superficie afectada», proxecto de fin de carreira, Escola de Enxeñaría Forestal, Universidade de Vigo.

Arellano, Stéfano / José A. Vega / Ana D. Ruiz / Antonio Arellano / Juan G. Álvarez / Daniel J. Vega / Elena PÉrez (2017): Foto-guía de combustibles forestales de Galicia y comportamiento del fuego asociado, Santiago de Compostela, Andavira.

Assembleia da República (2017): Relatório. Análise e apuramento dos factores relativos aos incêndios que ocorreram em Pedrogão Grande, Castanheira de Pera, Ansiāo, Alvaiázere, Figueiró dos Vinhos, Arganil, Góis, Penela, Pampilhosa da Serra, Oleiros e Sertã entre 17 e 24 de junho de 2017, Comissão Técnica Independente, Portugal.

Assembleia da República (2018): Relatório. Avaliação dos incêndios ocorridos entre 14 e 16 de outubro de 2017 em Portugal Continental, Comissão Técnica Independente, Portugal.

Azevedo João C. / César Moreira / João P. CAstro / Carlos Loureiro (2011): «Agriculture abandonment, land-use change and fire hazard in Mountain Landscapes in Northeastern, Portugal», en Landscape Ecology in Forest Management and Conservation, Springer, Berlin, Heidelberg, 329-351.

Bajocco, Sofía / Carlo RicotTa (2008): «Evidence of selective burning in Sardinia (Italy): which land-cover classes do wildfires prefer?», Landscape Ecology, 23, 241-248.

BALbOA LÓPEZ, Xesús L. (1999): «El fuego en la historia de los montes gallegos: de la roza al incendio forestal», en Eduardo Araque Jiménez (coord.), Incendios históricos: Una aproximación multidisciplinar, Jaén, Universidad Internacional de Andalucía, 255-276.

Balsa-Barreiro, José / Txomin Hermosilla (2013): «Socio-geographic analysis of wildland fires causes of the 2006's wildfires in Galicia (Spain)», Foest Systems, 22, 497-509.

Barreal, Jesús / María L. Loureiro / Juan Picos (2011): «Estudio de la incidencia de los incendios en Galicia: una perspectiva socioeconómica», Revista Galega de Economía, 20, 227-246.

Barreal, Jesús / María Loureiro / Juan Picos (2012): «Estudio de la causalidad de los incendios forestales en Galicia», Economía Agraria y Recursos Naturales, 12:1, 99-114.

BARREAL, Jesús / María LOUREIRO (2013): «Análisis espacial de la ocurrencia de incendios en Galicia durante 2006», en $6^{\circ}$ Congreso Forestal Español. Montes: Servicios y desarrollo rural, Vitoria-Gasteiz, Sociedad Española de Ciencias Forestales, 6CFE01-323.

BARREAL, Jesús / María L. LOUREIRO (2015): «Modelling spatial patterns and temporal trends of wildfires in Galicia (NW Spain)», Forest Systems, 24:2, e022.

BARREAL, Jesús / Gil JANNES (2020): «Spatial and temporal wildfire decomposition as a tool for assessment and planning of an efficient forest policy in Galicia (Spain)», Forests, 11, 811.

Barreiro, Alfonso (2018): Comunicación persoal. Subdirección Xeral de Prevención e Defensa contra os Incendios Forestais, Consellería do Medio Rural, Xunta de Galicia.

Barreiro Rivas, Xosé Luís (2018): «Del compromiso social a la acción. La lucha contra los incendios forestales», en Francisco Díaz-Fierros Viqueira (coord.), Incendios forestales: reflexiones desde Galicia, A Coruña, Hércules de Ediciones, 198-210. 
Baudena, Mara / Víctor M. Santana / M. Jaime Baeza / Susana Bautista / Marteen B. Eppinga / Lia HEMERIK et al. (2020): "Increased aridity drives post-fire recovery of Mediterranean forests towards open shrublands", New Phytologist, 225, 1500-1515.

Bedía, Joaquín / Sixto Herrera / Andrea Camia / José Manuel Moreno / José Manuel GutiérreZ (2014): «Forest fire danger projections in the Mediterranean using ENSEMBLES regional climate change scenarios», Climatic Change, 122:1-2, 185-199.

Belcher, Claire M. (ed.) (2013): Fire Phenomena and the Earth System: An Interdisciplinary Guide to Fire Science, New Jersey, Wiley.

BESSIE, Wayne C. / Edward A. JoHnson (1995): «The relative importance of fuels and weather on fire behavior in subalpine forests", Ecology, 76, 747-762.

Birot, Yves (2009): Living with Wildfires: What Science Can Tell Us, Discussion Paper 15, Joensuu, European Forest Institute.

Boubeta, Miguel / María José Lombardía / Manuel Marey-Pérez / Domingo Morales (2015): «Prediction of forest fires occurrences with area-level Poisson mixed models», Journal of Environmental Management, 154, 151-158.

BOUHIER, Abel (1979): La Galice: essai géographique d'analyse et d'interprétation d'un vieux complexe agraire, La Roche-sur-Yon (Vendée), Imp. Yonnaise.

Bowman, David M. J. S. / Jennifer Balch / Paulo ArtaXo / William J. Bond / Mark A. Cochrane / Carla M. D’Antonio / Ruth DeFries / Fay H. Johnston / Jon E. Keeley / Meg A. KrawChuk / Christian A. Kull / Michelle Mack / Max A. Moritz / Stephen Pyne / Christopher I. Roos / Andrew C. SCOTT / Navjot S. Sodhi / Thomas W. Swetnam (2011): «The human dimension of fire regimes on Earth», Journal of Biogeography, 38:12, 2223-2236.

Bowman, David M. J. S. / Grant J. Williamson / John T. Abatzoglou / Crystal A. Kolden / Mark A. COCHRANE / Alistair M. S. SMITH (2017): «Human exposure and sensitivity to globally extreme wildfire events», Nature Ecology \& Evolution, 1:3, 0058.

Bowman, David M. J. S. / Crystal A. Kolden / John T. Abatzoglou / Fay H. Johnston / Guido R. VAN DeR Werf / Mike Flannigan (2020): «Vegetation fires in the Anthropocene», Nature Reviews Earth and Enviroment, 1, 500-515.

Bradshaw, Larry S. / John E. Deeming / Robert. E. Burgan / Jack D. Cohen (1984): The 1978 National Fire Danger Rating System: Technical Documentation, U.S. Forest Service, General Technical Report INT-169.

Brotons, Lluís / Núria Aquilué / Miguel de CÁceres / Mariee-Josee Fortin / Andrew Fall (2013): «How fire history, fire suppression practices and climate change affect wildfire regimes in Mediterranean landscapes», PLoS One, 8:5, e62392.

Bruña-García, Xavier / Manuel F. MareY-Pérez (2014): «Public participation: a need of forest planning», iForest, Biogeosciences and Forestry, 7:4, 216-226.

Bruña-García, Xavier / Manuel F. MareY-PéreZ (2017): «El diálogo como instrumento contra el fuego: el caso de Galicia», en $7^{\circ}$ Congreso Forestal Español: Gestión del monte: servicios ambientales y bioeconomía, Plasencia, Sociedad Española de Ciencias Forestales, 7CFE01-393.

Butsic, Van / Maggi Kelly / Max A. Moritz (2015): «Land Use and Wildfire: A review of local interactions and teleconnections", Land, 2:4, 140-156.

BYram, George M. (1959a): «Combustion of Forest Fuels», en Kenneth P. Davis (ed.), Forest Fire: Control and Use, New York, NY, McGraw-Hill, 61-89. 
José A. Vega, Stéfano Arellano-Pérez, Cristina Fernández, Teresa Fontúrbel e Ana Daría Ruiz

Byram, George M. (1959b): «Forest Fire Behaviour», en Kenneth P. Davis (ed.), Forest Fire: Control and Use, New York, NY, McGraw-Hill, 90-123.

Calkin, E. David / Jack D. Cohen / Matthew P. Thompson / Mark A. Finney (2014): «How risk management can prevent future wildfire disasters in the wildland-urban interface», Proceedings of the National Academy of Sciences of the United States of America, 111:2, 746-751.

Calkin E. David / Mark A. Finney / Matthew P. ThOMPSOn (2015): «Negative consequences of positive feedbacks in US wildfire management», Forest Ecosystems, 2:9, 1-10.

Calviño-Cancela, María / María Luisa Chas-Amil / Julia M. Touza (2014): «Assessment offire risk in relation to land cover in WUI areas», en Domingos Xavier Viegas (ed.), Advances in Forest Fire Research, Coimbra, Imprensa da Universidade de Coimbra, 657-664.

Calviño-Cancela, María / María L. Chas-Amil / Eduardo D. García-Martínez / Julia Touza (2016): "Wildfire risk associated with different vegetation types within and outside wildland-urban interfaces», Forest Ecology and Management, 372, 1-9.

Calviño-Cancela, María / María Luisa Chas-Amil / Eduardo D. García-Martínez / Julia Touza (2017): «Interacting effects of topography, vegetation, human activities and wildland-urban interfaces on wildfire ignition risk», Forest Ecology and Management, 397, 10-17.

Calvo-Iglesias, María Silva / Ramón Urbano Fra-Paleo / Ramón Alberto Díaz-Varela (2009): "Changes in farming system and population as drivers of land cover and landscape dynamics: the case of enclosed and semi-open field systems in Northern Galicia (Spain)», Landscape and Urban Planing, 90, 168-177.

Camia, Andrea / Giuseppe Amatulli / Jesús San-Miguel-Ayanz (2008): Past and future trends of forest fire danger in Europe, Luxembourg, Office for Official Publications of the European Communities.

CAmia, Andrea / Giuseppe Amatulli (2009): «Weather Factors and Fire Danger in the Mediterranean», en Emilio Chuvieco (ed.), Earth Observation of Wildland Fires in Mediterranean Ecosystems, Berlin / Heidelberg, Springer, 71-82.

Camia, Andrea / Jesús San-Miguel-Ayanz / Lara Vilar del Hoyo / Tracy Durrant Houston (2011): «Spatial and temporal patterns of large forest fires in Europe», EGU General Assembly, Vienna, Austria.

Campos, João C. / Julia Bernhardt / Núria Aquilué / Lluís Brotons / Jesús Domínguez / Ángela Lomba / Bruno Marcos / Fernando Martínez-Freiría / Francisco Moreira / Silvana Pais / João P. HONRADO / Adrián REgOS (2020): «Using fire to enhance rewilding when agricultural policies fail», Science of the Total Environment, 755:1, 14289.

Carmo, Miguel / Francisco Moreira / Pedro Casimiro / Pedro Vaz (2011): «Land use and topography influences on wildfire occurrence in northern Portugal", Landscape and Urban Planning, 100, 169-176.

Castellnou, Marc / Nuria Prat-Guitart / Etel Arilla / Asier Larrañaga / Edgar Nebot / Xavier Castellarnau / Jordi Vendrell / Josep Pallàs / Joan Herrera / Marc Monturiol / José Cespedes / Jordi Pagés / Claudi Gallardo / Marta Miralles (2019): «Empowering strategic decision-making for wildfire management: Avoiding the fear trap and creating a resilient landscape», Fire Ecology, 15:31.

CATRY, Filipe Xavier / Francisco C. REGO / Fernando C. BAÇÃO / Francisco MoreIRA (2009): «Modelling and mapping wildfire ignition risk in Portugal», International Journal of Wildland Fire, 18, 921-931.

Ceballos y Fernández de CóRdoba, Luis (1938): Regresión y óptimo de la vegetación en los montes españoles. La significación de los pinares, Ávila. 
Cela GonZÁlez, Miguel Ángel (2018): «Experiencias adquiridas de los episodios de incendios registrados en el período 2014-2017. Comunidad Autónoma de Galicia», III Taller de Lecciones Aprendidas de los Incendios Forestales, Universidad de Córdoba.

Chas-Amil, María Luisa (2007): «Forest fires in Galicia (Spain): Threats and challenges for the future», Journal of Forest Economics, 13:1, 1-5.

Chas-Amil, María Luisa / Julia Touza / Jeffrey P. Prestemon (2010): «Spatial distribution of human-caused forest fires in Galicia (NW Spain)», en Giovanni Perona / Carlos A. Brebbia (eds.), Modelling, Monitoring and Management of Forest Fires II (WIT Transactions on Ecology and the Environment), 137, 247-258.

Chas-Amil, María Luisa / Julia TouZa / Eduardo García-MarTínez (2013): «Forest fires in the wildland-urban interface: A spatial analysis of forest fragmentation and human impacts», Applied Geography, 43, 127-137.

Chas-Amil, María Luisa / Jeffrey P. Prestemon / Colin J. McClean / Julia Touza (2015): «Human-ignited wildfire patterns and responses to policy shifts», Applied Geography, 56, 164-176.

Chas-Amil, María Luisa / Eduardo García-Martínez / Julia Touza (2020): «Iberian Peninsula October 2017 wildfires: Burned area and population exposure in Galicia (NW of Spain)», International Journal of Disaster Risk Reduction, 48, 101623.

CoHen, Jack (2008): «The Wildland-Urban Interface Fire Problem», Forest History Today, Fall, 20-26.

Coldins, Ross D. / Richard de Neufville / João Claro / Tiago Oliveira / Abílio P. PaCheco (2013): «Forest fire management to avoid unintended consequences: A case study of Portugal using system dynamics», Journal of Environmental Management, 130, 1-9.

CONDE-VÁzQUEZ, Erica (2019): «Comunicación de crisis: fake news y seguimiento informativo en la ola de incendios de Galicia en octubre de 2017», Revista Española de Comunicación en Salud, suplemento 1, 107-114.

Corbelle Rico, Eduardo / Rafael Crecente Maseda (2014): «Urbanización, forestación y abandono. Cambios recientes en el paisaje de Galicia, 1985-2005», Revista Galega de Economía, 23:1, 219-228.

Cordero Rivera, Adolfo (2017): «Large scale eucalypt plantations associated to increased fire risk», PeerJ Preprints, 5, e3348v1.

Costafreda-Aumedes, Sergi / Cristina Vega-García (2014): «ANN multivariate analysis of factors that influence human-caused multiple fire starts», en Domingos Xavier Viegas (ed.), Advances in Forest Fire Research, Coimbra, Universidade, 1787-1798.

Costafreda-Aumedes, Sergi / Carles Comas / Cristina Vega-García (2016): «Spatio-temporal configurations of human-caused fires in Spain through point patterns", Forests, 7, 185.

Cruz, Miguel G. (2000): Descrição do Sistema Canadiano de Indexação do Perigo de Incêndio, Coimbra, Associação para o Desenvolvimento de Aerodinâmica Industrial.

CruZ, Raquel / Ángeles LAgo / Ana LAGe / María Ermitas Rial / Francisco DíAZ-Fierros / Santiago SALSÓN (2009): «Evolución recente do clima en Galicia: tendencias observadas en variables meteorolóxicas», en Vicente Pérez Muñuzuri / Marisa Fernández Cañamero / José Luis Gómez Gesteira (coords.), Evidencias e impactos do cambio climático en Galicia, Santiago de Compostela, Xunta de Galicia, 19-54.

Cruz Guerrero, Raquel / María de los Ángeles Lago NúÑez (2007): «Estudio de balance hídrico y viento: comparación del año 2006 con años anteriores», en Francisco Díaz-Fierros Viqueira / Xesús Balboa López / Xosé Luís Barreiro Rivas (coords.), Por unha nova cultura forestal fronte aos incendios: informes e conclusións, Santiago de Compostela, Consello da Cultura Galega, 103-136. 
José A. Vega, Stéfano Arellano-Pérez, Cristina Fernández, Teresa Fontúrbel e Ana Daría Ruiz

Damianidis, Christos / José Javier Santiago-Freijanes / Michael den Herder / Paul J. Burgess / M. Rosa Mosquera losada / Anil Graves / Andreas Papadopoulos / Andrea Pisanelli / Francesca CAmilli / Mercedes Rois-Díaz / Sonja Kay / João H. N. Palma / Anastasia Pantera (2020): «Agroforestry as a sustainable land use option to reduce wildfire risk in European Mediterranean areas", Agroforestry Systems (https://doi.org/10.1007/s10457-020-00482-w).

Delgado-Arango, Natalia / Miguel Vicente-Mariño (2019): «La cobertura periodística de los incendios forestales en la prensa digital de España: el caso de Galicia 2017», Revista Española de Comunicación en Salud, suplemento 1, 91-10.

Depietri, Yaella / Daniel E. Orenstein (2019): «Fire-regulating services and disservices with an application to the Haifa-Carmel region in Israel», Frontiers in Environmental Science, 7.

Díaz-Delgado, Ricardo / Franciso LlOret / Xavier Pons / Jaume Terradas (2002): «Satellite evidence of decreasing resilience in Mediterranean plant communities after recurrent wildfires", Ecology, 83, 2293-2303.

Díaz-Fierros Viqueira, Francisco (2018): «Historia dos incendios forestais en Galicia e Portugal», Coloquio Galaico-Portugués sobre Incendios Forestais: Unha nova xeración de lumes? Santiago de Compostela, Consello da Cultura Galega.

Diego, Jaime de / Antonio RÚa / Mercedes Fernández (2019) «Designing a Model to Display the Relation between Social Vulnerability and Anthropogenic Risk of Wildfires in Galicia, Spain», Urban Science, 3, 32 .

Dunn, Christopher J. / Christopher D. O'Connor / Jesse Abrams / Matthew P. Thompson / Dave E. CALKIn / James D. Johnston / Rick Stratton / Julie GilberTSON-Day (2020): «Wildfire risk science facilitates adaptation of fire-prone social-ecological systems to the new fire reality», Environment Research Letters, 15, 025001.

Dupuy, Jean-Luc / Helene Fargeon / Nicolas Martin-Stpaul / François Pimont / Julien Ruffault / Mercedes Gujjarro Hernando / Javier M. Madrigal / Paulo Fernandes (2020): «Climate change impact on future wildfire danger and activity in southern Europe: a review», Annals of Forest Science, 77, 35 .

EDWARDS, Amanda / Nicholas GILL (2016): «Living with landscape fire: Landholder understandings of agency, scale and control within fiery entanglements», Faculty of Social Sciences - Papers, Australia,University of Wollongong, 2644.

Elia, Mario / Raffaele Lafortezza / Giuseppe Colangelo / Giovanni Sanesi (2014): «A streamlined approach for the spatial allocation of fuel removals in wildland-urban interfaces», Landscape Ecology, 29, 1771-1784.

EsPelta, Josep María / Iraima VerKaiK / Marcia Eugenio / Francisco Lloret (2008): «Recurrent wildfires constrain long-term reproduction ability in Pinus halepensis Mill», International Journal of Wildland Fire, 17, 579-585.

European Commission (Victoriano Ramón Vallejo Calzada / Nicolas Faivre / Francisco Manuel Cardoso Castro Rego / José Manuel Moreno Rodríguez / Gavriil Xanthopoulos) (2018): Forest Fires. Sparking Firesmart Policies in the EU, Luxembourg, European Commission.

EUROPEAN FOREST INSTITUTE (2019): «Fighting catastrophic forest fires» (https://www.efi.int/articles/ fighting-catastrophic-forest-fires) [última consulta: xaneiro, 2019].

EveretT, Yvonne (2002): «Community participation in fire management planning: a cas from California», en P. Moore / David Ganz / Lay Cheng Tan / Thomas Enters / Patrick B. Durst (eds.), Community in 
flames. Proceedings of an international conference on community involvement in fire management, FAO Rap Publication 2002/25.

FAirman, Thomas A. / Laurent T. BennetT / Craig R. NiTSChKe (2019): «Short-interval wildfires increase likelihood of resprouting failure in fire tolerant trees», Journal of Environmental Management, 231, 59-65.

FAO (Food and Agriculture Organization of the United Nations) (2008): Workshop «Forest Fires in the Mediterranean Region: Prevention and Regional Cooperation», Sabaudia, Italy, 12-15 May.

FAO (Food and Agriculture Organization of the United Nations) (2011): Community-Based Fire Management: A Review, FAO Forestry Paper 166, Rome.

FAO (Food and Agriculture Organization of the United Nations) (2012): Community-Based Fire Management Meeting (FAO Rome, 12-13 November) - Report, Fire Management Working Paper 28, Rome.

FERNANDES, Paulo (2008): «Forest fires in Galicia (Spain): the outcome of unbalanced fire management», Journal of Forest Economy, 14, 155-157.

FERNANDES, Paulo M. (2009): «Combining forest structure data and fuel modelling to classify fire hazard in Portugal», Annals of Forest Science, 66, 415.

FERnANDES, Paulo M. (2013): «Fire-smart management of forest landscapes in the Mediterranean basin under global change», Landscape and Urban Planning, 110:1, 175-182.

FERnANDES, Paulo M. (2015): «Empirical Support for the Use of Prescribed Burning as a Fuel Treatment», Current Forestry Reports, 1, 118-127.

Fernandes, Paulo M. / Herminio S. Botelho (2003): «A review of prescribed burning effectiveness in fire hazard reduction", International Journal of Wildland Fire, 12:2, 117-128.

Fernandes, Paulo M. / Ana LuZ / Carlos Loureiro (2010): "Changes in wildfire severity from maritime pine woodland to contiguous forest types in the mountains of northwestern Portugal», Forest Ecology and Management, 260, 883-892.

Fernandes, Paulo M. / Davies G. M. / Davide Ascoli / Cristina Fernández / Francisco Moreira / Eric Rigolot / Cathelijne R. Stoof / José A. Vega / Domingo Molina (2013): «Prescribed burning in southern Europe: developing fire management in a dynamic landscape», Frontiers in Ecology and the Environment, 11, e4-e14.

Fernandes, Paulo M. / Carlos Loureiro / Nuno Guiomar / Gianni B. Pezzatti / Filipa T. Manso / Luís LOPES (2014): «The dynamics and drivers of fuel and fire in the Portuguese public forest», Journal of Environmental Management, 146, 373-382.

Fernandes, Paulo M. / Ana M. G. Barros / Anita Pinto / João A. Santos (2016a): "Characteristics and controls of extremely large wildfires in the western Mediterranean Basin", Journal of Geophysical Research: Biogeosciences, 121:8, 2141-2157.

Fernandes, Paulo M. / Tiago Monteiro-Henriques / Nuno Guiomar / Carlos Loureiro / Ana M. G. Barros (2016b): «Bottom-Up Variables Govern Large-Fire Size in Portugal», Ecosystems, 19:8, 1362$-1375$.

Fernandes, Paulo M. / Abilio Pereira Pacheco / Rui Lopes Almeida / João Claro (2016c): «The role of fire-suppression force in limiting the spread of extremely large forest fires in Portugal», European Journal of Forest Research, 135, 253-262.

Fernandes Paulo M. / Nuno Guiomar (2017): «Os incendios como causa de desarborização em Portugal», Agrotec, 22, 28-32. 
José A. Vega, Stéfano Arellano-Pérez, Cristina Fernández, Teresa Fontúrbel e Ana Daría Ruiz

FERnANDES, Paulo M. (2018): «Scientific support to prescribed underburning in southern Europe: What do we know?», Science of the Total Environment, 630, 340-348.

Fernandes, Paulo M. / Nuno Guiomar / Carlos G. Rossa (2019b): «Analysing eucalypt expansion in Portugal as a fire-regime modifier», Science of The Total Environment, 666, 79-88.

Fernández, Cristina / José Antonio Vega / Teresa Fontúrbel / Enrique Jiménez / Pedro Pérez-Gorostiaga (2008): «Effects of wildfire, salvage logging and slash manipulation on Pinus pinaster Ait. recruitment in Orense (NW Spain)», Forest Ecology and Management, 255, 1294-1304.

FernándeZ, Cristina / José Antonio Vega / Teresa Fontúrbel / Enrique Jiménez / Andrea Ferreiro / Benjamín SANDE (2010): «Fire severity and soil water repellency after fire in Galicia (NW Spain)», en VI International Conference on Forest Fire Research, Coimbra, Portugal.

FERnÁndez, Cristina / José Antonio Vega (2016a): «Modelling the effect of soil burn severity on soil erosion at hillslope scale in the first year following wildfire in NW Spain», Earth Surface Processes and Landforms, 41, 928-935.

FERNÁNDEZ, Cristina / José A. VEGA (2016b): «Effects of mulching and post-fire salvage logging on soil erosion and vegetative regrowth in NW Spain", Forest Ecology and Management, 375, 46-54.

FernándeZ-Couto, Tomás (2006): «Los incendios forestales en Galicia», Anales de la Real Sociedad Económica de Amigos del País de Valencia, Universidad de Valencia, 401-412.

Fernández Filgueira, Cristina / José Antonio Vega Hidalgo / Teresa Fontúrbel Lliteras (2012): «The effects of fuel reduction treatments on runoff, infiltration and erosion in two shrubland areas in the north of Spain», Journal of Environmental Management, 105, 96-102.

Fernández Filgueira, Cristina / José Antonio Vega Hidalgo / Teresa Fontúrbel Lliteras (2013a): «Shrub resprouting response after fuel reduction treatments: Comparison of prescribed burning, clearing and mastication", Journal of Environmental Management, 117C, 235-241.

Fernández Filgueira, Cristina / José Antonio Vega Hidalgo / Teresa Fontúrbel Lliteras (2013b): «Does fire severity influence shrub resprouting after spring prescribed burning?», Acta Oecologica, 48, 30-36.

Fernández Filgueira, Cristina / José Antonio Vega Hidalgo / Teresa Fontúrbel Lliteras (2013c): «Effects of fuel reduction treatments on a gorse shrubland soil seed bank in the north of Spain: Comparing mastication and prescribed burning», Ecological Engineering, 57, 79-87.

Fernández Filgueira, Cristina / José Antonio Vega Hidalgo / Teresa Fontúrbel Lliteras (2013d): «Fuel reduction at a Spanish heathland by prescribed fire and mechanical shredding: Effects on seedling emergence», Journal of Environmental Management, 129C, 621-627.

Fernández Filgueira, Cristina / José Antonio Vega Hidalgo / Teresa Fontúrbel Lliteras (2013e): «Severidad del fuego y repelencia al agua en el suelo después de incendios forestales en Galicia», en $\sigma^{\circ}$ Congreso Forestal Español. Montes: Servicios y desarrollo rural, Vitoria-Gasteiz, Sociedad Española de Ciencias Forestales, 6CFE01-351.

Fernández Filgueira, Cristina / José Antonio Vega Hidalgo / Teresa Fontúrbel Lliteras (2015): «Does shrub recovery differ after prescribed burning, clearing and mastication in a Spanish heathland?», Plant Ecology, 2016:3, 429-437.

Fernández-García, Víctor / Elena Marcos / Peter Z. Fulé / Elena Marcos / Leonor Calvo (2019): «The role of fire frequency and severity on the regenerationof Mediterranean serotinous pines under diferent environmental conditions", Forest Ecology and Management, 444, 59-68.

FINNEY, Mark A. (2020): «The wildfire system and challenges for engineering», Fire Safety, 103085. 
FINNEY, Mark A. (2001): «Design of regular landscape fuel treatment patterns for modifying fire growth and behavior", Forest Science, 47, 219-228.

Fischer, A. Paige / Susan ChARnley (2012): «Risk and cooperation Managing hazardous fuel in mixed ownership landscapes», Environmental Management, 49:6, 1192-1207.

Fischer, A. Paige / Thomas. A. Spies / Toddi A. Steelman / Cassandra Moseley / Bart. R. Johnson / J. John D. Bailey / Alan A. Ager / Patrick Bourgeron / Susan Charnley / Brandon M. Coluins / Jeffrey D. Kuine / Jessica. E. Leahy / Jeremy. S. Littell / James D. A. Millington / Max Nielsen-Pincus / Christine. S. Olsen / Travis. B. Paveglio / Christopher I. Roos / Michelle. M. Steen-Adams / Forrest. R. Stevens / Jelena Vukomanovic / Eric M. White / David M. J. S. Bowman (2016): «Wildfire risk as a socioecological pathology», Frontiers in Ecology and the Environment, 14:5, 276-284.

Fontúrbel Lliteras, María Teresa / Cristina Fernández Filgueira / José Antonio Vega hidalgo / Agustín Merino (2017a): «Cambios en el carbono orgánico y en propiedades físicas del suelo después de incendios de distinta severidad», en 70 Congreso Forestal Español: Gestión del monte: servicios ambientales y bioeconomía, Plasencia, Sociedad Española de Ciencias Forestales, 7CFE01-442.

Fontúrbel, María Teresa / Cristina Fernández Filgueira / José Antonio Vega (2017b): «Prescribed burning versus mechanical treatments as shrubland management options in NW Spain: Mid-term soil microbial response», Applied Soil Ecology, 107, 334-346.

Forestry Canada Fire Danger Group (1992): Development and structure of the Canadian forest fire behavior prediction system, Forestry Canada, Information Report ST-X-3, Ottawa, ON.

Francisco, Manuel (2019): Comunicación persoal. Servizo Provincial de Prevencion e Defensa contra os Incendios Forestais, Pontevedra, Consellería do Medio Rural, Xunta de Galicia.

Fuentes-SANTOS, Isabel / Manuel MAREY-PÉREZ / Wenceslao GonZÁLEZ-MANTEIGA (2013): «Forest fire spatial pattern analysis in Galicia (NW Spain)», Journal of Environmental Management, 128, 30-42.

Ganteaume, Anna / Andrea Camia / Marielle Jappiot / Jesús San-Miguel-Ayanz / Marlène Long-FouRnel / Corinne LAMPIN (2013): «A Review of the Main Driving Factors of Forest Fire Ignition over Europe», Environmental Management, 51:3, 651-662.

García Díez, Eulogio Luis / Luis Rivas Soriano / Fernando de Pablo Dávila / Ángel García Díez (1994): «An objective model for the daily outbreak of forest fires based on meteorological considerations», Journal of Applied Meteorology, 33:4, 519-526.

García Díez, Eulogio Luis / Luis Rivas Soriano / Fernando de Pablo Dávila / Ángel García Díez (1999): «Prediction of the daily number of forest fires», International Journal of Wildland Fire, 9:3, 207-211.

García-Oliva, Felipe / Agustín Merino / María Teresa Fontúrbel / Beatriz Omil / Cristina FernánDEZ / José Antonio VeGA (2018): «Severe wildfire hinders renewal of soil P pools by thermal mineralization of organic P in forest soil: Analysis by sequential extraction and 31P NMR spectroscopy», Geoderma, 309, 32-40.

García-Ortiz, Álvaro (2018): «Incendios forestales. El delito de incendio y la acción de la fiscalía», en Francisco Díaz-Fierros Viqueira (coord.), Incendios forestales: reflexiones desde Galicia, A Coruña, Hércules de Ediciones, 116-135.

Gill, A. M. / K. R. Christian / P. H. R. Moore / R. I. Forrester (1987): «Bushfire incidence, fire hazard and fuel reduction burning», Australian Journal of Ecology, 12:3, 299-306. 
José A. Vega, Stéfano Arellano-Pérez, Cristina Fernández, Teresa Fontúrbel e Ana Daría Ruiz

Gómez-VÁzquez, Isabel / Pedro Álvarez-Álvarez / Manuel F. Marey-Pérez (2009): «Conflicts as enhancers or barriers to the management of privately owned common land: a method to analyze the role of conflicts on a regional basis", Forest Policy and Economics, 11, 617-627.

GonZÁlez-Olabarria, José Ramón / Keith M. Reynolds / Asier LaRrañaga / Jordi GarCía-Gonzalo / Eduard Busquets / Miriam PiQué (2019): «Strategic and tactical planning to improve suppression efforts against large forest fires in the Catalonia región of Spain", Forest Ecology and Management, 432, 612-622.

Guijarro, Mercedes / Javier Madrigal / Carmen Hernando / David Sánchez de Ron / Antonio VázQUEZ DE LA Cueva (2018): «Las repoblaciones y los incendios forestales", en Jesús Pemán García / Ignacio Iriarte Goñi / Francisco Lario Leza, (coords.), La restauración forestal de España: 75 años de una ilusión, [Madrid], MAPAMA, SECF, 344-376.

GUITIÁN RIVERA, Luis (1999): «Los incendios forestales a través de la historia: pervivencias y cambios en el uso del fuego en en el noroeste peninsular», en Eduardo Araque Jiménez (coord.), Incendios históricos: una aproximación multidisciplinar, Jaén, Universidad Internacional de Andalucía, 149-162.

Hamilton, Matthew / Alexandra Paige Fischer / Seth D. Guikema / Gretchen Keppel-Aleks (2018): «Behavioral adaptation to climate change in wildfire-prone forests», Wiley Interdisciplinary Reviews: Climate Change, 9:6, e553.

Hamilton, Matthew / Alexandra Paige Fischer / Alan Ager (2019): «A social-ecological network approach for understanding wildfire risk governance», Global Environmental Change, 54, 113-123.

Hammett, Ethan J. / Martin W. Ritchie / John PAsCAl Berrill (2017): «Resilience of California black oak experiencing frequent fire: regeneration following two large wildfires 12years apart», Fire Ecology, 13:1, 91-102.

He, Tianhua / Bryon B. LAmont / Juli G. PAusas (2019): «Fire as a key driver of Earth's biodiversity», Biological Reviews, 94, 1983-2010.

Hernando, Carmen / Rosa Planelles GonzÁlez / Marta Ortega / Santigo Garrido / Javier Madrigal Olmo / Mercedes Guijarro / Jose Ignacio Aragonés / Ana Sebastián (2012): «La opinión de los gestores e investigadores sobre la prevención de incendios forestales en España: resultados del cuestionario "FIRESMART"”, Montes, 109, 33-38.

Hirsch, Kevin / Victor KafKa / Cordy Tymstra / Rob McAlpine / Brad HawKes / Herman Stegehuis / Sherra Quintilios / Sylvie GaUTHIER / Karl PeCK (2001): «Fire-smart forest management: A pragmatic approach to sustainable forest management in fire-dominated ecosystems», The Forestry Chronicle, 77, $1-7$.

HowITT Richard (2014): "Coexisting with Fire? A Commentary on the Scale Politics of Adaptation", Geographical Research, 52:1, 61-64.

INGALSBEE, Timothy (2017): «Whither the paradigm shift? Large wildland fires and the wildfire paradox offer opportunities for a new paradigm of ecologicalfire management», International Journal of Wildland Fire, 26:7, 557-561.

Intergovernmental Panel on Climate Change (2000): Emissions Scenarios: A Special Report of Working Group III of the Intergovernmental Panel on Climate Change. [Nebojsa N. Nakicenovic e Robert Swart (eds.)]. New York, Cambridge Univ. Press.

Intergovernmental Panel on Climate Change (2014): Climate Change 2014: Synthesis Report. Contribution of Working Groups I, II and III to the Fifth Assessment Report of the Intergovernmental Panel on Climate Change». [Core Writing Team, Rajendra K. Pachauri e Leo A. Meyer (eds.)]. Geneva, Switzerland. 
JentsCh, AnkeJentsch / Carl BeIERKUHNLEIN (2008): «Research frontiers in climate change: effects of extreme meteorological events on ecosystems», Comptes Rendus Geoscience, 340, 621-628.

Jianguo Liu / Thomas Dietz / Stephen R. Carpenter / Marina Alberti / Carl Folke / Emilio Morán / Alice N. Pell / Peter Deadman / Timothy Kratz / Jane Lubchenco / Elinor Ostrom / Z. OuYang / William Provencher / Charles Redman / Stephen H. Schneider / William W. Taylor (2007): "Complexity of coupled human and naturalsystems», Science, 317:5844, 1513-1516.

Jiménez-Ruano, Adrián / Marcos Rodrigues Mimbrero / Juan De la Riva (2017): «Understanding wildfires in mainland Spain. A comprehensive analysis of fire regime features in a climate-human context», Applied Geography, 89, 100-111.

Jiménez-Ruano, Adrián / Juan de la Riva Fernández / Marcos Rodrigues (2020): «Fire regime dynamics in mainland Spain. Part 2: A near-future prospective», Science of The Total Environment, 705, 135842 .

Jolly, W. Matthews / Mark A. Cochrane / Patrik H. Freeborn / Zachary A. Holden / Timothy J. BRown / Grant. J. Williamson / David M. Bowman (2015): "Climate induced variations in global wildfire danger from 1979 to 2013», Nature Communications, 6, 7537.

KaAl, Joeri / Antonio MarTínez Cortizas / Eileen ACKMEIER / Manuela Costa Casais / Manuel Santos Estévez / Felipe CRIADO BOAdo (2008): «Holocene fire history of black colluvial soils revealed by pyrolysis-GC/MS: a case study from Campo Lameiro (NW Spain)", Journal of Archaeological Science, $35: 8,2133-2143$.

Karavani, Asaf / Matthias M. Boer / Mara Baudena / Carlos Colinas / Rubén Díaz-Sierra / Jesús Pemán / Martín de Luis / Álvaro EnríQueZ-De-Salamanca / Víctor Resco DE Dios (2018): «Fire-induced deforestation in drought-prone Mediterranean forests: drivers and unknowns from leaves to communities», Ecological Monographs, 88, 141-169.

Kay, Sonja / Anil Graves / João H. N. Palma / Gerardo Moreno / José V. Roces-Díaz / Stephanie Aviron / Dimitrios Chouvardas / Josep Crous-Duran / Nuria Ferreiro-Domínguez / Silvestre García de Jalón / Vlad Macicasan / M. Rosa Mosquera / Anastasia Pantera / José Javier SantiaGo-Freijanes / Erich Szerencsits / Mario Torralba / Paul J. Burgess / Felix Herzog (2019): «Agroforestry is paying - Economic evaluation of ecosystemoservices in European landscapes with and without agroforestry systems», Ecosystem Services, 36, 100896.

KLINKE, Andreas / Ortwin RENN (2002): «A new approach to risk evaluation and management: risk-based, precaution-based, and discourse-based strategies», Risk Analysis, 22:6, 1071-1094.

Krebs, Patrik / Gianni Boris Pezzatti / Stefano Mazzoleni / Lee M. TAlbot / Marco Conedera (2010): "Fire regime: history and definition of a key concept in disturbance ecology», Theory in Biosciences, 129:1, 53-69.

LaAKKonen, Anu / Teppo Hujala / Jouni PYKäLÄINEN (2018): «Integrating intangible resources enables creating new types of forest services-developing forest leasing value network in Finland", Forest Policy Economy, 99, 157-168.

Lasanta, Tedoro / Makki Khorchania / Fenando Pérez-Cabello / Pilar Errea / Raquel Sáenz-Blanco / Estela NADAL-ROMERO (2018): «Clearing shrubland and extensive livestock farming: Active prevention to control wildfires in the Mediterranean mountains», Journal of Environmental Management, 227, 256-266.

LiU, Jianguo / Thomas Dietz / Stephen R. CARPEnter / Marina Alberti / Carl FolKe / Emilio Morán / Alice N. Pell / Peter Deadman / Timothy Kratz / Jane Lubchenc / Elinor Ostrom / Zhiyun 
Ouyang / William Provencher / Carl L. Redman / Stephen H. Schneider / William W. Taylor (2007): «Complexity of coupled human and natural systems», Science, 317:5844, 1513-1516.

LLORET Francisco / Juli G. PAUSAS / Montserrat ViLÀ (2003): «Response of Mediterranean plant species to different fire regimes in Garraf Natural Park (Catalonia, Spain): field observations and modelling predictions", Plant Ecology, 167, 223-235.

Loepfe, Lasse / Jordi Martínez-Vilalta / Jordi Oliveres / Josep Piñol / Francisco Lloret (2010): «Feedbacks between fuel reduction and landscape homogenization determine fire regimes in three Mediterranean areas", Forest Ecology and Management, 259:12, 2366-2374.

LÓPEZ IgLESIAS, Edelmiro (2018): «Desestructuración del medio rural, usos del suelo y gestión del territorio. El contexto de fondo del problema de los incendios en Galicia», en Francisco Díaz-Fierros Viqueira (coord.), Incendios forestales: reflexiones desde Galicia, A Coruña, Hércules de Ediciones, 26-46.

López Iglesias, Edelmiro / Mar Pérez Fra (2004): "Axuste agrario e despoboamento rural», Grial, 162:XLII, 36-43.

Ludvig, Alice / Ivana Zivojinovic / Teppo Hujala (2019): «Social innovation as a prospect for the forest economy: selected examples from Europe», Forests, 10, 878.

Madrigal, Javier / Irma Fernández-Migueláñez / Carmen Hernando / Mercedes Guijarro / Daniel José Vega-Nieva / Eduardo Tolosana (2017): «Does forest biomass harvesting for energy reduce fire hazard in Mediterranean basin? A case study in Coroig Massif (Eastern Spain)», European Journal of Forest Research, 136:1, 13-26.

Madrigal, Javier / Mario Romero-Vivó / Francisco RodríGueZ y Silva (eds.) (2019): Definición y recomendaciones técnicas en el diseño de puntos estratégicos de gestión, Sociedad Española de Ciencias Forestales I Generalitat Valenciana.

Manta, María Isabel / Domingos Xavier VIEGAS (2006): «Efficiency of Two Wildfire Meteorological Risk Indexes in Three Climatic Zones of Spain», en Domingos Xavier Viegas (ed.), Proceedings of the V International Conference on Forest Fire Research, Coimbra, Universidade de Coimbra (DOI: 10.1016/j. foreco.2006.08.086).

MAPAMA (Ministerio de Agricultura, Pesca y Alimentación) (s. d.): «Estadísticas de Incendios Forestales», periodo (1968-2015) (https://www.mapa.gob.es/en/desarrollo-rural/estadisticas/Incendios_default. aspx).

Marey Pérez, Manuel F. (2019): «O eucalipto: problema ou oportunidade», Recursos Rurais, 15, 35-42.

Marey-Pérez, Manuel F. / Verónica RodrígueZ-Vicente (2008): «Forest transitions in Northern Spain: Local responses on large-scale programmes of field-afforestation», Land Use Policy, 26:1, 139-156.

Marey-Pérez, Manuel Francisco / Emilio Rafael Díaz-Varela / Alexia CAlvo-GonZÁlez (2015): «Does higher owner participation increase conflicts over common land? An analysis of communal forests in Galicia (Spain)», iForest, 8, 533-543.

Marino, Eva / Carmen Hernando / Rosa Planelles / Javier Madrigal / Mercedes Guijarro / Ana SEBASTIÁN (2014): «Forest fuel management for wildfire prevention in Spain: a quantitative SWOTanalysis», International Journal of Wildland Fire, 23:3, 373-384.

Marino, Eva / Marta Yebra / Mariluz Guillén-Climent / Nuur Algeet / José Luis Tomé / Javier Madrigal / Mercedes Guijarro / Carmen Hernando (2020): «Investigating live fuel moisture content estimation in fire-prone shrubland from remote sensing using empirical modelling and RTM Simulations", Remote Sensing, 12, 2251. 
Martín-Martín, Carmen / Robert G. H. Bunce / Santiago Saura / Elena Rosselló (2013): «Changes and interactions between forest landscape connectivity and burnt area in Spain», Ecological Indicators, 33, 129-138.

MartíneZ, Jesús / Cristina Vega-García / Emilio Chuvieco (2009): «Human-caused wildfire risk rating for prevention planning in Spain", Journal of Environmental Management, 90:2, 1241-1252.

Martínez-Fernández, Jesús / Emilio Chuvieco / Nikos Koutsias (2013): «Modelling long-term fire occurrence factors in Spain by accounting for local variations with geographically weighted regression», Natural Hazards and Earth System Sciences, 13, 311-327.

Martínez de la Torre, Alberto / Gonzalo Míguez Macho (2009): «Modelización dun escenario de futuro cambio climático en Galicia», en Vicente Pérez Muñuzuri / Marisa Fernández Cañamero / José Luis Gómez Gesteira (coords.), Evidencias e impactos do cambio climático en Galicia, Santiago de Compostela, Xunta de Galicia, 543-570.

MatHer, Alexander S. (1992): «The forest transition», Area, 24, 367-379.

Mather, Alexander S. / C. L. NeEdle (1998): «The fores, transition: a theoretical basis», Area, 30, 117-124.

MATTHEWS, Stuart (2014): «Dead fuel moisture research: 1991-2012», International Journal of Wildland Fire, 23, 78-92.

MCARTHUR, Alan Grant (1962): Control Burning in Eucalypt Forests, Leaflet 80, Canberra, Commonwealth of Australia, Department of National Development, Forestry and Timber Bureau.

MCArthur, Alan Grant (1966): Weather and Grassland Fire Behaviour, Leaflet 100, Canberra, Commonwealth of Australia, Department of National Development, Forestry and Timber Bureau.

MCARTHUR, Alan Grant (1967): Fire Behaviour in Eucalypt Forests, Leaflet 107, Canberra, Commonwealth of Australia, Department of National Development, Forestry and Timber Bureau.

McCAFfrey, Sarah / Eric Toman / Melanie STIDHAm / Bruce SHINDler (2013): «Social science research related to wildfire management: an overview of recent findings and future research needs», International Journal of Wildland Fire, 22:1, 15-24.

Mclaughlan, Kendra K. / Phillip E. Higuera / Jessica Miesel / Brendan M. Rogers / Jennifer SCHWEITZER / Jaquelin SHUMAN et al. (2020): «Fire as a fundamental ecological process: Research advances and frontiers», Journal of Ecology, 108:5, 2047-2069.

Merino, Agustín / María T. Fontúrbel / Cristina Fernández / Bruno Chávez-Vergara / Felipe GarCíA-Oliva / José A. VEGA (2018): «Inferring changes in soil organic matter in post-wildfire soil burn severity levels in a temperate climate», Science of the Total Environment, 627, 622-632.

Milne, Mary / Helen Clayton / Stephen Dovers / Geoffrey J. Cary (2014): «Evaluating benefits and costs of wildland fires: critical review and future applications», Environmental Hazards, 13, 114-132.

Ministerio de Agricultura, Pesca y Alimentacion (2019): «Orientaciones estratégicas para la gestión de incendios forestales en España», Comité de Lucha Contra Incendios Forestales.

Moreira, Francisco / Francisco Rego / Paulo G. Ferreira (2001): «Temporal (1958-1995) pattern of change in a cultural landscape of northwestern Portugal: implications for fire occurrence», Landscape Ecology, 16:6, 557-567.

MoreIra, Francisco / Pedro Vaz / Filippe Catry / Joaquim Sande SiLVA (2009): «Regional variations in wildfire susceptibility of land-cover types in Portugal: implications for landscape management to minimize fire hazard», International Journal of Wildland Fire, 18:5, 563-574.

Moreira, Francisco / Olga Viedma / Margarita Arianoutsou / Thomas Curt / Nikos Koutsias / Eric Rigolot / Anna Barbati / Piermaria Corona / Pedro Vaz / Gavriil Xanthopoulos / Florent MouI- 
José A. Vega, Stéfano Arellano-Pérez, Cristina Fernández, Teresa Fontúrbel e Ana Daría Ruiz

LLOT / Ertugrul BiLgiLI (2011): «Landscape-wildfire interactions in southern Europe: implications for landscape management», Journal of Environmental Management, 92:10, 2389-2402.

Moreira, Francisco / Guy PE’ER (2018): «Agricultural policy can reduce wildfires», Science, 359:6379, 1001.

Moreira, Francisco / Davide Ascoli / Hugh SAFFord / Mark A. AdAMs / José Manuel Moreno / José Miguel C. Pereira / Filipe X. CATry / Juan Armesto / William Bond / Mauro E. GonZÁlez / Thomas Curt / Nikos Koutsias / Lachie McCaw / Owen Price / Juli Pausas / Eric Rigolot / Scott Stephens / Kagatay Tavsanoglu / V. Ramón Vallejo / Brian W. van Wilgen / Gavriil Xanthopoul / Paulo FERNANDES (2019): «Wildfire management in Mediterranean-type regions: paradigm change needed», Environmental Research Letters, 15:1, 011001.

Moreno, José M. / Gonzalo Zavala / María Martín / Amparo Millán (2010): «Forest fire risk in Spain under future climate change», en Josef Settele / Lyubomir D. Penev / Teodor A. Georgiev / Ralf Grabaum / Vesna Grobelnik / Volker Hammen / Stefan Klotz / Mladen Kotarac / Ingolf Kühn (eds.), Atlas of Biodiversity Risk, Sofia, Pensoft, 72-73.

Moreno, M. Vanesa / Emilio Chuvieco (2013): «Characterising fire regimes in Spain from fire statistics», International Journal of Wildland Fire, 22:3, 296-305.

Moreno, M. Vanesa / Emilio Chuvieco (2016): «Fire regime characteristics along environmental gradients in Spain", Forests, 7:11, 262.

Morgan, Penelope / Colin C. Hardy / Thomas Swetnam; Matthew G. Rollins / Donald G. Long (1999): «Mapping fire regimes across time and space: Understanding coarse and fine-scale fire patterns», International Journal of Wildland Fire, 10:3, 329-342.

Moriondo, Marco / Peter Good / Rita DurĀo / Marco Bindi / Christos Giannakopoulos / João CORTE-REAl (2006): «Potential impact of climate change on fire risk in the Mediterranean area», Climate Research, 31:1, 85-95.

Moritz, Max A. / Enric Batllori / Ross A. Bradstock / A. Malcom Gill / John Handmer / Pul F. Hessburg / Justin Leonard / Sarah McCaffrey / Dennis C. Odion / Tania Schoennagel / Alexandra D, SHYPPARD (2014): «Learning to coexist with wildfire», Nature, 515, 58-66.

Mosquera-Losada M. Rosa / José Javier Santiago-Freijanes / Andrea Pisanelli / Mercedes Rois / Jo Smith / Michael den Herder / Gerardo Moreno / Nuria Ferreiro-Domínguez / Nina Malignier / Norbert Lamersdorf / Fabien Balaguer / Anastasia Pantera / Antonio Rigueiro-Rodríguez / José A. Aldrey / Pilar GonzÁlez-Hernández / J. L. Fernández-Lorenzo / Rosa Romero-Franco / Paul J. BuRgess (2018a): «Agroforestry in the European Common Agricultural Policy», Agroforestry Systems, 92, 1117-1127.

Mosquera-Losada M. Rosa / José Javier Santiago-Freijanes / Mercedes Rois-Díaz / Gerardo Moreno / Michael den Herder / José A. Aldrey / Nuria Ferreiro-Domínguez / Anastasia Pantera / Andrea PisAnelli / Antonio Rigueiro-Rodríguez (2018b): «Agroforestry in Europe: a land management policy tool to combat climate change», Land Use Policy, 78, 603-613.

Mosquera-Losada, M. Rosa / Jim McAdam / Antonio Rigueiro-Rodríguez (eds.) (2005): Silvopastoralism and Sustainable Land Management, Wallingford, CABI Publishing.

MYERS, Ronald L. (2006): Living with Fire: Sustaining Ecosystems and Livelihoods through Integrated Fire Management, Arlington, VA, The Nature Conservancy, Global Fire Initiative.

Nelson, Ralph M. Jr. (1993): «Byram’s derivation of the energy criterion for forest and wildland fires», International Journal of Wildland Fire, 3, 131-138. 
NelSON, Ralph M. Jr. (2001): «Water Relations of Forest Fuels», en Edward A. Johnson Forest (ed.), Fires Behavior and Ecological Effects, Academic Press, 79-149.

North, Malcom P. / Scott L. Stephens / Brandom M. Collins / James K. Agee / Gregory Aplet / Jerry F. Franklin / Peter Z. Fulé (2015): «Reform forest management to work with fire», Science, 18, 1280-1281.

Nunes, María C. S. / María José Vasconcelos / José Miguel C. Pereira / Nairanjana Dasgupta / Richard J. Alldredg / Francisco C. Rego (2005): «Land cover type and fire in Portugal: do fires burn land cover selectively?», Landscape Ecology, 20, 661-673.

Oliveira, Sandra / Francisco Moreira / Ramón Boca / Jesús San-Miguel-Ayanz / José Miguel C. PEREIRA (2014): «Assessment of fire selectivity in relation to land cover and topography: a comparison between Southern European countries», International Journal of Wildland Fire, 23, 620-630.

Ortega, Marta / Santiago SAura / Sergio GonZÁlez-Ávila / Valentín Gómez / Ramón ElENA-Rosselló (2012): «Landscape vulnerability to wildfires at the forest-agriculture interface: half-century patterns in Spain assessed though the SISPARES monitoring framework», Agroforestry Systems, 85, 331-349.

Pais, Silvana / Núria Aquilué / João CAmpos / Ângelo Sil / Bruno Marcos / Fernando Martínez-Freiría / Jesús Domínguez / Lluís Brotons / João P. Honrado / Adrián Regos (2020): «Mountain farmland protection and fire-smart management jointly reduce fire hazard and enhance biodiversity and carbon seques-tration", Ecosystem Services, 44, 101143.

Palaiologou, Palaiologos / Kostas KalaboKidis / Alan A. Ager / Michelle A. Day (2020): «Development of comprehensive fuel management strategies for reducing wildfire risk in Greece», Forests, 11, 789.

Paletto, Alessandro / Ilaria Biancolillo / Jacques Bersier / Michael Keller / Manuela Romagnoli (2020): «A literature review on forest bioeconomy with a bibliometric network analysis», Journal of Forest Science, 66, 265-279.

Pardellas Santiago, Miguel / Maria Conceição Colaço / Francisco Castro Rego / Pablo Ángel Meira CARTEA (2018): «El reto educativo de los incendios forestales. De la percepción social del riesgo a la acción comunitaria», en Francisco Díaz-Fierros Viqueira (coord.), Incendios forestales: reflexiones desde Galicia, A Coruña, Hércules de Ediciones, 176-196.

Parlamento de Galicia (2018): «Reunión da Comisión especial de estudo e análise das reformas da política forestal, de prevención e extinción de incendios forestais e Plan forestal de Galicia, avaliando a experiencia acumulada dende 2006 e, especificamente, a extraordinaria vaga de lumes que vén de sufrir Galicia en outubro de 2017», Santiago de Compostela.

Paton, Douglas / Petra T. Buergelt / Fantina Tedim / Sarah McCaffrey (2015): «Wildfires: international perspectives on their socio-ecological implications», en D. Paton / P. T. Buergelt / S. M. McCaffrey / F. Tedim (eds.), Wildfire Hazards, Risks, and Disasters, Oxford, Elsevier, 1-14.

PAUSAS, Juli G. (1999): «The response of plant functional types to changes in fire regime in Mediterranean ecosystems. A simulation approach», Journal of Vegetation Science, 10, 717-722.

Pausas, Juli G. / Carmen Bladé / Alejandro Valdecantos / José P. Seva / David Fuentes / José A. Alloza / Alberto Vilagrosa / Suasana Bautista / Jordi Cortina / Ramón Vallejo (2004): «Pines and oaks in the restoration of Mediterranean landscapes of Spain: new perspectives for an old practice - a review», Plant Ecology, 171, 209-220.

Pausas, Juli G. / Jon E. KeEley (2009): «A burning story: the role of fire in the history of life», BioScience, 59, 593-601. 
José A. Vega, Stéfano Arellano-Pérez, Cristina Fernández, Teresa Fontúrbel e Ana Daría Ruiz

Pausas, Juli G. / Jon E. Keeley (2019a): «Wildfires as an ecosystem service», Frontiers in Ecology and the Environment, 17, 289-295.

Pausas, Juli G. / Jon E. Keeley (2019b): «Wildfires misunderstood», Frontiers in Ecology and the Environment, 17, 430-431.

PAUSAS, Juli G. / William J. BOND (2020). «Alternative biome states in terrestrial ecosystems», Trends in Plant Science, 25:3, 250-263.

Pazos Lamoso, Manuel Ángel / Xosé Manuel Palmeiro Ramos / Diego Conde Gómez (2018): «Del minifundio al megaincendio. Transiciones, rupturas y nuevos retos cara a un desarrollo sostenible en el medio rural gallego", Sémata: Ciencias Sociais e Humanidades, 30, 339-357.

Pereira, Mário G. / Ricardo M. Trigo / Carlos da Cámara / José M. C. Pereira / Solange M. Leite (2005): «Synoptic patterns associated with large summer forest fires in Portugal», Agricultural and Forest Meteorology, 129, 11-25.

Pérez Pereiro, Marta / Maria Ángeles Chaparro Domínguez / Jesús Díaz del Campo Lozano (2018). «La cobertura periodística de los incendios de Galicia y Portugal de octubre de 2017: Un análisis de la información de emergencia de diarios portugueses, españoles y gallegos», Estudos em Comunicação, 1:26, 197-213.

Picos, Juan / Laura Alonso / Guillermo BASTOS / Julia ARmeSto (2019) «Event-based integrated assessment of environmental variables and wildfire severity through Sentinel-2 Data», Forests, 10, 1021.

PICOS, Juan (coord.) (2018): Xera: La Cadena Forestal - Madera en Galicia 2017, Axencia Galega da Industria Forestal, Consellería de Economía e Industria, Xunta de Galicia / Universidade de Vigo.

Picos Martín, Juan (2018): «Selvicultura preventiva», en Francisco Díaz-Fierros Viqueira (coord.), Incendios forestales: reflexiones desde Galicia, A Coruña, Hércules de Ediciones, 92-115.

PIÑol, Josep / Marc CASTELLNOU / Keith BEVEN (2007): «Conditioning uncertainty in ecological models: Assessing the impact of fire management strategies», Ecological Modelling, 207, 34-44.

Planton, Serge / Michel DéQué / Fabrice Chauvin / Laurent Terray (2008): «Expected impacts of climate change on extreme climate events», Geoscience, 340, 564-574.

PODUR Justin / Mike WotTON (2010): «Will climate change overwhelm fire management capacity?», Ecological Modelling, 221, 1301-1309.

Ponte, Emmanuel da / Sergi Costafreda-Aumedes / Cristina Vega-García (2019): «Lessons learned from arson wildfire incidence in reforestations and natural stands in Spain», Forests, 10:3, 229.

Prestemon, Jeffrey P. / María Luisa ChAs-Amil / Julia TouZA / Scott L. GoodricK (2012): «Forecasting intentional wildfires using temporal and spatio-temporal autocorrelations», International Journal of Wildland Fire, 21, 743-754.

PrIOR, Tim / Christine ERIKSEN (2013): «Wildfire preparedness, community cohesion and social-ecological systems", Global Environmental Change, 23, 1575-1586.

Pyne, Stephen J. (2000): Vestal Fire: An Environmental History, Told through Fire, of Europe and Europe's Encounter with the World, Seattle, WA, University of Washington Press.

PyNe, Stephen J. (2007): «Problems, paradoxes, paradigms: triangulating fire research», International Journal of Wildland Fire, 16:3, 271-276.

PYNE, Stephen J. (2015): «The New Approach to Fighting Wildfires» (https://slate.com/technology/2015/07/box-and-burn-the-new-approach-to-fighting-wildfires.html).

Pyne, Stephen J. (2020): «Our Burning Planet: Why We Must Learn to Live With Fire» (https://e360. yale.edu/features/our-burning-planet-why-we-must-learn-to-live-with-fire). 
Pyne, Stephen J. / Patricia L. Andrews / Richard D. LAVEN (1996): Introduction to wildland fire, segunda edición, New York, John Wiley \& Sons.

Quílez, Raúl / LuZ Valbuena / Jordi Vendrell / Kathleen UyTEWAal / Joaquín RamireZ (2020): «Establishing propagation nodes as a basis for preventing large wildfires: the proposed methodology», Frontiers in Forest and Global Change, 3, 548799.

Rego, Francisco C. / Joaquim Sande Silva (2014): «Wildfires and landscape dynamics in Portugal: a regional assessment and global implications», en J. C. Azevedo et al. (eds.), Forest Landscapes and Global Change: Challenges for Research and Management, Springer, 51-73.

Regos, Adrián / Jesús Domínguez / Asunción Gil-Tena / Lluís Brotons / Miquel NinYerola / Xavier PONS (2014): «Rural abandoned landscapes and bird assemblages: winners and losers in the rewilding of a marginal mountain area (NW Spain)», Regional Environmental Change, 16, 199-211.

Regos, Adrián / Miquel Ninyerola / Gerard Moré / Xavier Pons (2015): «Linking land cover dynamics with driving forces in mountain landscape of the Northwestern Iberian Peninsula», International Journal of Applied Earth Observation and Geoinformation, 38, 1-14.

Renn, Ortwin (2008): Risk Governance: Coping with Uncertainty in a Complex World, London, Earthscan.

RESCO DE Dios, Víctor (2020): «Environmental Plant Responses and Wildland Fire Danger», en Víctor Resco de Dios, Plant-Fire Interactions. Managing Forest Ecosystems, Springer, 75-92.

Rico Boquete, Eduardo (1994): Política forestal e repoboacións en Galicia, 1941-1971, Santiago de Compostela, Universidade.

Rico BoQUeTE, Eduardo (2000): «Política forestal y conflictividad social en el Noroeste de España durante el primer franquismo, 1939-1959», Historia Social, 38, 117-140.

Rico BoqueTE, Eduardo (2018): «Los incendios y la repoblación forestal pública en Galicia, 1909-1975», en Francisco Díaz-Fierros Viqueira (coord.), Incendios forestales: reflexiones desde Galicia, A Coruña, Hércules de Ediciones, 48-67.

Rigueiro, Antonio / M. Rosa Mosquera / M. Luisa López / J. C. Pastor / M. Pilar GonzÁlez HerNÁNDEZ / R. Romero / Juan José VilLARINO URTIA (2002): «Reducción del riesgo de incendios forestales mediante el pastoreo del caballo gallego de monte», Cuadernos de la Sociedad Española de Ciencias Forestales, 14, 115-117.

Rigueiro-Rodríguez, Antonio / M. Rosa Mosquera-Losada / M. Luisa López (1999): «Silvopastoral systems in prevention of forest fires in the forests of Galicia (NW Spain)", Agroforestry Forum, 9:3, 3-8.

Rigueiro-Rodríguez, Antonio / Jim McAdam / M. Rosa MosQuera-Losada (eds.) (2009): Agroforestry in Europe: current status and future prospects, Dordrecht, Springer.

Ríos-Pena, Laura / Thomas Kneib / Carmen Cadarso-Suárez / Manuel Marey-Pérez (2017): «Predicting the occurrence of wildfires with binary structured additive regression models», Journal of Environmental Management, 187, 154-165.

Rodrigo, Anselm / Javier Retana / F. Xavier PICÓ (2004): «Direct regeneration is not the only response of Mediterranean forests to large fires», Ecology, 85, 716-729.

Rodrigues, Marcos / Juan DE LA RIVA (2014): «An insight into machine-learning algorithms to model human-caused wildfire occurrence», Environmental Modelling and Software, 57, 192-201.

Rodrigues, Marcos / Adrián JimÉneZ-Ruano / Juan DE LA Riva (2019a): «Fire regime dynamics in mainland Spain. Part 1: Drivers of change», Science of The Total Environment, 721, 135841.

Rodrigues, Marcos / Fermín AlCASENA / Cristina VeGA-GARCÍA (2019b): «Modeling initial attack success of wildfire suppression in Catalonia, Spain», Science of Total Environment, 666, 915-927. 
José A. Vega, Stéfano Arellano-Pérez, Cristina Fernández, Teresa Fontúrbel e Ana Daría Ruiz

Rodrigues, Marcos / Fermín Alcasena / Pere Gelabert / Cristina Vega-García (2020): «Geospatial Modeling of Containment probability for escaped wildfires in a Mediterranean region", Risk Analysis, 40:9, 1762-1779.

Rodríguez y Silva, Francisco / Juan Ramón Martínez Molina / Armando GonZÁlez-Cabán (2014): "A methodology for determining operational priorities forprevention and suppression of wildlandfires», International Journal of Wildland Fire, 23:4, 544-554.

Roos, Christopher I. / Andrew C. ScotT / Claire M. BelCher / William G. ChAloner / Jonathan Aylen / Rebecca Bliege Bird / Michael R. Coughlan / Bart R. JHOnson / Fay H. Johnston / Julia McMoRROW / Toddy STEELman / The Fire and Mankind Dicussion Group (2016): «Living on a flammable planet: interdisciplinary, cross scalar and varied cultural lessons, prospects and challenges», Philosophical Transactions Royal Society, B 371:20150469.

Rothermel, Richard C. (1983): How to Predict the Spread and Intensity of Forest and Range Fires, General Technical Report INT-143, Ogden, UT, U.S. Department of Agriculture, Forest Service, Intermountain Forest and Range Experiment Station.

Rothermel, Richard C. (1991): Predicting Behavior and Size of Crown Fires in the Northern Rocky Mountains, Research Paper INT-438, Ogden, UT, U.S. Department of Agriculture, Forest Service, Intermountain Research Station.

Rothermel, Richard C. / Ralph A. Wilson / Glen A. Morris / Stephen S. SACKetT (1986): Modeling moisture content of fine dead wildland fuels: input to the BEHAVE fire prediction system, Research Paper INT-359, Ogden, UT, U.S. Department of Agriculture, Forest Service, Intermountain Research Station.

Rudel, Thomas K. / Oliver T. COOMEs / Emilio Morán / Frederic ACHARd / Arild Angelsen / Jianchu XU / Eric LAMBIN (2005): «Forest transitions: towards a global understanding of land use change», Global Environmental Change, 15:1, 23-31.

Rudel, Thomas K. / Laura SCHneIder / María Uriarte (2010): «Forest transition: an introduction», Land Use Policy, 27:2, 95-99.

Ruiz-GonzÁlez, Ana D. / José A. Vega (2007): Modelos de predicción de la humedad de los combustibles muertos: fundamentos y aplicación, Madrid, Instituto Nacional de Investigación y Tecnología Agraria y Alimenticia. (Monografías INIA: Serie Forestal, 15).

Ruiz-Mirazo, Jabier / Ana Belén Robles / José Luis GonZÁLEZ-Rebollar (2011): «Two-year evaluation of fuelbreaks grazed by livestock in the wildfire prevention program in Andalusia (Spain)", Agriculture Ecosystems and Environment, 141, 13-22.

S/A (2019): "The Complexities of Wildfires», Nature Geoscience, 12, 81.

SAlis, Michele / Liliana Del Guidice / Bachisio ArCa / Alan A. Ager / Fermín AlCASEnA-Urdíroz / Olga LOZANO / Valentina BACCIU / Donatella SpANO / Pierpaolo DuCE (2018): «Modeling the effects of different fuel treatment mosaics on wildfire spread and behavior in a Mediterranean agro-pastoral area», Journal of Environmental Management, 212, 490-505.

San-Miguel-Ayanz, Jesús / José Manuel Moreno / Andrea Camia (2013): "Analysis of large fires in European Mediterranean landscapes: Lessons learned and perspectives», Forest Ecology and Management, 294, 11-22.

SAn-Miguel-Ayanz, Jesús / Tracy Durrant / Roberto Boca / Giorgio Libertà / Alfredo Branco / Daniele DE Rigo / Davide Ferrari / Pieralberto Maianti / Tomàs ArTés Vivancos / Hugo Costa / 
Fabio Lana / Peter Löffler / Daniel Nuijten / Anders Christofer Ahlgren / Thais Leray (2018): Forest Fires in Europe, Middle East and North Africa 2017, UE JRC, Ispra, Italy (DOI: 10.2760/663443). SCHMidT, David A. / Alan H. TAYLOR / Carl N. Skinner (2008): «The influence of fuels treatment and landscape arrangement on simulated fire behavior, Southern Cascade Range, California», Forest Ecology and Managemen, 255, 3170-3184.

Schoennagel, Tania / Jennifer K. Balch / Hannah Brenkert-Smith / Philip E. Dennison, Brian J. Harvey / Meg A. Krawchuk / Nathan Mietkiewicz / Penelope Morgan / Max A. Moritz / Ray Rasker / Monica G. Turner / Cathy Whitlock (2017): «Adapt to more wildfire in western North American forests as climate changes», Proc. Natl. Acad. Sci. USA, 114, 4582-4590.

ScotT, Andrew C. (2018): Burning Planet: The Story of Fire through Time, Oxford, Oxford University Press.

ScotT, Andrew C. / David M. J. S. Bowman / William J. Bond / Stephen J. Pyne / Martin E. AlexanDER (2014): Fire on earth: an introduction, Chichester (UK), Wiley-Blackwell.

SeIjo, Francisco (2005): «The Politics of Fire: Spanish Forest Policy and Ritual Resistance in Galicia, Spain», Environmental Politics, 14:3, 380-402.

SEIJO, Francisco (2009): «Who Framed the Forest Fire? State Framing and Peasant Counter-Framing of Anthropogenic Forest Fires in Spain Since 1940», Journal of Environmental Policy and Planning, 11:2, 103-128.

SeIjo, Francisco / Robert Gray (2012): «Pre-industrial anthropogenic fire regimes in transition: the case of Spain and its implications for fire governance in Mediterranean type biomes», Human Ecology Review, 19:1, 58-69.

Sil, Ângelo / João C. Azevedo / Paulo Fernandes / Adrián Regos / Ana S. Vaz / João P. Honrado (2019a): «(Wild)fire is not an ecosystem service», Frontiers in Ecology and the Environment, 17, 429-430.

Sil, Ângelo / Paulo Fernandes / Ana Paula Rodrigues / Joaquim M. Alonso / João P. Honrado / Ajith Perera / João C. AzeVEdo (2019b): «Farmland abandonment decreases the fire regulation capacity and the fire protection ecosystem service in mountain landscapes», Ecosystem Services, 36, 100908.

SineIro GarCía, Francisco (2006): «As causas estruturais dos incendios forestais en Galicia», en Francisco Díaz-Fierros / Plácido Baamonde (coords.), Os incendios forestais en Galicia, Santiago de Compostela, Consello da Cultura Galega, 77-92.

Smith, Jo (2010): Agroforestry: Reconciling Production with protection of the environment. A Synopsis of Research Literature, The Organic Research Centre, Elm Farm, Hamstead Marshall, Newbury, Berkshire.

SMITH, Melinda D. (2011): «An ecological perspective on extreme climatic events: a synthetic definition and framework to guide future research», Journal of Ecology, 99, 656-663.

SneEuwJagt, Richard J. / George B. PeEt (1985): Forest Fire Behaviour Tables for Western Australia, Perth, Western Australia, Department of Conservation and Land Management.

Sobrino, Jose Antonio / Rafel Llorens / Cristina Fernández / José M. Fernández-Alonso / José Antonio VeGA (2019): «Relationship between soil burn severity in forest fires measured in situ and through spectral indices of remote detection", Forests, 10:5, 457.

Sousa, Pedro M. / Ricardo M. Trigo / Mário G. Pereira / Joaquín Bedía / José M. Gutiérrez (2015): «Different approaches to model future burnt area in the Iberian Peninsula», Agricultural and Forest Meteorology, 202, 11-25.

Spies, Thomas A. / Eric M. White / J. D. Kuine / A. Paige Fischer / Alan Ager / John Bailey / John Bolte / Jennifer Koch / Emily Platt / Chritine S. Olsen / Derric Jacobs / Shindler BruCE / Michelle 
M. STEEM-AdAms / Roger Hammer (2014): «Examining fire-prone forest landscapes as coupled human and natural systems", Ecology and Society, 19:3, art. 9.

Steelman, Toddi A. (2016): «US wildfire governance as social-ecological problem», Ecology and Society, 21:4, art. 3.

STEelman Toddi A. / Sarah McCaffrey (2011): «What is limiting more flexible fire management: public or agency pressure?», Journal of Forestry, 109:8, 454-461.

Stevens-Rumann, Camile S. / Kerry B. Kemp / Phillip E. Higuera / Brian J. Harvey / Monica T. Rother / Daniel C. Donato / Penelope Morgan / Thomas T. Veblen (2018): «Evidence for declining forest resilience to wildfire under climate change», Ecology Letters, 21, 243-252.

TÁbara, David / David SAURI / Rufí CERDAN (2003): «Forest fire risk management and public participation in changing socio-environmental conditions: A case study in a Mediterranean region", Risk Analysis, 23, 249-260.

TABoada, Ángela / Reyes TÁrrega / Elena Marcos / Luz Valbuena / Susana SuÁrez-SeOAne / Leonor CALVO (2017): «Recruitment and growth by altering plant interactions in fire-prone ecosystems», Forest Ecology and Management, 402, 63-75.

Tedim, Fantina / Vittorio LeONE / Gavriil XANTHOPOulos (2015): «Wildfire risk management in Europe: the challenge of seeing the "forest" and not just the "trees"”, en Proceedings of the 13th International Wildland Fire Safety Summit \& 4 th Human Dimensions of Wildland Fire, Managing Fire, Understanding Ourselves: Human Dimensions in Safety and Wildland Fire, Missoula, MT, International Association of Wildland Fire, 213-238.

Tedim, Fantina / Vittorio. LeOne / Gavriil Xanthopoulos (2016): «A wildfire risk management concept based on a social-ecological approach in the European Union: fire Smart Territory», International Journal of Disaster Risk Reduction, 18, 138-153.

TEDIM, Fantina / Vittorio LEONE (2017): «Enhancing resilience to wildfire disasters: from the "war against fire" to "coexist with fire" ", en D. Paton / D. Johnston (eds.), Disaster resilience: an integrated approach, Springfield, IL, US, Charles C Thomas Publisher, 362-383.

Tedim, Fantina / Vittorio Leone / Malik Amraoui / Christophe Bouillon / Micahel C. Coughlan / Giuseppe Delogu / Paulo Fernandes / Carmen Ferreira / Sarah McCaffrey / Tara K. McGee / Joana Parente / Douglas Paton / Mario G. Pereira / Luis M. Ribeiro / Domingos X. Viegas / Gavriil Xanthopoulos (2018): «Defining extreme wildfire events: difficulties, challenges, and impacts», Fire, $1: 1,9$.

Tedim, Fantina / Sarah M. McCaffrey / Vittorio Leone / Giuseppe M. Delogu / Marc Castellnou / Tara K. McGeE / José ARANHA (2019): «What can we do differently about the extreme wildfire problem: an overview», en F. Tedim / V. Leone / T. McGee (eds.), Extreme wildfires and disasters, Elsevier, 233-263.

Tedim, Fantina / Vittorio LeONE (2020): «The dilemma of wildfire definition: what it reveals and what it implies», Frontiers in Forest and Global Change, 3:553116.

Thompson, Matthew P. / Christopher Dunn / Dave Calkin (2015): «Wildfires: systemic change required», Science, 350:6263, 920.

Thompson, Matthew P. / Phil Bowden / April Brough / Joe H. Scott / Julie GiLbertson-Day / Alan TAYLOR / Jennifer ANDERSON / Jessica HAAS (2016): «Application of wildfire risk assessment results to wildfire response planning in the southern Sierra Nevada, California, USA», Forests, 7:3, 64. 
Thompson, Matthew P. / Donald G. McGregor / Christopher J. Dunn / David E. Calkin / J. Phipps (2018a): «Rethinking the wildland fire management system», Journal of Forestry, 116, 382-390.

Thompson Matthew P. / Zhiwei Liu / Yu Wei / Michael D. CAgGiano (2018b): «Analyzing wildfire suppression difficulty in relation to protection demand», Environmental Risks, Chapter 3, 45-64, London, IntechOpen.

Thompson, Matthew P. / Yu Wei / David E. Calkin / Christopher D. O'Connor / Christopher J. Dunn / Nathaniel M. Anderson / John S. Hogland (2019): «Risk Management and Analytics in Wildfire Response», Current Forestry Reports, 5, 226-239.

Trigo, Ricardo M. / Pedro M. Sousa / Mário G. Pereira / Domingo Rasilla / Célia M. Gouveia (2013): «Modelling wildfire activity in Iberia with different atmospheric circulation weather types», International Journal of Climatology, 36:7, 2761-2778.

Turco, Marco / Jost von Hardenberg / Amir AghaKouchaK / María del Carmen Llasat / Antonello Provenzale / Ricardo M. Trigo (2017): «On the key role of droughts in the dynamics of summer fires in Mediterranean Europe», Scientific Reports, 7:1, 81:1-81:10.

Turco, Marco / Juan José Rosa-CÁnovas / Joaquín Bedía / Sonia Jerez / Juan Pedro Montávez / Maria Carmen Llasat / Antonello Provenzale (2018): «Exacerbated fires in Mediterranean Europe due to anthropogenic warming projected with non-stationary climate-fire models», Nature Communications, 9:1, 1-9.

Turner, Monica G. / William H. Romme (1994): «Landscape dynamics in crown fire ecosystems», Landscape Ecology, 9, 59-77.

Urbieta, Itziar R. / Gonzalo Zavala / Joaquín Bedía / José Manuel GutiérRez / Jesús San Miguel-Ayanz / Andrea Camia / Jon E. Keeley / José M. Moreno (2015): «Fire activity as a function of fire-weather seasonal severity and antecedent climate across spatial scales in southern Europe and Pacific western USA», Environmental Research Letters, 10:11, 114013.

Vallejo, Vicente R. / José A. AllozA (1998): «The restoration of burned lands: the case of Eastern Spain», en J. M. Moreno (ed.), Large Forest Fires, Backhuys Publishers, Leiden, The Netherlands, 91-108.

VAllejo Vicente R. / James Aronson / Juli G. Pausas / Jordi G. Cortina (2004): «Restoration of Mediterranean Woodlands», en J. van Andel / J. Aronson (eds.), Restoration Ecology from a European Perspective, Chapter 14, Blackwell Science.

Van Wagner, Carol E. (1987): Development and Structure of the Canadian Forest Fire Weather Index System, Ottawa, ON, Canadian Forestry Service. (Forestry Technical Report, 35).

Vega, José A. / Jean Charles Valette / Francisco Rego / Carmen Hernando Lara / Dominique Gillon / João Ventura / Salvador Bara / Veronique Gomendy / Herminio Botelho / Mercedes Guijarro / C. Houssard / Luis Ruas / Pedro Cuiñas / Jean Marechal / José Mendes-Lopes / Ramón Díez / Paulo Fernandes / Juan A. Santos / María J. Rozados / M. Carmen Beloso (1994): «Forest fire prevention through prescribed burning: an international cooperative project carried out in the European STEP program", en Domingos Xavier Viegas (ed.), 'Proceedings of the 2nd International Conferenceon Forest Fire Research', 21-24 November 1994, Coimbra, Portugal, 75-84.

Vega, José A. / Pedro Cuiñas / Ma Teresa Fontúrbel / Cristina Fernández (2000a): «Planificar la prescripción para reducir combustibles y disminuir el impacto sobre el suelo en las quemas prescritas", Cuadernos de la Sociedad Española de Ciencias Forestales, 9, 189-198. 
José A. Vega, Stéfano Arellano-Pérez, Cristina Fernández, Teresa Fontúrbel e Ana Daría Ruiz

Vega, José A. / Pedro Cuiñas / M. Teresa Fontúrbel / Cristina Fernández (2000b): «Planificar la prescripcion para reducir combustibles y disminuir el impacto sobre el suelo en las quemas prescritas», Cuad. Soc. Esp. Cienc. Forestales, 9, 189-198.

Vega, José A. / Pedro Pérez-Gorostiaga / Pedro Cuiñas / Teresa Fontúrbel / Cristina Fernández (2001): Manual de queima prescrita para matogueiras de Galicia, Consellería de Medio Ambiente, Xunta de Galicia.

Vega, José A. / Cristina Fernández / Pedro Pérez-Gorostiaga / Teresa Fontúrbel (2008): «The influence of fire severity, serotiny, and post-fire management on Pinus pinaster Ait. recruitment in three burnt areas in Galicia (NW Spain)», Forest Ecology and Management, 256, 1596-1603.

Vega, José A. / Cristina Fernández / Enrique Jiménez / Ana D. Ruiz (2009a): «Impacto dun escenario de cambio climático sobre o perigo de incendios forestais en Galicia», en Vicente Pérez Muñuzuri / Marisa Fernández Cañamero / José Luis Gómez Gesteira (coords.), Evidencias e impactos do cambio climático en Galicia, Santiago de Compostela, Xunta de Galicia, 583-607.

Vega, José A. / Cristina Fernández / Enrique Jiménez / Ana D. Ruiz (2009b): «Evidencias de cambio climático en Galicia a través das tendencias dos índices de perigo de incendios forestais», en Vicente Pérez Muñuzuri / Marisa Fernández Cañamero / José Luis Gómez Gesteira (coords.), Evidencias e impactos do cambio climático en Galicia, Santiago de Compostela, Xunta de Galicia, 173-194.

Vega, José A. / Cristina Fernández / Pedro Pérez-Gorostiaga / María Teresa Fontúrbel (2010a): «Response of maritime pine (Pinus pinaster Ait.) recruitment to fire severity and post-fir management in a coastal burned area in Galicia (NW Spain)», Plant Ecology, 206, 297-308.

Vega, José A. / María T. Fontúrbel / Cristina Fernández / Pedro Pérez-Gorostiaga / Enrique JiméNEZ (2010b): Selvicultura preventiva de incendios forestales en formaciones de matorral del noroeste de España: análisis comparativo de la eficacia de los tratamientos y de los efectos edáficos producidos, Centro de Investigación Forestal Lourizán, Xunta de Galicia.

Vega, José A. / Teresa Fontúrbel / Cristina Fernández / Antonio Arellano / Montserrat Díaz-RaviNa / Ma Tarsy Carballas / Ángela Martín / Serafín GonZÁlez-Prieto / Agustín Merino / Elena BENITO (2013a): Acciones urgentes contra la erosión en áreas forestales quemadas: guía para su planificación en Galicia, Xunta de Galicia / Ministerio de Economía y Competitividad.

Vega, José A. / Teresa Fontúrbel / Agustín Merino / Cristina Fernández / Andrea Ferreiro / Enrique JiMÉNEZ (2013b): «Testing the ability of visual indicators of soil burn severity to reflect changes in soil chemical and microbial properties in pine forests and shrubland", Plant and Soil, 369:1-2, 73-91.

Vega, José A. / Ricardo VéLeZ (eds.) (2000): «Taller sobre Empleo de Quemas Prescritas», Pontevedra, Sociedad Española de Ciencias Forestales, 283 pp. ISSN 1575-2410.

Vega Hidalgo, José Antonio (2003): «Regeneración del género Pinus tras incendios», Cuadernos de la Sociedad Española de Ciencias Forestales, 15, 59-68.

Vega Hidalgo, José Antonio (2015): «Nuevos retos y oportunidades de mejora en la lucha contra incendios forestales y sus consecuencias", Cuadernos de la Sociedad Española de Ciencias Forestales, 39, 73-95.

VÉLEZ, Ricardo (1986): «Incendios forestales y su relación con el medio rural», Revista de Estudios Agrosociales, 136, 195-224.

VÉlEz, Ricardo (1991): «Los incendios forestales y la política forestal», Revista de Estudios Agrosociales, 158, 83-105.

VÉLEZ, Ricardo (2005): La población rural en la prevención de incendios forestales, Documento de Trabajo sobre Protección Forestal FFM/4/E, Roma, FAO. 
VéLEZ, Ricardo (2009): «Cambio global e incendios forestales: perspectivas en la Europa Meridional», Recursos Rurais, 5, 49-54.

VIEgas, Domingos X. / Raul M. ReIs / Miguel G. CruZ / Maria T. VIEGAS (2004): «Calibração do Sistema Canadiano de Perigo de Incêndio para Aplicação em Portugal», Silva Lusitana, 12:1, 77-93.

Vilar del Hoyo, Lara / Pilar Martín / Andrea CAmia (2009): «Analysis of human-caused wildfire occurrence and land use changes in France, Spain and Portugal», en Emilio Chuvieco / Rosa Lasaponara (eds.), Proceedings of the VII International EARSeL Workshop - Advances on Remote Sensing and GIS Applications in Forest Fire Management, Potenza, Italy, 85-89.

VINEY, Neil R. / Thomas J. HATTON (1989): «Assessment of existing fine fuel moisture models applied to Eucalyptus litter", Australian Forestry 52:2, 82-93.

WeI, Yu (2012): «Optimize landscape fuel treatment locations to create control opportunities for future fires", Canadian Journal of Forest Research, 42, 1002-1014.

Wei, Yu / Douglas B. Rideout / Andrew G. Kirsch (2008): «An optimization model for locating fuel treatments across a landscape to reduce expected fire losses», Canadian Journal of Forest Research, 38, 868-877.

Wildland Fire Leadership Council (2014): The National Strategy: The Final Phase in the Development of the National Cohesive Wildland Fire Management Strategy, Washington, DC.

Wolfslehner, Bernhard / Stefanie Linser / Helga PÜlzl / Annemarie Bastrup-Birk / Andrea Camia / Marco MARCHETTI (2016): Forest bioeconomy - a new scope for sustainability indicators, From Science to Policy 4, European Forest Institute.

Wotton, B. Michael (2008): «Interpreting and using outputs from the Canadian Forest Fire Danger Rating System in research applications», Environmental and Ecological Statistics, 16:2, 107-131.

Xanthopoulos, Gavriil (2008): «People and the Mass Media during the fire disaster days of 2007 in Greece», The International Bushfire Research Conference Adelaide, Australia.

Xanthopoulos, Gavriil / Vittorio, Leone / Giuseppe M. Delogu (2019): «The suppression model fragilities: The "firefighting trap"”, en F. Tedim / V. Leone / T. McGee (eds.), Extreme Wildfire Events and Disasters Root Causes and New Management Strategies, Elsevier, 135-153.

Xunta de Galicia. Consellería do Medio Rural (2019): PLADIGA 2019, Santiago de Compostela.

Yebra, Marta / Philip E. Dennison / Emilio Chuvieco / David Riaño / Philip Zylstra / E. Raymond HunT / F. Mark DANSON / Yi QI / Sara JURDAO (2013): «A global review of remote sensing of live fuel moisture content for fire danger assessment: Moving towards operational products», Remote Sensing of Environment, 136, 455-468. 
FACTORES ESTRUTURAIS QUE CONTRIBÚEN AO PROBLEMA DOS INCENDIOS EN GALICIA: MUDANZAS NO MEDIO RURAL E DEFICIENCIAS NA XESTIÓN DO TERRITORIO

Edelmiro López Iglesias

Grupo ECOAGRASOC

Departamento de Economía Aplicada

Universidade de Santiago de Compostela 



\section{OS INCENDIOS FORESTAIS EN GALICIA E A RESPOSTA DAS POLÍTICAS PÚBLICAS; DIAGNÓSTICO INICIAL}

Os incendios forestais emerxeron como problema grave en Galicia nas décadas de 1970 e 1980. Nestes dous decenios o número de lumes, aínda que con oscilacións, experimentou un incremento continuo, ao pasar de 1000 anuais a comezos dos 70 a máis de 4000 a finais dos 80 . E iso acompañouse dunha tendencia tamén crecente da superficie queimada, que superou en catro anos as 100000 hectáreas, até alcanzar un máximo de 200000 ha en 1989.

\subsection{As políticas aplicadas desde 1990; balance dos resultados}

Coa consolidación en España do Estado autonómico, as competencias en prevención e extinción de incendios pasaron a estar esencialmente en mans das comunidades autónomas. Pois ben, a resposta da Xunta de Galicia ante o problema dos incendios centrouse, a partir de 1990, na creación dun dispositivo específico de extinción, o que orixinou un forte crecemento do gasto público nese dispositivo (Sineiro 2006). O orzamento dedicado a este fin aumentou de 6 millóns de euros en 1989 até 69,6 en 2006, para alcanzar un máximo de 129,8 millóns en 2007, despois da crise incendiaria de 2006. Na última década a cifra tendeu a estabilizarse en arredor de 100 millóns anuais ${ }^{1}$.

\footnotetext{
1 Tomamos os datos até 2005 de Sineiro (2006). Para o período 2003-2017 as cifras corresponden ao orzamento da Xunta de Galicia para o programa 551B, «Accións preventivas e infraestrutura forestal», ou análogos, segundo a serie recompilada no web <silvicultor.blogspot.com>.

Somos conscientes das limitacións deses datos: no programa 551B están incluídos gastos en medidas preventivas; no sentido contrario, non se computa o gasto en extinción doutros departamentos da Xunta de Galicia, da Administración central e das corporacións locais. Ademais, trátase de orzamentos iniciais, non do gasto executado. A pesar de todo, serven como indicación das tendencias.
} 
A prioridade outorgada á extinción acompañouse dunha escasa atención á prevención estrutural e á ordenación e xestión forestal. O que se reflicte nun dato: en contraste coas contías dedicadas ao combate aos incendios, o orzamento da Xunta de Galicia para ordenación e produción forestal permanece estancado desde principios da década de 2000 en aproximadamente 60 millóns anuais.

Esa afirmación require certas matizacións. A máis relevante refírese aos anos 2006-2009, nos que asistimos ao intento de sentar as bases dunha nova política de prevención estrutural e de ordenación do monte. Ese intento, moi embrionario e incompleto, plasmouse en diferentes iniciativas: aprobación da Lei 3/2007 de prevención e defensa contra os incendios forestais de Galicia, e creación, co fin de impulsar a mobilización produtiva das terras, tanto agrarias como forestais, do Banco de Terras (2007) e das unidades de xestión forestal -UXFOR(2008). Pero desde 2010 tivo lugar un retorno ás políticas do período 1990-2005 , baseadas na confianza absoluta no dispositivo de extinción. De tal maneira que se eliminou a figura das UXFOR (substituídas polas SOFOR, cunha aplicación até agora case nula), o Banco de Terras quedou desactivado e se relaxaron as normas de prevención aprobadas en 2007, abandonando calquera impulso do seu cumprimento.

As estatísticas sobre a evolución do número de lumes e a superficie queimada mostran os logros, pero tamén os límites, desa política centrada na extinción. Podemos resumir así o que indican os datos (gráfico 1).

- O dispositivo de extinción permitiu reducir de modo significativo a superficie queimada no período 1990-2005. Pero esas medidas non lograron controlar o número de lumes, que continuou aumentando, nin tampouco puideron evitar que a superficie afectada alcanzase cifras importantes (por riba de 45000 ha) nos anos de condicións meteorolóxicas desfavorables.

- Nos anos 2006-2009, coincidindo coas novas medidas aprobadas despois da crise incendiaria de 2006, asistimos a unha importante inflexión, plasmada na diminución substancial do número anual de lumes (de 12000 a 4000).

- Despois diso, a evolución recente (2010-2016) aparecía definida por unha tendencia á estabilización tanto do número de lumes (ao redor de 4000 anuais) como da superficie afectada (de 15000 a 20000 ha ao ano). 
Gráfico 1. Evolución do número de lumes e da superficie afectada por incendios forestais. Galicia, 1976-2019

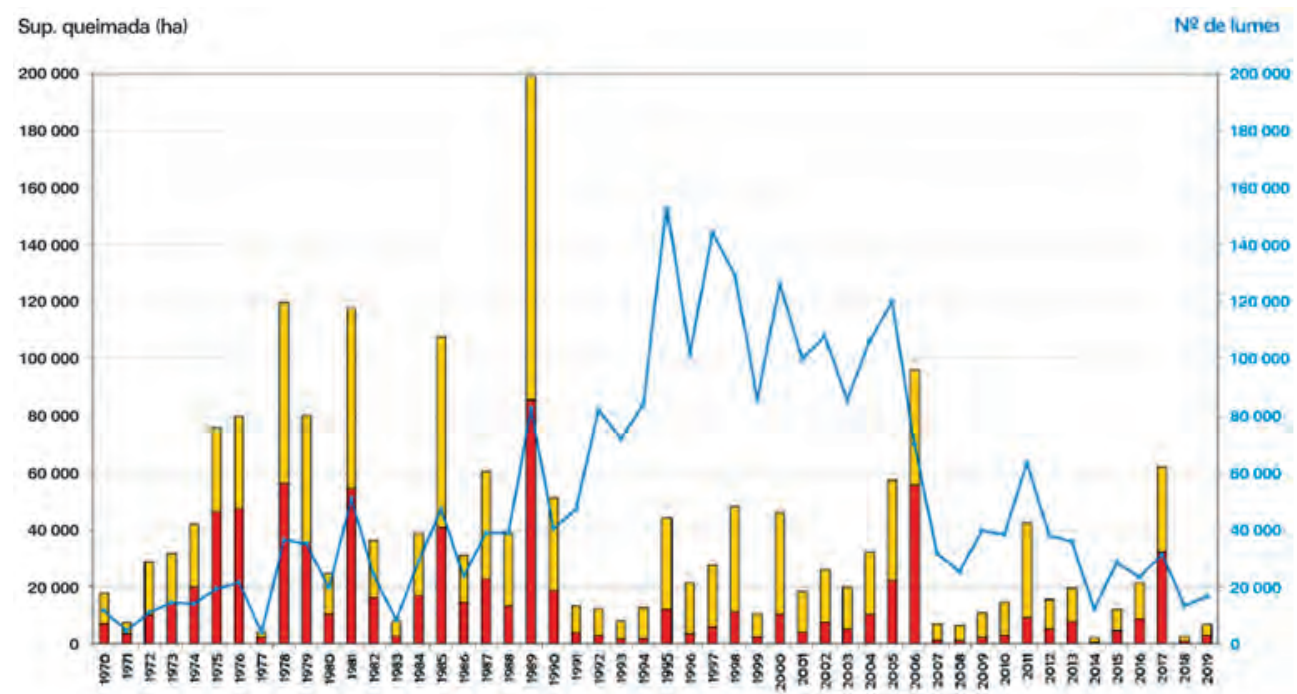

S. A. Q.: superficie arborada queimada. S. R. Q.: superficie rasa queimada.

Fonte: Consellería do Medio Rural (2020): PLADIGA 2020

O control aparente do problema que parecían suxerir eses datos saltou polos aires, porén, coa crise incendiaria de 2017 , cando só nunha semana de outubro arderon unhas 50000 ha e no conxunto do ano máis de 60000 . Globalmente, a experiencia das tres últimas décadas, e en especial a nova onda de incendios sufrida en outubro de 2017, pon de manifesto os límites dunha política centrada na extinción e a necesidade de abordar os factores estruturais que están na orixe do problema. Co termo «factores estruturais» referímonos principalmente ás deficiencias na ordenación e xestión das superficies forestais e, globalmente, do territorio rural, agravadas polo incumprimento das medidas establecidas na normativa de prevención. A un nivel máis xeral, as causas últimas de que os incendios se convertesen nun problema crónico hai que buscalas nas mudanzas experimentadas desde mediados do século XX polo noso medio rural e, ligado a iso, nas modificacións operadas nos usos do solo. 
Eses factores estruturais están na orixe de moitos incendios. Ademais, unha vez iniciados os lumes, favorecen a súa expansión, debido á acumulación de combustible e ás características das masas forestais. E dificultan tamén as tarefas de extinción, ao obrigar a concentrar os medios na defensa das casas e dos núcleos de poboación.

Con isto non pretendemos soster que eses fenómenos constitúan a causa única do problema dos incendios. Se queremos ter un panorama desas causas, hai que engadir como mínimo outros dous factores: as condicións climáticas, que inflúen no crecemento da vexetación e na súa sequidade en certas épocas do ano, e determinadas prácticas que seguen existindo no noso medio rural, que poden resumirse nunha certa promiscuidade no uso do lume para o control da vexetación. Pero, sen o explicaren todo, os fenómenos analizados a continuación constitúen factores estruturais que contribúen á intensidade que alcanza o problema, especialmente en certas zonas do territorio galego.

\subsection{O novo contexto derivado do cambio climático; leccións da experiencia de 2017 en Portugal (e tamén en Galicia)}

O problema dos incendios adquire maior urxencia no novo contexto derivado do cambio climático. Neste sentido, hai leccións importantes que extraer da experiencia de 2017 en Portugal e, de modo menos grave, tamén en Galicia.

As alteracións climáticas incrementan de forma notable -en concreto, no cuadrante noroeste da Península Ibérica- o risco de incendios de grande intensidade que superan rapidamente a capacidade de calquera dispositivo de extinción. Con condicións meteorolóxicas adversas (temperatura, baixa humidade, vento), que van ser máis frecuentes, se existe unha elevada acumulación de combustible no territorio, as oportunidades de controlar os incendios limítanse á fase inicial (para os incendios de outubro de 2017 en Portugal, entre 3 e 17 minutos desde o inicio do lume [Comissão Técnica Independente 2018]). Polo tanto, no referido ao dispositivo de extinción, o importante non vai ser a acumulación de máis medios (avións, máquinas, persoas), senón a capacidade de prever eses episodios (máis coñecemento), a rapidez da resposta e contar con medios dispostos para o ataque inicial (estratexia de anticipación). 
Dado que os factores climáticos son un dato, debemos centrarnos no que depende de nós: 1) a redución do combustible acumulado, o que remite á xestión do territorio e da paisaxe, e 2) a diminución do número de lumes, o que pasa por modificar certas prácticas que continúan arraigadas no noso medio rural. Por un lado, no contexto actual adquire unha importancia decisiva a redución do combustible acumulado. $\mathrm{O}$ que nos leva a tres cuestións: a porcentaxe de superficie dedicada a áreas arborizadas, a selección de especies forestais e a súa continuidade no territorio, e o control da vexetación arbustiva nos espazos forestais (existencia ou non de xestión silvícola). De forma complementaria, nos períodos de máximo risco é fundamental un control estrito do uso do lume, para o que necesitamos mudar certas prácticas que subsisten no noso medio rural, que poden resumirse nunha promiscuidade no uso do lume para o control da vexetación.

\section{A DESESTRUTURACIÓN DO MEDIO RURAL E AS DEFICIENCIAS NOS USOS DA TERRA COMO CAUSAS ESTRUTURAIS DOS INCENDIOS}

\subsection{Acelerado declive e mudanzas socioeconómicas das áreas rurais}

A mediados do século XX, Galicia era aínda unha sociedade cun forte predominio rural e cun medio rural esencialmente agrario. Resumido en cifras, en 1950, segundo o censo de poboación dese ano, o $80 \%$ da poboación vivía nese ámbito (entidades de menos de 2000 habitantes) e dela o $90 \%$ traballaba na agricultura, o que facía que o $70 \%$ da poboación ocupada total tivese a súa actividade exclusiva ou principal no sector agrario.

Se a agricultura constituía a base da sociedade rural, e da maior parte da sociedade galega, a realidade que encontrabamos neste sector pode sintetizarse en dúas notas: unha estrutura de pequenos agricultores que accederan tardiamente, nos 70 anos e anteriores, á plena propiedade das terras; uns sistemas produtivos caracterizados pola súa intensidade en man de obra e a limitada utilización de factores de produción de orixe industrial, un sistema agrario que facía un uso intensivo do factor traballo e estaba baseado nun modelo de policultivogandaría, ademais de ter un soporte fundamental nas terras de monte. 
Esa realidade mudou dun xeito radical nos últimos setenta anos e o motor das transformacións foi a acelerada caída do emprego agrario. A poboación ocupada no sector reduciuse no período 1950-2019 en case un $95 \%$ (de 827000 a 49900 persoas). Só nos últimos trinta e cinco anos, no período transcorrido desde a integración na Unión Europea, esa redución foi de case o 90 \%: de 415100 ocupados en 1985 a 49900 en 2019. Iso levou a unha diminución paralela do seu peso relativo no emprego total: do $70 \%$ en 1950 e preto do $40 \%$ aínda en 1985 ao 4,5\% na actualidade, unha cifra similar á media da UE-28. Galicia experimentou, pois, unha desagrarización tardía pero abrupta, ao concentrarse en sete décadas unha caída do emprego agrario que nos países máis desenvolvidos de Europa se fora graduando ao longo dun século e medio ou dous séculos (López Iglesias 2000 e 2019).

Esa acelerada diminución do emprego agrario tivo dous efectos. Por unha banda, orixinou un forte declive económico e demográfico das áreas rurais, que se acompañou da concentración da poboación e a actividade económica nas zonas urbanas, especialmente do Eixo Atlántico. Ao mesmo tempo, provocou unha crecente desagrarización do medio rural, unha redución da importancia da actividade agraria nestas áreas (López Iglesias e Pérez Fra 2004).

Como resultado, debemos destacar dúas notas que definen a realidade actual. A primeira é que Galicia xa non é un país, unha sociedade, rural. As áreas rurais seguen ocupando a maioría do territorio, pero nelas só habita unha porcentaxe reducida da poboación. A segunda nota é que ese medio xa non é só, nin sequera principalmente, agrario (ou agroforestal). A maioría dos seus residentes manteñen algunha vinculación coa propiedade ou co traballo da terra, pero só unha minoría ten a actividade principal na agricultura e no sector forestal (López Iglesias e Pérez Fra 2017).

Esta realidade aparece ilustrada polos datos sobre a clasificación dos municipios segundo o grao de urbanización, elaborada polo Instituto Galego de Estatística (IGE) tomando como base a metodoloxía proposta polo Eurostat (IGE 2017). Os que cabe catalogar como municipios rurais (as denominadas zonas pouco poboadas) ocupan en 2017 o $81,8 \%$ do territorio, pero só contan co $26,9 \%$ dos habitantes (cadro 1). E, dos afiliados á Seguridade Social residentes nestes municipios, unicamente o $14,0 \%$ teñen a ocupación principal en actividades agrarias e forestais; o 9,8 \% traballan na construción, o 15,6 \% na indus- 
tria e o $60,6 \%$ no sector servizos (cadro 2). Dentro deste conxunto, os concellos máis puramente rurais, os clasificados como zonas pouco poboadas de baixa densidade (ZPP baixa) cobren o 65,2 \% do territorio, pero neles só reside o $14,7 \%$ da poboación. E mesmo aquí os que traballan principalmente na agricultura e no sector forestal constitúen unha minoría, o 17,9\% dos afiliados á Seguridade Social, observándose un claro predominio dos ocupados nas diversas ramas dos servizos (57,9\%) (cadros 1 e 2 ).

Cadro 1. Distribución da superficie e a poboación de Galicia por zonas segundo o grao de urbanización (2017)

\begin{tabular}{|c|c|c|c|c|c|}
\hline & $\begin{array}{l}\text { Superficie } \\
\left(\mathrm{km}^{2}\right)\end{array}$ & $\begin{array}{l}\text { Habitantes } \\
\text { (2017) }\end{array}$ & $\%$ superficie & \% poboación & $\begin{array}{l}\text { Densidade } \\
\text { (hab./km²) }\end{array}$ \\
\hline ZDP & 982,3 & 987412 & 3,3 & 36,5 & 991,1 \\
\hline ZIP & 4398,7 & 993473 & 14,9 & 36,7 & 225,0 \\
\hline ZPP & 24194,4 & 727454 & 81,8 & 26,9 & 30,9 \\
\hline ZPP alta & 2281,1 & 201755 & 7,7 & 7,4 & 88,9 \\
\hline ZPP intermedia & 2632,3 & 126261 & 8,9 & 4,7 & 49,1 \\
\hline ZPP baixa & 19281,0 & 399438 & 65,2 & 14,7 & 21,5 \\
\hline Galicia & 29575,4 & 2708339 & 100,0 & 100,0 & 91,6 \\
\hline
\end{tabular}

ZDP: zonas densamente poboadas. ZIP: zonas intermedias. ZPP: zonas pouco poboadas.

Fonte: IGE

Cadro 2. Estrutura sectorial do emprego por tipos de zonas en Galicia (2017; afiliacións á Seguridade Social)

\begin{tabular}{|l|c|c|c|c|c|}
\hline & \multicolumn{1}{|l|}{ Total } & $\begin{array}{l}\text { Agricultura } \\
\text { e pesca }\end{array}$ & Construción & Industria & Servizos \\
\hline ZDP & 100,0 & 1,1 & 4,9 & 11,3 & 82,7 \\
\hline ZIP & 100,0 & 5,6 & 8,0 & 16,1 & 70,3 \\
\hline ZPP & $\mathbf{1 0 0 , 0}$ & $\mathbf{1 4 , 0}$ & $\mathbf{9 , 8}$ & $\mathbf{1 5 , 6}$ & $\mathbf{6 0 , 6}$ \\
\hline ZPP alta & 100,0 & 6,8 & 9,9 & 17,5 & 65,8 \\
\hline ZPP intermedia & 100,0 & 14,1 & 10,2 & 15,5 & 60,2 \\
\hline ZPP baixa & 100,0 & 17,9 & 9,7 & 14,5 & 57,9 \\
\hline Galicia & $\mathbf{1 0 0 , 0}$ & $\mathbf{6 , 1}$ & $\mathbf{7 , 3}$ & $\mathbf{1 4 , 2}$ & $\mathbf{7 2 , 4}$ \\
\hline
\end{tabular}

Fonte: IGE 
Que o rural xa non é só nin sequera principalmente agrario constátase tamén noutros indicadores, como a estrutura sectorial do PIB, as fontes de renda dos residentes e mesmo a xestión do territorio. Neste último aspecto, segundo a Enquisa sobre a estrutura das explotacións agrarias de 2016, os agricultores só xestionan hoxe en Galicia o $29 \%$ do territorio e unicamente o $21 \%$ está dedicado a cultivos e pastos (López Iglesias 2019).

En suma, nas últimas seis décadas, ao tempo que se producía un acelerado declive económico e demográfico do medio rural, asistimos a unha crecente desagrarización das áreas rurais, á desaparición da identidade «medio rural = agricultura» que, con matices, definía a realidade até mediados do século XX. Neste sentido, recollendo o apuntado para Portugal por F. Oliveira, o problema de fondo radica en que o rural galego xa non é (nin só nin principalmente) agrario, pero aínda non é «outra cousa» (Oliveira Baptista 2010). Podemos dicir tamén que "é moitas cousas á vez» (actividades económicas, demandas sociais, tipos de residentes), sen unha ordenación e articulación globais.

Esas transformacións tiveron dúas consecuencias con relevancia directa para o problema dos incendios. Por unha parte, levaron a unha forte diminución e un crecente envellecemento da poboación rural. Dada a acusada dispersión do hábitat, isto traduciuse na existencia de miles de aldeas cunha base demográfica cada vez máis débil e, polo tanto, cunha capacidade cada vez menor para xestionaren o territorio circundante. $\mathrm{O}$ outro efecto foi a desvinculación da maioría da poboación rural e dos propietarios de terras da xestión das súas superficies.

Esas tendencias globais esconden unha crecente heteroxeneidade interna, a nivel comarcal e municipal e mesmo entre as parroquias do mesmo concello. Heteroxeneidade que se constata simplemente con observar as densidades demográficas e que pode resumirse na configuración de «tres Galicias rurais» (Fernández e Peón 2017; mapa 1):

- Áreas rurais do Eixo Atlántico e outras comarcas periurbanas. Dominadas pola influencia dos mercados de traballo urbanos, caracterízanse por densidades de poboación relativamente elevadas e un importante dinamismo demográfico.

- Galicia central ou interior. Comarcas cunha base agraria, en especial gandeira, relativamente sólida, acompañada en moitos casos de cabeceiras comarcais de certa dimensión, o que posibilita o mantemento de densidades medias-baixas. 
- Zonas de montaña das serras orientais de Lugo, metade oriental e sur de Ourense e dorsal galega. Localizadas lonxe dos principais núcleos urbanos, é nestas zonas onde se constata un despoboamento máis acentuado e dificilmente reversible (densidades inferiores a 15 habitantes por quilómetro cadrado), asociado á extrema debilidade da súa base económica.

Mapa 1. Densidade de poboación a nivel municipal en Galicia (2016)

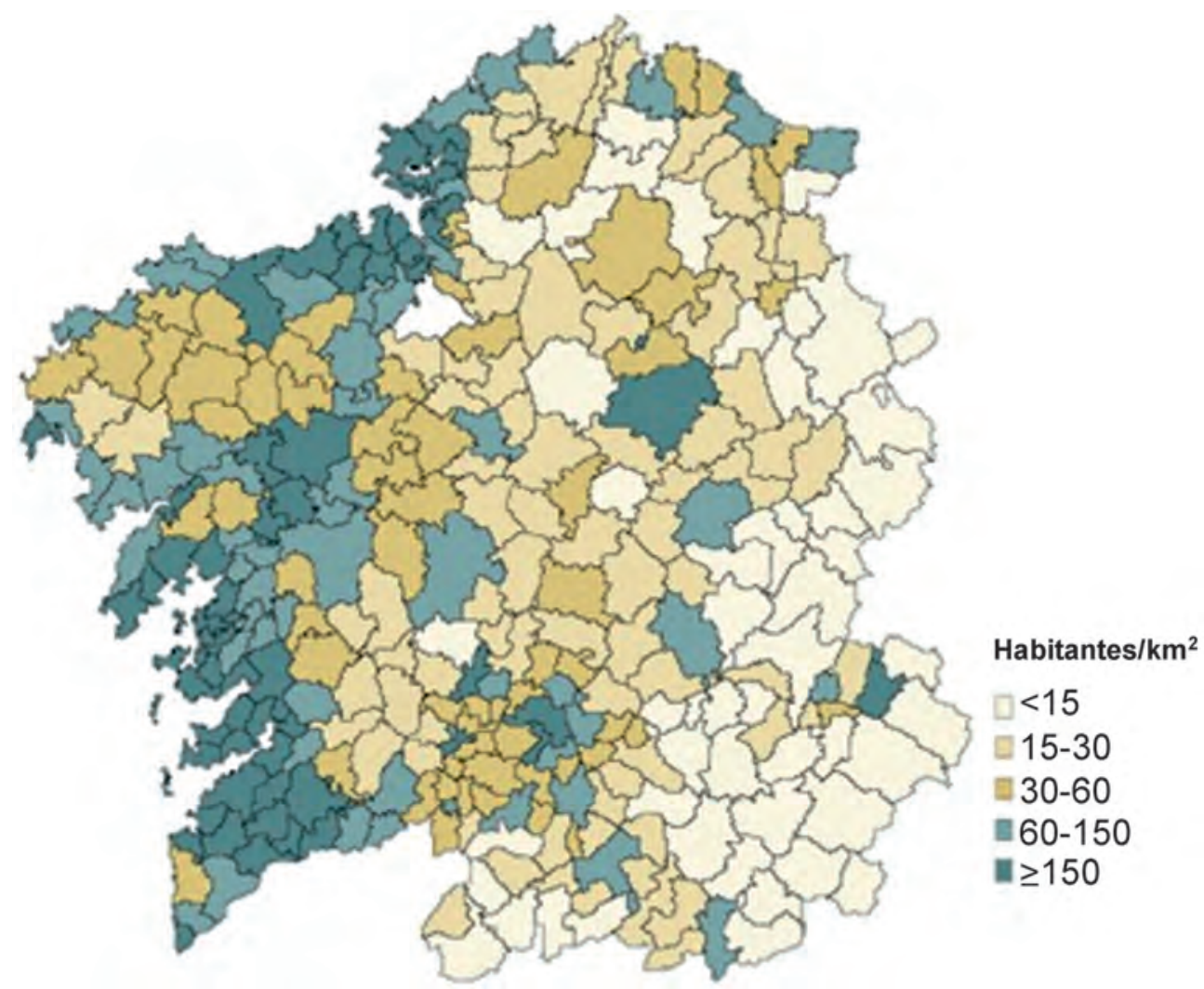

Fonte: IGE

Esa diferenciación dos espazos rurais obedece á dinámica empresarial local, pero tamén, cunha importancia crecente, aos fluxos de mobilidade diaria entre o lugar de residencia e o de traballo. Segundo o censo de poboación de 2001, o $37,8 \%$ das persoas ocupadas en Galicia traballaban nun municipio diferente ao 
de residencia, porcentaxe que en 2011 aumentou até o 42,8\%. No mapa 2 aparecen representados os fluxos de mobilidade diaria por razóns de traballo en 2001; destacan os constatados ao longo do Eixo Atlántico e as áreas rurais próximas, pero tamén se observa o poder de atracción das dúas capitais provinciais do interior (Lugo e Ourense) e de certas cabeceiras comarcais, o que contribúe ao sostemento demográfico das áreas rurais do seu contorno (mapa 2).

Mapa 2. Fluxos de mobilidade diaria entre o lugar de residencia e de traballo. Galicia, 2001

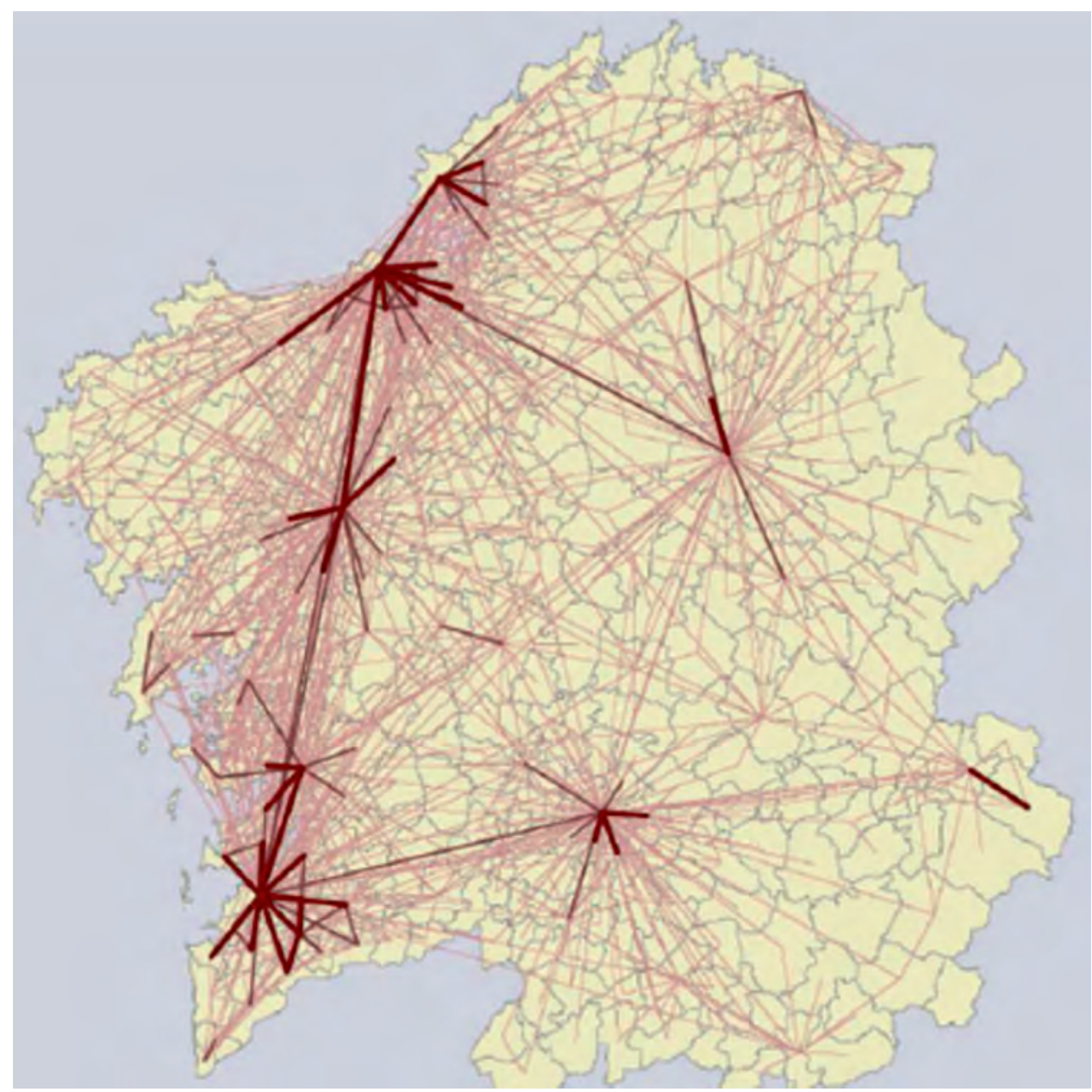

Fonte: IGVS (2008) 


\subsection{Usos da terra: mudanzas nos últimos 60 anos e situación actual}

As transformacións socioeconómicas que acabamos de resumir acompañáronse de fortes mudanzas nos usos do solo. Historicamente, no contexto do sistema agrario «tradicional» que se mantivo vixente en Galicia até mediados do século XX, o espazo agrario (dedicado de modo continuado a cultivos e pastos) ocupaba unha proporción pequena (ao redor do $25 \%$ ) do territorio, mentres que o restante $75 \%$ correspondía a terreos de monte. Isto constituía unha necesidade e un uso racional do espazo, dadas as importantes funcións que cumprían as terras de monte para as explotacións agrarias. Estas terras servían como espazo de cultivo temporal, eran empregadas para o pastoreo do gando e a obtención de leña e madeira, e fornecían a materia vexetal destinada a cama do gando que representaba a base para a obtención do abono orgánico que permitía manter a fertilidade das superficies de cultivo.

Ese uso diversificado das terras de monte facía que estas acumulasen pouco mato, debido ao pastoreo do gando e ao aproveitamento da vexetación para cama dos animais. Por outra banda, iso implicaba que, ademais da superficie dedicada de forma permanente a cultivos e pastos, unha boa parte das terras de monte puidesen ser incluídas nun concepto amplo de espazo agrario, ao seren obxecto dun aproveitamento agrogandeiro. $\mathrm{O}$ primeiro censo agrario realizado en España, en 1962, ilustra esa situación. Segundo esta estatística, había en Galicia 630000 hectáreas de cultivos e prados (o $21 \%$ da superficie xeográfica), pero ademais o censo contabilizaba 940000 ha de monte pastadas polo gando, polo que a superficie agraria en sentido amplo, o espazo obxecto dalgún aproveitamento agrícola ou gandeiro, se aproximaba a 1600000 ha, máis da metade (53\%) do territorio (López Iglesias et al. 2013).

Ese modelo de aproveitamento e xestión do territorio experimentou mudanzas substanciais nas seis últimas décadas. Mudanzas impulsadas pola redución da man de obra agraria, a intensa desaparición e concentración de explotacións e as transformacións na tecnoloxía e nos sistemas produtivos da agricultura; pero que se viron tamén moi condicionadas polo marco institucional e as políticas públicas: estas contribuíron a unha escasa mobilidade das terras agrarias, a unha forte expansión da superficie arborada e a un problema crecente de ordenación dos usos do solo (López Iglesias 1996). 
O resultado foron unhas tendencias que para o conxunto dos últimos sesenta anos poden resumirse en tres notas (López Iglesias et al. 2013):

- Notable retroceso do espazo agrario, debido a dous procesos: a forestación ou abandono da maior parte das terras pertencentes ás explotacións agrarias que deixaron de existir e a desaparición case completa do aproveitamento agrogandeiro das terras de monte.

- Forte expansión da superficie arborada, tanto nos terreos de propiedade particular como nos montes veciñais en man común.

- Aumento máis forte das superficies abandonadas.

Referíndonos ás terras de monte, a desaparición dos usos tradicionais deixou paso a unha situación definida por dous fenómenos. Por un lado, a expansión da superficie arborada, na que se consolidou un modelo forestal centrado nas especies de crecemento rápido e con escasa ou nula xestión da maioría das superficies. E, simultaneamente, o abandono de centos de miles de hectáreas, nas que crece de forma incontrolada o mato.

Esas tendencias continuaron, e nalgúns aspectos acentuáronse, nas décadas recentes, a partir da integración na UE. Concretamente, a análise realizada por Corbelle e Crecente (2014) mostra unhas mudanzas no período 1985-2005 definidas por catro tendencias: retroceso da superficie dedicada a cultivos e pastos, redución da superficie de mato, novo incremento da superficie arborada e, finalmente, expansión do territorio ocupado por infraestruturas e áreas urbanizadas (cadro 3). En suma, en palabras destes autores: urbanización, forestación e abandono.

Cadro 3. Variación neta da superficie por usos. Galicia, 1985-2005

\begin{tabular}{|l|c|c|c|c|}
\hline & 1985 & 2005 & \multicolumn{2}{|c|}{ Variación } \\
& ha & ha & ha & \% \\
\hline Superficie agraria & 927977 & 782074 & -145903 & $-15,7 \%$ \\
\hline Mato & 979178 & 777309 & -201869 & $-20,6 \%$ \\
\hline Terreo arborado: frondosas & 150919 & 269151 & 118232 & $+78,3 \%$ \\
\hline Terreo arborado: produtor & 833953 & 985146 & 151193 & $+18,1 \%$ \\
\hline Improdutivo & 67566 & 145913 & 78347 & $+116,0 \%$ \\
\hline
\end{tabular}

Fonte: Corbelle e Crecente (2014) 
O resultado é o panorama que encontramos na actualidade (cadro 4):

- Dos case tres millóns de hectáreas que forman o territorio de Galicia, a superficie agraria utilizada (SAU) -cultivos e pastos- limítase, segundo a Enquisa sobre a estrutura das explotacións agrarias de 2016, a 621600 ha, o $21 \%$ do territorio, moi por debaixo tanto da media da UE-28 (40 \%) como da española (46\%). Esa cifra varía tomando outras fontes, en función sobre todo da delimitación máis ou menos ampla dos pastos. Así, as estatísticas sobre usos do solo da Xunta de Galicia elevan a SAU a 874000 ha, o 29,5\% do territorio, computando aquí un 6,2 \% que corresponde a pastos extensivos fronteirizos co monte (cadro 4). En calquera caso, considerando as diversas fontes, a SAU oscila entre o $21 \%$ e o $30 \%$ do territorio, porcentaxe moi baixa no contexto español e europeo.

- A superficie arborada ocupa, segundo os datos que tomemos, entre 1,1 e 1,4 millóns de hectáreas ${ }^{2}$, ao redor do $40 \%$ do territorio. Pero tan só unhas 300000 ha, no mellor dos casos, están ordenadas e son obxecto dunha xestión silvícola, mentres que a maioría das terras arboradas non reciben ningún coidado e boa parte se atopan practicamente nunha situación de abandono.

- As «outras superficies», que inclúen augas interiores, terras improdutivas e as ocupadas por infraestruturas e usos urbanos, supoñen o $11 \%$.

- Finalmente, quedan un mínimo de 600000 ha, o $21 \%$ do territorio, ocupadas polo mato. Superficies que non son obxecto hoxe de ningún coidado nin aproveitamento económico, polo que cabe asimilalas a terras completa ou case completamente abandonadas.

O problema pode resumirse en que o espazo agrario está constrinxido a un cuarto ou un quinto do territorio, mentres que a metade corresponde a mato e a monte arborado sen unha adecuada xestión silvícola. Esta situación está moi distante dos usos potenciais que permitirían as aptitudes dos solos (Díaz-Fierros e Gil Sotres 1982). Especialmente nun punto: a SAU (do $21 \%$ ao $30 \%$ do territorio) está moi por debaixo do $50 \%$ que podería ser dedicado a cultivos e pastos, ao ser apto para o cultivo continuado ou ocasional; unha diferenza que se corresponde aproximadamente co volume de terras ocupadas polo mato (cadro 4).

\footnotetext{
2 Os datos da Xunta de Galicia recollidos no cadro 4 indican 1155300 ha, mentres que o Cuarto Inventario Forestal Nacional (IFN4) eleva a cifra a 1424094 ha.
} 
Cadro 4. Usos actuais da terra en Galicia; comparación cos usos potenciais

\begin{tabular}{|l|c|r|l|r|}
\hline Usos actuais (2011) & \multicolumn{2}{|c|}{ Miles de ha } & $\%$ & \multicolumn{2}{|c|}{ Capacidade de uso } & \% \\
\hline Superficie cultivada & 388,3 & 13,1 & Cultivo continuado & 34,7 \\
\hline $\begin{array}{l}\text { Prados e pasteiros } \\
\text { (Dese total, pasteiros } e \\
\text { pasteiros arbustivos) }\end{array}$ & 485,7 & 16,4 & Cultivo ocasional & 15,7 \\
\hline Mato & 182,3 & 6,2 & & \\
\hline Terreo arborado & 607,8 & 20,5 & & \\
\hline Outras superficies & 1155,3 & 39,1 & Non cultivable & 36,1 \\
\hline Total & 320,6 & 10,8 & Improdutivo ou baixo uso & 13,5 \\
\hline
\end{tabular}

Fonte: Elaboración propia a partir de datos da Consellería do Medio Rural e de Díaz-Fierros e Gil Sotres (1982)

Os datos globais esconden, tamén neste caso, enormes contrastes dentro da xeografía galega, contrastes que poden resumirse de novo na configuración de «tres Galicias rurais». Tomando a tipoloxía a nivel parroquial elaborada por Corbelle e Crecente (2014), esas tres Galicias rurais (en canto aos usos do solo) están constituídas por: 1) o «rural urbanizado e forestado», característico do Eixo Atlántico e da franxa costeira; 2) o «rural activo», integrado polas áreas -principalmente do interior da Coruña e Lugo- que presentan unha expansión recente e un elevado peso das terras agrarias, e 3) o «rural abandonado», definido polo forte peso das superficies de mato, que ocupa as serras orientais de Lugo, a dorsal galega e a maior parte da provincia de Ourense (mapa 3).

\subsection{Problema adicional: expansión e desorde da interface urbano-forestal}

Dentro da problemática xeral dos usos do solo, merece unha mención específica, pola súa relación cos incendios forestais, a cuestión da interface urbano-forestal. A ausencia dunha ordenación territorial favoreceu nas últimas décadas dous fenómenos que contribuíron a aumentar a vulnerabilidade fronte aos incendios. Por unha banda, a forestación de terras agrarias, moitas veces na contorna inmediata dos núcleos de poboación, e, simultaneamente, a construción desordenada de vivendas e instalacións empresariais, con frecuencia no medio ou nas proximidades de terreos forestais. Deste modo, as árbores e o mato foron avanzando cara aos núcleos de poboación (na maioría das áreas rurais), ao tempo que as 
Mapa 3. Tipoloxía das parroquias segundo as tendencias dos usos do solo (1985-2005)

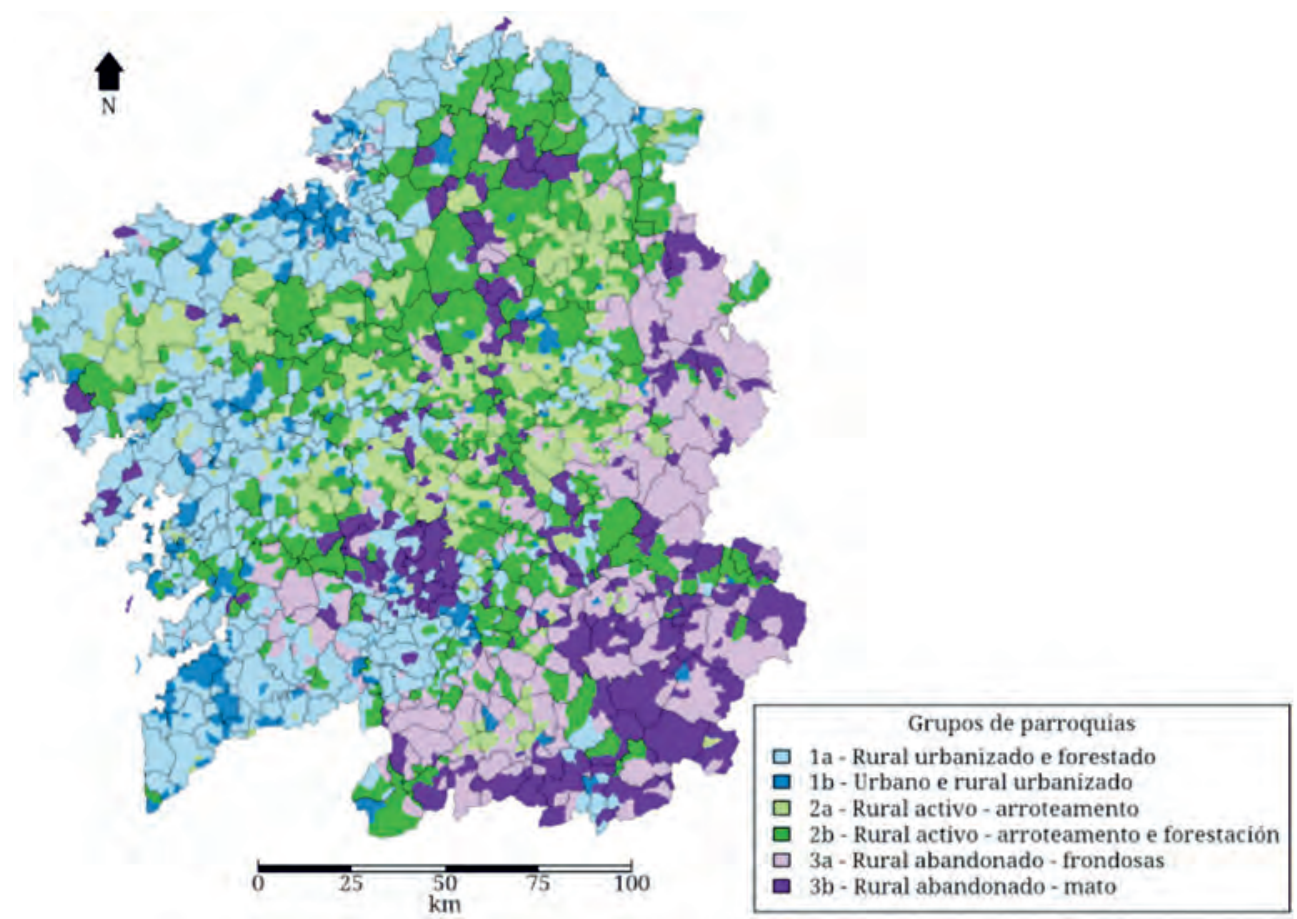

Fonte: Corbelle e Crecente (2014)

vivendas e as instalacións empresariais avanzaban cara ao monte (especialmente nas zonas periurbanas).

O resultado foi a configuración dunha interface urbano-forestal cada vez máis extensa e con maior acumulación de combustible. Así, segundo os cálculos realizados nun estudo recente (Chas, Touza e García 2013), as áreas da interface urbano-forestal ocupan actualmente en Galicia 244187 ha, o 8,3 \% do territorio. Ademais, estas áreas representan o $62,4 \%$ da superficie edificada e nelas están o 69,7 \% das construcións, o que significa que a maioría da poboación vive neste tipo de espazos.

Se analizamos a porcentaxe que supón a área de interface urbano-forestal sobre a superficie a nivel parroquial, constátase que o problema afecta sobre todo 
ao «rural urbanizado e forestado». Pero, máis alá desas zonas periurbanas de alta densidade de poboación, trátase dun fenómeno estendido, con intensidades variables, pola maior parte do territorio, dada a dispersión da estrutura do hábitat (Chas, Touza e García 2013).

\subsection{Distribución da superficie afectada polos incendios; relación con eses factores estruturais}

A incidencia que eses factores estruturais (dinámica global das áreas rurais e, en concreto, dos usos do solo) teñen sobre os incendios vese corroborada se analizamos a distribución xeográfica da superficie queimada. No mapa 4 está representada a superficie afectada por incendios forestais a nivel municipal en España no decenio 2001-2010. Fixándonos no territorio galego, os datos mostran unhas pautas claras. Das tres Galicias rurais que diferenciamos, en función das características socioeconómicas e os usos do solo, o problema dos incendios vénse concentrando en dous tipos de zonas: o "rural urbanizado e forestado», áreas costeiras e periurbanas con altas densidades demográficas, hábitat disperso e predominio das superficies arboradas; e o «rural abandonado», áreas de montaña e do interior que sofren un despoboamento acentuado e nas que se constata unha maior presenza do mato.

No outro extremo, os municipios menos afectados polos incendios coinciden co que Corbelle e Crecente (2014) clasifican como «rural activo», as principais áreas gandeiras do centro e norte de Galicia, onde existe un maior uso agrario do territorio, e tamén coas comarcas do terzo setentrional nas que a produción forestal está máis asentada, zonas produtoras de eucalipto con masas relativamente ordenadas (mapa 4).

Somos conscientes de que nesa distribución xeográfica da superficie afectada polos incendios desempeñan un papel relevante os factores climáticos. Pero, recoñecendo iso, parece indiscutible a influencia das variables que estamos a comentar, relacionadas coa dinámica das áreas rurais e os usos do solo. Neste sentido, o diagnóstico sobre as causas dos incendios esixe partir de que estes responden a unha interacción complexa de factores diversos (clima, orografía, variables socioeconómicas, usos do solo etc.). 
Mapa 4. Superficie afectada por incendios forestais a nivel municipal. España, 2001-2010

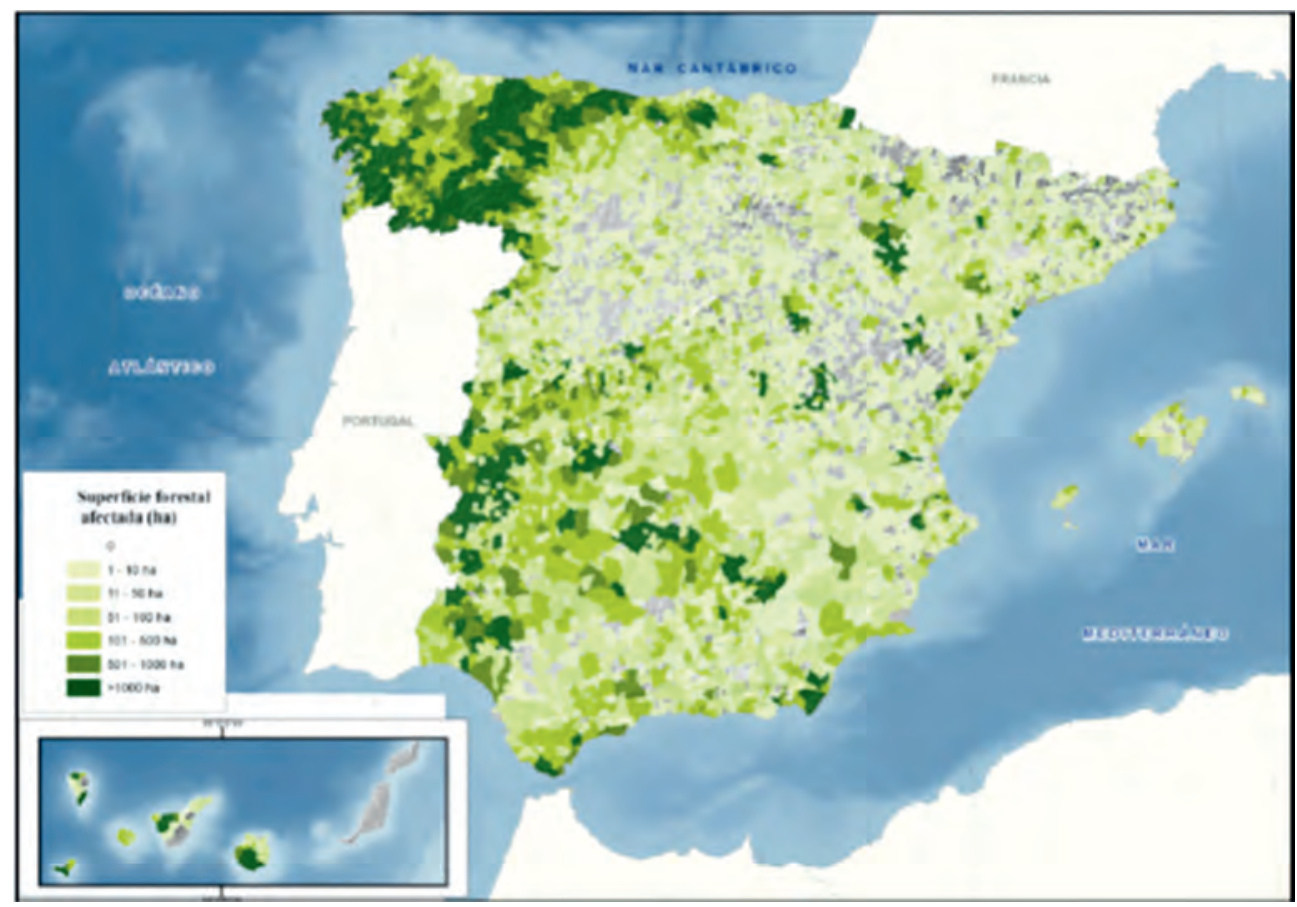

Fonte: MAGRAMA (2012): Los Incendios Forestales en España. Decenio 2001-2010

\section{ORIENTACIÓNS PARA CONFIGURAR UNS ESPAZOS RURAIS MENOS VULNERABLES FRONTE AOS INCENDIOS}

Da análise anterior cabe extraer algunhas orientacións para o futuro. A este respecto, é necesario diferenciar o urxente do importante a medio e longo prazo.

\subsection{O urxente: avanzar na prevención estrutural}

Para abordar o problema dos incendios, e atenuar os seus efectos, o máis urxente é avanzar na aplicación das medidas de prevención estrutural, especialmente as referidas á xestión da vexetación nas franxas de protección de vivendas e núcleos de poboación, instalacións empresariais e vías de comunicación. Unhas 
medidas establecidas na normativa desde a Lei 3/2007 de prevención e defensa contra os incendios forestais de Galicia, pero que tiveron até agora un incumprimento xeneralizado.

Neste punto, as disposicións para impulsar o cumprimento desas medidas que foron aprobadas a finais de 2017, na Lei 9/2017, do 26 de decembro, de medidas fiscais e administrativas, e outras actuacións adoptadas nos anos recentes pensamos que van, en xeral, na boa dirección e veñen a rectificar a pasividade neste aspecto da Xunta de Galicia desde 2009. Queda pendente, no entanto, o fundamental: a aplicación desas disposicións nos próximos anos.

Esta cuestión é esencial para evitar que moitos incendios se convertan, de forma case inmediata, nun problema de protección civil, no que a prioridade pasa a ser a defensa das persoas e das casas, de tal modo que os servizos de extinción poidan centrarse en controlar os incendios nos terreos forestais.

Porén, sobre a aplicación e eficacia desas accións de prevención estrutural convén facer varias precisións:

a) Para ser efectiva, a prevención debe estar estreitamente ligada á extinción. Isto posibilitará unha mellor planificación das accións de prevención, en función das necesidades do combate contra os incendios. De maneira recíproca, o coñecemento das accións de prevención realizadas é esencial para planificar a extinción. En consecuencia, o desexable é a integración da prevención e a extinción nun único dispositivo. A poder ser, que quen realice labores de prevención participe na extinción e viceversa.

b) O control da vexetación nas franxas de protección a través da roza supón un custo elevado para os propietarios e entidades que teñen esa obriga, custo que debe ser repetido de forma recorrente sen ningún retorno económico. No caso dos propietarios de terras adxacentes a vivendas, trátase ademais dun investimento para protexer o patrimonio de terceiros. Polo tanto, estas accións de roza serven como solución de urxencia, pero é necesaria unha reflexión sobre como distribuír os custos.

c) Se se pretende avanzar nunha alternativa sustentable (económica e socialmente), o desexable é fomentar nesas franxas usos da terra que eviten a acumulación de combustible e xeren ao mesmo tempo ingresos para os propietarios ou usuarios das superficies (cultivos e pastos, árbores para a produción de froitos...). 
d) Os estudos poñen de manifesto que en incendios de grande intensidade a eficacia das franxas de protección é moi limitada, posto que se producen proxeccións do lume a centenas de metros, mesmo a varios quilómetros (Comissão Técnica Independente 2018). Disto derívase unha lección importante: o esencial é a paisaxe e a ocupación do solo que configuremos, non só no contorno dos núcleos de poboación ou instalacións empresariais, senón no conxunto do territorio.

Polo tanto, máis alá desas medidas de prevención, o relevante a medio e longo prazo é avanzar nunha mellora da ordenación e xestión das superficies de monte, e globalmente do territorio. A configuración duns espazos rurais menos vulnerables aos incendios vai requirir, sobre todo se temos en conta os efectos do cambio climático, modificacións profundas nos usos do solo e na xestión do territorio. Modificacións que deben enmarcarse nun obxectivo máis xeral: configurar un novo rural, un «rural posible», adaptado á Galicia do século XXI (López Iglesias e Pérez Fra 2017).

\subsection{O importante: (re)construír un uso diversificado do monte, que responda ás demandas da sociedade}

Para contribuír a ese novo rural é preciso (re)construír un uso multifuncional das terras de monte, non como o que había no sistema agrario tradicional, senón adaptado ás condicións e demandas actuais da sociedade. Nese aproveitamento multifuncional han de ter cabida usos moi diversos: obtención de madeira a partir de especies de crecemento rápido, produción de madeiras de calidade, gandaría extensiva, pequenos froitos, aproveitamento da biomasa e outras fontes de enerxía renovable, funcións ambientais, fins recreativos e como espazo de lecer. Todos eses usos son compatibles, pero cunha adecuada ordenación.

Deses diferentes usos, os que implican a produción de bens e servizos para o mercado teñen que ser retribuídos polo mercado. Polo tanto, ben sexan os propietarios das terras ou outras persoas ou empresas, estes deben ser capaces de elaborar produtos en condicións adecuadas de calidade e prezo para o seu acceso aos mercados. Disto dependerá o futuro desas producións e dos usos da terra aos que están ligadas. Pero existen funcións (das superficies de monte e, en xeral, do medio rural) cada vez más demandadas (ambientais, socioterritoriais) que non 
remunera o mercado. En consecuencia, estas teñen que ser retribuídas polo conxunto da sociedade a través de transferencias públicas (pagos ambientais, pagos a superficies en zonas Natura 2000 e outros mecanismos) (Andrade e Vázquez 2016).

En calquera caso, cómpre ter claro un principio: todo o que pretendamos que produzan as terras ten que ser pagado por alguén e, polo tanto, ha de responder a unha demanda social real. Non serven os usos impostos aos propietarios sen unha adecuada retribución. Pero tampouco as alternativas puramente voluntaristas, que non contan con viabilidade económica nin responden a unha demanda social de certa entidade. En consecuencia, á hora de formular propostas sobre usos posibles das terras, a atención non pode centrarse só, como sucede con frecuencia, nos factores de oferta (que están en condicións de producir esas terras), senón que é imprescindible ter en conta, e avaliar de forma realista, a demanda para eses bens e servizos.

\subsection{A complexa relación entre dinámica socioeconómica das áreas rurais e usos do solo}

O desexable é que a mellora da ordenación e xestión da superficie se acompañe dunha revitalización demográfica e socioeconómica das áreas rurais e se apoie nela. Pero hai que ter claro que a relación entre ambos os procesos non é actualmente directa nin mecánica.

Até as décadas centrais do século XX existía en Galicia unha vinculación estreita entre poboación rural e espazo rural: os habitantes de cada parroquia, a inmensa maioría agricultores, tiñan a súa base económica no aproveitamento do espazo agroforestal circundante. Nos últimos decenios, porén, asistimos, igual que en toda Europa, a unha separación crecente entre poboación rural e espazo rural. Separación ou desvinculación que ten a orixe en dous fenómenos: a desagrarización da poboación rural e o forte incremento da súa mobilidade (a ruptura entre o lugar de residencia e o de traballo).

A consecuencia é que na actualidade non existe unha relación directa e simple entre despoboamento e abandono de terras, nin tampouco, en sentido contrario, entre dinamismo demográfico e adecuado aproveitamento das superficies. Isto reflíctese en realidades que podemos observar no rural galego: 
- Hoxe é posible encontrar exemplos dun espazo rural razoablemente xestionado, para usos agrogandeiros, forestais ou outras actividades, coexistindo cun acusado despoboamento. O que sucede nestes casos é que o aproveitamento das superficies é realizado principalmente por empresas ou persoas que non residen de modo continuado na zona.

- No extremo contrario atopamos, sobre todo nos ámbitos periurbanos, áreas rurais cun dinamismo demográfico importante á vez que un case completo abandono do espazo agrario e forestal. A explicación é que se trata de áreas convertidas en espazos residenciais ou cunha estrutura económica desvinculada da explotación da terra. De tal maneira que a inmensa maioría dos habitantes só residen na zona e desprázanse a traballar a núcleos urbanos próximos ou traballan en empresas locais pero noutras actividades.

Desa realidade, a complexa relación entre poboación rural e espazo rural, derívanse consecuencias importantes para os nosos efectos:

1. A revitalización demográfica e socioeconómica das áreas rurais non asegura por si mesma unha adecuada ordenación e xestión das terras; esa revitalización non constitúe unha condición suficiente. Isto é aplicable sobre todo aos espazos periurbanos, o que obriga a preguntarse polas fórmulas de xestión futura do territorio nestes espazos.

2. En sentido contrario, a revitalización demográfica e socioeconómica non é sempre condición necesaria, xa que a explotación das terras pode ser realizada por persoas ou empresas que non teñen a residencia habitual na zona. En relación con isto, debemos preguntarnos se nas comarcas cun despoboamento máis acusado non resulta inevitable asumir que a xestión das terras será realizada no futuro, polo menos en boa medida, por persoas ou empresas non residentes na zona; sendo complementadas esas actividades privadas pola xestión pública de amplos espazos naturais protexidos. Admitindo que isto non constitúe un horizonte ideal, a cuestión é que alternativas, viables, existen para a xestión do territorio nestas zonas.

3. A primeira das consideracións anteriores afecta sobre todo ás áreas periurbanas, ao «rural urbanizado e forestado», mentres que a segunda se refire principalmente ás zonas de montaña do «rural abandonado». De forma xeral, para todo tipo de comarcas, a ordenación e a mobilización produti- 
va das superficies van esixir conciliar os intereses de tres colectivos, que até mediados do século XX podían case asimilarse pero que cada vez coinciden menos: os residentes na zona, os propietarios das terras e as persoas ou empresas interesadas no seu aproveitamento.

\section{CONDICIONANTES DERIVADOS DA ESTRUTURA DA PROPIE- DADE DA TERRA}

Un elemento esencial que condiciona a xestión das superficies no medio rural galego é a estrutura da propiedade, unida ao mantemento dun cadro institucional sobre os dereitos asociados á propiedade da terra que é cada vez máis disfuncional.

Segundo o Catastro de Rústica, a superficie rural de Galicia (2,85 millóns de hectáreas) está dividida entre 1,67 millóns de propietarios (a nosa comunidade ten 2,71 millóns de habitantes) e 11,4 millóns de parcelas, de tal modo que a superficie media por propietario se limita a 1,7 ha, fragmentada en sete predios diferentes cunha extensión media de 0,25 ha.

Eses datos esconden, porén, realidades moi distintas. Centrándonos nas terras de monte, é necesario distinguir tres tipos de superficies de características diferentes, que se enfrontan a problemas tamén diferentes para a súa xestión produtiva $^{3}$.

a) Superficies de monte particular integradas en explotacións agrarias: $8 \%$ do territorio, unhas 240000 ha.

Estas superficies, pertencentes na súa maioría a agricultores e as súas familias, están divididas entre miles de propietarios. Ademais, excepto nas zonas onde se concluíu a concentración parcelaria e esta incluíu o monte, manteñen unha elevada fragmentación e deficiencias no acceso aos predios, elementos todos que dificultan un adecuado aproveitamento.

\footnotetext{
3 As cifras para cada un dos tipos de superficies son cálculos propios baseados no cruzamento de tres fontes: Enquisa sobre a estrutura das explotacións agrarias de 2016, o Cuarto Inventario Forestal Nacional (IFN4) e o Rexistro dos montes veciñais en man común da Consellería do Medio Rural.
} 
Fronte a eses problemas, estas terras presentan unha vantaxe: a súa xestión (para usos forestais, agrogandeiros ou outras producións) pode ser realizada por agricultores en activo.

b) Superficies de monte particular pertencentes a propietarios non agricultores: $39 \%$ do territorio, ao redor de 1150000 ha.

Estas terras presentan dous grandes obstáculos para unha adecuada ordenación e explotación. Por unha banda, sofren unha división da propiedade similar á dos terreos de cultivos e pastos, ou máis acusada: repartidas entre centos de miles de propietarios, cunha moi pequena superficie por propietario, caracterízanse ademais por unha forte fragmentación parcelaria e problemas de acceso aos predios. A iso únese que a inmensa maioría dos propietarios están desvinculados da xestión das superficies, mentres que é moi pequeno o colectivo do que podemos considerar como silvicultores profesionais.

Eses condicionantes teñen dous efectos. En primeiro lugar, provocan unha enorme dificultade para constituír unidades de produción viables, xa que isto esixe integrar as terras dun elevado número de propietarios. Ao que se engade a debilidade da iniciativa empresarial dos silvicultores profesionais, que deberían mobilizar as terras para a produción forestal (en explotacións individuais ou promovendo fórmulas de xestión colectiva).

c) Montes veciñais en man común (MVMC): terras de propiedade privada colectiva pertencentes a unhas 3000 comunidades, que suman 663500 hectáreas (23\% do territorio).

Ao contrario dos dous grupos anteriores, estamos aquí ante unidades, en xeral, de elevado tamaño e sen problemas de fragmentación parcelaria. Segundo os datos da Consellería do Medio Rural, a superficie media dos 3326 MVMC contabilizados en 2019 (pertencentes a 2992 comunidades) ascendía a 219,5 ha (Consellería do Medio Rural 2020). Pero estes espazos enfróntanse a outros condicionantes, que contribúen a un elevado abandono ou subutilización. Entre eles cabe mencionar os seguintes: a regresión e débil estrutura demográfica da maioría das comunidades propietarias, a escasa vinculación da maior parte dos comuneiros coa explotación do monte (dada a desagrarización do medio rural) e a inadecuación do marco legal e as políticas públicas nas décadas recentes (Grupo de Estudos da Propiedade Comunal 2006). 
Os distintos tipos de terras de monte que acabamos de citar son de propiedade privada: propiedade individual ou societaria nos montes particulares, propiedade privada colectiva nos MVMC. Neste sentido, como se destaca habitualmente, a superficie forestal de propiedade pública é en Galicia case insignificante (limítase ao $2 \%$ ). Pero debemos resaltar que non sucede o mesmo para a superficie de xestión pública. A Xunta de Galicia, a través dos servizos forestais, xestiona directamente unhas 290000 ha, preto do $15 \%$ da superficie forestal; unha importante capacidade de intervención que corresponde na súa maioría a terreos pertencentes a comunidades de MVMC xestionados pola Administración, a través de convenios ou antigos consorcios (cadro 5).

Cadro 5. Superficie forestal de xestión pública. Galicia, 2019

\begin{tabular}{|l|r|}
\hline & Hectáreas \\
\hline - Montes de Utilidade Pública & 22025 \\
\hline - Montes patrimoniais da Comunidade Autónoma & 12058 \\
\hline - Montes patrimoniais de concellos e ELM & 6849 \\
\hline Propiedade pública & $\mathbf{4 0 9 3 2}$ \\
\hline - Montes particulares & 14422 \\
\hline - Monte abertal, de varas, voces, fabeo & 1943 \\
\hline - MVMC & 233009 \\
\hline Propiedade privada & $\mathbf{2 4 9} 374$ \\
\hline Total xestión pública & $\mathbf{2 9 0 3 0 6}$ \\
\hline
\end{tabular}

Fonte: Consellería do Medio Rural, Anuario de Estatística Forestal de Galicia 2019

\section{A MODO DE CONCLUSIÓN: ALGUNHAS DIRECTRICES PARA AS POLÍTICAS FUTURAS}

Dados os problemas que xera o modelo de xestión de terras vixente en Galicia, resulta imprescindible abordar unha reforma estrutural adaptada ás necesidades actuais do medio rural. Reforma non centrada na propiedade, senón nos usos; que, sen alterar a distribución da propiedade, impulse a mobilización produtiva e unha adecuada xestión das superficies. Esta reforma, necesaria tamén por 
outros motivos económicos e ambientais, constitúe unha condición para reducir o risco de incendios a medio e longo prazo.

Sen entrar nunha proposta detallada de medidas, destacamos catro elementos centrais que deben presidir esa reforma estrutural, a xeito de directrices transversais:

a) Unha ordenación efectiva (non só no papel ou no $D O G$ ) dos usos do solo. Ordenación que delimite as terras urbanizables, as de vocación forestal -cunha ordenación por especies- e as reservadas para cultivos e pastos. E que regule tamén a localización doutras actividades económicas no medio rural, ademais de incorporar unha adecuada delimitación e mecanismos de apoio aos espazos naturais protexidos.

b) A configuración, na lexislación e nas políticas públicas, dun novo equilibrio entre propietarios e usuarios das terras. Un novo equilibrio que priorice os proxectos de aproveitamento (sempre que estean acordes coa ordenación de usos aprobada), fronte aos dereitos de propiedade daqueles que se limitan a manter as terras en estado de abandono ou de degradación produtiva e ambiental.

c) A coherencia dos incentivos das distintas políticas públicas coa ordenación de usos aprobada, corrixindo a fragmentación das políticas sectoriais e as contradicións entre elas que seguimos encontrando na actualidade.

d) Dado que a inmensa maioría do territorio rural de Galicia é de propiedade privada, a mellora do uso das terras debe ser protagonizada polos propietarios e pola iniciativa privada, e corresponderá ás institucións públicas establecer o marco regulador e os incentivos para que os intereses privados se aproximen o máis posible aos obxectivos colectivos. Pero iso deberá acompañarse dunha xestión pública directa, pola Xunta de Galicia, de determinadas superficies, como os MVMC abandonados para os que non existan outras alternativas ou certos espazos naturais protexidos. 


\section{REFERENCIAS BIBLIOGRÁFICAS}

Andrade Calvo, José Manuel / María Xosé Vázquez Rodríguez (2016): Novas demandas para o rural galego, Documento 18/2016, [Ourense], Foro Económico de Galicia.

Chas Amil, María Luisa / Julia Touza / Eduardo D. García Martínez (2013): «Delimitación de la Interfaz Urbano-Forestal en Galicia: análisis del riesgo de incendio», 6. Congreso Forestal Español, Vitoria-Gasteiz, 10-14 de xuño de 2013.

Comissão TéCnica Independente - CTI (João Guerreiro, Carlos Fonseca, António Salgueiro, Paulo Fernandes, Edelmiro López Iglesias, Richard de Neufville, Frutuoso Mateus, Marc Castellnou Ribau, Joaquim Sande Silva, José Manuel do Vale Moura Ferreira Gomes, Francisco Castro Rego, Duarte Caldeira) (2018): Avaliação dos incêndios ocorridos entre 14 e 16 de outubro de 2017 em Portugal Continental. Relatório Final, Lisboa, Assembleia da República.

Consellería do Medio Rural (2020): Anuario de Estatística Forestal de Galicia 2019, Santiago de Compostela, Xunta de Galicia. Consellería do Medio Rural.

CORbelle Rico, Eduardo / Rafael CReCENTE MASEDA (2014): «Urbanización, forestación e abandono. Cambios recentes na paisaxe de Galicia 1985-2005», Revista Galega de Economía, 23:1, 35-52.

Díaz-Fierros, Francisco / Fernando Gil Sotres (1982): «Evaluación da capacidade produtiva das terras de Galicia», Revista Galega de Estudios Agrarios, 7-8, 149-172.

FERnÁNDEZ, Melchor / David PEÓn (2017): Desafíos dunha sociedade avellentada e en declive: desequilibrios territoriais e prestación de servizos, Documento 20/2017, [Ourense], Foro Económico de Galicia.

Grupo de Estudos da Propiedade Comunal (Xaquín Fernández Leiceaga, Edelmiro López Iglesias, Manuel Jordán Rodríguez, Begoña Besteiro Rodríguez, Pablo Viso Outeiriño, Xesús Leopoldo Balboa López, Lourenzo Fernández Prieto, David Soto Fernández) (2006): Os montes veciñais en man común: o patrimonio silente. Natureza, economía, identidade e democracia na Galicia rural, Vigo, Xerais.

Instituto Galego de Estatística (2017): Panorama rural-urbano, Santiago de Compostela, Xunta de Galicia (https://www.ige.eu/web/mostrar_seccion.jsp?idioma=gl\&codigo=0701).

Instituto Galego da Vivenda e Solo (2008): Plan Sectorial Galego de Solo Residencial. Anexo II.1. Delimitación das áreas funcionais, Santiago de Compostela, Xunta de Galicia.

LÓPEZ IGLESIAS, Edelmiro (1996): Movilidad de la tierra y dinámica de las estructuras agrarias en Galicia, Madrid, Ministerio de Agricultura, Pesca y Alimentación, Secretaría General Técnica.

LÓPEZ IGLESIAS, Edelmiro (2000): «A dinámica recente e futura da poboación ocupada no sector agrario», en Xaquín Fernández Leiceaga (coord.), Avellentamento demográfico e consecuencias socioeconómicas, Vigo, Xerais, 141-179.

LÓPEZ IGLESIAS, Edelmiro (2019): «O sector agrario e agroalimentario en Galicia; balance das transformacións desde a integración europea (1986-2016)», Revista Galega de Economía, 28:3, 1-20.

López Iglesias, Edelmiro / Mar Pérez Fra (2004): «Axuste agrario e despoboación rural: as tendencias recentes en Galicia», Grial. Revista Galega de Cultura, 162, 36-43.

LÓPEZ Iglesias, Edelmiro / Mar PÉREZ Fra (2017): Unha estratexia para a Galicia rural do século XXI: diagnóstico e propostas para o debate, Documento 22/2017, [Ourense], Foro Económico de Galicia.

López Iglesias, Edelmiro / Francisco Sineiro García / Roberto Lorenzana Fernández (2013): «Processes of farmland abandonment: land use change and structural adjustment in Galicia (Spain)», en Dionisio Ortiz-Miranda / Ana Moragues-Faus / Eladio Arnalte-Alegre (eds.), Agriculture in Mediterranean Europe: between Old and New Paradigms, Bingley, Emerald Group Publishing, 91-120. 
Oliveira BAPTISTA, Fernando (2010): «A transição rural», en O espaço rural: declínio da agricultura, Oeiras, Celta, 137-175.

SineIro GarCía, Francisco (2006): «As causas estructurais dos incendios forestais en Galicia», en Francisco

Díaz-Fierros / Plácido Baamonde (coords.), Os incendios forestais en Galicia, Santiago de Compostela, Consello da Cultura Galega, 77-99. 


\title{
ORDE E DESORDE NO ESPAZO FORESTAL
}

\author{
Juan Picos Martín
}

Escola de Enxeñaría Forestal de Pontevedra Universidade de Vigo 



\section{UNHA NOVA XERACIÓN DE LUMES (?)}

A evolución do réxime de incendios está a xerar episodios que difiren en duración, intensidade e período de retorno do que viñemos considerando normal con referencia aos anos 60, 70, 80 e 90 do século XX.

Segundo a clasificación dinámica de xeracións de incendios reflectida na táboa 1, a nivel global existe unha tendencia á aparición de graves episodios de incendios en escalas cada vez maiores.

Táboa 1. Descrición das xeracións de incendios segundo Castellnou

\begin{tabular}{|c|c|c|}
\hline $1^{a}$ xeración & Continuidade (C) & $\begin{array}{l}\text { A paisaxe rural descontinua empeza a abandonarse. A continuidade } \\
\text { de combustible permite ás chamas crear incendios grandes. }\end{array}$ \\
\hline $2^{a}$ xeración & $\mathrm{C}+$ velocidade $(\mathrm{V})$ & $\begin{array}{l}\text { Esta paisaxe segue sen xestión e a acumulación de combustible } \\
\text { permite un aumento da velocidade de propagación das frontes. }\end{array}$ \\
\hline $3^{a}$ xeración & $\mathrm{C}+\mathrm{V}+$ intensidade $(\mathrm{I})$ & $\begin{array}{l}\text { O paso do tempo segue engadindo carga de combustible. } \\
\text { As frontes son máis intensas e permiten xerar incendios convectivos, } \\
\text { con ambiente de lume e focos secundarios masivos. O ataque directo } \\
\text { falla xa nestas situacións, como falla tamén a prevención clásica } \\
\text { de devasa ou cortalumes. }\end{array}$ \\
\hline $4^{a}$ xeración & $\begin{array}{l}\mathrm{C}+\mathrm{V}+\mathrm{I}+ \\
\text { Grandes Incendios } \\
\text { Forestais na interface } \\
(\mathrm{IF})\end{array}$ & $\begin{array}{l}\text { Os incendios propáganse na interface urbano-forestal. O problema xa } \\
\text { non é un problema forestal, é unha emerxencia de protección civil. } \\
\text { As prioridades veñen dominadas pola defensa. Pérdese a iniciativa. } \\
\text { Risco de colapso do sistema de resposta a emerxencias. }\end{array}$ \\
\hline $5^{a}$ xeración & $\begin{array}{l}\mathrm{C}+\mathrm{V}+\mathrm{I}+\mathrm{IF}+ \\
\text { simultaneidade de GIF } \\
(\mathrm{S})\end{array}$ & $\begin{array}{l}\text { Episodios de simultaneidade de incendios de } 3^{a} \text { ou } 4^{a} \text { xeración } \\
\text { cando se dan condicións estruturais de seca sobre as que se solapa } \\
\text { unha conxuntura meteorolóxica extrema. Colapso do sistema local e } \\
\text { rexional de resposta a emerxencias. A cooperación interaxencia ou } \\
\text { interrexional é unha necesidade. }\end{array}$ \\
\hline $6^{a}$ xeración & $\begin{array}{l}\mathrm{C}+\mathrm{V}+\mathrm{I}+\mathrm{IF}+\mathrm{S}+ \\
\text { cambio climático }(\mathrm{CC})\end{array}$ & $\begin{array}{l}\text { Situación de tormentas de lume. O cambio climático xera áreas } \\
\text { forestais sometidas a un enorme estrés e dispoñibles para queimar. } \\
\text { A intensidade liberada nestes casos permite ao incendio dominar as } \\
\text { condicións meteorolóxicas da súa contorna, co cal crea condicións } \\
\text { de tormenta e propagacións extremas. }\end{array}$ \\
\hline
\end{tabular}

Fonte: Castellnou e Miralles (2008), Picos et al. (2018) 
$\mathrm{Na}$ actualidade, o patrón de incendios implica lumes que presentan continuidade e velocidade en zonas até agora esencialmente rurais e que comezan a incrementar a súa intensidade, a súa capacidade convectiva e a emisión de focos secundarios, aspecto de especial gravidade en áreas de poboamento disperso. Este patrón está evolucionando con rapidez cara a situacións de grandes incendios con afección múltiple na interface urbano-forestal. Isto erosiona a capacidade de resposta do operativo contra incendios, que ten que adoptar estratexias defensivas, coa nefasta consecuencia que iso implica: deixar de atacar no espazo forestal. Esta circunstancia determinouse como relevante e crítica nas distintas análises dos episodios de incendios sufridos en 2017 tanto en Portugal como en Galicia.

Esta evolución do patrón de incendios forestais ten a súa raíz na xestión da paisaxe, na escalada na continuidade e carga de combustible propiciada polo abandono das actividades rurais, principalmente agricultura, gandaría e xestión forestal. Con todo, o cambio climático súmase, a maiores, ao favorecer unhas tempadas de risco máis longas, uns períodos de seca máis prolongados e unha maior e máis rápida acumulación e posta en dispoñibilidade do combustible.

Esta complexa realidade dos incendios no oeste peninsular é a que máis se está agravando nos últimos anos. De feito, dos grandes incendios de máis de 10000 ha nos pasados 15 anos na Península Ibérica, máis do 80 \% déronse nesta zona xeográfica (táboa 2).

Ademais, o denominado "paradoxo da extinción» (Castellnou e Rifa 2007) formúlase como un proceso mediante o que a crecente presión de extinción implica unha proporción cada vez maior de conatos, pola rápida intervención, pero aqueles que non son controlados queiman grandes superficies con intensidades cada vez superiores. Isto quere dicir que, cantos máis medios e máis presión aplicamos sobre o lume, mellor se controlan os incendios, pero a acumulación de biomasa e a súa continuidade comportan que os poucos que escapan a este control se fagan máis grandes e destrutivos e baseen a súa evolución nunha crecente carga de combustible.

É precisamente nas zonas de invernos húmidos e temperados onde o cambio climático está a sumar máis puntos na evolución do problema, en esencia porque é onde se acumula de maneira máis rápida e constante a carga de combustible e, durante situacións de aridez extrema longas, entra en dispoñibilidade. 
Táboa 2. Incendios de máis de 10000 ha na Península Ibérica nos últimos 15 anos

\begin{tabular}{|c|c|c|c|}
\hline Incendio & Ano & Superficie (ha) & Área xeográfica \\
\hline Várzea dos Cavaleiros & 2017 & 33693 & Oeste peninsular \\
\hline Pedrógão Grande & 2017 & 28913 & Oeste peninsular \\
\hline Cortes de Pallás & 2012 & 28079 & Levante \\
\hline Minas de Riotinto & 2004 & 28065 & Oeste peninsular \\
\hline Monchique & 2018 & 26763 & Suroeste peninsular \\
\hline Cachopo & 2012 & 24843 & Oeste peninsular \\
\hline Ulme & 2003 & 22190 & Oeste peninsular \\
\hline Janarde & 2016 & 21909 & Oeste peninsular \\
\hline Belver & 2003 & 20087 & Oeste peninsular \\
\hline Andilla & 2012 & 20025 & Levante \\
\hline San Matías & 2003 & 17869 & Oeste peninsular \\
\hline Álvares & 2017 & 17520 & Oeste peninsular \\
\hline Alferce & 2003 & 17213 & Oeste peninsular \\
\hline Alte & 2004 & 14508 & Oeste peninsular \\
\hline Ferradosa & 2013 & 14136 & Oeste peninsular \\
\hline Sobreira Formosa & 2003 & 13500 & Oeste peninsular \\
\hline Cáceres & 2003 & 13450 & Oeste peninsular \\
\hline Marmelete & 2003 & 13144 & Oeste peninsular \\
\hline Riba de Saelices & 2005 & 12732 & Sistema Ibérico \\
\hline Silves & 2003 & 12656 & Oeste peninsular \\
\hline Castrocontrigo & 2012 & 11950 & Oeste peninsular \\
\hline Vidual & 2005 & 11706 & Oeste peninsular \\
\hline Isna & 2003 & 11300 & Oeste peninsular \\
\hline La Jonquera & 2012 & 10578 & Levante \\
\hline Ermida & 2003 & 10500 & Oeste peninsular \\
\hline Encinedo & 2017 & 10315 & Oeste peninsular \\
\hline Robledano & 2005 & 10021 & Oeste peninsular \\
\hline Complexo Verín-Viana-A Limia & 2005 & 14486 & Oeste peninsular \\
\hline Complexo Galicia costa 2006 & 2006 & $>70000$ & Oeste peninsular \\
\hline Complexo Pontevedra 2017 & 2017 & $>20000$ & Oeste peninsular \\
\hline
\end{tabular}

Fonte: Elaboración propia a partir de MAPAMA, Fernandes et al. (2016) e Picos et al. (2018) 
O principal risco futuro consiste en que se sufra no oeste e noroeste peninsulares a mesma evolución do comportamento dos incendios vivida entre 1994 e 2009 no leste da Península. Isto significaría pasar estruturalmente de episodios de incendios simultáneos de primeira e segunda xeración a episodios de quinta xeración. Existen indicios desta tendencia que viñeron sendo constatados polos servizos de defensa contra incendios forestais durante os últimos quince anos. Ademais, non se debe ignorar o feito de que en zonas interiores de Portugal e Galicia se teñan observado algúns episodios de incendios de terceira xeración. É aquí onde se atopa o potencial, materializado en 2017, dos incendios de sexta xeración. Como xa se dixo, é o primeiro lugar en Europa onde se evidencia este tipo de incendio, e é moi relevante que fose no atlántico peninsular húmido e non no mediterráneo seco. Isto apunta ao papel da rápida acumulación de combustible fino, até supor elevadas cargas, que eventualmente as condicións meteorolóxicas adversas fan dispoñibles. Este fenómeno non se dá, con esa intensidade, no mediterráneo máis árido.

\section{QUE FACER?}

\subsection{Aproximación á prevención}

O estudo dos grandes incendios do 2017, en especial os acontecidos en Portugal, conclúe a chegada da tipoloxía de incendios de sexta xeración. Estes caracterízanse, basicamente, por seren incendios que conseguen xerar grandes cantidades de enerxía e incrementos da velocidade de propagación en frontes extensas. Isto convérteos en incendios letais para a poboación, os servizos de defensa contra incendios, as infraestruturas e os intereses da sociedade en xeral.

$\mathrm{O}$ incendio forestal hai tempo que deixou de ser un problema exclusivo duns servizos de extinción que necesitan consumir cada vez máis recursos durante unha campaña cada vez máis longa. Os sucesivos incrementos orzamentarios e aumentos de medios e recursos anualmente na loita contra os incendios forestais non producen melloras significativas na redución da superficie queimada. Por outra banda, a efectividade dos medios de extinción está próxima ao seu límite e as posibilidades de continuar reducindo o impacto dos incendios forestais 
pasan inevitablemente pola mellora das estratexias preventivas eficientes que reduzan os riscos (Oliveira 2016).

Ademais de se efectuaren cambios nas estratexias de protección civil e nos dispositivos de defensa contra incendios, no que atinxe ás políticas sobre o territorio rural deberíase facer especial fincapé na xestión da carga de combustible. O obxectivo radica en evitar incendios de terceira xeración, situacións de incendios convectivos alleos á capacidade de extinción, e reducir, no posible, a súa evolución cara a episodios extremos de quinta e sexta xeración.

Cando un grande incendio forestal afecta áreas extensas que presentan unha alta carga de combustible procedente dun abandono da agricultura e a silvicultura, acaba homoxeneizando aínda máis o territorio. Se ao incendio lle sucede un maior abandono das actividades e a recuperación da vexetación volve incrementar a carga de combustible, o risco de sufrir outro grande incendio é maior.

Para anticiparse ás situacións de perturbación causadas polo lume, a acción silvícola é fundamental e, en xeral, terá sempre certa compoñente preventiva no seu obxectivo de xestión e mellora das masas forestais.

Pola contra, existe determinada corrente de opinión que preconiza a non-intervención nos procesos ecolóxicos, para deixar que a natureza actúe por si mesma. Con todo, parece máis razoable actuar previndo que os danos se produzan ou para que, no caso de ocorreren, a súa acción resulte minimizada e, mediante a persistencia e a multifuncionalidade, poidan satisfacerse as lexítimas demandas dos propietarios forestais e da sociedade.

\subsection{Os combustibles forestais}

O lume é unha reacción química de oxidación exotérmica, na cal se libera a enerxía contida nas ligazóns dos compostos orgánicos. Para que se produza o lume necesítanse os tres elementos que forman o chamado triángulo do lume: combustible, comburente (osíxeno) e calor (iniciadora do proceso de combustión e precisa para mantelo).

Os combustibles son calquera substancia ou composto susceptible de acenderse e manter un proceso de combustión. Nos ecosistemas terrestres o combustible adoitan ser os compostos orgánicos (principalmente celulosa e lignina) producidos na fotosíntese. Por tanto, cando se fala de combustibles forestais 
estase a considerar toda a materia orgánica que se atopa nos montes en condicións de dispoñibilidade para a combustión nun potencial incendio. Esta categoría comprende a biomasa de plantas vivas, a súa follaxe, os seus talos, as súas ramas e as súas raíces; a necromasa -restos de tecidos mortos-, que inclúe árbores mortas en pé ou caídas, cepos, outros restos leñosos e follas que se atopan na manta de descomposición sobre o chan, así como a materia orgánica que forma parte do solo.

O tipo de material combustible e as súas características físicas e químicas, a cantidade «carga» del, a súa superficie de exposición, o seu grao de compactidade e a súa distribución espacial nos planos horizontal e vertical son os factores que determinarán o comportamento do lume.

Os estudos de combustión de vexetación no laboratorio mostran que existen diferenzas no que se denomina «inflamabilidade» das plantas. Este concepto, que non ten unha definición científica estándar, basicamente se refire a un indicador da «facilidade de arder ante unha fonte de calor determinada», elaborado a partir da medición correspondente a unha mostra estandarizada de tempo para a ignición, a rapidez da combustión e a enerxía desprendida. Cos valores característicos para cada especie (ou parte característica de cada especie), adóitase efectuar a clasificación en máis ou menos inflamables.

Os diferentes estudos levados a cabo a escala de poboamento forestal e paisaxe veñen evidenciando que os estudos realizados a escala de planta ofrecen unha visión moi limitada do comportamento do lume nas condicións en que se desenvolve no monte.

Aínda que existen distintos traballos sobre a selectividade de tipos de usos, vexetación e utilización do solo polos incendios, as relacións atopadas non implican que a mera composición da masa forestal sexa o factor primordial e exclusivo da maior ou menor afección polos incendios forestais.

Os combustibles son complexos en moi alto grao nas súas características e interaccións. Normalmente, mesmo por riba da súa composición específica, a estrutura da masa é o principal condicionante da súa inflamabilidade a escala de poboamento forestal e paisaxe. Esa estrutura complexa clasifícase no que se denomina «modelos de combustible», que dependen tanto da especie como, sobre todo, da cantidade de biomasa dispoñible para o lume e da forma en que se organiza. 
A variación espacial do complexo de combustibles está asociada á da cuberta vexetal e é determinada pola influencia de factores como o clima, as características fisiográficas, os chans e as perturbacións pasadas, que deron lugar a un mosaico de vexetación que se atopa en distintas etapas de desenvolvemento.

O termo combustibilidade aplícase, en silvicultura preventiva e extinción de incendios forestais, para definir a facilidade coa que un incendio podería progresar nunha determinada masa forestal ao recibir calor por radiación ou convección, ou ambas. A combustibilidade das masas dependerá da humidade, tamaño, disposición e abundancia dos seus combustibles.

O contido de humidade varía temporalmente en relación cos cambios de sucesión e estación da vexetación e coa variación nas condicións meteorolóxicas. En ausencia de choiva, a humidade relativa do aire é o factor que máis inflúe na humidade dos combustibles mortos. Normalmente xeran maior risco os materiais mortos ou secos que os materiais vivos ou verdes. Os combustibles verdes teñen un contido de auga de arredor do $70 \%$ en peso cando non hai seca e, en condicións extremas, poden baixar a cifras de arredor do $30 \%$. Os combustibles secos ou mortos poden conter até un $50 \%$ de humidade en saturación pero chegar a secarse até valores próximos ao $3 \%$. Por baixo do $10 \%$ xa se considera que existe alto risco (Vélez 2000).

Os combustibles finos expoñen unha maior superficie específica, o que facilita a perda de humidade e, no momento do incendio, a oxidación, a combustión total e a liberación rápida de enerxía, que será a que sosteña o lume. Así, canto máis finos sexan os combustibles, será esperable unha maior velocidade de avance e propagación. Este é o caso dos herbais, as matogueiras, as ramiñas cubertas de agullas secas e as ramas finas do arboredo, máis abundantes preto do chan nas clases de idade novas e cando hai restos de talla ou tratamentos silvícolas. Son denominados combustibles rápidos porque teñen gran facilidade para cambiar a súa humidade (desecándose ou incorporándoa).

Os incendios comezan normalmente na superficie e propáganse pola continuidade horizontal do material combustible, avivados por outras condicións favorables como o vento ou a pendente. Se alcanza suficiente intensidade, a calor, transmitida fundamentalmente por convección e axudada polos chamados «combustibles de escaleira» (arbustos ou árbores pequenas e troncos de árbores mortas, así como brións, liques e plantas epífitas), provoca que as ramas inferiores e a follaxe das árbores entren en ignición. 
Estes incendios denomínanse incendios de copas e poden pola súa vez clasificarse en pasivos, activos e independentes do lume de superficie. Nun incendio de copas pasivo, as copas arden individualmente e non prospera a propagación do lume a través dos elementos finos do combustible no dosel. Por outra banda, no incendio de copas activo, o lume propágase de forma continua polo estrato aéreo, pero necesita para manterse, en todo momento, da calor xerada polo incendio de superficie. Por último, nun incendio de copas independente do lume de superficie, o lume de copas avanza de maneira independente empuxado polo vento e a maior velocidade que o de superficie, que queda atrasado. A existencia dos dous últimos tipos de incendios de copas require, ademais, velocidades de vento elevadas e dispoñibilidade de combustible dunha densidade aparente significativamente superior á densidade real.

$\mathrm{Na}$ evolución dun incendio de superficie a outro de copas activo, a velocidade de propagación do lume sofre un incremento súbito que chega a duplicar a velocidade de avance do lume superficial, o que pode significar que se multiplique por catro o tamaño da área queimada no mesmo período. Isto supón un problema engadido para as persoas involucradas na extinción, posto que os incendios de copas presentan un nivel de comportamento do lume que usualmente impide as accións de ataque directo e, no caso dos lumes de copas independentes, aumentan de forma radical os perigos de entalamento.

Por outra banda, a materia orgánica do chan polo xeral retén humidade por máis tempo e atópase en atmosferas de escasa achega de osíxeno, o cal fai que exista unha maior dificultade para que entre en ignición. Cando isto ocorre, xeralmente en solos moi ricos en materia orgánica, pode dar lugar a incendios subterráneos, que se propagan con lentitude, son moi difíciles de extinguir, xeran unha gran cantidade de calor e provocan unha alta gravidade ao cambiaren dun xeito significativo as características dos solos.

Despois de analizarmos todas estas características, definiremos «combustible dispoñible» ou «combustible dispoñible para arder» como aquel que, nun determinado momento, posúe un tamaño e unha humidade que permiten a combustión da biomasa ao verse afectada esta polas chamas ou a enerxía irradiada pola fronte do incendio.

A mellor maneira de comprobar que non toda a biomasa vexetal dun ecosistema terrestre é combustible dispoñible é observar que, tras o paso dun incendio, 
aínda que desaparece boa parte do sotobosque, a follada e a frouma do chan, así como as follas e ramiñas terminais dos piñeiros, hai unha fracción significativa que non se consome, como troncos, ramas grosas e unha parte das ramas finas.

\subsection{Principios da silvicultura preventiva}

Segundo Vélez (2000), a silvicultura preventiva é un conxunto de regras que se inclúen dentro da silvicultura xeral co propósito de conseguir estruturas de masa con menor grao de combustibilidade, é dicir, con maior resistencia á propagación do lume.

Os obxectivos da silvicultura preventiva de incendios son os seguintes:

- Diminuír o número total de sinistros, previndo ou evitando, na medida do posible, a ignición ou o inicio do lume.

- Impedir ou dificultar a propagación daqueles incendios cuxo inicio non se puido evitar.

- Minorar os danos, especialmente a superficie percorrida, no caso de que o incendio se produza.

- Facilitar os labores de extinción dos incendios que non foi posible evitar e darlles seguridade. Este obxectivo, o máis importante, cítase en último lugar por ser consecuencia dos dous anteriores.

Basicamente, a aplicación da silvicultura preventiva pódese realizar en dous niveis territoriais: así, diferéncianse estratexias a escala local (parcela, monte ou grupo de montes) e a escala comarcal.

Deixando á parte, por excederen o ámbito deste documento, a redución do número e risco de ignicións e as axudas á protección de bens e ao combate, as principais accións previstas pola silvicultura preventiva son as citadas a seguir:

- Actuacións sobre o combustible forestal.

- Creación de descontinuidades na masa e nas infraestruturas lineais.

- Prevención a escala comarcal. Modificación do combustible a escala de paisaxe.

Actuando sobre os combustibles búscase influír na intensidade do lume e na súa velocidade de propagación horizontal e vertical, aumentar a súa previsibilidade e, por conseguinte, diminuír a área queimada e aumentar a eficiencia e seguridade dos medios de extinción. Indirectamente, tamén se acaba diminuíndo a potencial gravidade do incendio e, por iso, o seu impacto ambiental. 
Os principios xerais da xestión dos combustibles e da silvicultura preventiva son coñecidos, con todo, pola elevada complexidade do comportamento e dos efectos dos incendios, especialmente en ambientes meteorolóxicos extremos; aínda existen incertezas e aínda é limitada a comprensión dos efectos que a dita xestión ten no comportamento do lume.

Segundo Pyne et al. (1996), as tres estratexias principais de acción sobre o combustible forestal na silvicultura preventiva son redución, conversión e illamento. Noutras palabras, buscaranse cambios na cantidade de combustible, na súa estrutura, na súa tipoloxía e na xeración de descontinuidades na masa que se quere protexer.

O cambio na tipoloxía de combustible -estratexia de conversión- consiste na substitución da vexetación existente por outra que reduza a magnitude das variables de comportamento do lume (velocidade de propagación, intensidade lineal da fronte de chamas etc.) ou limite a súa propagación.

Este efecto moderador é alegado con frecuencia, por exemplo, no caso das masas de frondosas caducifolias, a pesar de que, en moitas ocasións, máis que ser o mero froito das características intrínsecas destas especies, o efecto vén moito máis condicionado polo ambiente asociado habitualmente a este tipo de formacións, menos ventoso e máis fresco e húmido, en especial nos momentos de secas prolongadas.

Para influir sobre a cantidade e dispoñibilidade do combustible, deberanse reducir os combustibles de superficie (follada, frouma, restos leñosos e vexetación de matogueira viva), co fin de limitar a intensidade potencial do lume de superficie, facilitar o seu control por parte dos medios de extinción e dificultar o lume de copas.

A cantidade de combustible é denominada «carga de combustible» e adóitase medir en toneladas por hectárea; nela é habitual que se faga distinción das distintas fraccións do combustible.

Na ilustración 1 amósase un exemplo (adaptado de Fernandes [2009]) da relación entre a intensidade da fronte do incendio e a carga de combustible fino para as distintas situacións de perigo de incendio forestal (medido segundo o FFDI ou índice de McArthur). Indícanse, ademais, os límites de intensidade cos que é posible facer fronte ao incendio en función dos medios utilizados. Pódese apreciar que, para índices de perigo baixos, o límite en ataque directo ao 
lume (mesmo co uso de maquinaria e medios aéreos) non se supera con cargas de $30 \mathrm{t} / \mathrm{ha}$, pero que, en situacións de risco medio, alto e moi alto, estes valores límite son 28, 18 e 13 t/ha, respectivamente. Cando o perigo é extremo, bastan 8 t/ha de combustible fino para superar intensidades que están moi por riba da capacidade de extinción.

Esta é a razón pola que reducir as cantidades de combustible, en especial aquelas fraccións que ofrecen maior dispoñibilidade para arder, como son os combustibles finos e mortos, é imprescindible para abordar a prevención da propagación dos incendios dunha maneira efectiva.

Para alén de actuar na mera eliminación, resulta decisivo promover, mediante a aplicación das técnicas xerais da silvicultura, que a masa se atope nas mellores condicións de vigor e sanidade. Unha masa sa e vigorosa presenta, en proporción, unha menor cantidade de biomasa fina e morta.

Complementariamente, é moi importante proceder á eliminación ou tratamento dos restos producidos en operacións silvícolas e aproveitamentos. De preferencia, executarase ese proceso por trituración ou estelado porque o usual é que as achas queden depositadas no chan, ardan con gran dificultade e atrasen ademais a invasión do chan pola matogueira e as herbáceas (ilustración 1).

Ademais da conversión e a redución, é importantísimo acometer accións sobre a estrutura espacial do combustible. Dise que hai continuidade horizontal nun estrato de combustible cando non existen grandes espazos libres de combustible que impidan o avance do lume en ningunha dirección. A continuidade vertical implica a existencia dunha ponte entre os combustibles dos distintos estratos e, por tanto, favorece a transformación do lume de superficie en lume de copas.

As accións máis relevantes sobre a estrutura do combustible son as seguintes:

- Distanciar a base das copas do chan (principalmente mediante podas e clareos) e eliminar os combustibles de transición que establezan continuidades con aquelas, co fin de minimizar a posibilidade de desenvolvemento vertical de lume.

- Rarear a masa, normalmente polo baixo, para diminuír a densidade aparente da cuberta de copas e así dificultar a propagación do lume entre árbores contiguas.

- Conservar as árbores máis grandes da masa. As árbores de maiores dimensións adoitan ser máis resistentes ao lume, xa que habitualmente teñen as 
Ilustración 1. Relación entre intensidade da fronte do incendio, índices de perigo, carga de combustible e capacidades de extinción en masas de eucalipto

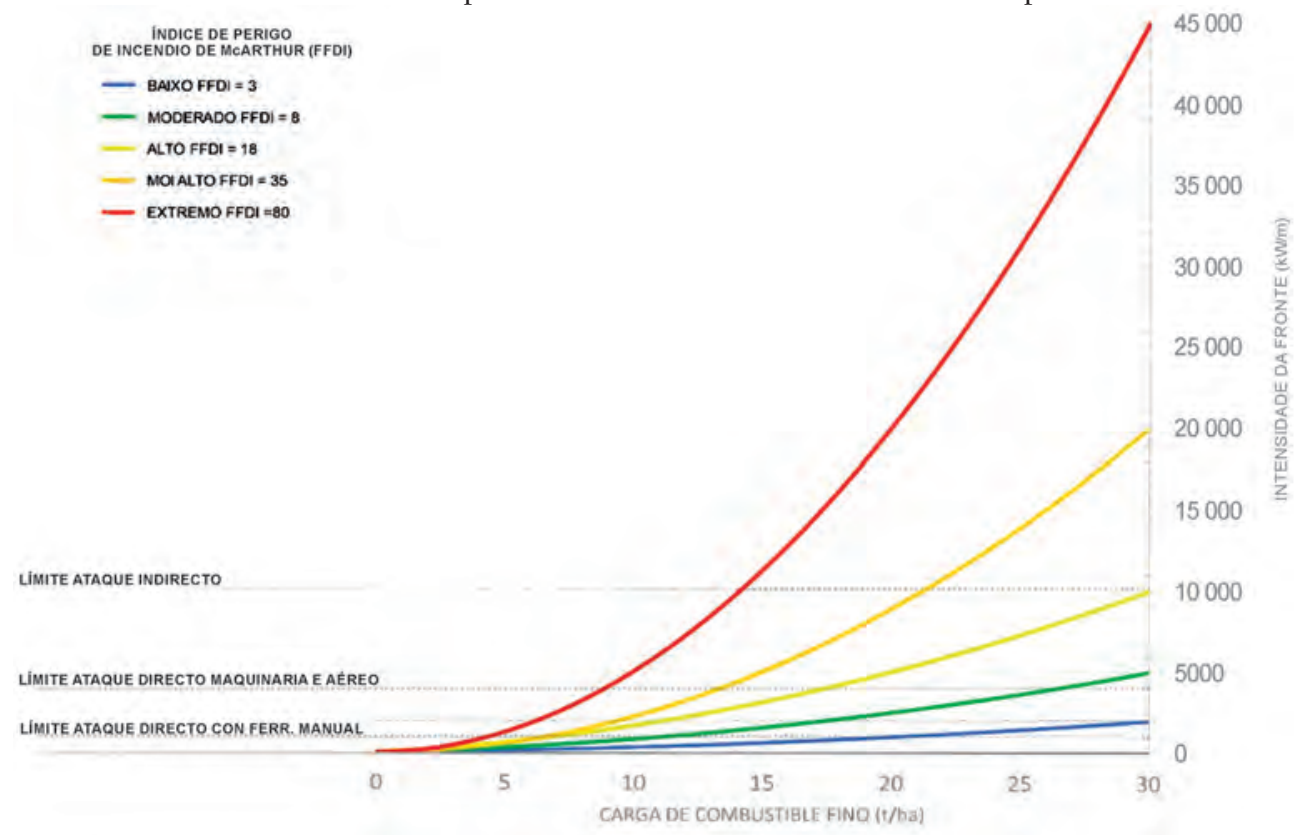

ADAPTADO DE FERNANDES (2009)

copas máis altas e a cortiza máis grosa. Así mesmo, poderían axudar á rexeneración natural da masa tras un incendio.

- O resultado das accións combinadas que acaban de citarse será independizar as copas do arboredo respecto do chan, acentuando a descontinuidade vertical, e modificar no monte a disposición do tipo de combustible de maior facilidade de ignición. A consecuencia será que, en caso de incendio, predomine o lume de superficie, de menor velocidade de avance, de maior facilidade e seguridade na extinción e de menor dano para o arboredo.

Outra das ferramentas de xestión preventiva é a creación de descontinuidades na masa. Esta estratexia do illamento consiste en romper a continuidade horizontal das masas forestais, eliminando ou reducindo a vexetación, para compartimentalas mediante faixas de anchura variable ou crear mosaicos. 
En xeral, pódese distinguir entre unha estratexia baseada en interrupcións ou tratamentos lineais en forma de faixas e devasas e unha estratexia que se basea en tratamentos en áreas máis extensas.

As devasas son espazos alongados, cunha anchura de entre 20 e 30 metros, nos que se elimina todo tipo de vexetación, deixando frecuentemente o chan mineral ao descuberto. Adoitan disporse sobre liñas artificiais, como camiños ou límites entre montes; sobre liñas naturais, como liñas de máxima pendente coincidentes coa separación creada por interfluvios, e sobre liñas de cumes. Debido a que acostuman ser chamadas "cortalumes», en moitas ocasións existe a expectativa de que consigan deter ou diminuír dun xeito significativo a progresión dos incendios, cousa que só ocorre nos de baixa intensidade ou nos flancos. Principalmente, as redes de devasas teñen como obxectivo dar seguridade aos equipos terrestres de extinción, aumentar a súa eficacia e posibilitar a aplicación de fogo técnico en contralumes e queimas de ensanche.

Os inconvenientes das devasas son os danos polo escoamento nas que se trazan en liña de máxima pendente, a necesidade de conservación periódica para evitar a rexeneración natural sobre elas e o negativo efecto paisaxístico.

Por outra parte, as áreas de defensa contra incendios son superficies relativamente amplas, cunha anchura de entre 40 e 100 metros, nas que se actúa para modificar o modelo de combustible cara a modelos de menor combustibilidade e velocidade de propagación. O obxectivo destas infraestruturas é aumentar a capacidade de intervención dos medios de ataque terrestres ao aumentar a súa seguridade, eficacia e produtividade.

Normalmente execútanse rareos, clareos e podas altas, acompañados de rozas. Poden manterse con pastoreo ou con reiteración de rozas. Outra alternativa de conservación é a queima prescrita. Cabe complementalas con devasas auxiliares e tamén adoitan aproveitar a existencia de pradarías, rasos ou rochedos.

Hai que destacar que todas as actuacións vistas até agora terían como escala a da unidade de xestión forestal, monte ou conxunto de montes. En xeral, a prevención estrutural non segue unha política transversal, encarando o territorio como un todo, e adoita considerarse como a suma de accións a escalas de xestión forestal que son executadas por diferentes axentes e organismos. A pesar de poder ser eficaz nos casos máis habituais de incendios, esta falta de accións xeneralizadas en territorios máis amplos non permite unha adecuada defensa fronte 
aos denominados grandes incendios forestais. Segundo Oliveira (2016), polo mesmo motivo de que estes «consomen" paisaxe, deben ser enfrontados mediante unha prevención exposta e levada a cabo á mesma escala.

As liñas xerais da prevención a nivel comarcal son as seguintes:

- Estruturar a vexetación en mosaicos, de entre decenas e centos de hectáreas. Trátase de evitar a continuidade en grandes extensións de igual tipo de masa. É evidente que este obxectivo non é sempre viable, sobre todo cando as condicións estacionais ou a realidade actual das masas impoñen unha monotonía que non é posible ou conveniente modificar.

- As masas mixtas, particularmente aquelas nas que hai presenza de especies brotadoras, amosan maior resiliencia por unha mellor rexeneración natural tras os incendios. Resulta, pois, conveniente, desde este punto de vista, inducir, en lugares axeitados, subpisos de frondosas en masas regulares de coníferas, especialmente se estas son artificiais. Tal intervención ten que ser coidadosa no que atinxe a non empeorar a estrutura vertical da masa en áreas moi extensas.

- Sobre as marxes de ríos e arroios, aproveitando as condicións de humidade, tratarase de manter ou inducir masas de especies ripícolas e de menor inflamabilidade. Estas formacións de chopos, salgueiros, bidueiros, freixos ou ameneiros dificultan o avance do lume, sempre que se manteñan ben rozadas. Pola contra, as valgadas de abundante matogueira son zonas de alto risco para a extinción e de gran velocidade de avance do lume.

- Manter e inducir, con regulacións adecuadas, certo pastoreo nos montes. Como xa se viu, a función do gando, controlando o desenvolvemento do sotobosque e consumindo combustibles de pequeno tamaño, confire ás masas unha menor combustibilidade relativa. Para conseguir con maior eficacia estes obxectivos, débense introducir altas cargas durante breves períodos de tempo, inducindo a consunción de todo o combustible potencial e evitando que o gando desprece as especies menos palatables, que non poucas veces resultan ser as máis inflamables.

- Desenvolver unhas redes complexas de compartimentación do territorio. Estas redes tradicionalmente se adoitan subdividir en varias escalas: redes primarias, executadas en terreos forestais e a unha escala inframunicipal, e redes secundarias, de nivel municipal ou local, que, atendendo a outras 
características do terreo e do risco de incendios, poden levarse a cabo aos lados de infraestruturas lineais (estrada, pista, ferrocarril, liñas eléctricas etc.) ou ao redor de núcleos urbanos, edificacións, polígonos industriais e zonas de recreo integradas nun espazo forestal, onde se reduce a carga de combustible, total ou parcialmente.

- Desenvolver mosaicos de parcelas de xestión de combustible, ou, na terminoloxía dos GRAF da Generalitat de Catalunya, puntos estratéxicos de xestión (PEG), que poidan dificultar a propagación e, sobre todo, constituír oportunidades de extinción. Nestes lugares, situados no interior dos compartimentos definidos polas redes primaria e secundaria, procédese á xestión de varios estratos de combustible e á diversificación da estrutura e composición das formacións forestais e de matogueira. A localización e dimensión dependen dunha análise de incendios pasados ou de simulacións. Aquelas superficies queimadas en anos anteriores, afloramentos rochosos, amplos espazos agrícolas e outros espazos libres de combustible poden, igualmente, constituír mosaicos.

\section{ONDE FACELO?}

\subsection{O espazo forestal}

O monte é unha realidade territorial complexa, integrante doutra realidade complexa como é o propio medio rural galego. Este, ademais da súa importancia económica e social, ten funcións medioambientais que se recoñecen e se acrecentan progresivamente. En particular, unha parte significativa dos montes galegos están incluídos na Rede galega de espazos naturais protexidos, desempeñan unha importante tarefa na conservación dos sistemas hidrolóxicos ou acollen numerosas e senlleiras mostras do patrimonio arqueolóxico ou cultural. Alén diso, as masas arborizadas e os solos forestais son un reservatorio básico de carbono que os converte en piares fundamentais para a loita contra o cambio climático.

A propia «delimitación» do que se entende por espazo forestal non é un asunto trivial. A definición legal do «monte ou terreo forestal» (ver cadro 1) é, no seu comezo, aparentemente simple, pero dun xeito gradual, a base de explicitar a súa 
casuística, unha serie de intervalos temporais para a súa consideración como tal e as súas relacións con outras lexislacións, como a urbanística, acaba resultando dunha complexidade excesiva. Esta complexidade definitoria e normativa terá efecto, como veremos, na propia «ordenación» do espazo.

Cadro 1. Definición de monte segundo a Lei 7/2012, do 28 de xuño, de montes de Galicia (o destacado é noso)

Artigo 2. Concepto de monte ou terreo forestal

1. Para os efectos desta lei, enténdese por monte ou terreo forestal todo terreo en que vexetan especies forestais arbóreas, arbustivas, de matogueira ou herbáceas, sexa espontaneamente ou que procedan de sementeira ou plantación, que cumpran ou poidan cumprir funcións ambientais, protectoras, produtoras, culturais, paisaxísticas, sociais ou recreativas.

Teñen tamén a consideración de monte ou terreo forestal:

a) Os terreos ermos, os rochedos e os areais.

b) As construcións e as infraestruturas destinadas a servizo do monte en que se localizan, así como os equipamentos e as infraestruturas de uso sociorrecreativo.

c) Os terreos de antigo uso agrícola e con polo menos dez anos continuados de abandono, sempre que adquirisen sinais inequívocos do seu carácter forestal, cando formen parte de superficies continuas de polo menos 5 hectáreas, agás que se trate de terreos que estean incluídos con ese fin nun banco de terras ou instrumento semellante.

d) Todo terreo que, sen reunir as características descritas anteriormente, se adscriba coa finalidade de ser repoboado ou transformado á actividade forestal, de conformidade coa normativa aplicable.

e) Os enclaves forestais en terreos agrícolas coa superficie mínima de 5 hectáreas, a non ser que se compoñan os ditos enclaves de masas de especies forestais de frondosas do anexo 1 cunha idade media de polo menos dez anos, diminuíndose, para estes casos, a dita superficie mínima ata 1 hectárea.

2. Non teñen a consideración de monte ou terreo forestal:

a) O solo urbano e o solo de núcleo rural.

b) 0 solo urbanizable delimitado, coas excepcións sinaladas na disposición transitoria quinta.

c) Os terreos de dominio público, agás os que integran o dominio público forestal.

d) Os terreos rústicos de protección ordinaria destinados a cultivo agrícola.

e) Os terreos rústicos de especial protección agropecuaria, sen prexuízo do establecido no apartado seguinte deste artigo e no artigo 61 desta lei.

3. En todas as categorías de solos rústicos de especial protección os aproveitamentos forestais rexeranse polo disposto nesta lei en todo aquilo en que non se lles aplique a súa normativa específica.

(Redacción segundo a modificación dos apartados 2.e) e 3 polo artigo 49 da Lei 2/2017, do 8 de febreiro).

\subsection{A ordenación do territorio}

En Galicia, o territorio é o resultado de milleiros de anos de intervención humana que transformou unha pretérita paisaxe natural nunha paisaxe funcional. En tempos pasados a velocidade do cambio (aínda que supuxese transformacións 
radicais) era lenta e, deste xeito, propiciouse a asimilación da paisaxe funcional como unha paisaxe cultural. Actualmente as mudanzas prodúcense cunha grande intensidade e rapidez e, na maioría dos casos, sen integración entre elas. A irrupción do transporte motorizado de persoas e mercancías rachou cun modelo tradicional de hábitat diseminado, pero estruturado de acordo cunha rede de unidades produtivas rurais e cidades como centros de intercambio. No entanto, o principal factor de alteración no patrón territorial non se explica só pola fuxida da aldea cara á cidade, senón tamén pola segunda onda de fuxida das cidades cara ás súas periferias polo fracaso no seu crecemento ordenado e a carestía da vivenda en períodos especulativos. Desta forma, as vilas e cidades foron substituídas por conglomerados construídos con tipoloxías e usos diversos, cunha dificultade de dotación de servizos, nunha matriz fractal de natureza pseudorrural onde algúns dos usos se manteñen, pero a maior parte dos residentes xa non gardan relación funcional coas parcelas non edificadas, o que as converte nun mero reservatorio de espazo edificable.

A análise das mudanzas na utilización da terra entre 1985 e 2005 realizada por Corbelle e Crecente (2014) indica que, nese período, o 43,2 \% da superficie total de Galicia cambiou de uso. Ademais, esa porcentaxe de mudanza foi moi constante nas distintas categorías; é dicir, Galicia mantivo unha matriz de aproximadamente o $50 \%$ estable en cada unha das tipoloxías, mentres que a outra metade mudou ao resto das clases (táboas 3 e 4). Aínda que con diferenzas territoriais, nese período aumentou a superficie urbanizada e o arboredo, diminuíu a ocupada pola agricultura e a gandaría e grandes áreas do territorio quedaron abandonadas. A comparación con datos da capacidade produtiva do chan revela que, en xeral, a urbanización e o mantemento do uso agrícola ou gandeiro tiveron lugar principalmente nas terras de maior calidade produtiva, mentres que a forestación se concentrou en terras de calidade intermedia e o abandono afectou ás de peores características.

A expansión da denominada interface urbano-forestal (ou urbano-rural segundo outros autores), asociada á crecente dispersión do sistema de asentamentos e á progresión da vexetación natural, constitúe unha dinámica territorial preocupante. Este proceso de cambio «turbulento» do uso do solo supón un dos elementos que máis está a contribuír a incrementar a vulnerabilidade fronte a un tipo de incendio que pode non só alcanzar as áreas edificadas, senón tamén pro- 
Táboa 3. Matriz de cambio de uso do solo en Galicia (1985-2005) segundo Corbelle e Crecente (2014)

\begin{tabular}{|l|r|r|r|r|r|r|}
\hline & \multicolumn{5}{|c|}{ Clase do ano 2005 } & Total de \\
\cline { 1 - 5 } Clase do ano 1985 & 1. S. ag. & 2. Mat. & 3. Arb. fr. & 4. Arb. pr. & 5. Impr. & $\mathbf{1 9 8 5}$ \\
\hline 1. Superficie agrícola & 520505 & 106571 & 74814 & 158253 & 67834 & 927977 \\
\hline 2. Matogueira & 130901 & 504851 & 90623 & 235249 & 17554 & 979178 \\
\hline 3. Arboredo: frondosas & 25047 & 22244 & 68797 & 32349 & 2482 & 150919 \\
\hline 4. Arboredo: produtor & 94931 & 131497 & 32516 & 551264 & 23745 & 833953 \\
\hline 5. Improdutivo & 10690 & 12146 & 2401 & 8031 & 34298 & 67566 \\
\hline Total de 2005 & 782074 & 777309 & 269151 & 985146 & 145913 & 2959593 \\
\hline
\end{tabular}

Táboa 4. Superficie estable ao cambio de uso do solo en Galicia (1985-2005) segundo Corbelle e Crecente (2014)

\begin{tabular}{|l|c|c|c|}
\hline & $\mathbf{2 0 0 5}$ & \multicolumn{2}{|c|}{ Superficie estable (1985-2005) } \\
\hline Superficie agrícola & 927977 ha & 520505 ha & $56,10 \%$ \\
\hline Matogueira & 979178 ha & 504851 ha & $51,60 \%$ \\
\hline Arboredo: frondosas & 150919 ha & 68797 ha & $45,60 \%$ \\
\hline Arboredo: produtor & 833953 ha & 551264 ha & $66,10 \%$ \\
\hline Improdutivo & 67566 ha & 34298 ha & $50,80 \%$ \\
\hline Total & 2959593 ha & 1679715 ha & $56,80 \%$ \\
\hline
\end{tabular}

pagarse no seu interior. Esta extensión da ameaza a bens e persoas provoca, ademais dun incremento do risco, unha crecente complexidade nos labores de prevención e, sobre todo, de extinción, xa que fai que xurdan uns problemas específicos, distintos nun grao substancial dos provocados polos incendios puramente forestais ou urbanos.

Chas-Amil et al. (2013) observaron nas súas análises que o $69,7 \%$ das edificacións de Galicia se sitúan en espazos clasificables como interface urbano-forestal/rural. Alén diso, de entre estas áreas, aquelas que contan cunha maior frecuencia de ignicións (chegando a máis dun punto por quilómetro cadrado) son aquelas que presentan aglomerados densos ou maior fragmentación forestal, ou ambos. 
Despois de máis de trinta anos de autonomía galega, a ordenación do territorio mantense como unha materia pendente. Un repaso do estado de desenvolvemento e aprobación de distintas figuras de ordenamento urbanístico indica que menos dun terzo dos concellos galegos teñen o seu planeamento adaptado á LOUG e 40 non dispoñen de planeamento (táboa 5).

Táboa 5. Figuras de planeamento urbanístico nos concellos de Galicia

\begin{tabular}{|l|c|}
\hline PXOM adaptado á LOUG & 96 \\
\hline PXOM/POMR adaptado á Lei 1/1997 & 44 \\
\hline PXOM/POMR ao abeiro da D. T. 3a da LOUG & 22 \\
\hline NSP/PXOU anterior á LASGA & 14 \\
\hline NSP/PXOU adaptado á LASGA até a Lei 7/1995 & 63 \\
\hline NSP/PXOM entre a Lei 7/1995 e a Lei 1/1997 & 20 \\
\hline Simple delimitación do solo urbano & 16 \\
\hline Sen planeamento & 40 \\
\hline & Total de concellos \\
\hline
\end{tabular}

Fonte: SIOTUGA (http://www.planeamentourbanistico.xunta.es/siotuga) [última consulta: decembro, 2018]

A conxuntura de parálise da actividade construtiva ocorrida tras a crise de 2008 non foi aproveitada para cambiar o modelo de consumo incontrolado e especulativo de espazo. Tampouco foi alterado o modelo de financiamento municipal, para que deixase de ser totalmente dependente dos ingresos xerados pola actividade urbanística. A non-existencia destas correccións fai que a aparente recuperación económica dos últimos anos veña a reincidir nos mesmos problemas que foron expostos en parágrafos precedentes.

A manifesta dificultade amosada durante décadas para planificar o crecemento ordenado do urbanismo galego fai dubidar de que os instrumentos inspirados na mesma filosofía, a da planificación urbanística, sexan axeitados para traballar na ordenación do espazo rural e, en particular, do forestal.

Gondar (2007) denuncia que, tradicionalmente, as zonas urbanas consideraron o rural como «o espazo baleiro entre grandes núcleos urbanos cunha especie de xardineiros provisionais que o coidan mentres non se precisen máis metros para edificar» e «o receptor resignado (e gratuíto) das infraestruturas que non 
caben ou non interesan no mundo urbano». Do mesmo xeito, coa coartada de aquelas sentírense ameazadas polos novos incendios forestais, non se pode só mirar ás áreas rurais desde as cidades co fin de establecer unha maraña de restricións sobre o seu desenvolvemento sen pretender transferir recursos ou compensacións.

\subsection{A ordenación e a planificación forestais}

\subsubsection{Concepto e orixe da ordenación forestal}

Enrique Mackay, en 1944, baseándose na definición que deu a finais do século pasado Lucas de Olazábal, escribiu que «ordenar» un monte é «organizalo conforme ás leis económicas, sen infrinxir as biolóxicas que a investigación silvícola e a epidométrica revelan». O mesmo Mackay establecía catro condicións básicas para a ordenación: persistencia, rendemento sostido, máximo rendemento (optimización das utilidades) e a "condición de extensión suficiente», da que se falará máis adiante.

Deste xeito, os métodos clásicos de ordenación buscan, ademais de, obviamente, garantir a tal persistencia e posible mellora das masas forestais, obter un rendemento sostido da produción do monte mediante a consecución dunha determinada estrutura global das formas principais de masa, establecida conforme a uns modelos teóricos dados de organización do monte, ou mediante a aproximación á dita estrutura. Estes métodos, en xeral caracterizados por unha enorme rixidez, non resistiron o paso do tempo e o cambio dos tempos, a pesar «da beleza estática e da seguridade infantil que proporcionaban ao proporen un sistema formado por cousas claras e ben delimitadas» (Garitacelaya 2008).

O mesmo concepto de ordenación veu experimentando unha profunda mudanza, grazas á experiencia acumulada de máis dun século desde a súa concepción e aplicación, con discutible grao de implantación, a pesar de loables e contadas excepcións.

É un lugar común que, á hora de falar de xestión forestal, se empregue como indicador a superficie sometida a «plans de xestión aprobados pola Administración» (en sentido amplo). En España, tomando como referencia o propio Ministerio competente, só existen proxectos de ordenación ou instrumentos de plani- 
ficación análogos para o $28 \%$ da superficie forestal pública española e para o $6,5 \%$ da privada. Estas modestas cifras serían moi inferiores se só fosen consideradas aquelas superficies que teñen os seus plans minimamente actualizados ou vixentes ou onde eses documentos se empregan como guía de xestión efectiva.

Isto fai dubidar, como moi pouco, de se existen disfuncións entre o seu deseño, obxectivos, custos, utilidade e repercusións legais, para moitas das realidades forestais (tipo de producións, tamaño da unidade de xestión ou natureza da propiedade). En palabras de Garitacelaya (2008):

Aínda quedan [...] montes nos que se aplicou [a ordenación] na prehistoria do coñecemento da xestión forestal, e nos que contra vento e marea, á conta de grandes sacrificios e altos custos, se manteñen como museos vivos, ou como monumentos á dificultade de moitos forestais de adaptárense aos tempos e ao avance dos coñecementos.

\section{Converxendo con estes argumentos, Saura (2009) afirmaba que}

na práctica os métodos de ordenación clásicos, ou a mesma necesidade de sequera seleccionar ou identificar un deles en concreto, [esmorecen] nestes momentos en moitas zonas do noso país. Os xestores atópanse con que en ocasións ningún deles é especialmente adecuado para os obxectivos perseguidos na ordenación dun monte ou espazo forestal concreto, ou que, sen resultaren inadecuados, a elección dun ou doutro resulta ser practicamente indiferente para os efectos das medidas que adoptar dentro do plan especial, que é o que terá vixencia e aplicación real no monte. Esta progresiva maior importancia do plan especial foi deixando as previsións do plan xeral como puramente indicativas e con cada vez menor relevancia [...], proceso acentuado polas tendencias actuais de aplicar unha xestión adaptativa [...], até chegar a deixar en moitos casos a elección do método de ordenación como un requisito puramente formal sen impacto real na planificación e xestión real que necesita o monte de acordo cos estándares actuais.

Segundo Garitacelaya (2008),

[P]ara un forestal español do século XX o estudo e a elección de cal dos métodos de ordenación debía aplicar era unha cuestión importante. Pero nos últimos vinte anos a súa supervivencia debeuse máis á inercia do tempo e á dificultade do alumeamento dos 
novos paradigmas. Non evolucionaron os métodos senón a mesma concepción da ordenación, que acabou por acantoar a «cuestión do método». Os «métodos de ordenación» deixaron de ter relevancia, malia que aínda atopen un lugar e unha autoridade [...].

Esta tendencia (ou necesidade nalgúns casos) de non decantarse por ningún método de ordenación concreto preestablecido nin axustar a xestión nun monte a el deu en chamarse, nos últimos anos, o «método de ordenación por poboamentos forestais», cando en realidade vén a consistir (permítase a simplificación) en elaborar un plan de xestión sen buscar nin adoptar ningún método nin estrutura de monte globais concretos, aplicando en cada poboamento forestal, cantón ou unidade de xestión que se diferencie os tratamentos considerados máis convenientes atendendo ás necesidades e condicións de cada un deles. Como González et al. (2006) expoñen,

na ordenación por poboamentos forestais, a planificación a longo prazo é xeral e orientativa, esta baséase na definición de orientacións de xestión xerais para cada tipo de masa (modelos silvícolas), en asegurar a persistencia incidindo no equilibrio de clases de idade e en asegurar unha distribución adecuada no espazo dos tipos de cuberta forestal. Este marco xenérico de actuación concrétase en cada ordenación dando coherencia temporal á xestión, pero dun modo tan flexible como requira o xestor. A planificación a longo prazo constitúese a partir da suma das ordenacións sucesivas.

E engaden:

[E]n montes pequenos (e por tanto sen a cuarta premisa clásica da ordenación de montes de acordo con Mackay, a extensión suficiente, ou con esta premisa moi atenuada), este balance de clases de idade sería de moi difícil consecución, e por tanto debería obviarse.

Se o panorama da ordenación de montes en xeral non é moi alentador, cando deixamos atrás os montes públicos ou de xestión pública e analizamos o seu papel na xestión forestal privada e, en particular, a xestión de propietarios forestais particulares, comprobamos como permaneceu durante o último século á marxe dela, por complexa e por afastada da ortodoxia da ordenación de montes. 
Autores como Rojo et al. (1998) entendían que «[coa estrutura da propiedade particular en Galicia] resulta imposible a ordenación de montes, ao non cumprirse a condición de extensión suficiente, necesaria para a consecución do obxectivo dasocrático de rendemento sostido [de Mackay]». Tamén, a modo de ilustrativo exemplo, baste citar a Madrigal (1998), unha das autoridades académicas máis recoñecidas no campo da ordenación de montes, que, nun artigo denominado nin máis nin menos que «Problemática de la ordenación de masas artificiales en España», despacha o problema coa seguinte frase: «Deixando á parte a problemática da posible ordenación dos minifundios forestais, que requiriría non só solucións técnicas, senón de política forestal [...]».

Implicitamente, posturas como as dúas ilustradas acaban pretendendo afirmar, de maneira utópica, que non merece a pena adaptar métodos á realidade: é moito mellor afrontar a parte máis sinxela desta e esperar (infrutuosamente) a que a realidade converxa coa ortodoxia.

\subsubsection{Os instrumentos de ordenación forestal noutros paises}

As mesmas palabras e conceptos de «ordenación» e "métodos de ordenación», que están a ter unha longa supervivencia na práctica e a xerga dos forestais españois, hai moito tempo foron abandonados noutros países. Alí onde deixaron atrás estas polémicas sobre métodos e clasificacións fálase simplemente de forest management. A este respecto, é significativo que, no dicionario da Sociedad Española de Ciencias Forestales, o termo inglés management sexa o elixido como tradución tanto da palabra ordenación como da palabra xestión.

Cadro 2. Definicións de ordenación e xestión

Ordenación: Silv. e pascic. Proceso de análise, diagnóstico e planificación dun territorio que leva á programación de actuacións para conseguir a máxima rendibilidade sostida, económica e ecolóxica dun recurso, en conservación e mellora do medio en función das súas condicións naturais, dos outros usos e aproveitamentos existentes, da legalidade vixente e dos obxectivos pretendidos. Inglés: management

Xestión: Ord. for. e econom. Administración dun monte. Inglés: management

(Fonte: dicionario da Sociedad Española de Ciencias Forestales [2005])

Ademais, os conceptos imperantes, sobre todo no que se refire aos montes privados que presentan obxectivos principalmente económicos, buscan dotar o 
propietario ou xestor forestal de liberdade para establecer o seu propio «plan de negocio» e facilitar que o comunique aos responsables de velar polo interese xeral.

Esta idea abunda no concepto dado pola Society of American Foresters, que en 1950 definiu a ordenación de montes como «a aplicación de métodos comerciais e principios silvícolas ao manexo dun monte». Consecuentemente con esta, en 1966 a FAO definiuna como "toda a gama de actividades de dirección, ao nivel empresarial, que se executan para alcanzar os obxectivos fixados polo propietario».

Por exemplo, en Suecia a figura de referencia vén sendo, desde hai uns anos, o green forest management plan, no cal para cada propiedade se formulan uns obxectivos a longo prazo mediante a clasificación do terreo en catro clases-tipo: PG (produción con consideracións xenéricas de conservación), PF/K (produción con consideracións de conservación reforzadas), NS (xestión para a conservación) e NO (conservación íntegra, onde non se intervirá en absoluto). Existen uns límites de canta superficie mínima debe establecerse en cada unha das categorías excepto para parcelas inferiores a 20 hectáreas. Alén diso, é significativo facer notar que non hai ningún estándar oficial que dispoña que información teñen que conter estes plans ou que métodos se han de empregar para a súa elaboración. Con todo, normalmente a petición do propietario, o plan inclúe aspectos como inventarios detallados ou outras medicións, que ademais serven para axustar, pola súa exactitude final, a retribución que deben percibir os autores do plan.

Finlandia (Nuutinen 2006) apostou con forza pola elaboración de plans comarcais e rexionais, así como unha infraestrutura de datos espaciais e de inventario que poida ser usada a escala de propiedade. Os propietarios teñen a posibilidade de solicitar, a un custo de entre 7 e 10 /ha, a particularización da devandita información para as súas propiedades nun plan de xestión individual. Nun contexto moi parecido, no caso de Noruega (Eid 2006), a crítica por parte dos propietarios forestais sobre a utilidade dos plans e o seu custo fixo que boa parte dos «inventarios» se levasen a cabo sen traballo de campo tradicional.

As conclusións máis relevantes destes exemplos internacionais de planificación forestal en montes privados son as seguintes: 
a) Non se pode comparar a superficie forestal situada baixo este tipo de instrumentos coa «superficie forestal ordenada» en España, xa que finalidade, contido, custos e métodos difiren radicalmente.

b) Nestes países, en xeral a planificación en montes privados enténdese como unha ferramenta de axuda ao silvicultor na que se pon en xogo a información que producen ou posúen os organismos públicos forestais.

c) Os traballos de inventario que debe sufragar o propietario forestal dependen do seu mero interese en obter máis coñecementos e cuantificacións sobre o estado do seu monte.

d) Desde o punto de vista do interese público, búscase que os plans sirvan para que os propietarios forestais coñezan e apliquen as restricións legais sobre áreas de conservación e demais elementos.

\subsubsection{A ordenación forestal no marco xurídico}

A Lei 43/2003, de montes (LBM), coas modificacións aprobadas pola Lei 10/2006, a Lei 21/2015 e a Lei 9/2018, así como diversas sentenzas do Tribunal Constitucional, establece no seu artigo 33 o seguinte:

1. As administracións públicas impulsarán técnica e economicamente a ordenación de todos os montes.

2. Os montes declarados de utilidade pública e os montes protectores deberán contar cun proxecto de ordenación de montes, plan dasocrático ou outro instrumento de xestión equivalente.

3. A elaboración dos ditos instrumentos farase a instancia do titular do monte ou do órgano forestal da comunidade autónoma e os instrumentos deben ser aprobados, en todo caso, por este último.

4. O contido mínimo dos proxectos de ordenación de montes e plans dasocráticos determinarase nas directrices básicas comúns para a xestión forestal sostible e o aproveitamento de montes establecidas no artigo 32. A elaboración destes instrumentos deberá ser dirixida e supervisada por profesionais que conten con titulación forestal universitaria e deberá ter como referencia, de ser o caso, o PORF en cuxo ámbito se atope o monte. 
5. O órgano competente da comunidade autónoma regulará en que casos pode ser obrigatorio dispoñer dun instrumento de xestión para os montes privados non protectores e públicos non catalogados.

Ademais, na súa disposición transitoria segunda outorga un prazo de 25 anos para que os montes que estean obrigados a isto se doten dun instrumento de xestión forestal. Alén do anterior, aqueles que 15 anos despois da entrada en vigor da lei non tivesen instrumento de xestión aprobado non poderían acollerse, salvo excepcións, aos incentivos recolleitos nos artigos 63 e posteriores (estes prazos eleváronse de 15 e 10 anos, respectivamente, a 25 e 15).

No ámbito autonómico, a Lei 7/2012, de montes de Galicia (LMG), establece nos seus parágrafos 77.4, 77.5, 77.6 e 77.7 que aqueles montes públicos e veciñais, privados e agrupacións destes últimos que teñan superficies «en couto redondo» superiores a 25 hectáreas deberán dotarse dun plan de ordenación. No resto dos casos, é dicir, montes privados (sexa cal for a súa tipoloxía) de menos de 25 hectáreas en couto redondo, haberán de dotarse dun instrumento de xestión forestal ou terá que planificarse a súa xestión a través da súa adhesión expresa a referentes de boas prácticas e aos modelos silvícolas orientativos, segundo especies ou formacións forestais, previstos no artigo 76.3.

Tanto a LBM como a LMG recoñecen a enorme importancia de ordenar os terreos forestais, aínda que non dedican nada a xustificar esta importancia, coma se fose algo sobre o que non deberían albergarse dúbidas. Por tanto, sexa ou non razoado, e sen facer outras apreciacións sobre a idoneidade da dita medida, ha de considerarse a ordenación e a implantación de instrumentos de xestión forestal como un imperativo legal.

A modo de exemplo cabe citar que a LMG, no seu parágrafo 44.h, inclúe o "cumprimento do instrumento de ordenación ou xestión forestal» entre os deberes dos propietarios de montes privados. A pesar diso, recoñece entre os dereitos dos propietarios a «elaboración dos instrumentos de ordenación ou xestión forestal nas súas propiedades».

Para alén do dito, LBM e LMG vinculan o réxime de autorizacións de aproveitamentos forestais á existencia dun instrumento de xestión, e xorde unha evidente ameaza de que aqueles montes non ordenados queden fóra de calquera sistema de incentivos económicos que conten coa participación do Estado. 
A LMG, no seu apartado de definicións, en concreto na de instrumentos de ordenación ou xestión forestal, indica que «serven para facer unha planificación da xestión sustentable, co fin de que sexa socialmente beneficiosa, economicamente viable e medioambientalmente responsable». No seu artigo 77 establece:

1. A ordenación de montes ten como finalidade a conservación, mellora e protección dos recursos forestais, o seu rendemento sustentable e a máxima obtención global de utilidades. Estes fins deben contribuír ao desenvolvemento rural, á xeración de rendas, á fixación da poboación, á calidade paisaxística e ao mantemento da biodiversidade.

No seguinte parágrafo engade:

2. A ordenación de montes supón a organización no tempo e espazo, tecnicamente xustificada, dos recursos forestais, de todos os aproveitamentos do monte e das especificacións técnicas para a súa xestión sustentable.

Á parte da finalidade pola que o lexislador incluíu a obrigatoriedade de dotarse dun instrumento de ordenación ou xestión forestal, na práctica o devandito instrumento debería servir para estes fins:

a) Facilitar a obtención de autorizacións, permisos e comprobacións que a lexislación, en prol de salvagardar o interese xeral, impuxo sobre as actividades forestais privadas.

b) Dar, mediante o concurso da Administración, unha mínima seguridade xurídica ao propietario ou xestor forestal sobre a actividade a longo prazo que pretende levar a cabo nos seus montes ou parcelas.

c) Facilitar a comunicación a terceiras partes (entidades de certificación, usuarios etc.) sobre o tipo de xestión que desenvolver pola propiedade.

d) Avaliar, na extensión e coa precisión que a propiedade queira asumir, a xestión que ten que realizarse na parcela.

e) Definir as medidas básicas de prevención de incendios forestais que han de adoptarse.

En definitiva, a «ordenación» debe pasar a ser sempre un conxunto de compromisos bidireccionais, entre a propiedade e a sociedade (representada, na maior parte das ocasións, pola Administración competente), a respecto das liñas xerais de xestión que desenvolver nunha propiedade específica. 
É certo que, como moi a miúdo se expón, «a xestión sen planificación é simple improvisación». Malia todo, non é menos certo que, feito público ou non, o propietario forestal adoita ter un plan máis ou menos complexo da súa xestión, aínda que ás veces non pase dunha intención, unha expectativa ou incluso unha rutina. O que se dá con maior frecuencia é a planificación sen xestión, un mero exercicio tecnocrático afastado da realidade ou, no mellor dos casos, un documento obsoleto desde o minuto seguinte á súa redacción.

A ordenación en montes privados de carácter produtivo, a pesar do que parecen querer impor os textos lexislativos, non é un fin en si mesmo, senón un medio para unha mellor xestión e, sobre todo, para compartir información básica sobre «a empresa» do propietario. Non é un proxecto de investigación, nin un traballo de erudición: pola contra, debe ser un documento simple, ben estruturado, normalizado e manexable (e, até onde sexa posible, informatizado ou automatizado).

A SECF (2008) recoñeceu que «a planificación non serve de nada se non se aplica na xestión. Desde este punto de vista, podemos afirmar que "a mellor ordenación é a que se aplica”. Debemos, pois, facilitar a xestión forestal, cunha planificación realista, eficiente e que poida dar resposta ás necesidades da sociedade en cada momento». Por tanto, é preciso apostar por métodos e modelos de xestión ordenada, máis que por métodos de ordenación da xestión.

Normalmente, esta simplificación dos antigos conceptos e métodos ortodoxos xera ansiedade en colectivos técnicos e académicos. Mesmo con frecuencia se cualifica de falta de rigor, sumada a unha falta de control sobre a actividade forestal que pon en risco os valores que as administracións deben defender. Non obstante, se tomamos a suficiente perspectiva veremos que non é tal. A conservación e a protección dos montes foron abordándose ao longo do tempo mediante o despregamento dunha prolixa, e cada vez máis confusa, batería de figuras de protección, frecuentemente solapadas e que proceden de distintos ámbitos disciplinares.

A conservación e a protección dos montes veñen reguladas pola Lei, básica ao amparo do establecido no artigo 149.1.23 da Constitución española, de montes de 2003 (modificada en 2006 e 2015) e as correspondentes lexislacións autonómicas, que xeraron instrumentos como o Catálogo de montes de utilidade 
pública e o Plan forestal español de 2002, coas súas réplicas autonómicas; a eles, sen chegar á unidade de xestión, hai que engadir os Plans de ordenación de recursos forestais (PORF). Noutros ámbitos aparecen figuras como as de conservación da natureza (parque nacional, parque natural, Rede Natura 2000...), cada unha cos seus instrumentos de planificación (PORN, PRUG, plans directores...). Por outra banda, xorden planificacións específicas, como as de protección do patrimonio cultural, plans hidrolóxicos, plans de ordenación do litoral, directrices de ordenación do territorio e, amais diso, o conxunto de plans xerais de ordenación urbanística e municipal de cada un dos concellos.

Como se desprende da totalidade do anterior, e sen entrarmos aínda no nivel do monte, non parece que esteamos carentes de ferramentas legais de regulación e planificación do espazo forestal, senón máis ben ao contrario. Así, todo apunta a unha excesiva proliferación normativa, de difícil encaixe e arrevesada xerarquía.

A modo de exemplo desta situación, cabe citar o traballo de Ávalos (2017) sobre a xestión dun patrimonio rural familiar. Partindo dunha superficie total de 12,1742 ha, unha vez descontadas aquelas restrinxidas ao uso forestal, afectadas pola aplicación de distancias mínimas establecidas pola normativa e situadas en zonas de servidumes administrativas (augas, estradas...), resulta unha superficie efectiva de xestión de 4,0715 ha, é dicir, pouco máis dun terzo da superficie inicial (ilustracións 2 e 3).

Décadas de experiencia en ordenación de montes demostraron que, especialmente no que se refire a montes privados de mediano e pequeno tamaño, os instrumentos que configuraban as instrucións xerais para a ordenación de montes arborizados (IGOMA) son custosos e complexos, inclúen información prescindible e reiterativa, as súas prescricións adoitan ser abandonadas ao pouco tempo da súa redacción, a precisión alcanzada no inventario non xustifica os custos asumidos neles e até a data non supuxeron unha grande axuda á xestión nin á relación coa Administración forestal.

Tendo iso en conta, o desafío principal é entender, prioritariamente, a «ordenación forestal» como a organización no espazo e no tempo da silvicultura e, de maneira simultánea, como instrumento tanto para a declaración de intencións da propiedade como para a avaliación por parte da Administración responsable de velar polo interese xeral. 
Ilustración 2
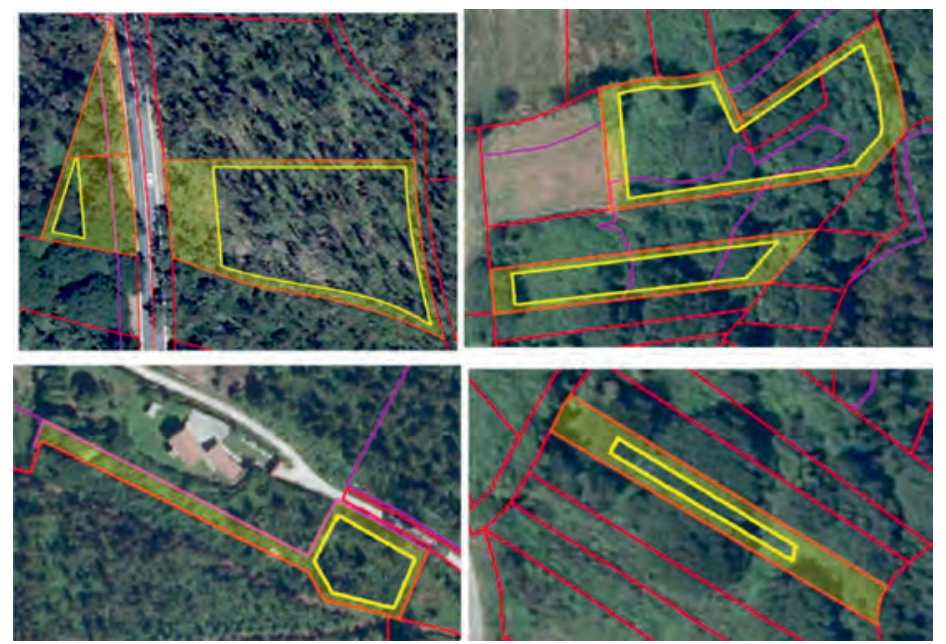

Ávalos (2017): Ejemplo de gestión de un patrimonio rural familiar según la Ley 7/2012 de Montes de Galicia Ilustración 3
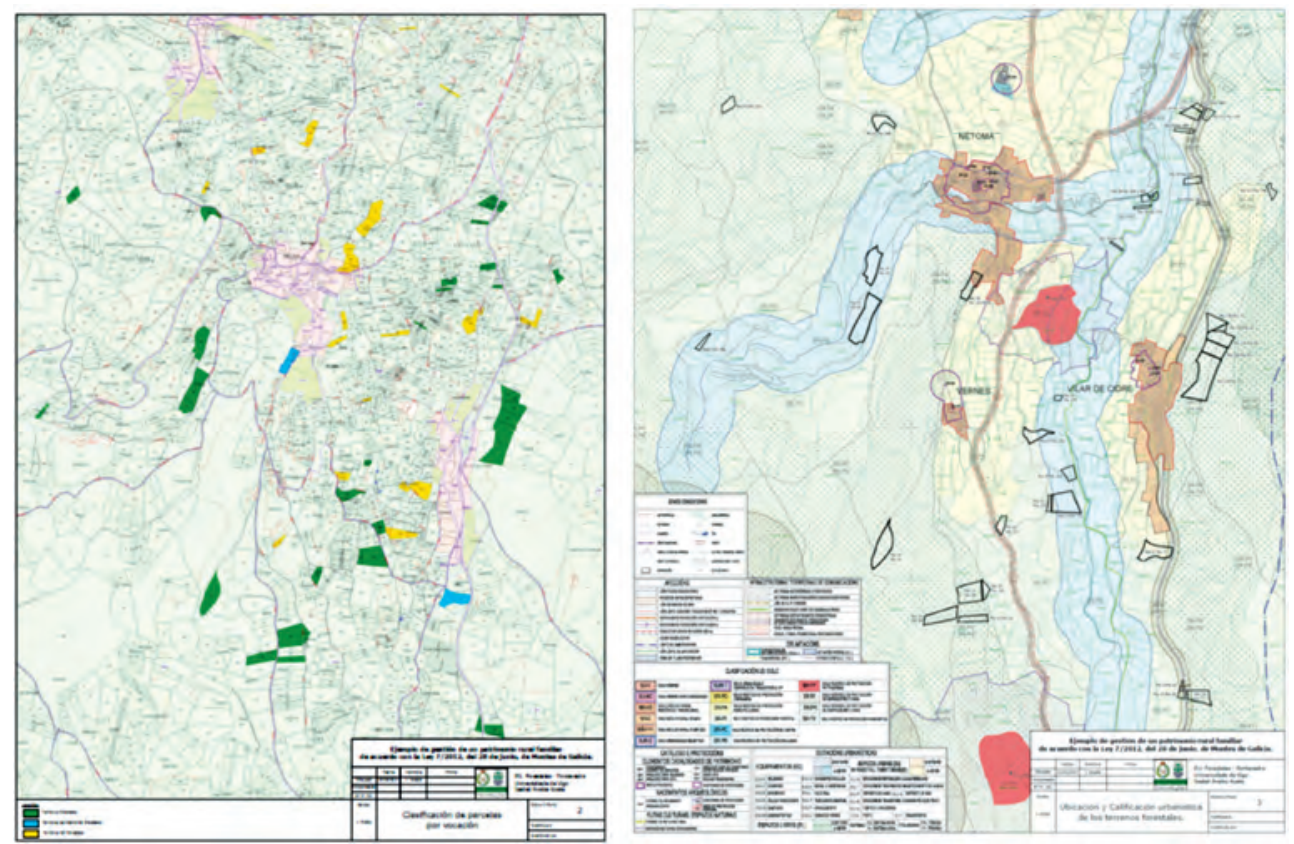

Ávalos (2017): Ejemplo de gestión de un patrimonio rural familiar según la Ley 7/2012 de Montes de Galicia 
Deste xeito, é en extremo interesante o camiño emprendido pola Lei 7/2012, do 28 de xuño, de montes de Galicia e, con posterioridade, o Decreto 52/2014, do 16 de abril, polo que se regulan as instrucións xerais de ordenación e de xestión de montes de Galicia. Este marco, aínda non totalmente posto en marcha e resumido na táboa 6 , tenta ser superador das eivas do marco normativo vixente desde os anos 70, para promover a planificación da xestión forestal sustentable do monte en Galicia, en especial nos montes particulares de pequeno tamaño.

É acertado que o Decreto trate de simplificar os requisitos administrativos mínimos do inventario, deixando no titular ou promotor do instrumento de xestión a potestade de levar a cabo traballos máis detallados, máis precisos, ou de utilizar as tecnoloxías e métodos que considere de utilidade para a súa xestión.

Resulta adecuado o emprego, como base territorial, da referencia catastral, en cumprimento da obrigación legal emanada do artigo 38 do Real decreto lexislativo $1 / 2004$, do 5 de marzo, polo que se aproba o texto refundido da Lei do catastro inmobiliario. No entanto, é oportuno advertir que esta obrigará a promover unha activa cooperación da Xerencia do catastro co fin de afrontar as numerosas solicitudes de corrección ás que haberá que facer fronte e mesmo para poder procesar solicitudes de instrumentos de xestión con referencias catastrais antigas ou en lugares onde o catastro non foi revisado recentemente.

De igual maneira, para o éxito do establecido no Decreto, será imprescindible a decidida colaboración dos distintos órganos da Administración que xestionan información que pasa a ser imprescindible para a redacción dos instrumentos de xestión. A publicación de documentación cartográfica, nun modo utilizable polos solicitantes, sobre aspectos como clasificación urbanística, patrimonio cultural e arqueolóxico, áreas afectadas por incendios forestais, datos cartográficos dos plans de distrito etc. condicionará en gran medida o éxito final da reforma proposta. Un grande avance é o que supón a recente publicación da base cartográfica do Plan básico autonómico e dos visores asociados aos trámites de autorización de aproveitamentos forestais (táboas 6 e 7). 
Táboa 6. Tipoloxía dos instrumentos de ordenación ou xestión forestal segundo o Decreto 52/2014

\begin{tabular}{|c|c|}
\hline Instrumento & Requisitos/Características \\
\hline $\begin{array}{l}\text { ADHESIÓN } \\
\text { A MODELOS } \\
\text { SILVÍCOLAS } \\
\text { E CÓDIGOS } \\
\text { DE BOAS } \\
\text { PRÁCTICAS } \\
\text { DE XESTIÓN } \\
\text { (MS) }\end{array}$ & $\begin{array}{l}\text { - Individual } \\
\text { - } \leq 15 \text { ha de propiedade en couto redondo } \\
\text { - Adhesión a modelos silvícolas (MS): un ou varios MS (só da Orde ou PORF) por } \\
\text { referencia catastral } \\
\text { - Compromiso de boas prácticas de xestión (BPX) definidos pola Orde ou polo PORF } \\
\text { - Por comunicación á Administración forestal do propietario } \\
\text { - Non redacción técnico-forestal nin codificación telemática } \\
\text { - Monte recoñecido baixo xestión forestal, só para os efectos das axudas FEADER } \\
\text { - Necesidade de autorización para cada actuación, de ser o caso } \\
\text { - Non-exención da distancia entre parcelas ( } 2 \text { m); Lei } 7 / 2012\end{array}$ \\
\hline $\begin{array}{l}\text { DOCUMENTOS } \\
\text { SIMPLES/ } \\
\text { CONXUNTOS } \\
\text { DE XESTIÓN } \\
\text { (DSX/DCX) }\end{array}$ & $\begin{array}{l}\text { - Un ou varios propietarios (comparten xestión) } \\
\text { - } \leq 25 \text { ha cada propiedade en couto redondo } \\
\text { - Individual/conxunto de propiedades } \\
\text { - Para cada referencia catastral: afectación ao réxime de protección, inventario forestal } \\
\text { (descritivo, estimado - non parcelas-), adhesión a MS e código de BPX (da Orde ou } \\
\text { PORF ou especificamente creado) } \\
\text { - Non é instrumento de ordenación (métodos), só de xestión (MS-BPX) } \\
\text { - Redacción por un técnico e codificación previa telemática } \\
\text { - Aprobación pola Administración forestal } \\
\text { - Non necesarias autorizacións administrativas (Rede Natura...) despois da aprobación } \\
\text { - Potestativamente, exención da distancia entre parcelas contiguas do mesmo instrumento }\end{array}$ \\
\hline $\begin{array}{l}\text { PROXECTO DE } \\
\text { ORDENACIÓN } \\
(P O)\end{array}$ & $\begin{array}{l}\text { - Individual/conxunto (mesmo xestor ou propietario) } \\
\text { - Montes de xestión pública e montes privados de > } 25 \text { ha en couto redondo } \\
\text { - Estudo da afectación de réximes de protección } \\
\text { - Inventario forestal estimado (parcelas só en superficies que cortar antes do final do plan } \\
\text { especial) } \\
\text { - Aplicación de métodos de ordenación: monte dividido en cuarteis de ordenación, } \\
\text { método de ordenación, creación de unidades (tramos, tranzóns...) } \\
\text { - Redacción por un técnico forestal e codificación previa telemática } \\
\text { - Aprobación pola Administración forestal } \\
\text { - Non necesarias autorizacións administrativas (Rede Natura...) despois da aprobación }\end{array}$ \\
\hline
\end{tabular}

Táboa 7. Número de instrumentos de xestión no rexistro de montes ordenados da Consellería do Medio Rural

\begin{tabular}{|l|r|r|r|r|r|r|r|}
\hline & \multicolumn{3}{|c|}{$\mathbf{0} \mathbf{3 0 / 1 1 / 2 0 1 8}$} & \multicolumn{2}{c|}{ Antes de 16/4/2014 } & \multicolumn{2}{|c|}{ Despois de 16/4/2014 } \\
\hline Tipo de instrumento & $\mathbf{N}^{\mathbf{0}}$ & Superficie (ha) & Sup. media (ha) & $\mathbf{N}^{\mathbf{0}}$ & Superficie (ha) & $\mathbf{N}^{\mathbf{0}}$ & Superficie (ha) \\
\hline $\begin{array}{l}\text { Documento simple } \\
\text { de xestión }\end{array}$ & 5 & 78,68 & 15,74 & - & - & 5 & 78,68 \\
\hline $\begin{array}{l}\text { Plan técnico de } \\
\text { xestión }\end{array}$ & 175 & 28962,25 & 165,50 & 171 & 28910,43 & 4 & 51,82 \\
\hline $\begin{array}{l}\text { Proxecto de } \\
\text { ordenación }\end{array}$ & 570 & 197625,54 & 346,71 & 393 & 152190,08 & 177 & 45435,46 \\
\hline Outros análogos & 3 & 74,58 & 24,86 & 3 & 74,58 & - & - \\
\hline Total xeral & 753 & 226741,05 & 301,12 & 567 & 181175,09 & 186 & 45565,96 \\
\hline
\end{tabular}




\subsubsection{A ordenación a escala de paisaxe}

Se aceptamos, pois, a «ordenación» como a organización da silvicultura no espazo e no tempo, esta debería incluír a organización da silvicultura preventiva a escala de unidade de xestión.

Cabe lembrar que a maior parte das unidades de xestión forestal posúen un escaso tamaño (o $80 \%$ das parcelas forestais son inferiores a media hectárea [Picos 2015]). Ademais, algunhas das principais medidas preventivas de incendios forestais descritas en apartados anteriores débense deseñar e executar a unha escala de «paisaxe». Ambas as dúas circunstancias obrigarían, pois, a analizar unha hipotética escala de "ordenación ampliada», entendida como artellamento da silvicultura preventiva no espazo e no tempo a escalas superiores ás da unidade de xestión e inferiores á comarcal.

A lexislación autonómica (artigo 74 da LMG) prevé a aprobación de plans de ordenación dos recursos forestais (PORF) como instrumentos de planificación forestal, que afectarán preferentemente a cada distrito forestal, en canto territorios de condicións xeográficas, socioeconómicas, ecolóxicas, culturais ou paisaxísticas homoxéneas. O contido destes plans (estipulado no artigo 76) deberá coordinarse cos correspondentes plans de prevención e defensa contra os incendios forestais de distrito establecidos no artigo 15 da Lei 3/2007, do 9 de abril, de prevención e defensa contra os incendios forestais de Galicia.

O plan de prevención e defensa contra os incendios forestais de distrito (PPDCIFD) desenvolve as orientacións previstas na planificación establecida no Plan de prevención e defensa contra os incendios forestais de Galicia (PLADIGA), facilitando un marco de referencia para levar a cabo a prevención, defensa e extinción de incendios forestais a escala de distrito forestal, adecuado ás características, problemática e necesidades na materia de cada territorio forestal, minimizando o número de incendios e as superficies afectadas por eles.

A Lei 3/2007 establece que a consellaría competente en materia forestal poderá crear e aplicar programas especiais de intervención no ámbito dos PPDCIFD para áreas forestais contiguas a infraestruturas de elevado valor estratéxico e para áreas forestais estratéxicas de elevado valor, de acordo co establecido nos PORF. Igualmente, nos ditos plans poderán establecerse zonas de actuación preferente para os efectos de prevención de incendios, no marco de cuxa xestión será 
posible concertar convenios de colaboración coa propiedade ou axudas específicas.

No tocante a cada unha das zonas de alto risco de incendio (ZAR) definidas pola Orde do 18 de abril de 2007, a Lei prevé que sexa elaborado un plan específico de defensa, que se integrará no PPDCIFD e que, entre outros aspectos, terá en conta as medidas e os traballos preventivos aplicables a elas. Estes traballos preventivos incluirán devasas, vías de acceso e puntos de auga que «deben realizar as persoas titulares dos montes da zona» [sic], así como os prazos e as modalidades de execución, «sen prexuízo da colaboración coas administracións públicas» $[$ sic].

Por último, os PPDCIFD atenderán exhaustivamente ao disposto na Lei 4/2015, do 17 de xuño, de mellora da estrutura territorial agraria de Galicia, en canto á declaración de perímetros abandonados de leiras de vocación agraria por parte do órgano superior competente en materia de agricultura cando poidan supor risco de incendios forestais, ben pola non-aplicación ou ineficacia das medidas contidas nos correspondentes plans de xestión ou de ordenación forestal, ben pola inexistente xestión da biomasa ou polas reiteradas neglixencias no uso do lume en prácticas de xestión agroforestal ou doutros conflitos que deviñeron na reiteración de incendios nesas zonas, co consecuente perigo para as áreas habitadas próximas a elas.

Todas estas disposicións apuntan ao decisivo papel que PPDCIFD e PORF deberían ter na execución de medidas preventivas en escalas superiores á da unidade de xestión forestal.

A realidade, hoxe en día, non indica o mesmo. Desde a aprobación da LMG, non se fixo o propio con ningún PORF e, once anos despois da aprobación da Lei 3/3007, os únicos PPDCIFD foron os sancionados mediante a Orde do 13 de marzo de 2009 e non se adoptou ningún plan específico de defensa para as ZAR. Ademais, desde 2009, estes PPDCIFD nunca foron avaliados na súa execución nin revisados, malia que na súa definición figura que deben desenvolver as orientacións previstas no PLADIGA, que é aprobado anualmente. 


\section{QUEN E COMO?}

A propiedade forestal de Galicia é case na súa totalidade -98\%- de natureza privada. Aproximadamente dous terzos corresponden a propiedade privada individual e un terzo a propiedade privada colectiva (montes veciñais en man común).

Cando se producen episodios graves de incendios e, en particular, aqueles que afectan zonas próximas ás cidades, a reacción social e política tende a volver a súa mirada cara ao monte, buscando explicacións fáciles e rápidas e, en non poucos casos, reprochando ás áreas forestais que producisen esa situación de emerxencia.

No medio desta reacción, esquécese que os silvicultores e comunidades de montes son grandes afectados polos lumes e como tales merecen ser tratados. Non é frecuente explicitar publicamente o apoio a eles e en non poucas ocasións se deixa flotar unha néboa de «culpabilidade». O xuízo sobre as decisións que tomaron ou non os xestores forestais non adoita incluír unha discusión pausada sobre as alternativas reais, nun marco de mínima rendibilidade, que permitirían manter os combustibles forestais en condicións de menor dispoñibilidade e incrementar a diversidade de usos en zonas forestais.

Por outra parte, a propiedade vén sendo obxecto de tutela conceptualmente considerada como mera titularidade, con independencia do uso ou non-uso dela que fixese o propietario. Non se ten, en xeral, en conta a conducta dese uso, que, en case calquera senso, se considera lícito. A complexidade do marco legal e as novas esixencias da sociedade están dando paso a un concepto de explotación útil -individual e socialmente- dos bens. É dicir, a propiedade é un modo de acumular e conservar riqueza, pero tamén un medio para producila e para evitar danos sobre outras propiedades, bens ou servizos de interese público.

Nun territorio maioritariamente privado, onde a xestión directa, ao contrario que noutras áreas xeográficas, non corresponde aos poderes públicos, a misión da política forestal é a de servir de marco e, ao mesmo tempo, de panca para posibilitar a mellora da xestión de miles de axentes, compatibilizándoa coa defensa do interese xeral. 
Por tal motivo, débese afrontar a loita para superar a elevada fragmentación da propiedade, reverter o abandono das terras, fomentar a xestión agrupada e mellorar as condicións de produción, de forma que, complementariamente, aumente a competitividade da silvicultura e con ela a dunha boa parte do conxunto da cadea de valor.

\subsection{A necesidade de alternativas rendibles}

No caso de Galicia, a propiedade particular representa o $80 \%$ da superficie arborizada e achega o $90 \%$ das cortas anuais (XERA 2018). A superficie media é dunhas 0,25 ha (Picos 2015) e uns terreos tan reducidos dificultan a mecanización da silvicultura e os aproveitamentos forestais, encarecendo o seu custo até o extremo de poñeren en perigo a súa rendibilidade futura.

Os cambios acontecidos no mundo rural durante os últimos vinte anos, nomeadamente o abandono das explotacións agrarias, a redución da poboación activa agraria e o envellecemento da poboación residente no campo, xeraron unha transformación dese medio, incluída a conversión de terreos agrícolas en forestais, ben por acción, ben, en moitos casos, meramente por omisión. A emigración da poboación, o declive e desaparición da maioría das explotacións, o escaso interese agrario e a xubilación ou morte dos propietarios provocaron un cambio social de enorme alcance no agro galego, onde hoxe en día numerosas comarcas están a quedar practicamente despoboadas ou cun grao de envellecemento alarmante.

Xurdiu unha xeración de novos propietarios forestais, de natureza máis absentista, pola súa residencia afastada das súas propiedades, polo seu descoñecemento delas e pola súa falta de experiencia como produtores no medio rural.

Unha boa parte dos investimentos dos propietarios particulares de montes en Galicia, sen ser actividade económica principal, desempeña un papel de aforro non financeiro básico nas economías familiares de moitas áreas de Galicia. Segundo Confemadera (2014), o $9 \%$ das familias galegas obtiveron algunha renda procedente da venda de madeira.

O balance económico e os riscos dunha explotación forestal (que comece de cero), incluso sen contar o custo de adquisición do solo e con quendas 
«relativamente curtas», son, en termos financeiros en sentido estrito, pouco incentivadores (ilustracións 4 e 5). No obstante, as actividades forestais dos silvicultores privados, máis que a un concepto de «investimento», obedecen a un concepto de «aforro", mediante o cal se acumulan recursos a longo prazo mediante o uso dunha terra que herdaron, na maior parte dos casos. Actualmente o valor en recursos madeireiros acumulado no monte galego produtivo supón unha cantidade equivalente ao $7 \%$ ou $8 \%$ dos depósitos bancarios do país (Picos 2015). Este aforro amosou a súa importancia en momentos en que as familias tiveron que enfrontarse a situacións económicas difíciles, como as derivadas do desemprego.

Como xa foi analizado anteriormente neste documento, un dos factores máis prexudiciais que nas ultimas décadas sufriu este modelo foi a distorsión causada pola expectativa de especulación coa potencial urbanización do solo rústico (en especial nas comarcas máis poboadas). Unha axeitada ordenación do territorio e, sobre todo, o control sobre os procesos de cambio de uso son imprescindibles para a axeitada posta en produción nos longos prazos que require a xestión forestal.

$\mathrm{Na}$ liña do defendido por López-Iglesias (2018), todo o que queiramos que produzan os montes ten que ser pagado por alguén e debe responder a unha demanda real de bens ou servizos ecosistémicos. Non serven os usos impostos pola sociedade aos propietarios, sen compensación, como tampouco se pode basear o futuro dos territorios en alternativas meramente voluntaristas incapaces de manter a ceifa no medio prazo. Igual que se fan esforzos para, despois dos incendios, non perder o chan porque ten que ser sustento da masa forestal futura, a sociedade non pode permitir que se perdan xestores do territorio, «erosionados» despois de veren arder os seus montes.

$\mathrm{O}$ incremento da superficie forestal infraxestionada ou mesmo abandonada, ademais das obvias consecuencias desde o punto de vista produtivo, incrementa o risco de maiores e máis graves incendios, sobre todo nas áreas de interface urbano-forestal (ilustracións 4 e 5). 
Ilustración 4. Taxa interna de retorno (TIR) e necesidades financeiras para distintos modelos silvícolas dependentes de especie principal, quenda, produtividade e grao de mecanización

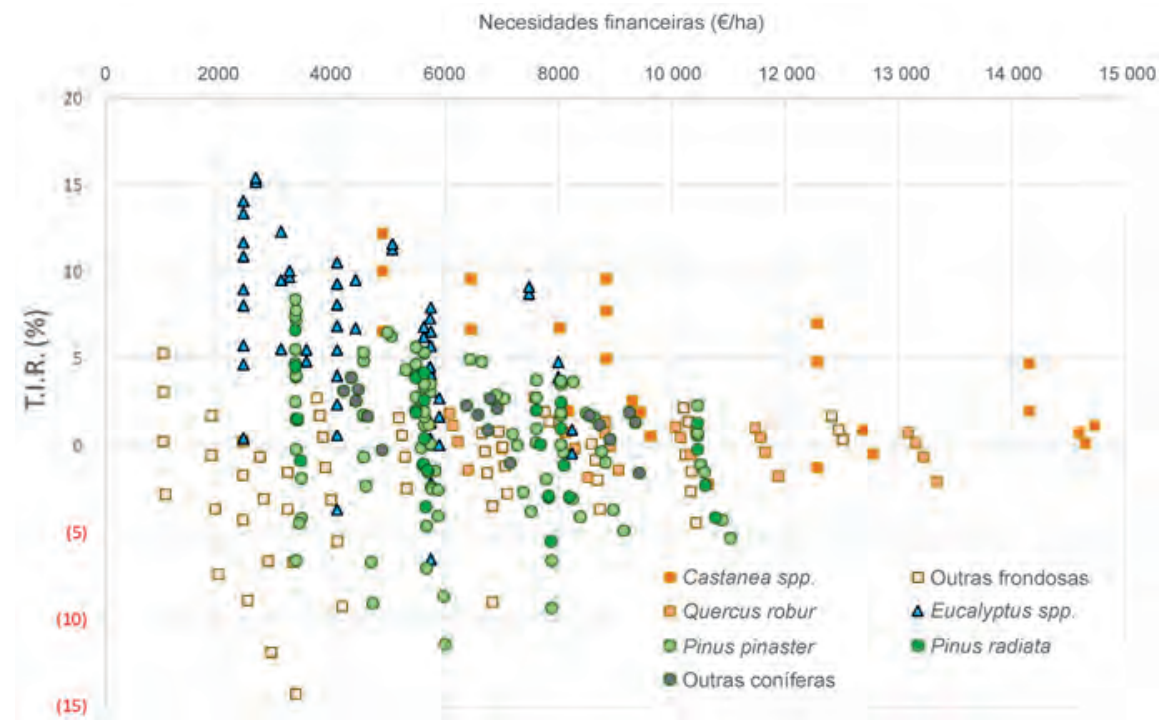

Fonte: Elaboración propia a partir dun informe da Asociación Forestal de Galicia (2017)

Ilustración 5. Necesidades financeiras e resultados para distintos modelos silvícolas dependentes de especie principal, quenda, produtividade e grao de mecanización

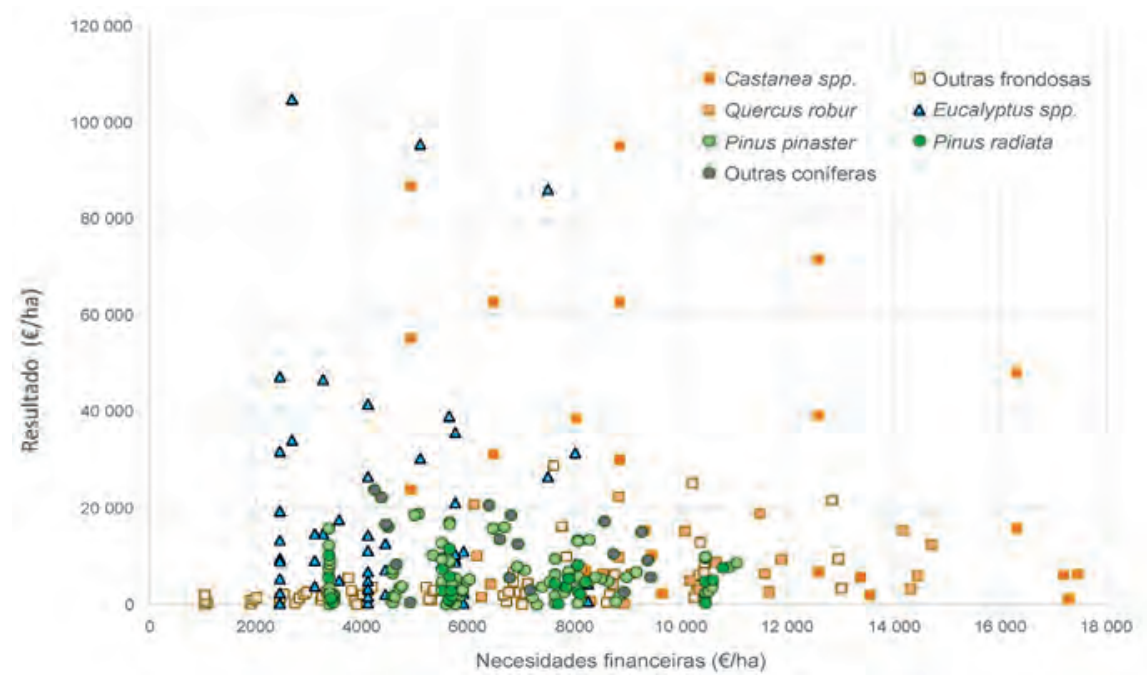

Fonte: Elaboración propia a partir dun informe da Asociación Forestal de Galicia (2017) 


\section{2. $\mathrm{O}$ abandono en áreas forestais}

Tendo en conta a modesta rendibilidade de moitas das alternativas forestais e a non-profesionalidade da maior parte dos silvicultores, non é estraño que os procesos de incremento da presión normativa ou impositiva se traduzan, ao contrario do que pretenden, en incrementos da superficie infraxestionada ou abandonada.

O abandono de terras e a consecuente diminución da superficie forestal obxecto de xestión activa constitúen unha preocupación importante nun gran número de rexións e países da Unión Europea. A definición dos conceptos de «abandono de terras» ou de «terra abandonada» non é unánime. Existen diversas aproximacións, entre as que destacan aquelas que entenden o abandono como un estado da terra (é dicir, analizado cun enfoque estático no tempo) e aqueloutras que o entenden como un proceso nunha escala temporal (analizado cun enfoque dinámico). De igual modo, é posible distinguir entre abandono dunha actividade e o propio abandono da terra (Corbelle e Crecente 2008).

En moitos casos, é difícil outorgar a cualificación obxectiva de «abandonadas» ás superficies forestais. Isto é debido a que usualmente veñen definidas por exclusión doutros usos ou actividades -como a agropecuaria ou a acción construtiva- ou mesmo pola evolución da vexetación tras o abandono das ditas superficies. Porén, o abandono en áreas forestais non é fácil de identificar sobre o terreo, unha vez que o crecemento da vexetación espontánea está condicionado pola actividade realizada e os longos prazos que poden mediar entre intervencións ou aproveitamentos silvícolas.

$\mathrm{Na}$ ilustración 6 móstrase unha aproximación alegórica ao proceso de abandono dos terreos forestais. Na devandita figura, enténdese o abandono como un proceso continuo no que poden distinguirse distintos estados, establecendo unha analoxía cun circuíto hidráulico composto por varios depósitos onde a auga flúe por gravidade. Deste xeito, pártese dun escenario óptimo (máxima altura e enerxía potencial) no cal a parcela está xestionada por un silvicultor activo e chégase a un estado, a menor cota e con menor enerxía potencial, no que se considera o abandono extremo (abandono irreversible).

No proceso de abandono, gradualmente vaise pasando por diversos estados intermedios, algúns dos cales poden englobarse dentro da fase de «semiabandono». 
Esta caracterízase porque a parcela segue aínda xestionada, recibindo algunha atención periódica, malia que progresivamente menos, e segue sendo, en todo caso, obxecto de aproveitamento. Ao mesmo tempo, comeza a haber unha certa «desidia» desde o punto de vista administrativo (por exemplo, o catastro xa non está actualizado, incúmprense ou descoñécense obrigacións normativas etc.). Este é un caso frecuente cando hai unha transmisión por herdanza e os novos propietarios xa non viven na contorna da propiedade ou a súa fonte principal de ingresos xa non está relacionada coa propiedade rural. O absentismo podería ser un caso particular desta categoría.

Cando a actividade na parcela cesa -e isto ocorre con frecuencia tras un aproveitamento ou un incendio- pero é aínda potencialmente «activable» polo propietario (este coñece a súa localización, se houbese unha oferta interesante podería vendela etc.), dicimos que a parcela se atopa no estado de «abandono reversible».

Se a situación segue deteriorándose, ou incluso se nese momento houbese un cambio de xeración, podería darse o caso de que a parcela xa non fose localizable polo propietario, ou até que a súa mera existencia fose descoñecida por el. Neste suposto diriamos que estamos nun estado de «abandono irreversible»: o estado ou destino da parcela non pode ser mudado polo mesmo dono dela. Propietario e propiedade aparecen totalmente desvinculados.

Como no caso dos depósitos sucesivos de auga, regresar a un estado anterior precisa dunha achega de enerxía ao sistema -un bombeo-. A enerxía necesaria para volver desde os estados inferiores ao estado inicial de «silvicultor activo" é progresivamente maior canto máis «abaixo» no circuíto se atope a auga. No caso do abandono, esta enerxía virá identificada co esforzo, económico, social ou normativo, requirido para activar o terreo. Por iso na liña punteada da figura se exemplifican medidas que van desde os incentivos, nos estados iniciais, até a intervención sobre a propiedade (expropiación, tutela administrativa...) nos finais.

Cando falamos de silvicultura preventiva a escala de paisaxe, debería empregarse a intervención pública sobre as áreas de abandono irreversible para desenvolver estratexias preventivas. Isto permitiría acadar obxectivos no establecemento de puntos estratéxicos de xestión ou na diversificación de combustibles, ou incluso favorecer permutas con propietarios sometidos a estas restricións noutras 
zonas. Tal política de presión sobre o abandono e incentivo sobre a xestión activa compatible representa unha oportunidade para fuxir do dilema de aplicar restricións que só afectarán a quen xestiona e non ao abandonado.

Obviamente, antes de aplicar medidas encamiñadas a reverter o circuíto, o primeiro obxectivo tería que ser frear o fluxo descendente, pechando as válvulas que separan cada un dos recipientes (en vermello na figura). Do mesmo xeito, para deter o proceso de abandono no territorio, antes (ou ademais) da toma de medidas ambiciosas para a reversión debería evitarse que o proceso seguise producíndose.

Ilustración 6. Representación alegórica do proceso de abandono dos terreos forestais

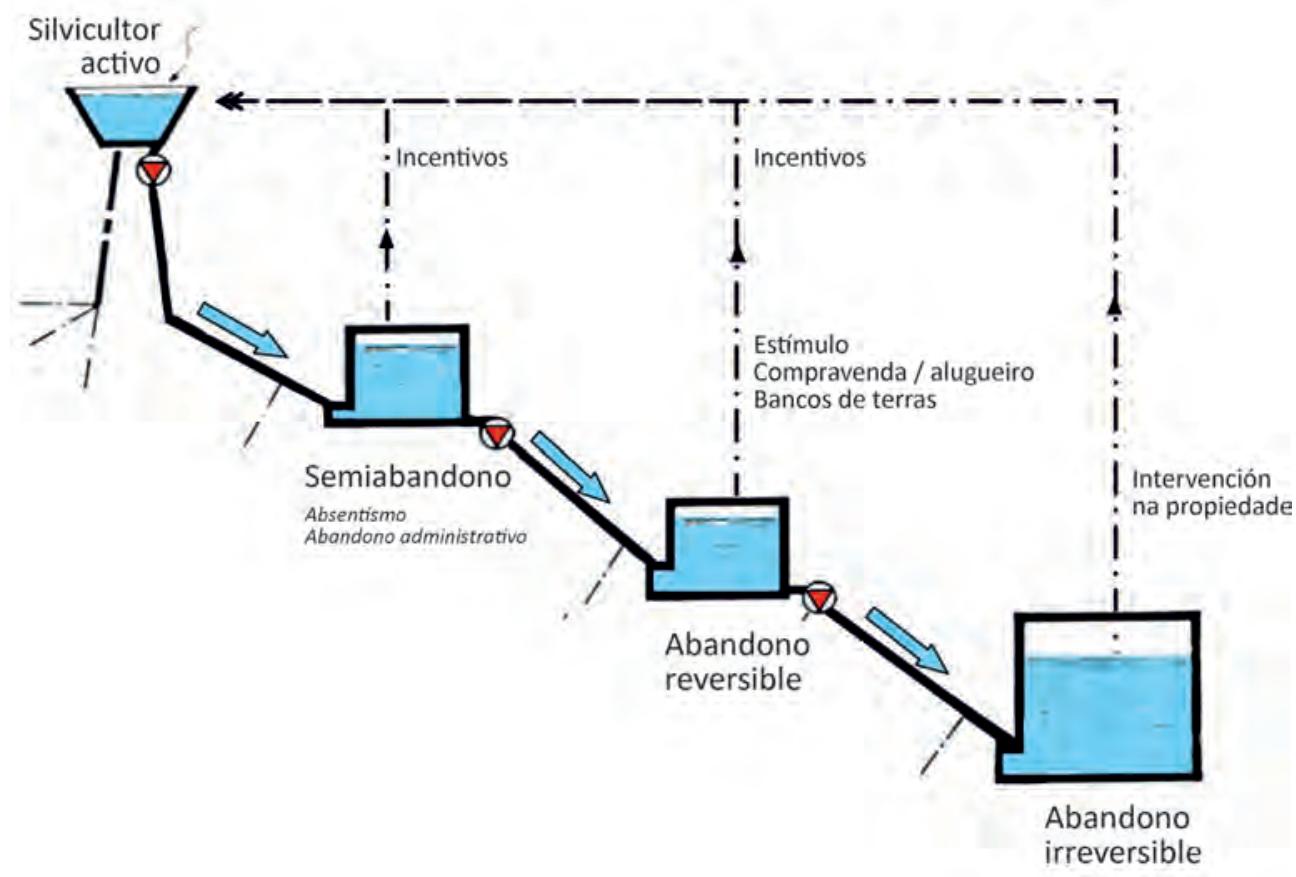

\subsection{A necesidade de segmentación das medidas}

Non é factible establecer de xeito nidio unha liña que separe a xestión forestal "correcta» da que non o é. A multiplicidade de posibles itinerarios silvícolas e os distintos valores que chegan a alcanzar as variables que poderían representar esa 
xestión obrigan a considerar a «bondade» da xestión forestal como un continuo, no cal normalmente é fácil distinguir os extremos, pero a gradación intermedia é, en moitos aspectos, sutil.

Supoñamos a existencia dunha función $\Phi$ que puidese representar de xeito sintético a «bondade» da xestión forestal (xestión forestal sostible, economicamente viable, socialmente axeitada e ambientalmente responsable) e que, ao mesmo tempo, estivese correlacionada cunha boa aplicación das medidas de silvicultura preventiva que foron indicadas en anteriores apartados. O que sería de agardar é que a distribución de frecuencias dos xestores forestais en función do valor de $\Phi$ puidese vir representada por unha curva unimodal convexa con certa asimetría (ilustración 7). Entón, un obxectivo da política forestal debería ser que a curva de $\Phi$, ou, polo menos, a súa maior área posible, se fose desprazando cara a maiores valores na parte dereita do gráfico (liña punteada da ilustración 7).

Ilustración 7. Aproximación gráfica ao proceso de segmentación e mellora da xestión forestal privada

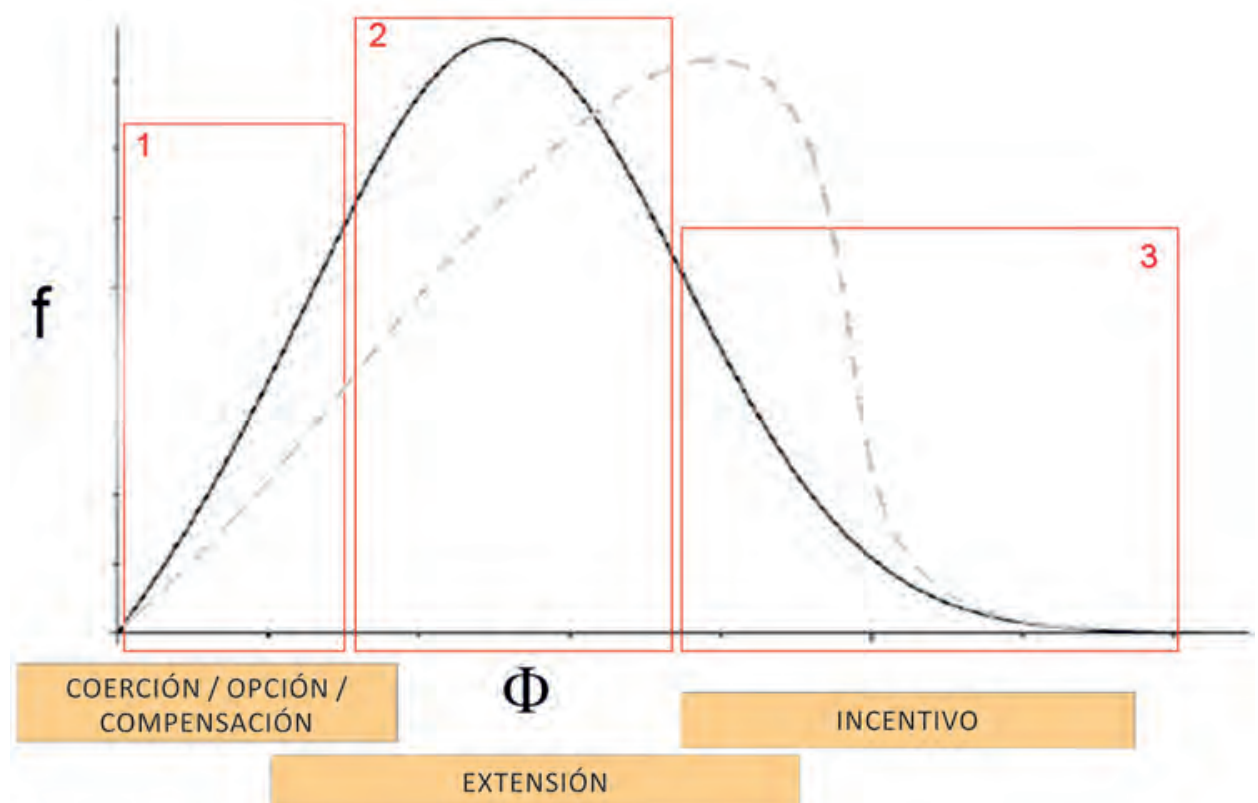

INVESTIGACIÓN E DESENVOLVEMENTO DE MELLORA E ALTERNATIVAS 
Dentro desta distribución poderíanse segmentar rexións con distinta problemática e, polo tanto, nas que tamén deberían aplicarse estratexias distintas.

A área correspondente á cola inicial (1), con valores máis baixos de $\Phi$, comprendería os xestores de prácticas máis afastadas do óptimo. Para estes casos, as principais ferramentas serían tanto aquelas de tipo coercitivo, nos casos en que non se estivese a cumprir a normativa, como a xeración de alternativas e compensacións para aqueloutros casos en que exista unha disfunción entre a expectativa de xestión ou produción por parte do silvicultor e a función preferente para o interese xeral. Este suposto é especialmente frecuente en espazos naturais protexidos e mesmo en áreas definidas para a xestión preventiva, puntos estratéxicos de xestión etc.

A zona central do gráfico (2) correspondería ao numeroso conxunto de xestores que teñen prácticas estándar para o territorio. Neste caso deberíanse aplicar ferramentas como a extensión, que permitiría que os silvicultores mellorasen a súa formación, as técnicas empregadas e o uso doutras alternativas que levasen a mellorar o valor da $\Phi$ da súa xestión.

A zona da cola superior (3) correspondería aos xestores que xa acadan valores elevados de $\Phi$, lindeiros o incluso superiores ao considerado como obxectivo. Estes xestores deberían ser recompensados con incentivos premium que tamén terían que servir de motivación para ser acadados por aqueles situados en partes máis baixas do gráfico.

Un proceso como este de segmentación dos xestores e das medidas que aplicar a cada unha das «tipoloxías» semella ser máis acaída que as aproximacións tradicionais. Normalmente aplícanse obrigas xenéricas, que non consideran diferencias entre territorios ou, o que é máis grave, entre tipo de xestión, que ao final acaban sendo incapaces de mudar a situación nas parcelas «infraxestionadas» ou abandonadas e que son aplicadas con máis dureza naqueles casos en que existe un xestor aínda activo. Deste xeito, os silvicultores rexeitan a imposición de restricións aos seus investimentos e, de maneira simultánea, increméntase o risco de abandono da xestión en casos actualmente activos. $\mathrm{O}$ reto preséntase en regular as parcelas deixadas en abandono, mobilizar aqueles territorios onde sexa prioritario facelo e intervir neles, e entender esas medidas, no canto de prexudiciais, como axudadoras e motivadoras do conxunto dos mellores xestores no territorio. 
Nun espazo forestal como o galego, tan extenso e complexo, as estratexias de mellora e ordenación dese espazo deben mudar a súa perspectiva. O experimentado fracaso da construción de arriba abaixo ten que deixar paso a unha construción moito máis precisa de abaixo arriba, facendo esforzos para ir acadando «o posible» co obxecto de ir «chegando», mediante a mellora continua, ao «bo».

Ninguén tentaría resolver un quebracabezas, aínda que poida ter unha guía de como quere que quede ao final, sen tomar atención das pezas e de como ir pouco a pouco encaixando e situando as que teña dispoñibles, reducindo os espazos de incerteza. E, alén diso, neste caso nin sequera estamos seguros de contarmos con todas as pezas necesarias, polo que teremos ademais que buscar como substituílas por outras que cumpran a súa función no conxunto.

Ao mesmo tempo, non hai que esquecer que unha parte da responsabilidade de evitar a reiteración de incendios catastróficos reside en decisións que cada compoñente da sociedade toma todos os días e que inflúen no territorio: onde e como se vive; que se consome; onde foi producido iso que se consome; se se está ou non disposto a pagar polo lecer que se desenvolve en áreas forestais, ou polo osíxeno ou a auga que producen; que se esixe aos representantes políticos; se se participa na comunidade de montes onde se reside; se se están buscando alternativas para pór en produción as parcelas forestais que se herdaron. Hai tarefa para todos antes dos incendios.

\section{CONCLUSIÓNS}

O agravamento percibido do patrón de incendios forestais ten a súa raíz na xestión da paisaxe, na escalada da continuidade e carga de combustible propiciada polo abandono das actividades rurais, intensificado polo cambio climático.

O estudo dos grandes incendios do 2017, especialmente os acontecidos en Portugal, mostra como conclusión a chegada da tipoloxía potencial de incendios de sexta xeración, letais para a poboación, os servizos de defensa contra incendios, as infraestruturas e os intereses da sociedade en xeral.

Os grandes incendios forestais que afectan extensas áreas homoxéneas nas que existe unha alta carga de combustible tras o abandono da agricultura e a silvicultura acaban retroalimentando o abandono e o risco de sufrir un novo grande incendio é maior. 
Para anticiparse ás situacións de perturbación causadas polo lume, a acción silvícola é fundamental e, en xeral, terá sempre unha certa compoñente preventiva no seu obxectivo de xestión e mellora das masas forestais.

O tipo de material combustible e as súas características físicas e químicas, a cantidade "carga» del, a súa superficie de exposición, o seu grao de compactidade e a súa distribución espacial nos planos horizontal e vertical son os factores que determinarán o comportamento do lume. Os combustibles son complexos en moi alto grao nas súas características e interaccións. En circunstancias normais, mesmo por riba da súa composición específica, a estrutura da masa é o principal condicionante da súa inflamabilidade a escala de poboamento forestal e paisaxe.

Basicamente, a aplicación da silvicultura preventiva pódese realizar en dous niveis territoriais: así, diferéncianse estratexias a escala local (parcela, monte ou grupo de montes) e a escala comarcal. As principais accións previstas pola silvicultura preventiva son actuacións sobre o combustible forestal, creación de descontinuidades na masa e nas infraestruturas lineais e prevención a escala comarcal, con modificación do combustible a escala de paisaxe.

En xeral, a prevención estrutural non segue unha política transversal, encarando o territorio como un todo, e adoita considerarse como a suma de accións, a escalas de xestión forestal, que son executadas por diferentes axentes e organismos. A pesar de poder ser eficaz nos casos máis habituais de incendios, esta falta de accións xeneralizadas en territorios máis amplos non permite unha adecuada defensa fronte aos grandes incendios forestais.

En Galicia, o territorio é o resultado de milleiros de anos de intervención humana. Actualmente as mudanzas prodúcense cunha grande intensidade e rapidez e, na maioría dos casos, sen integración entre elas. A expansión da denominada interface urbano-forestal, asociada á crecente dispersión do sistema de asentamentos e á progresión da vexetación natural, constitúe unha dinámica territorial preocupante.

Despois de máis de trinta anos de autonomía galega, a ordenación do territorio mantense como unha materia pendente. A manifesta dificultade amosada durante décadas para planificar o crecemento ordenado do urbanismo galego fai dubidar de que os instrumentos inspirados na mesma filosofía, a da planificación urbanística, sexan axeitados para traballar na ordenación do espazo rural e, en particular, do forestal. 
A propia «delimitación» do que se entende por espazo forestal no territorio non é un asunto trivial, nin sequera desde o punto de vista xurídico.

Por outra banda, o mesmo concepto de ordenación forestal veu experimentando un profundo cambio, grazas á experiencia acumulada de máis dun século desde a súa concepción e aplicación, con discutible grao de implantación. No que atinxe á xestión de propietarios forestais particulares, permaneceu durante o último século á marxe dela, por complexa e por afastada da ortodoxia da ordenación de montes.

Noutros países, en xeral, a planificación en montes privados enténdese como unha ferramenta de axuda ao silvicultor na que se pon en xogo a información que producen ou posúen os organismos públicos forestais. Os traballos de inventario que debe sufragar o propietario forestal dependen do seu mero interese en obter máis coñecementos e cuantificacións sobre o estado do seu monte. Desde o punto de vista do interese público, búscase que os plans sirvan para que os propietarios forestais coñezan e apliquen as restricións legais sobre áreas de conservación e demais elementos.

Neste sentido, o desafío principal é entender, prioritariamente, a "ordenación forestal» como a organización no espazo e no tempo da silvicultura, e que pase a ser sempre un conxunto de compromisos bidireccionais, entre a propiedade e a sociedade (representada, na maior parte das ocasións, pola Administración competente), ao respecto das liñas xerais de xestión que desenvolver nunha propiedade específica.

Deste xeito, é en extremo interesante o camiño emprendido pola Lei 7/2012, do 28 de xuño, de montes de Galicia e, con posterioridade, o Decreto 52/2014, do 16 de abril, polo que se regulan as instrucións xerais de ordenación e de xestión de montes de Galicia.

Como a maior parte das unidades de xestión forestal posúen un escaso tamaño e algunhas das principais medidas preventivas de incendios forestais descritas en apartados anteriores han de deseñarse e executarse a unha escala de "paisaxe», unha escala interesante de traballo é aquela superior á da unidade de xestión e inferior á comarcal.

Todas estas disposicións apuntan ao decisivo papel que PPDCIFD e PORF deberían ter na execución de medidas preventivas en escalas superiores á da unidade de xestión forestal. A realidade, hoxe en día, non indica o mesmo. 
Non parece que esteamos carentes de ferramentas legais de regulación e planificación do espazo forestal, senón máis ben ao contrario. Así, todo apunta a unha excesiva proliferación normativa, de difícil encaixe e arrevesada xerarquía.

Cando se producen episodios graves de incendios, con frecuencia esquécese que os silvicultores e comunidades de montes son grandes afectados polos lumes e como tales merecen ser tratados.

Nun territorio maioritariamente privado, onde a xestión directa, ao contrario que noutras áreas xeográficas, non corresponde aos poderes públicos, a misión da política forestal é a de servir de marco e, á vez, de panca para posibilitar a mellora da xestión de miles de axentes, compatibilizándoa coa defensa do interese xeral.

A falta de rendibilidade de moitos modelos forestais e os cambios experimentados no mundo rural durante os últimos vinte anos levan consigo o incremento da superficie forestal infraxestionada ou mesmo abandonada. Isto, ademais das obvias consecuencias desde o punto de vista produtivo, incrementa o risco de maiores e máis graves incendios, sobre todo nas áreas de interface urbano-forestal.

Tendo en conta a modesta rendibilidade de moitas das alternativas forestais e a non-profesionalidade da maior parte dos silvicultores, non é estraño que os procesos de incremento da presión normativa ou impositiva se traduzan, ao contrario do que pretenden, en incrementos da superficie infraxestionada ou abandonada.

No proceso de abandono, gradualmente vaise pasando por diversos estados intermedios, até chegar ao denominado abandono irreversible, no cal territorio e propietario perden calquera vencello.

Cando falamos de silvicultura preventiva a escala de paisaxe, debería empregarse a intervención pública sobre as áreas de abandono irreversible para desenvolver estratexias preventivas.

Do mesmo xeito, para frear o proceso de abandono no territorio, antes (ou ademais) da toma de medidas ambiciosas para a reversión, debería evitarse que o proceso seguise producíndose.

Cando se analizan os silvicultores activos, non é factible establecer de xeito nidio unha liña que separe a xestión forestal «correcta» da que non o é. A multiplicidade de posibles itinerarios silvícolas e os distintos valores que chegan a alcanzar as variables que poderían representar esa xestión obrigan a considerar a 
«bondade» da xestión forestal como un continuo, no cal normalmente é fácil distinguir os extremos, pero a gradación intermedia é, en moitos aspectos, sutil. Semella clave a segmentación dos xestores para a aplicación de medidas distintas. O emprego segmentado dun abano de accións (desde as medidas coercitivas aos incentivos, pasando pola extensión forestal) tería como obxectivo mellorar, de xeito constante, a xestión forestal en Galicia e, con isto, a prevención dos incendios que, en número, extensión e intensidade, poidan supoñer danos e riscos como os vividos en 2017.

Unha parte da responsabilidade de evitar a reiteración de incendios catastróficos reside en decisións que cada compoñente da sociedade toma todos os días e que inflúen no territorio: onde e como se vive; que se consome; onde foi producido iso que se consome; se se está ou non disposto a pagar polo lecer que se desenvolve en áreas forestais, ou polo osíxeno ou a auga que producen; que se esixe aos representantes políticos; se se participa na comunidade de montes onde se reside; se se están buscando alternativas para pór en produción as parcelas forestais que se herdaron. Hai tarefa para todos antes dos incendios. 


\section{REFERENCIAS BIBLIOGRÁFICAS}

Ávalos, I. (2017): Ejemplo de gestión de un patrimonio rural familiar según la Ley 7/2012 de Montes de Galicia, traballo de fin de grao inédito (dir. J. Picos), Escola de Enxeñaría Forestal de Pontevedra (Universidade de Vigo).

CASTELlnou, MarC / ANTONI Rifà (2007): «El modelo de extinción de incendios forestales catalán», en IV Conferencia Internacional sobre Incendios Forestales (Wildfire 2007), Sevilla (España).

Castellnou, Marc / Marta Miralles (2008): "Generaciones de incendios: herramienta de clasificación del riesgo y de las necesidades estratégicas en su gestión», DGPEIS, comunicación interna.

Chas-Amil, María L. / Julia Touza / Eduardo García-Martínez (2013): «Forest fires in the wildland-urban interface: A spatial analysis of forest fragmentation and human impacts», Applied Geography, 43, 127-137.

Confemadera Hábitat Galicia (2014): Informe de resultados 2013, [Santiago de Compostela].

Corbelle Rico, Eduardo / Rafael CRECEnTE MASEDA (2008): «El abandono de tierras: concepto teórico y consecuencias", Revista Galega de Economia, 17:2, 1-15.

Corbelle Rico, Eduardo / Rafael Crecente Maseda (2014): «Urbanización, forestación y abandono. Cambios recientes en el paisaje de Galicia, 1985-2005", Revista Galega de Economía, 23:1, 35-52.

EID, Tron (2006): «Forest Planning in Private Forests - Norway», en Tuula Nuutinen / Leena Kärkkäinen / Leena Kettunen (eds.), Forest Planning in Private Forests in Finland, Iceland, Norway, Scotland and Sweden. Proceedings of ELAV seminar, 23-24 March 2006, Koli, Finland. Working papers of the Finnish Forest Research Institute, 38, 36-41.

FAO (Organización de las Naciones Unidas para la Alimentación y la Agricultura) (1996): Informe de la $5^{a}$ Conferencia Regional para Europa, Sevilla (España), 5-11 de octubre de 1966, Roma.

FARRIOL I ALMIRALL, Ricard (2008): «Instrumentos y métodos de planificación forestal en montes privados de Catalunya: los planes técnicos de gestión y mejora forestal», Cuadernos de la Sociedad Española de Ciencias Forestales, 27: «Actas de la Reunión sobre ordenación por rodales: experiencias y aplicación», $35-42$.

FERNANDES, Paulo M. (2009): «Fuel management and fuel treatments: 1. Introduction: background and rationale», Forest fires: impacts and post-fire management, 13-18 April 2009, Antalya, Turkey.

Fernandes, Paulo M. / Tiago Monteiro-Henriques / Nuno Guiomar / Carlos Loureiro / Ana M. G. BARros (2016): «Bottom-Up Variables Govern Large-Fire Size in Portugal», Ecosystems, 19:8, 1362-1375.

GARITACELAYA SALDISE, Jesús (2008): «La sorprendente historia de cómo se disiparon y desvanecieron los métodos de ordenación de montes", Cuadernos de la Sociedad Española de Ciencias Forestales, 27: "Actas de la Reunión sobre ordenación por rodales: experiencias y aplicación», 95-102.

GONDAR PORTASANY, Marcial (2007): «Territorio e identidade: proposta para unha nova filosofía dos parques empresariais", Foro do Instituto de Estudos das Identidades Territorio, paisaxe e identidade, Santiago de Compostela, Museo do Pobo Galego, 28-36.

González Molina, José María / Miriam Piqué Nicolau / Pau Vericat Grau (2006): Manual de ordenación por rodales: gestión multifuncional de los espacios forestales, Solsona, Centre Tecnològic Forestal de Catalunya. 
LÓPEZ IgLeSIAS, Edelmiro (2018): «Desestruturación do medio rural e desorde do territorio: o pano de fondo do problema dos incendios forestais en Galicia», Coloquio Galaico-Portugués sobre Incendios Forestais: Unha nova xeración de lumes?, Santiago de Compostela, Consello da Cultura Galega.

MAdrigal, Alberto (1998): «Problemática de la ordenación de masas artificiales en España», Cuadernos de la Sociedad Española de Ciencias Forestales, 6: «II Reunión sobre Ordenación de Montes», 13-20.

NuUtinen, Tuula (2006): «Forest Planning in Private Forests in Finland», en Tuula Nuutinen / Leena Kärkkäinen / Leena Kettunen (eds.), Forest Planning in Private Forests in Finland, Iceland, Norway, Scotland and Sweden. Proceedings of ELAV seminar, 23-24 March 2006, Koli, Finland. Working papers of the Finnish Forest Research Institute, 38, 28-31.

Oliveira, Emanuel (2016): La Prevención a la Escala del Paisaje para hacer frente a los Grandes Incendios Forestales. Análisis en el Alto Minho. Portugal, traballo de fin de mestrado (dir. Rosa Planelles), ETSI Montes, Forestal y del Medio Natural (Universidad Politécnica de Madrid).

PICOS MARTín, Juan (2015): O sector forestal en Galicia: problemática actual e perspectivas futuras, Documento 10/2015, Foro Económico de Galicia, s. 1 .

Picos Martín, Juan / Marc Castellnou Ribau / António Joaquim Salgueiro Rocha da Silva (2018): Cooperación transfronteriza en la prevención y extinción de incendios forestales en el Eixo Atlántico, Eixo Atlántico do Noroeste Peninsular, s. 1. (Cuadernos de Cooperación del Eixo Atlántico).

PIcos, Juan (coord.) (2018): La Cadena Forestal-Madera de Galicia 2017, Axencia Galega da Industria Forestal, Consellería de Economía e Industria, Xunta de Galicia / Universidade de Vigo.

Pyne, Stephen J. / Patricia L. ANDREWs / Richard D. LAVEN ( $\left.{ }^{2} 1996\right)$ : Introduction to Wildland Fire, New York, NY, John Wiley and Sons.

Rojo, Alberto / Santos G. Arenas / Guillermo Riesco (1998): «Ordenación de montes en Galicia», Cuadernos de la Sociedad Española de Ciencias Forestales, 6: «II Reunión sobre Ordenación de Montes», 177-189.

SAURA MARTínez DE TODA, Santiago (2009): «Del rodal al paisaje: un cambio de escala, nuevas perspectivas para la planificación y ordenación forestal», 50 Congreso Forestal Español: Montes y sociedad: Saber qué hacer, Ávila, 21-25 de septiembre, Sociedad Española de Ciencias Forestales / Junta de Castilla y León.

Sociedad Española de Ciencias Forestales (SECF) (2008): «Conclusiones de la reunión del grupo de trabajo de ordenación de montes de la Sociedad Española de Ciencias Forestales, realizada en Solsona, en los días 28, 29 y 30 de noviembre de 2007», Cuadernos de la Sociedad Española de Ciencias Forestales, 27: «Actas de la Reunión sobre ordenación por rodales: experiencias y aplicación», 149-150.

VÉLEZ, Ricardo (coord.) (2000): La defensa contra incendios forestales: fundamentos y experiencias, Madrid, McGraw-Hill.

Wilhelmsson, Erik (2006): «Forest Management Planning for Private Forest Owners in Sweden», en Tuula Nuutinen / Leena Kärkkäinen / Leena Kettunen (eds.), Forest Planning in Private Forests in Finland, Iceland, Norway, Scotland and Sweden. Proceedings of ELAV seminar, 23-24 March 2006, Koli, Finland. Working papers of the Finnish Forest Research Institute, 38, 52-60. 
LUMES NA INTERFACE

URBANO-FLORESTAL

\section{Luciano Lourenço}

Departamento de Geografia, NICIF, CEGOT e RISCOS

Universidade de Coimbra 



\section{INTRODUÇÃO}

De acordo com os dados provisórios disponibilizados pelo Instituto da Conservação da Natureza e das Florestas (ICNF 2017), no ano de 2017 e até ao dia 31 de outubro arderam 442418 ha de mato e floresta em Portugal continental, o que corresponde à maior área queimada num único ano, pelo que 2017 passou a deter o recorde da maior área ardida em Portugal continental num só ano, uma vez que superou em 16579 ha o fatídico ano de 2003, que detinha esse malogrado recorde.

Como se isso já não fosse destaque suficiente, no ano de 2017 bateram-se ainda outros recordes, dado que pela primeira vez se registaram:

(i) incêndios florestais com mais de 30000 ha, em número de três, tendo um destes sido superior a 40000 ha, com base nos dados provisórios;

(ii) mais de 50000 ha de área queimada no mês de junho;

(iii) mais de 220000 ha de área ardida no mês de outubro;

(iv) dois dias verdadeiramente excepcionais, em termos de condições meteorológicas e, também, em valor de área queimada: 17 de junho e 15 de outubro;

(v) 116 vidas perdidas em resultado de incêndios florestais, na sequência dos registados no mês junho (67 mortes) e em outubro (49 vítimas fatais).

Tratou-se de um ano verdadeiramente excepcional no que aos grandes incêndios florestais diz respeito, uma vez que além dos anteriormente referidos, se registaram ainda mais seis grandes incêndios: dois com dimensão superior a 25000 ha, três com mais de 15000 ha e um com mais de 10000 ha (ICNF 2017).

$\mathrm{Na}$ sua rápida progressão, qualquer deles encontrou um grande número de aldeias, cujas interfaces urbano-florestais não se encontravam geridas de forma a evitar a propagação e, por outro lado, a facilitar o combate aos incêndios, facto 
que, por não ter sido antecipadamente prevenido, apesar da existência de legislação que desde 2004 a isso obrigava (Decreto-Lei n. ${ }^{\circ}$ 156/2004, de 30 de junho), contribuiu para o elevado número de mortos que se veio a contabilizar.

Como foi relatado pela comunicação social, Portugal assistiu incrédulo e em choque aos incêndios florestais de 2017, que foram a maior catástrofe nacional, em número de mortos, desde as cheias do rio Trancão, um afluente do Tejo, situado a Norte de Lisboa, ocorridas no ano de 1967, havia precisamente cinquenta anos, as quais registaram um número indeterminado de mortos, mas que foi superior a 400 .

As explicações que apontamos para o sucedido neste ano de 2017 não resultam de um trabalho de investigação inédito, como os realizados pela CTI (2017 e 2018) ou outros, pois não têm esse objetivo específico, mas apenas permitem alertar para algumas situações que acompanhámos ao longo dos últimos trinta anos e que ajudam a enquadrar o assunto, ajudando a compreender a forma como se abandonou o interior e se deixou evoluir a floresta, ao ponto dos incêndios florestais poderem alcançar tamanhas proporções.

\section{A EVOLUÇÃO DOS INCÊNDIOS FLORESTAIS EM PORTUGAL CONTINENTAL}

O aumento da área queimada por incêndios florestais em Portugal Continental costuma associar-se à revolução do 24 de abril de 1974, uma vez que nesse verão se registaram alguns violentos incêndios e que voltaram a repetir-se no ano seguinte, devido à existência de verões «quentes» não só do ponto de vista meteorológico, mas também e sobretudo o segundo, na perspetiva política. Depois, nos dois anos subsequentes, os verôes foram meteorologicamente frescos e, por isso, os valores da área ardida voltaram a ser reduzidos.

Todavia, as transformaçóes que então se faziam sentir na sociedade portuguesa e que se incentivaram a partir dessa revolução, contribuíram para um conjunto de profundas alterações que se foram materializando, algumas delas com importantes consequências a nível do uso do solo. Com efeito, muitas áreas agrícolas foram abandonadas e, paulatinamente, foram-se transformando em espaços florestais, que, por sua vez, também foram ficando entregues a si próprios, tendo-se 
criado um ambiente propício ao desenvolvimento de incêndios, que aumentaram muito de número, nos dois últimos anos da década de 70, do século passado (fig. 1), quando as áreas ardidas também voltaram a ter valores semelhante aos dos anos de 1974 e 75 (fig. 2).

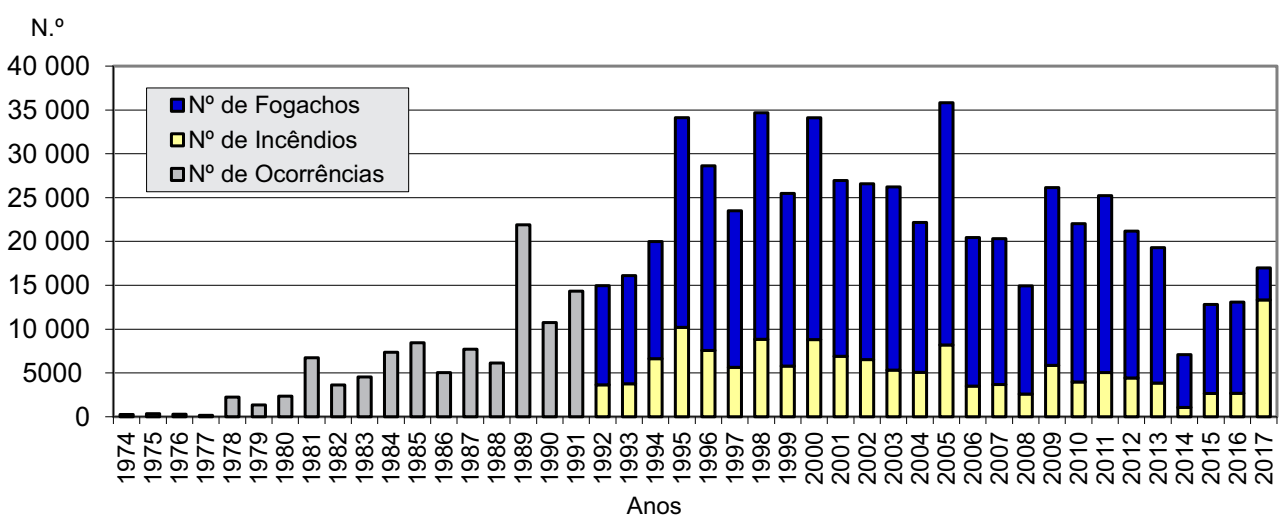

Fig. 1. Evolução anual do número de ocorrências de incêndios florestais em Portugal continental (Fonte dos dados: ICNF)

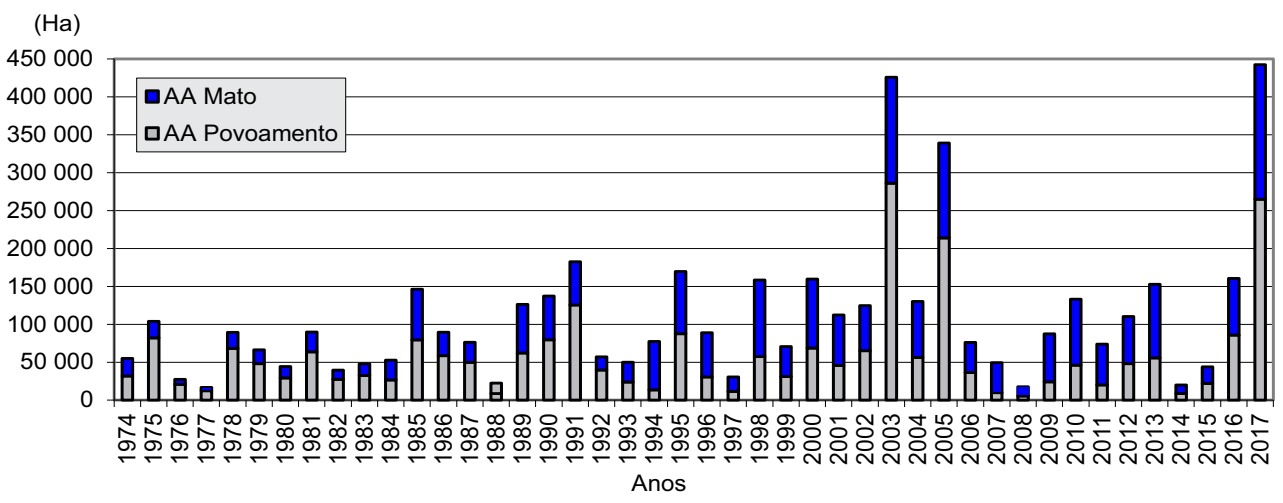

Fig. 2. Evolução anual da área queimada por incêndios florestais em Portugal continental (Fonte dos dados: ICNF)

Ao tempo, o aumento destes valores, relativamente ao período anterior a 1974, foi considerado muito grave e como tivesse continuado no ano seguinte, de 1980, essa situação exigiu a tomada de medidas legislativas, em termos da «organização da defesa do património florestal do continente contra o flagelo dos 
incêndios», que se materializaram na publicação de uma série de diplomas legais, designadamente: Decreto-Lei n. ${ }^{\circ}$ 327/80, de 26 de Agosto, que providenciou quanto à prevenção e detecção dos incêndios florestais; Lei n. ${ }^{\circ}$ 10/81, de 10 de Julho, que ratificou, com emendas, o Decreto-Lei n. ${ }^{\circ} 327 / 80$, de 26 de Agosto, publicando seguidamente a nova redação do Decreto-Lei n. ${ }^{\circ}$ 327/80; e Decreto Regulamentar n. ${ }^{\circ}$ 55/81, de 18 de Dezembro, que regulamentou a defesa do património florestal.

Ainda que algumas destas medidas legislativas não tenham sido bem aceites, como foi o caso da passagem do combate aos incêndios para os bombeiros, uma vez que, até então, ele era efetuado pelas brigadas florestais, dos designados «Serviços Florestais». Apesar de, aparentemente, essas medidas terem dado algum resultado a curto prazo, uma vez que nos anos imediatos, de 1982, 1983 e 1984, se observou alguma contenção nas áreas ardidas, já o número de ocorrências manteve a tendência de crescimento, com um máximo até muito acima dessa tendência, em 1989.

Mais tarde, um novo máximo em 1995 deu inicio a um período com um impressionante número anual de ocorrências, sempre superior a 20 000, e que se estendeu por mais de uma década, até 2005 (fig. 1). Este período não só registou o valor máximo de ocorrências desde que há registos, 35823 em 2005, ano que também obteve o segundo lugar em termos do valor da área ardida até então registado e cujo valor máximo (425839 ha) tinha acontecido precisamente dois anos antes, em 2003 (fig. 2).

Aliás, foi na sequência dos incêndios verificados no verão desse ano de 2003 que saiu o mais importante pacote legislativo português na área da defesa da floresta contra incêndios.

De entre os vários diplomas publicados, referimos a Resolução do Conselho de Ministros n. ${ }^{\circ}$ 178/2003, de 17 de novembro, publicada ainda em 2003, que aprovou as grandes linhas orientadoras da Reforma Estrutural do Sector Florestal (RESF): (i) novo modelo orgânico para o sector das florestas; (ii) reordenamento e gestão florestal; (iii) financiamento e fiscalidade; (iv) reestruturação do sistema de defesa contra incêndios; (v) reflorestação das áreas ardidas.

Para dar sequência e implementar essas linhas orientadoras, de entre os vários diplomas publicados no ano seguinte, em 2004, mencionamos, por ordem de publicação, alguns dos mais significativos: 
(i) Decreto-Lei n. ${ }^{\circ}$ 63/2004, de 22 de março, que criou o FFP, Fundo Florestal Permanente.

(ii) Decreto-Lei n.o 80/2004, de 10 de abril, que criou a DGRF, Direção Geral dos Recursos Florestais, com as funçôes de autoridade florestal nacional.

(iii) Decreto Regulamentar n. ${ }^{\circ}$ 5/2004, de 21 de abril, que criou a APIF, Agência para a Prevenção dos Incêndios Florestais.

(iv) Lei n. ${ }^{\circ}$ 14/2004, de 8 de maio, que criou as Comissóes Municipais de Defesa da Floresta contra Incêndios.

(v) Decreto-Lei n. ${ }^{\circ}$ 156/2004, de 30 de junho, que estabeleceu as medidas e ações a desenvolver no âmbito do Sistema Nacional de Prevenção e Proteção da Floresta Contra Incêndios.

Entretanto, na sequência da mudança de governo, ocorrida a 12 de março de

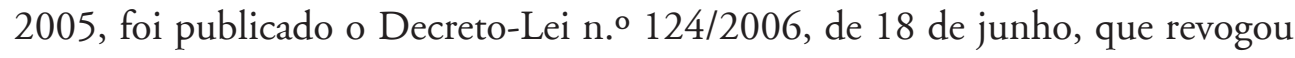
o anterior Decreto-Lei n. ${ }^{\circ}$ 156/2004, de 30 de junho, e estabeleceu as medidas e ações a desenvolver no âmbito do SNDFCI - Sistema Nacional de Defesa da Floresta Contra Incêndios.

Depois de alguma acalmia legislativa, com a entrada de um novo governo, em 26 de novembro de 2015, sentiu-se necessidade de, decorrida uma dúzia de anos, se promover uma nova «reforma florestal», sem que a anterior tenha sido devidamente implementada e sem que, anteriormente, este novo governo tenha tomado medidas com vista à avaliação das causas que impediram a sua concretização e materialização no território.

Como, politicamente, a produção de legislação deixa uma marca mais visível do que a sua aplicação, provavelmente será essa a explicação para um maior empenho na produção de legislação do que na sua aplicação e na manutenção do seu cumprimento.

$\mathrm{Na}$ verdade, a nova proposta de reforma era constituída por 12 diplomas, dos quais um foi rejeitado pela Assembleia da República, referente ao Banco Nacional de Terras, tendo os restantes 11 sido aprovados, a saber:

(i) Equipas de sapadores florestais no território continental.

(ii) Comissão para os Mercados e Produtos Florestais (CMPF).

(iii) Programa Nacional de Fogo Controlado (PNFC).

(iv) Novas centrais de biomassa florestal. 
(v) Planos Regionais de Ordenamento Florestal (PROF).

(vi) Reconhecimento das entidades de gestão florestal.

(vii) Zonas de Intervenção Florestal (ZIF).

(viii) Sistema de Defesa da Floresta contra Incêndios (SDFCI).

(ix) Sistema de informação cadastral simplificada.

(x) Regime jurídico de arborização e rearborização.

(xi) Benefícios fiscais para entidades de gestão florestal.

Talvez porque acompanhámos as tentativas de implementação das diferentes medidas legislativas aprovadas anteriormente a estas, entendemos que seria preferível fazer aplicar a legislação que se encontrava em vigor, com a eventual introdução de alterações pontuais, sempre que tal fosse considerado necessário, em vez de tentar resolver os problemas com produção de nova legislação que, muitas vezes, pouco tem de inovador em relação à existente. Esperemos que desta vez seja diferente e que esta venha a ser aplicada e tenha êxito, quer na redução do número de ignições, quer na diminuição da área queimada!

\section{OS INCÊNDIOS NAS INTERFACES URBANO-FLORESTAIS PORTUGUESAS}

Não pretendendo discutir se o conceito de interface urbano-florestal será mais adequado ao tema do que o de interface urbano-rural, diremos apenas que optámos pelo de urbano-florestal, pelo facto de que os incêndios agrícolas que, porventura, possam entrar em contacto com áreas urbanas, à partida serão mais fácies de combater, por serem menos violentos, do que aqueles que lavram em áreas com aptidão florestal, estejam elas ocupadas por floresta ou por mato, razão pela qual nos parece que a designação urbano-florestal é mais adequada para o tipo das interfaces em apreço.

Assim, entendemos a interface urbano-florestal num sentido abrangente, como sendo a área de contacto entre o espaço com potencial aptidão florestal, independentemente da sua atual ocupação (florestal, agrícola ou inculto), e o espaço edificado, dito urbano. Trata-se de uma área que pode ter problemas de delimitação, uma vez que se trata de um espaço com uma ocupação dinâmica, em resultado das diversas atividades que nela se desenvolvem e dos usos que the 
podem ser afetados, bem como do crescimento das áreas edificadas para os espaços agrícolas e florestais que as envolvem.

Ora, quando os incêndios florestais afetam estas interfaces, eles podem ser de dois tipos diferentes, consoante o sentido da sua progressão, ou seja: (i) tiveram início em áreas urbanas confinantes com espaços florestais ou com aptidão florestal nos quais, depois, passaram a desenvolver-se, ou (ii) tiveram início e lavraram em espaços florestais ou com aptidão florestal e que, posteriormente, atingiram áreas urbanas com eles confinantes.

Normalmente os primeiros são menos problemáticos do que os segundos, pelo facto dos sentidos de progressão serem contrários. Com efeito, enquanto que na primeira situação o sentido da progressão das chamas tende a afastá-las do edificado, uma vez que progride em direção à floresta, no segundo caso ocorre precisamente o contrário e, porque as chamas se dirigem no sentido do edificado, podem gerar-se situaçóes de grande violência, sobretudo quando os combustíveis existentes nas áreas de interface não foram convenientemente geridos, como sucedeu em muitas das situaçôes registadas em 2017.

Mas, será que os incêndios florestais em áreas de interface urbano-florestal foram um problema novo, que surgiu apenas em 2017? Não nos parece, como demonstraremos a seguir. Sendo assim, fará sentido questionar então, porque é que os incêndios nas interfaces urbano-florestais ganharam acuidade e atualidade? Certamente terá sido por terem passado a ser mais frequentes, a possuir maiores dimensóes e a causar maiores danos, incluindo a perda de vidas humanas.

Estes factos permitiram que, nos últimos anos, se lhes tenha dedicado mais atenção do que anteriormente sucedia e, sobretudo, que lhes tenha sido dado um enquadramento específico, dentro do conjunto dos incêndios florestais, o que terá despertado a atenção para os incêndios florestais que se desenvolvem neste contexto. De facto, ele é muito mais mediático e muito mais facilmente acessível aos meios de comunicação social do que os incêndios que lavram em áreas montanhosas, afastadas dos principais centros urbanos, o que também contribui para tornar estes incêndios em interfaces urbano-florestais muito mais apelativos e apetecíveis para diretos televisivos, ou para longas reportagens sobre os perniciosos efeitos dos incêndios, do que aqueles que lavram exclusivamente em áreas montanhosas de mato e alguma floresta.

Todavia, este incêndios não são tão recentes e, muito menos, só de agora, como, por vezes, alguns parece fazerem crer. 
2.1. Incêndios em interfaces urbano-florestais, anteriormente a abril de 1974

Como foi referido, nestes tempos recuados os incêndios florestais eram poucos e de pequena dimensão, o que não significa que, pontualmente, não se registasse um ou outro de maior dimensão e com consequências mais graves, como foi o caso do que ficou conhecido por Vale do Rio, que relatamos a seguir.

\subsubsection{1 - Vale do Rio (Figueiró dos Vinhos)}

O exemplo que escolhemos refere-se ao incêndio de 28 de agosto de 1961, quando duas aldeias do concelho de Figueiró dos Vinhos arderam por completo: Vale do Rio, onde foram destruídas 49 habitações (fot. 1), e Casalinho, que viu as 5 casas da pequena aldeia totalmente queimadas. Neste incêndio faleceram também duas pessoas, uma em Vale do Rio e, a outra, em Chavelho (Fernandes 2013).

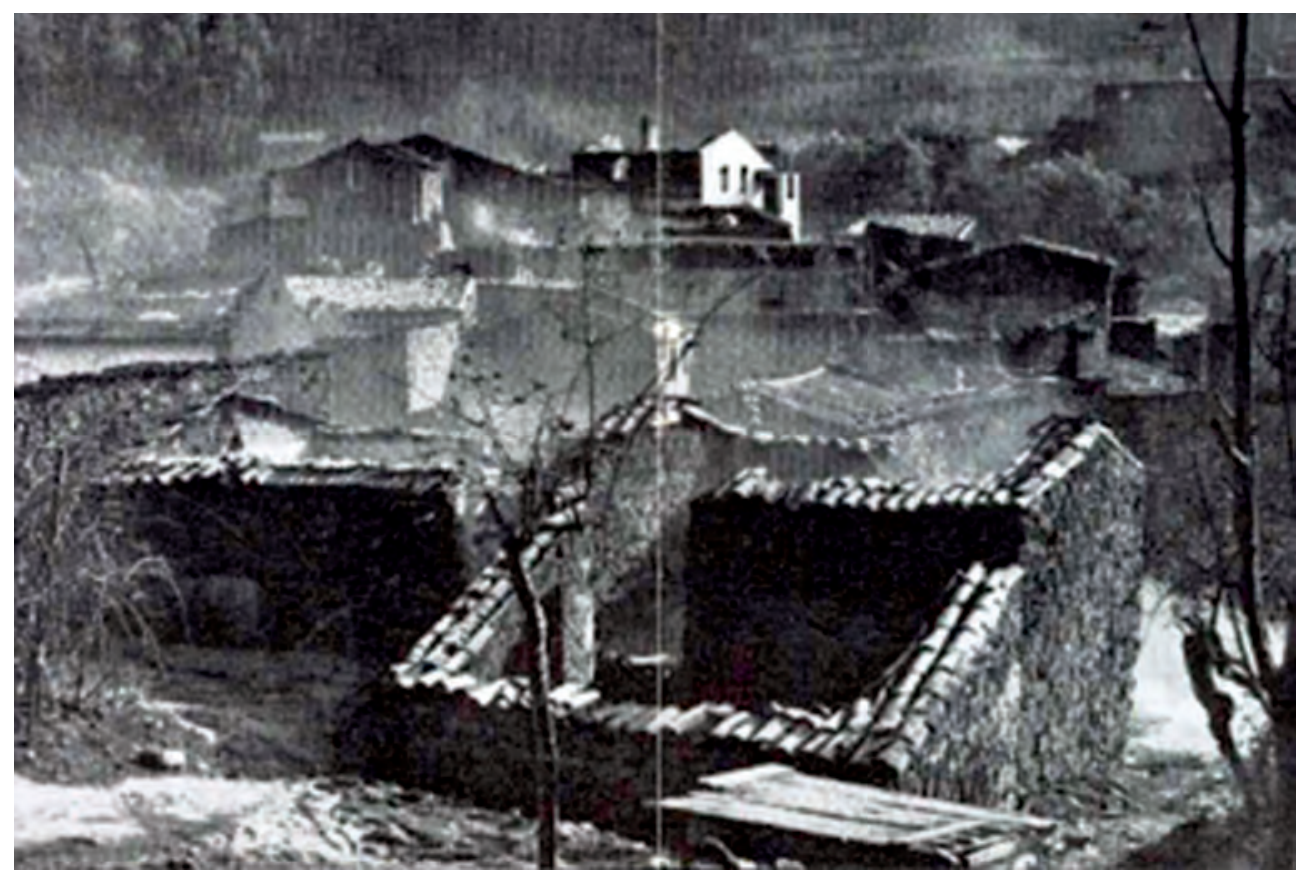

Fot. 1. Aspeto da destruição em Vale do Rio depois do incêndio de agosto de 1961

(Fonte: Fernandes 2013) 
Depois disso, a aldeia do Vale do Rio foi reconstruída, incluindo a abertura de uma estrada de acesso que, ao tempo do incêndio, não existia e, apesar das dificuldades inerentes a essa reconstrução, quando comparadas com as facilidades técnicas hoje existentes, a reconstrução da aldeia de Vale do Rio foi inaugurada cerca de três anos depois, no dia 24 de outubro de 1964, pelo então presidente da República, Almirante Américo Tomás.

Entretanto, após a reconstrução, a aldeia foi perdendo habitantes e parou no tempo. A estrada principal, de acesso à aldeia e que termina na capela, foi asfaltada, mas pouco mudou em relação a 1964, ano em que foi inaugurada.

A capela mantém-se cuidada nos dias de hoje, e foi nela que, em 14 de julho de 1989, se albergou toda a população de Vale do Rio quando, mais uma vez, a aldeia ficou cercada pelo lume e foram destruídas 8 habitações. Depois disso, voltou a estar rodeada pelas chamas, designadamente em 20 de julho de 2005, quando ardeu a escola primária que tinha resistido ao incêndio de 1989 e, de novo, no ano de 2017, a 18 de junho.

Com efeito, muito mudou em Portugal depois do início dos anos sessenta do século passado, quando ocorreu o incêndio. O surto de industrialização, sobretudo na margem sul do Tejo, e, mais tarde, a emigração para o Centro da Europa, particularmente para França, levaram a uma acentuada diminuição da população ativa nas regiōes do interior e ao colapso demográfico dessas regióes, que por sua vez originou o colapso do sistema agro-silvo-pastoril, vigente à época, o qual acabou por arrastar vastas regiōes para o colapso socioeconómico que, no conjunto, levaram à degradação dos espaços florestais.

De facto, o êxodo rural conduziu ao progressivo abandono dos campos agrícolas que, paulatinamente, se reconverteram em espaços florestais e que, por não serem geridos, ficaram abandonados e entregues a si próprios, favorecendo a continuidade horizontal e vertical das espécies, bem como o contínuo e progressivo aumento da carga combustível, o que, em caso de incêndio florestal, facilita a propagação das chamas e torna mais difícil o seu combate, razão pela qual não será de admirar que os incêndios tenham tendência para serem cada vez de maior dimensão, sendo também cada vez maior a área queimada num único incêndio. 


\subsection{Incêndios em interfaces urbano-florestais, após abril de 1974}

Portugal, depois da revolução de 25 de Abril de 1974, atravessou uma grave crise financeira, que foi acentuada tanto pela recessão da economia mundial como pela perda do mercado colonial, o que o obrigava a manter uma grande dependência externa. Foi nesse difícil contexto que Portugal se aproximou do mercado europeu, tendo feito o pedido de adesão à então CEE (Comunidade Económica Europeia) em 1977, o qual só se viria a realizar na década seguinte, quase uma dezena de anos depois, dado que só se concretizou em 1986, juntamente com a Espanha. Assim, não será de admirar que os incêndios em áreas de interface, ocorridos durante este período, tenham tido alguns problemas de reconstrução das habitações destruídas, dado que procuraram encontrar financiamento no novo quadro da integração europeia.

A título de exemplo, para comparação com o sucedido em Vale do Rio, referimos outra aldeia, de nome Rabigordo, do vizinho concelho de Pedrógão Grande, que também foi completamente destruída por um incêndio florestal e, posteriormente, se voltou a ver rodada por lume, nomeadamente também no ano de 2017.

\subsubsection{3 - Rabigordo (Pedrógão Grande)}

A pequena aldeia do Rabigordo, com apenas dez casas, seis de habitação e quatro de arrecadação, foi deixada em ruinas pelo incêndio florestal de 23 de setembro de 1983 e, anos mais tarde, voltou a ver-se rodeada pelas chamas, sendo a última vez no ano de 2017, como aconteceu em Vale do Rio.

A grande diferença entre as duas primeiras situações destas aldeias diz respeito ao tempo da reconstrução após os incêndios. Como vimos, em regime de ditadura, Vale do Rio foi recuperado em três anos, ao passo que o Rabigordo, em regime democrático e já depois da entrada na CEE, atual União Europeia, viu a sua reconstrução demorar um período de tempo três vezes maior, ou seja, nove anos.

Com efeito, uma rápida análise à fita do tempo mostra que:

- A aldeia foi destruída em setembro de 1983.

- Nove meses depois, em junho de 1984, foi feito o levantamento topográfico das ruínas da aldeia. 
- Dois anos após o incêndio, em setembro e outubro de 1985, a Câmara Municipal de Pedrógão Grande procedeu à demolição das ruínas das casas.

- Nesse mesmo ano de 1985, o Gabinete de Apoio Técnico de Figueiró dos Vinhos iniciou a elaboração do projeto para a reconstrução da aldeia de Rabigordo.

- O projeto foi entregue no ano seguinte, em outubro de 1986, ou seja, três anos depois do incêndio, quando, em Vale do Rio, decorrido esse tempo, as casas já tinham sido reconstruídas.

- Nove meses depois, em julho de 1987, deu-se inicio às obras de reedificação.

- Decorridos dois anos e alguns meses, as obras pararam em finais de 1989 e foram interrompidas por falta de financiamento.

- No ano seguinte, em fevereiro de 1990 houve uma nova avaliação e elaboração do respetivo orçamento, mas as obras continuaram paradas.

- Em junho de 1991, comprovámos o estado de abandono (fot. 2) em que se encontravam (Lourenço 2009).

- No mês seguinte, julho de 1991, a Câmara Municipal de Pedrógão Grande procedeu ao pedido de propostas para o acabamento das obras.

- Em outubro de 1991 foi estabelecido um acordo com um empreiteiro para concluir as obras.

- Finalmente, em 1992, isto é, nove anos depois do incêndio florestal, deu-se a conclusão das obras.

Então, passados nove anos, tínhamos casas novas, bonitas, prontas para serem entregues aos proprietários. Mas, nove anos é muito tempo! Os antigos residentes perderam a ligação ao lugar e procuraram outras alternativas para viverem. Então para que servirão essas novas casas e o investimento que nelas foi feito? Duas dessas casas têm aspeto de nunca terem sido habitadas, existindo mato e silvas em volta delas, enquanto outras duas aparentam nem sequer terem terminado completamente as obras, e apenas duas são visitadas com alguma regularidade, mantendo os logradouros e o espaço envolvente limpos (Lourenço 2009). A aldeia tem um aspeto de abando, uma vez que habitualmente ninguém lá reside, havendo apenas alguns proprietários que a visitam ao fim de semana ou em férias, como tivemos oportunidade de confirmar, mais uma vez, depois dos incêndios de 2017. 


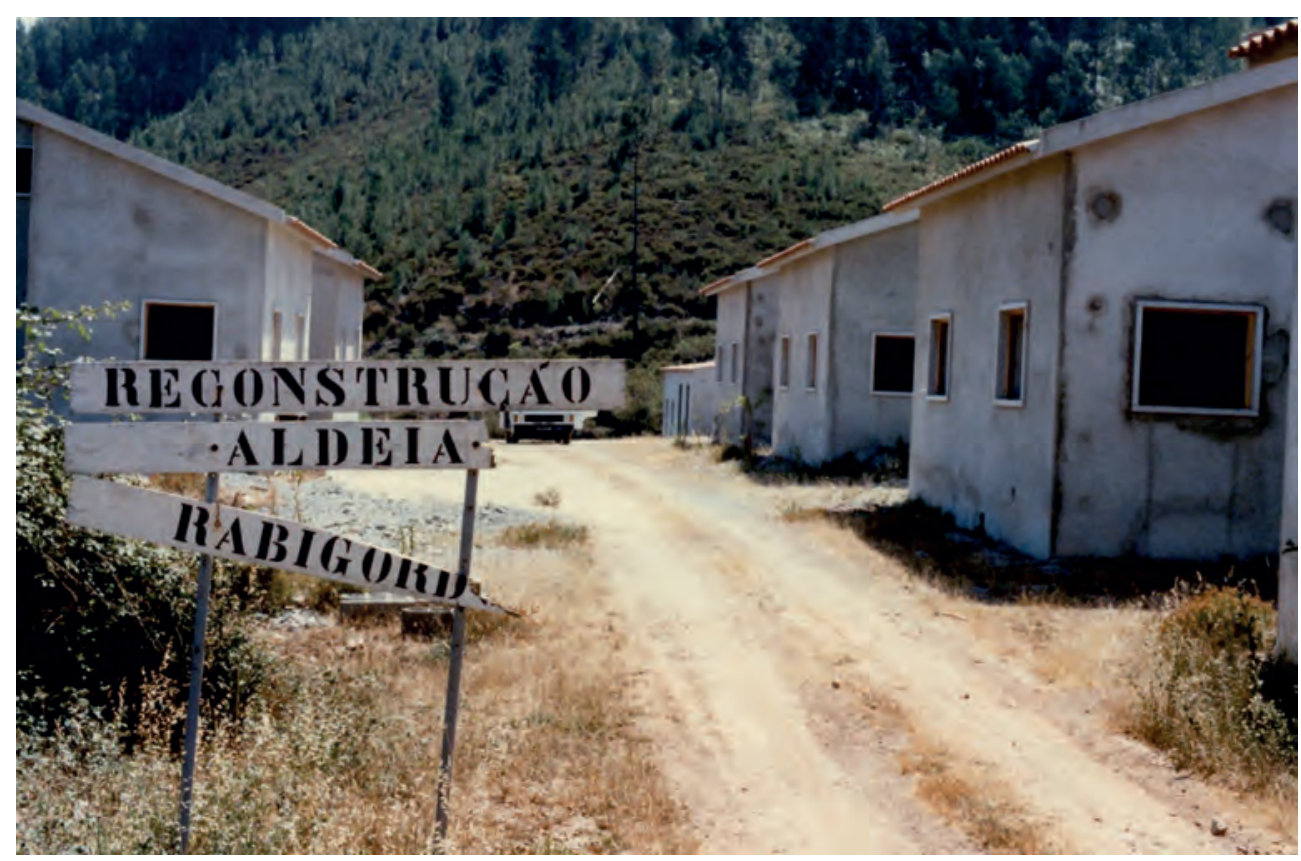

Fot. 2. Aspeto da fase de suspensão da reconstrução da pequena aldeia de Rabigordo (Fotografia de L. Lourenço, junho de 1991)

\subsubsection{O crescimento desordenado das periferias urbanas}

O estado em que se encontra a generalidade das interfaces urbano-florestais portuguesas é resultado do modo como elas foram evoluindo, constituindo um claro exemplo de: (i) em primeiro lugar, falta de ordenamento do território ou, talvez melhor, de respeito pelo cumprimento da legislação aplicável ao ordenamento do território; (ii) em segundo lugar, falta de planeamento urbano ou de cumprimento das normas impostas pelos planos diretores municipais; (iii) por último, falta de gestão florestal dos espaços confinantes com o edificado.

Com efeito, a evolução destas áreas fez-se, muitas vezes, a expensas da existência de um terreno próximo da área urbana, servido por uma estrada municipal ou caminho florestal, onde o proprietário construiu a sua residência. Depois, o vizinho também acabou por construir outra residência, as quais, por se situarem fora do perímetro urbano, não dispunham de infraestruturas (água, saneamento 
básico, energia elétrica, estrada asfaltada...). Posteriormente, nas eleições autárquicas seguintes, surgiam as promessas de que, a troco do voto, se resolveriam esses problemas e, assim, paulatinamente, as periferias foram evoluindo, quase sempre de forma desordenada e crescendo em direção aos espaços envolventes, de uso ou com aptidão florestal.

Por outro lado, a progressiva alteração das espécies florestais autóctones que, numa primeira fase, resultou da destruição massiva das moitas de carvalhos e dos soutos de castanheiros, que preenchiam as vertentes serranas e atapetavam os fundos dos vales, com o objetivo de produzir madeira que, entre outras finalidades, foi usada nas naus e caravelas da epopeia dos descobrimentos, na talha e cadeirais de mosteiros e igrejas, na construção civil, bem como na produção de lenha e carvão, tendo deixado escalvadas ou reduzidas a mato rasteiro muitas vertentes das serras.

Depois, a partir do segundo quartel do século passado, foi feito um grande esforço na arborização dos litorais e dos baldios serranos, sobretudo com pinheiro bravo (Pinus pinaster), tendo então ocorrido a primeira grande alteração, uma vez que as tradicionais espécies de folhosas, que quase desapareceram para dar lugar a mato, foram substituídas por resinosas, que chegaram a constituir a maior mancha contínua de pinheiro bravo da Europa.

Ora, com as alteraçôes culturais e socioeconómicas anteriormente referidas e que a sociedade foi sofrendo durante esse tempo e conduziram ao êxodo rural e ao consequente declínio da agricultura e das atividades silvo-pastoris, bem como ao abandono da gestão da floresta, pouco a pouco os incêndios florestais foram ganhando importância, em quantidade e em dimensão da área ardida, ao ponto de terem transformado a atividade florestal tradicional em algo pouco atrativo e a darem azo à proliferação de outra espécie florestal, de crescimento muito mais rápido, o eucalipto (Eucaliptus globulus). De facto, esta espécie apresenta diversas vantagens quando comparada com o pinheiro, razões que explicam o seu grande incremento e de que destacamos as seguintes:

(i) maior rentabilidade económica a curto prazo e replicada no tempo, dado que o seu crescimento, sendo mais rápido do que o do pinheiro, garante proveito económico num prazo mais curto e em maior número, já que, no mesmo período de tempo, o proprietário pode obter receita três ou mais vezes, enquanto que com o pinheiro só obterá uma no final do ciclo; 
(ii) menor probabilidade de ser queimado, dado que o seu tempo de desenvolvimento é bem mais curto, cerca de 3 ou 4 vezes menor, do que o do pinheiro;

(iii) capacidade de autorregeneração, no caso de vir a ser queimado, uma vez que rebenta por toiça, o que garante o seu desenvolvimento sem necessidade de investimento em novas plantações, ao contrário do que sucede nos pinhais jovens que, por não possuírem pinhas com sementes, os pinhões, não têm capacidade de se autorregenerar, obrigando a investimento em novas plantaçóes.

A referência a esta progressiva alteração de espécies não é despicienda, uma vez que o tipo de espécie florestal intervém no comportamento do fogo, fazendo com que o combate aos incêndios possa ser mais dificultado ou facilitado consoante a espécie florestal em presença. Como é sabido, os incêndios progridem mais violenta e rapidamente nos eucaliptais do que nos pinhais e, nestes, mais rapidamente do que nos soutos e carvalhais.

Como, na atualidade e em resultado desta evolução, a espécie dominante em grande parte das interfaces urbano-florestais é o eucalipto, tudo se tem vindo a conjugar favoravelmente para que, progressivamente, os incêndios tenham mais facilidade em chegar ao limite de vários tipos de infraestruturas inseridas em ambiente florestal, designadamente quando situadas nas periferias urbanas. Por outro lado, isso também ajuda a explicar não só porque é que tem havido um crescente aumento da dificuldade em combatê-los, mas também porque é que assumem crescente gravidade.

\subsubsection{5 e 2005 - Coimbra}

A periferia da cidade de Coimbra pode ser apontada como um exemplo da crescente dificuldade do combate a incêndios florestais em áreas de interface, em resultado das transformaçóes verificadas no espaço periurbano, que seguiu o modelo de evolução apresentado. De facto, com o crescimento da cidade para os espaços agro-florestais circundantes, os incêndios florestais passaram a penetrar facilmente no interior do perímetro urbano da cidade, como se demonstra através de dois exemplos de incêndios, distanciados entre si de dez anos.

O primeiro deles, diz respeito a dois incêndios que se desenvolveram entre 13 e 15 de agosto de 1995, que «chegaram mesmo a entrar dentro da cidade [...], 
gerando o pânico, por exemplo na Rua Brigadeiro Correia Cardoso (fot. 3), atirando para as primeiras páginas dos jornais $\mathrm{o}$ risco de incêndio florestal que, no presente [já se dizia há mais de vinte anos!], ameaça lugares e territórios de Coimbra» (Lourenço 1996).

O segundo exemplo refere-se a outro incêndio que, dez anos depois, entrou no concelho de Coimbra, por volta das $20 \mathrm{~h} 30$ do dia 21 de agosto de 2005, e que, entre outros locais, voltou a afetar a Rua Brigadeiro Correia Cardoso, onde arderam dois automóveis e um apartamento. Além desta rua, outras áreas situadas no interior do perímetro urbano da cidade de Coimbra foram particularmente afetadas, designadamente as situadas a nascente: Picoto dos Barbados, Tovins (de Cima, do Meio e de Baixo), Chão do Bispo,

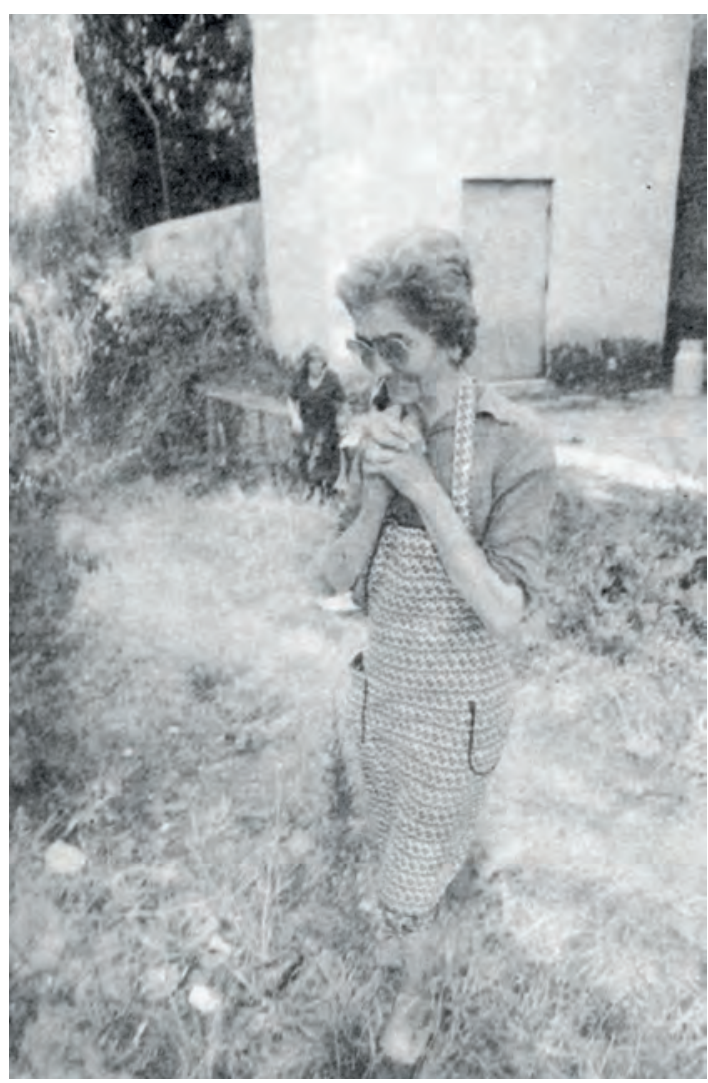

Fot. 3. Pormenor suficientemente expressivo da aflição vivida na interface urbano-florestal de Coimbra, face à aproximação do incêndio de agosto de 1995 (Fonte: Lourenço 1996. Fotografia de Paulo Rocha)

Quinta da Romeira, Areeiro, Pinhal de Marrocos e imediações do Polo II da Universidade. Várias localidades situadas nos arredores também foram rodeadas pelas chamas, tais como: Vale de Linhares, Rocha Nova, Serra da Rocha, Dianteiro, Carapinheira, Roxo, São Mamede e Rebordosa (Lourenço 2007).

Este incêndio afetou uma área de interface muito superior à queimada pelo anterior incêndio de 1995 e teve danos muito mais significativos. Todos quantos assistiram, impotentes, ao avanço avassalador das chamas e à sua penetração na cidade, não vão esquecer essa noite dantesca (fot. 4). 


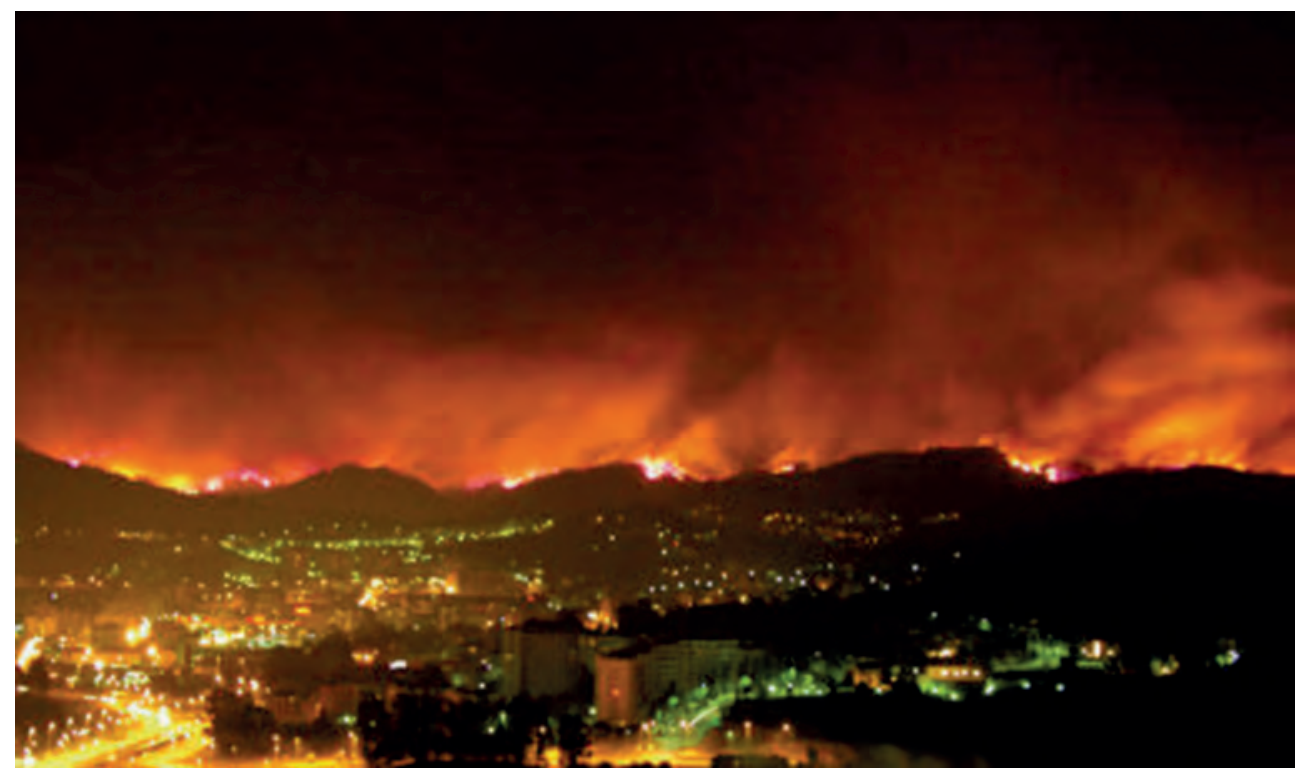

Fot. 4. Vista do avanço das chamas sobre a cidade de Coimbra, em primeiro plano, tomada desde Santa Clara (Fotografia: Celeste Moura)

Como, dez anos depois, tudo estava em condiçōes de voltar a arder de novo, interrogamo-nos sobre as consequências que teria um novo incêndio. Curiosamente, em 2017 os incêndios voltaram à área a sul do rio Mondego, precisamente onde teve início o incêndio que, em 2005, afetou a cidade. Felizmente, foram dominados antes de terem passado para norte do rio. E, talvez, porque os incêndios de 2017 foram trágicos, o Presidente da Câmara Municipal de Coimbra parece, finalmente, ter despertado para a importância da gestão do combustível nas áreas de interface, como noticiou o Diário de Coimbra, a 25 de março de 2018 (fig. 3), dia também marcado pelo falecimento de mais uma vítima dos incêndios de outubro do ano anterior. O Presidente da Câmara Municipal referiu que há mil hectares de terrenos municipais para limpar e mais 3 mil hectares de privados, ou seja, as faixas de gestão de combustível em áreas de interface urbano-florestal do município de Coimbra, ascendem a quatro mil hectares que carecem de intervenção urgente, para minimizar danos de eventuais incêndios florestais que possam ocorrer em 2018. 
Só é de lamentar que tenha sido necessária a morte de mais de uma centena de pessoas para que, finalmente, os autarcas comecem a assumir as responsabilidades que há muito lhes estão acometidas na gestão dos seus municípios. Queremos acreditar que será desta vez que vamos ver as faixas de gestão implantadas no território, pois esperamos que os autarcas não se fiquem apenas pelos levantamentos das áreas a intervencionar, mas que as mandem executar e que, nos anos seguintes, sejam capazes de assegurar a sua manutenção.

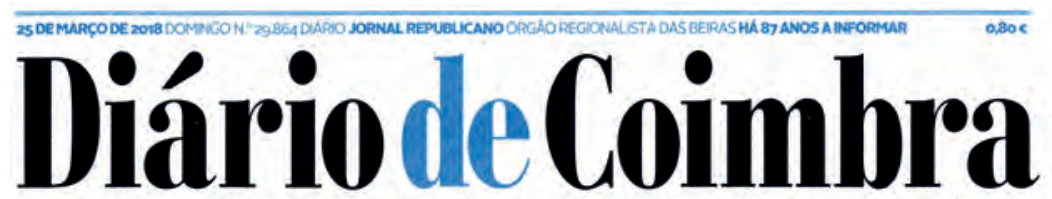

Fundador Adriano Lucas (1883-1950) | Dírector "in memoriam" Adriano Lucas (1925-2011) | Director Adriano Callé Lucas

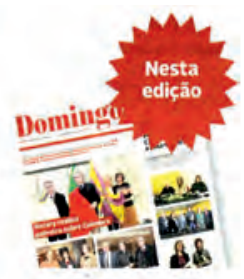

HÁ 4 MIL HECTARES

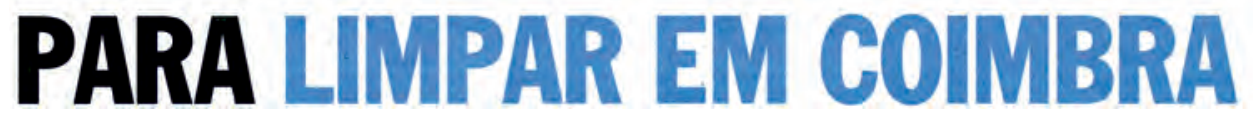

Fig. 3. Detalhe da primeira página do jornal, dando destaque às açôes de gestão de combustíveis nas faixas envolventes de edificado nas áreas de interface

(Fonte: Diário de Coimbra, 25 de março de 2018)

2.2.4. A chegada dos incêndios às periferias das vilas e aldeias inseridas em ambiente florestal e as prioridades do dispositivo de combate a incêndios florestais

De um modo geral, em meados do século passado, as aldeias estavam rodeadas por campos agrícolas. Por vezes, em parte do seu perímetro, confinavam também com sobreirais, cujo sub-bosque era meticulosamente gerido, razão pela qual os incêndios nessas interfaces eram extremamente raros.

Depois, com o abandono de alguns campos marginais, a floresta começou a aproximar-se das habitações, ao mesmo tempo que a expansão urbana começou a penetrar nos pinhais, fazendo com que, no final do século passado, os incêndios de interface tivessem começado a ter algum significado. 
Entretanto, a substituição do pinhal por eucaliptal fez com que os eucaliptos tivessem passado a confinar com as casas de habitação e, nestas circunstâncias, os incêndios de interface passaram a ser muito mais frequentes e violentos, como foi o caso do exemplo de Coimbra, antes apresentado.

Por outro lado, a predominância das plantaçôes de eucalipto muito contribui para uma maior quantidade de projeçôes de material incandescente, comparativamente com as registadas em incêndios de pinhal, bem como para uma maior distância dessas projeções, as quais podem originar novos focos de incêndios, a distâncias que são muito variáveis e que podem ser superiores a uma dezena de quilómetros.

Acresce que, com o decurso do tempo, devido às alterações no uso e ocupação do solo, as caraterísticas dos incêndios foram-se modificando, o que implicou a revisão das prioridades de atuação do dispositivo de combate, as quais também sofreram alterações, o que certamente teve consequências em termos do próprio comportamento dos incêndios.

Assim, em meados do século passado, a prioridade era claramente combater os incêndios na floresta, razão pela qual raramente eles atingiam áreas de interface.

Depois, com o abandono dos campos e o aumento da área florestal, os incêndios começaram a afetar com mais frequência áreas de interface e, a partir dessa altura, a defesa da floresta deixou de ser prioritária, tendo-se instituído como prioridade a defesa das pessoas e dos seus bens, o que, muitas vezes, teve como consequência deixar de combater os incêndios na floresta, que assim progrediam livremente, e esperá-los junto das habitações, para aí se fazer a respetiva defesa perimétrica.

À partida, este princípio parece estar correto, mas isso permite que os incêndios aumentem de intensidade durante a sua caminhada e cheguem com maior violência às habitações. Se, pelo contrário, fossem combatidos na floresta, chegariam com menos intensidade ou nem sequer chegariam se, entretanto, tivessem sido dominados e extintos. Se, por um lado, podemos compreender as razōes que terão estado na definição desta prioridade, por outra parte estamos convictos de que a sua aplicação nem sempre foi a mais correta, porventura por não ter sido suficientemente compreendida por quem teria de a aplicar, sobretudo porque a floresta foi deixando de ser considerada um bem para as pessoas, apesar de todas 
dela usufruírem direta e indiretamente, e os incêndios terem passado a ser encarados como uma fatalidade, quando na realidade não o são!

Por outro lado, se bem que a segurança dos combatentes sempre tenha sido considerada uma prioridade, após a morte dos quatro bombeiros que foram encurralados pelas chamas em 2013, na serra do Caramulo, essa prioridade saiu reforçada, passando a sobrepor-se a outras, o que certamente teve interferência no modo de intervenção e na forma de realização de certo tipo de intervenções, que a acontecerem de outro modo poderiam contribuir para ajudar a minimizar os danos.

Da conjugação de alguns destes factores, bem como de outros que dizem respeito a situações locais, o resultado dos dois últimos anos, 2016 e 2017, em termos de incêndios em interfaces, apresentou um cenário pouco animador, de que referimos algumas situações.

\subsubsection{6 e 2017 - Incêndios em interfaces urbano-florestais}

Em relação aos incêndios florestais de 2016, duas referências aos que foram mais mediáticos, o primeiro pela dimensão da área ardida, e o segundo por ter penetrado no interior da cidade do Funchal.

O incêndio que ficou conhecido como sendo de Arouca, decorreu entre 7 e 17 de agosto de 2016, tendo queimado 21910 ha e obrigado à evacuação de várias aldeias (Rainha e Lourenço 2017).

Além de que possamos questionar se, nestas circunstâncias, a evacuação total será a melhor solução, não o iremos fazer, mas antes perguntar porque é que haverá necessidade de proceder a essas evacuações. A resposta parece óbvia, pois resulta do facto dos combustíveis existentes nas respetivas interfaces não estarem convenientemente geridos e, por isso, as chamas poderem acercar-se das aldeias e, eventualmente, até nelas penetrar.

A lição a retirar parece bem clara, mas, apesar disso, em termos práticos, ou seja, de aplicação futura, de nada serviu, uma vez que se tivessem sido aplicadas poderiam ter evitado muitas das dramáticas situações que se registaram em 2017 !

Aconteceu que, enquanto decorria este incêndio, um outro, que lavrou entre 8 e 13 de agosto de 2016, foi notícia em todo o mundo, não só por ter afetado 
uma região turística de renome mundial, a ilha da Madeira, mas também e sobretudo por se ter desenvolvido em áreas de interface urbano-florestal e penetrado no interior da cidade do Funchal, tendo ocasionado danos muito avultados: 4 mortos; 2 feridos graves; 1000 desalojados; 300 edifícios danificados, entre moradias, comércio e serviços, dos quais 177 ficaram totalmente destruídos e 123 parcialmente; e, ainda, devido à inalação de fumos, mais de 320 pessoas foram hospitalizadas.

O jornal Público, do dia 14 de agosto de 2016, a propósito desse cenário dantesco que correu mundo, interrogava sobre as razões porque arde uma cidade, ilustrando com uma imagem elucidativa (fot. 5) e dando uma resposta, através do responsável pela Ordem dos Arquitetos na Madeira, cuja explicação resultou do "caos urbanístico das zonas altas e do abandono dos edifícios históricos» da cidade. Certamente que esses foram factores importantes, mas o jornalista Márcio Berenguer acrescenta outro aspeto não menos importante e, para nós, determinante: «o problema, e a solução, residem bem mais acima, na periferia do Funchal, onde a cidade e floresta se confundem. Foi ali que tudo começou. Tal como no grande incêndio do Verão de 1593, que baptizou as ruas da Queimada de Cima e de Baixo, o combustível para a tragédia estava ali, onde sempre tem estado».

Por isso, não podemos deixar de acrescentar que o problema está na gestão desse combustível. Além disso, o responsável pela Ordem dos Arquitetos considerou que "é preciso agir já, para que estas tragédias deixem de ser cíclicas", afirmação com a qual não podemos deixar de estar mais de acordo (fot. 5).

Não obstante essa urgência, esse «já» só teve resposta cerca de um ano depois e, curiosamente, tal sucedeu só após se terem registado os violentos incêndios de 17 a 24 de junho, no continente, como o jornalista Márcio Berenguer voltou a noticiar no Público, a 8 de julho de 2017. Tratar-se-á, certamente, apenas de coincidência, mas não deixa de se notar e realçar a relação existente entre certas coincidências.

Assim, sob o título Madeira cria faixa corta-fogo para proteger o Funchal, o jornalista informa de que os eucaliptos, as acácias e giestas - plantas que possuem elementos que potenciam a propagação das chamas, como óleos inflamáveis serão substituídas por folhosas de crescimento lento, com elevado teor de água, como é o caso dos castanheiros, carvalhos e de espécies indígenas. 


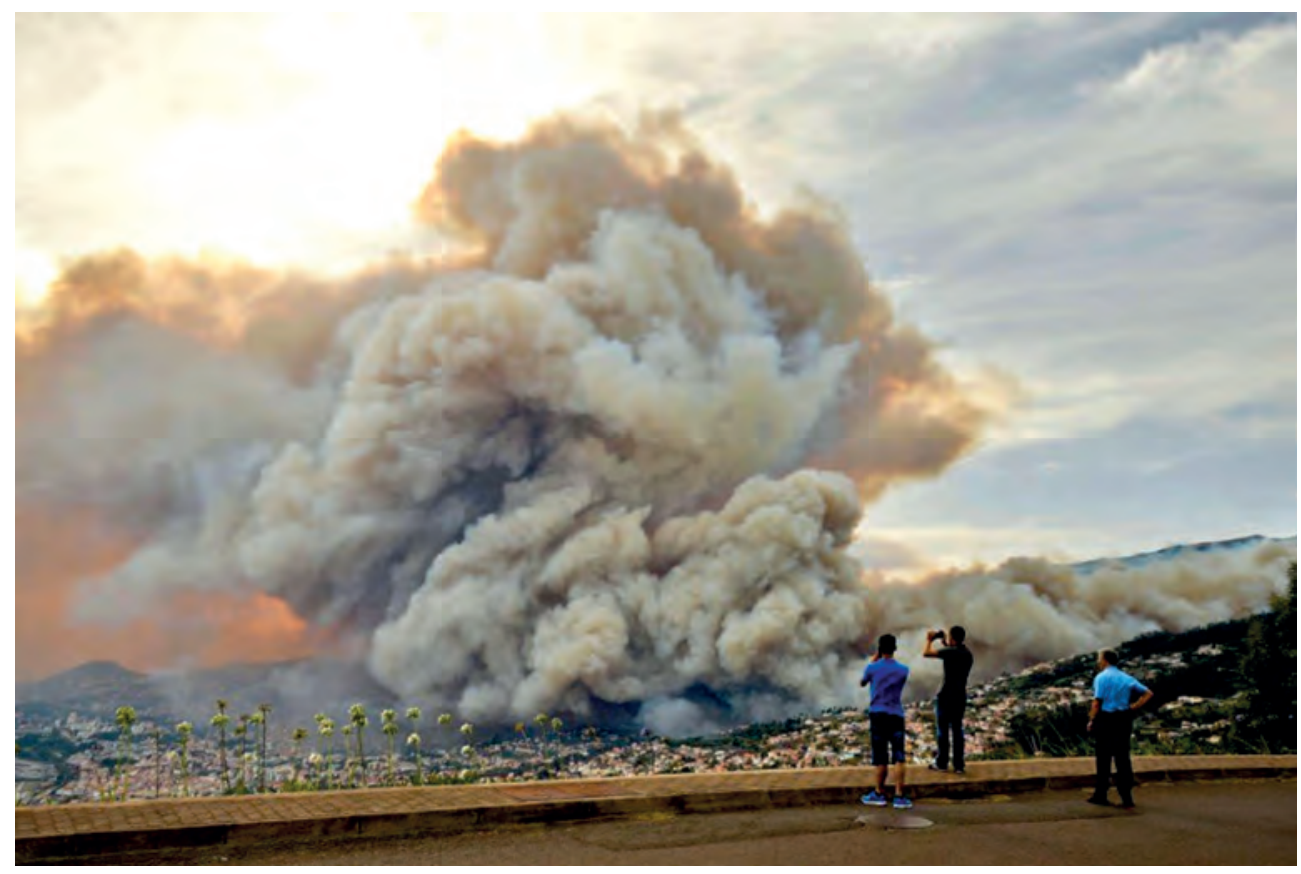

Fot. 5. Vista do incêndio de agosto de 2016, dirigindo-se para a cidade do Funchal (Fotografia de Joana Sousa / AFP PHOTO; Fonte: Público, 14 de agosto de 2016)

Além disso, o projeto do governo madeirense prevê a construção de uma rede de caminhos agrícolas com bocas de incêndio, projeto que será implantado numa área de 420 hectares, por ser das mais fustigadas pelos incêndios que, ciclicamente, têm assolado a ilha (fot. 6), criando «uma barreira que impede a passagem do fogo, facilitando o trabalho dos bombeiros e evitando incêndios de grande dimensão e intensidade», no dizer da Secretária Regional do Ambiente e Recursos Naturais.

A notícia dá conta de que os trabalhos de gestão de combustível já se encontravam a decorrer em cerca de 81 hectares, em paralelo com outros trabalhos, desenvolvidos por privados e financiados por fundos comunitários. Acrescentava ainda que «nos caminhos agrícolas serão instaladas bocas de incêndio de $500 \mathrm{em}$ 500 metros (250 metros nas zonas sinalizadas como sendo mais críticas), que serão alimentadas por uma rede de tanques de água e por um reservatório com capacidade para 1500 metros cúbicos, a ser construído» e concluía dizendo que 
este «reservatório servirá, futuramente, os meios aéreos de combate que venham a ser colocados no arquipélago».

Sobre o assunto dos meios aéreos para combate a incêndios florestais na região, já nos pronunciámos em devido tempo (Lourenço et al. 2010) e não temos qualquer dúvida de que se as soluções que então foram proposta e que agora começam a ser implementadas, se vierem a ser concretizadas, dispensarão a colocação de meios aéreos no arquipélago para combate a incêndios florestais.

O tempo dirá se as soluções técnicas recomendadas, por serem as mais adequadas à gestão de combustíveis e à criação de emprego na floresta, virão a ser implementadas e, sobretudo, se serão mantidas, ou se, pelo contrário, a decisão política privilegiará, uma vez mais, o combate através de meios aéreos e da mediatização a eles associada.

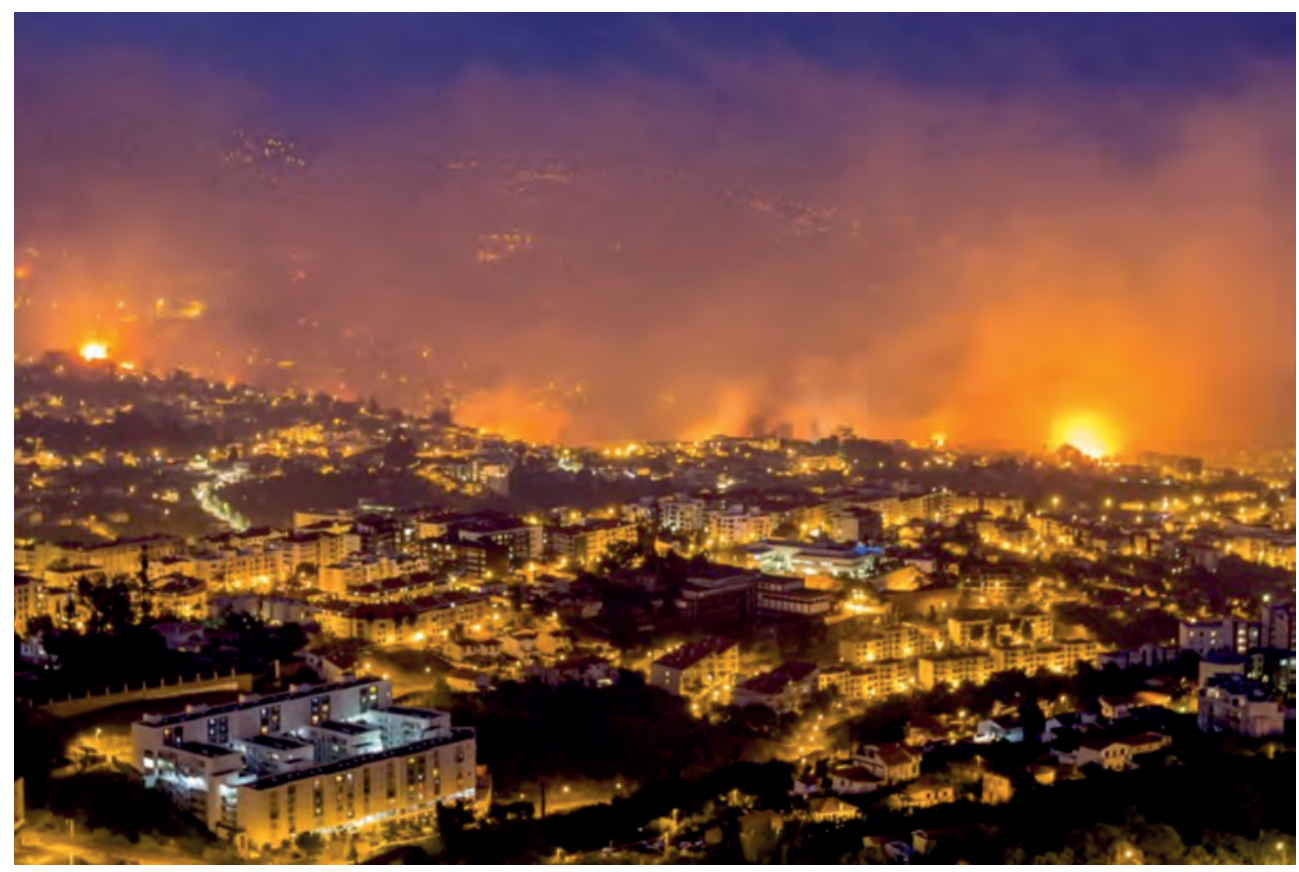

Fot. 6. Aspeto do incêndio de agosto de 2016, no interior da cidade do Funchal (Fotografia de Gregório Cunha / LUSA; Fonte: Público, 8 de julho de 2017) 
Voltando ao continente, o ano de 2017 destacou-se, em termos de incêndios florestais, por ser aquele que registou o maior valor anual de área ardida (fig. 4) e, sobretudo, por ter produzido um número de vítimas mortais incomparável com qualquer registo anterior, uma vez que esse valor (de 116, na atualização de 25 de março) foi superior ao somatório de todas as mortes anteriormente contabilizadas em incêndios florestais.

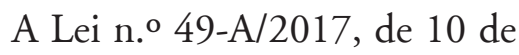
julho, criou uma Comissão Técnica Independente «para a análise célere e apuramento dos factos relativos aos incêndios que ocorreram em Pedrógão Grande, Castanheira de Pêra, Ansião, Alvaiázere, Figueiró dos Vinhos, Arganil, Góis, Penela, Pampilhosa da Serra, Oleiros e Sertã entre 17 e 24 de junho de 2017» e, depois, viu prorrogado o seu mandato para analisar os incêndios de 15 de outubro.

Como esta Comissão bem apurou, as circunstâncias em que se deram as fatalidades (fig. 5), designadamente em termos da gestão dos combustíveis na proximidade dos locais e da relação entre as vítimas e as casas (CTI 2017), podemos concluir que muitas delas teriam sido evitadas se, previamente, tivesse existido adequada gestão do combustível existente nas áreas de interface urbano-florestal.

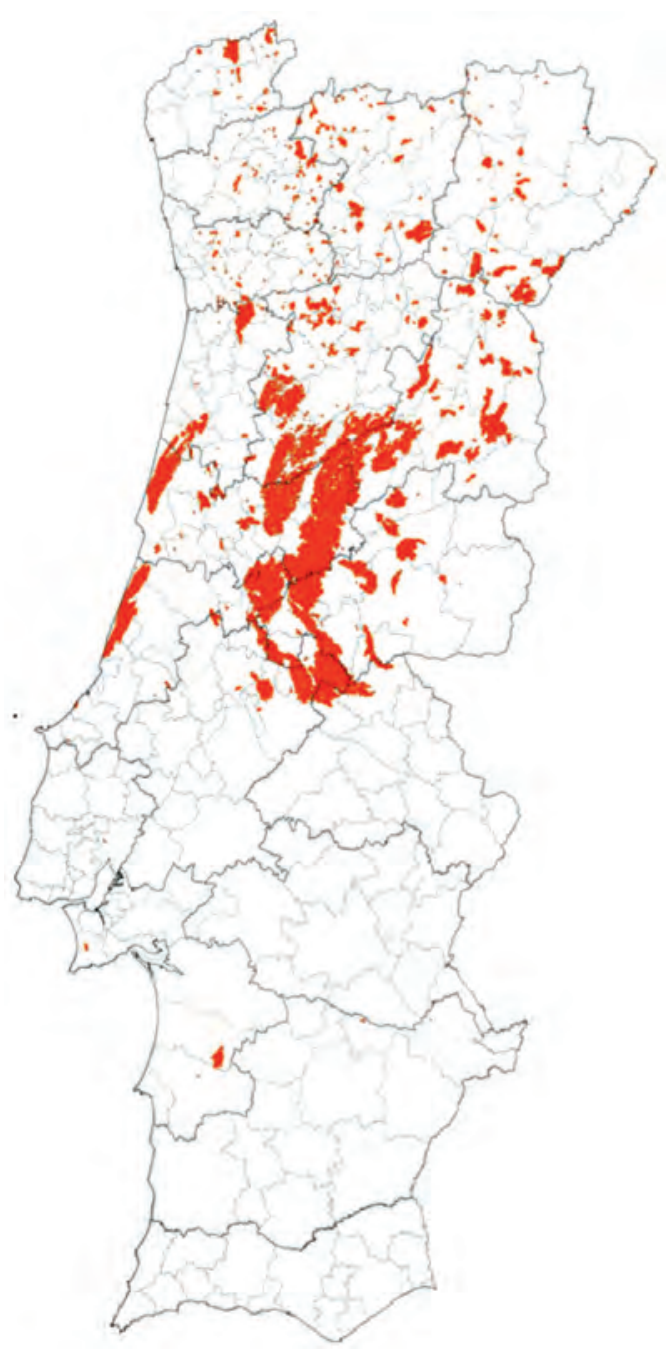

Fig. 4. Distribuição espacial dos incêndios florestais em Portugal Continental no ano de 2017 (Fonte: ICNF 2017) 


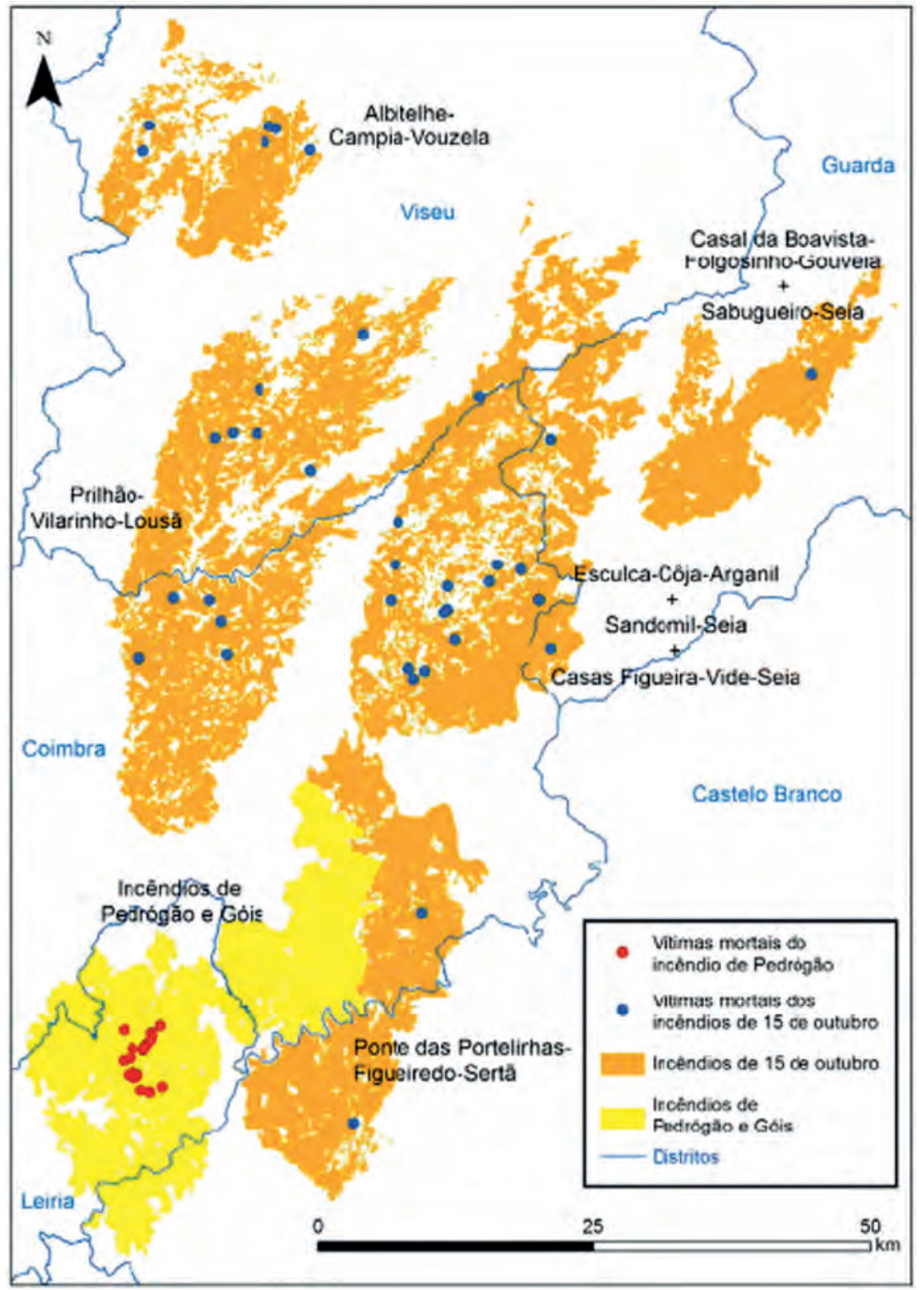

Fig. 5. Distribuição geográfica dos 38 locais onde ocorreram vítimas mortais na sequência dos incêndios de 15 de outubro e dos 20 locais onde ocorreram vítimas mortais na sequência do incêndio de Pedrogão (Fonte: CTI 2018: 128) 
Com efeito, as vítimas que encontraram a morte na EN 236-1 só abandonaram as suas residências porque nelas não se sentiram seguras, dada a proximidade da floresta, o mesmo tendo sucedido em alguns dos incêndios ocorridos entre 14 e 16 de outubro de 2017 (CTI 2018).

De facto, estes incêndios, embora menos mediatizados, foram ainda mais graves do que os do anterior mês de junho. No entanto, como é sabido, os objetivos da comunicação social nem sempre se pautam pelos objetivos da defesa da floresta contra incêndios, pelo que não nos vamos pronunciar sobre a forma como foram conduzidas muitas das entrevistas realizadas nos teatros de operaçôes, nem como foram organizados muitos dos debates com «especialistas», nem sobre o conteúdo de algumas reportagens e nem sequer sobre a divulgação de certas notícias... dado que, por vezes, não informaram corretamente os espetadores.

$\mathrm{Na}$ realidade, além dos problemas já mencionados nas interfaces urbano-florestais, estes incêndios devastaram áreas emblemáticas da história florestal portuguesa, como foi o caso não só da Mata Nacional de Leiria, também conhecida por Pinhal do Rei, que permanecerá para sempre ligada à história de Portugal, dado que terá sido pioneira na fixação das areias eólicas, no ordenamento florestal, nos ensaios de fogo controlado ou na conservação e aproveitamento dos recursos naturais, mas também de outras áreas dunares do litoral, igualmente incineradas, como sucedeu na confinante Mata do Urso ou nas Matas das Dunas de Quiaios, Tocha e Mira, a Norte do rio Mondego.

Outros dois importantes símbolos florestais, com importantes Reservas Biogenéticas, foram igualmente afetados por incêndios nestes dias de outubro. A Mata da Margaraça, uma das raras relíquias da vegetação espontânea original do Centro do País, situada na serra do Açor e que constitui um dos últimos redutos da tradicional paisagem serrana, e o Parque Natural da Serra da Estrela, que, pela sua importância internacional para a conservação da natureza, integra a Rede Natura 2000 e que, ao longo dos anos, tem sido pasto de vários grandes incêndios.

Além das vítimas mortais e dos danos causados nos ecossistemas, estes incêndios de 15 de outubro também ficarão retidos na memória de todos quantos a eles assistiram devido aos danos causados nas interfaces urbano-florestais, tanto em centenas de habitações, como em infraestruturas empresariais, já que foram danificadas mais de 500 empresas, distribuídas por 30 municípios, dos quais os 
mais afetados foram os de: Oliveira de Frades, Oliveira do Hospital, Mira, Cantanhede, Mortágua e Tondela (CTI 2018).

Estamos convictos de que os avultados prejuízos resultantes destes incêndios e, sobretudo, as mortes que ocasionaram serão suficientes para que os governantes portugueses passem a olhar de outra forma para os territórios do interior, no sentido de contribuírem para o seu desenvolvimento sustentável, já que será a única forma de neles manter a população, envolvendo-a na gestão da floresta, para que esta possa voltar a ser uma atividade geradora de riqueza e de emprego, que não se esgota na produção de lenho e que, na sua faceta de uso múltiplo, poderá ser o motor de desenvolvimento do interior.

\section{CONCLUSÃO}

Apesar do tempo que, entretanto, decorreu após os incêndios florestais do ano de 2017, dos vários relatórios efetuados e dos múltiplos debates realizados, em Portugal continuam a subsistir muitas dúvidas sobre o que aconteceu e, sobretudo, porque aconteceu.

Com efeito, todos os incêndios começam por ser pequenos, com ou sem tempestades, sejam Ophelia ou outras...

De facto, a Ophelia afetou praticamente todo o Centro e Norte de Portugal, mas felizmente nem toda a floresta foi queimada!

Então, parece lógico interrogar-nos sobre o porquê de uns incêndios serem apagados no ataque inicial e outros não?

A resposta não terá apenas a ver com os processos inerentes ao combate, que envolvem os meios de combate, a formação dos combatentes, o comando da operação..., uma vez que também diz respeito às vulnerabilidades existentes na área em que se desenvolvem as operações de combate, as quais poderiam ter sido reduzidas previamente ou, porventura, até eliminadas, se tivesse havido prevenção, estrutural e conjuntural, algo que tarda em efetivar-se de forma consistente e contínua, mas que é fundamental para aumentar a eficácia do combate.

Como somos apologistas de coisas simples, mesmo quando associadas ao desenvolvimento tecnológico, não só para que sejam de fácil aplicação, mas também e sobretudo para não consumirem demasiados recursos financeiros, que 
farão falta para aplicar noutras medidas, cremos que as faixas de gestão de combustíveis, em redor dos aglomerados populacionais e das casas isoladas, podem ser apontadas com um bom exemplo de medida mitigadora para reduzir quer o impacte dos incêndios nas interfaces urbano florestais, quer para facilitar a extinção de incêndios. Em segundo lugar, somos também favoráveis à instituição de procedimentos de melhoria contínua, uma prática que merece ser instituída, em substituição das frequentes mudanças que quebram a continuidade e não permitem fechar ciclos e proceder à respetiva avaliação, mudanças que deverão passar a ser exceção, sempre que tal se justifique, mas não a regra de normal funcionamento.

Esperemos que os incêndios florestais de 2017 contribuam definitivamente para alterar o panorama de desinvestimento no interior de Portugal e permitam que ele volte a ser um país de floresta geradora de riqueza e bem estar, onde os incêndios florestais voltem a ser exceção e não a regra que marca a cadência do verão! 


\section{REFERENCIAS BIBLIOGRÁFICAS}

Berenguer, Márcio (2016): «Funchal: porque arde uma cidade?», Público, 14 de agosto.

Berenguer, Márcio (2017): «Madeira cria faixa corta-fogo para proteger o Funchal», Público, 8 de julho. CTI - Comissão Técnica Independente (2017): Análise e apuramento dos factos relativos aos incêndios que ocorreram em Pedrógão Grande, Castanheira de Pera, Ansião, Alvaiázere, Figueiró dos Vinhos, Arganil, Góis, Penela, Pampilhosa da Serra, Oleiros e Sertã, entre 17 e 24 de junho de 2017, Assembleia da República, março, $296 \mathrm{p}$.

CTI - Comissão Técnica Independente (2018): Avaliação dos incêndios ocorridos entre 14 e 16 de outubro de 2017 em Portugal Continental, Assembleia da República, outubro, 276 p.

FERnandes, José Manuel Henriques David (2013): Risco de Incêndio Florestal em Areas de Interface Urbano-Rural - O exemplo das Bacias Hidrográficas das Ribeira de Alge e Pera. Dissertação de Mestrado em Geografia Física, na área de especialização em Geografia Física, Ambiente e Ordenamento do Território. Departamento de Geografia da Faculdade de Letras da Universidade de Coimbra, 147 p.

Fernandes, Sofia Pires (2015): Incêndios florestais em Portugal Continental fora do "periodo crítico». Contributos para o seu conhecimento. Dissertação de Mestrado em Geografia Física, do Departamento de Geografia da Faculdade de Letras da Universidade de Coimbra, 234 p.

FIDALGO, E. (2013): «Risco de incêndios na interface urbano-florestal: reflexão conceptual», Territorium, 20, 101-114.

ICNF - Instituto da Conservação da Natureza e das Florestas (2017): 10. Relatório Provisório de Incêndios Florestais - 2017. 01 de janeiro a 31 de outubro, Departamento de Gestão de Áreas Públicas e de Proteção Florestal, 19 p.

Lourenço, Luciano (1996): «Coimbra e os Riscos Naturais. Passado e presente», Cadernos de Geografia (Número especial), Coimbra, 37-43.

LOURENÇO, Luciano (2007): «Incêndios florestais de 2003 e 2005. Tão perto no tempo e já tão longe na memória!», en Luciano Lourenço (coord.), Riscos Ambientais e Formação de Professores (Atas das VI Jornadas Nacionais do PROSEPE), Coimbra, Projecto de Sensibilização e Educação Florestal / Núcleo de Investigação Científica de Incêndios Florestais / Faculdade de Letras da Universidade de Coimbra, 19-91. (Colectâneas Cindínicas; VII).

LOURENÇO, Luciano (2008): «Urban-Forest Interfaces: a Favourable Stage for the Incidence and Development of Forest Fires in Portugal», Australasian Journal of Disaster and Trauma Studies, Volume: 2008-2.

LOURENÇO, Luciano (2009): «Plenas manifestaçôes do risco de incêndio florestal em serras do Centro de Portugal. Efeitos erosivos subsequentes e reabilitaçôes pontuais», Territorium, Revista da Associação Portuguesa de Riscos, Prevenção e Segurança, Lousã, 16, 5-23.

LourenÇO, Luciano / António Bento-GonÇALves / João Rocha / Flora Ferreira-Leite / Carla Martins (2010): Plano Estratégico para o Dispositivo de Socorro e Emergência da Regiāo Autónoma da Madeira. Proposta Técnica. Universidade de Coimbra, 160 p. (inédito).

RAINHA, Manuel / Luciano LOURENÇO (2017): Incêndios florestais do maciço da Gralheira entre 6 e 8 de agosto de 2016. Forest fires in the Gralheira massif between August 6th and 8th 2016. Livro-Guia da Visita Técnica n. ${ }^{\circ}$ 1. IV Congresso Internacional de Riscos, Coimbra, RISCOS - Associação Portuguesa de Riscos, Prevenção e Segurança, 84 p.

Vieira, António / António Bento-GonçAlves / Luciano Lourenço / Carla Martins / Flora FerreiRA-LeITE (2009): «Risco de incêndio florestal em áreas de interface urbano-rural: O exemplo do Ave», Territorium, Revista da Associação Portuguesa de Riscos, Prevenção e Segurança, Lousã, 16, 139-146. 


\section{PREPARAÇÃO DO SISTEMA DE DEFESA PARA COMPORTAMENTO EXTREMO DO FOGO}

António Salgueiro

GIFF (Gestão Integrada e Fomento Florestal) 

A tendência crescente, que se tem verificado nos últimos anos, em particular em Portugal (2003, 2005, 2013, 2017), do aumento da dimensão e da superfície percorrida pelos incêndios florestais, afetando cada vez mais pessoas, com maior número de vítimas e impacto sobre património natural e construído, implicam um aumento do número de pessoas e de bens a proteger prioritariamente durante a emergência.

Tem-se vindo também a registar um aumento de fogos com comportamento extremo, designados nalguma bibliografia como megafogos (megafires), pela sua extraordinária dimensão, intensidade que ultrapassa qualquer capacidade de extinção, e pelos elevados impactos socio-económicos, com percas de vidas e elevados prejuízos económicos dentro e fora do setor e dos espaços florestais.

Estas situações exigem uma maior priorização na proteção e no socorro de pessoas e a bens, afetando frequentemente a disponibilidade de meios para a contenção da propagação do fogo nos espaços florestais, aumentando assim a sua extensão e a probabilidade de afetar ainda mais pessoas e bens.

Em 2017 ocorreram em Portugal muitas destas situações com vários mega-incêndios que ultrapassaram, nalgumas situações durante várias horas, qualquer capacidade de extinção, condicionando a possibilidade de intervenções exclusivamente ao socorro às populações, não permitindo a execução de ações de contenção do fogo.

No incêndio rural de Pedrogão Grande, ocorrido entre os dias 17 (início às 14h30) e 20 de Junho de 2017, registaram-se, entre as $19 \mathrm{~h} 00$ e as $21 \mathrm{~h} 00$ do primeiro dia, parâmetros de comportamento do fogo e impactos raramente observados, nomeadamente: velocidade de propagação média de $3,9 \mathrm{~km} / \mathrm{h}$, atingido momentaneamente $15,2 \mathrm{~km} / \mathrm{h}$ (associadas a downburst); intensidades frontais entre 20000 e $60000 \mathrm{~kW} / \mathrm{m}$ (considerado comportamento extremo acima dos $10000 \mathrm{~kW} / \mathrm{m}$ ); velocidade de expansão perimetral de cerca de $3500 \mathrm{ha} / \mathrm{h}$; formaçãao de piro-cumulonimbo; deslocação da coluna do incêndio a uma velo- 
cidade de $5 \mathrm{~km} / \mathrm{h}$, atingindo um altitude de $13 \mathrm{~km}$ (ultrapassando a troposfera e alcançando a tropopausa); ocorrência de 48 (75\%), do total das 64 fatalidades registadas no período entre as 20:05 e as 20:15 (10’), ao longo de cerca de $11 \mathrm{~km}$. Tratava-se à data do maior fogo florestal registado no país, tendo sido percorridos pelo fogo entre os dias 17 e 20 de Junho cerca de 50000 ha.

Durante o Verão, após o incêndio de Pedrogão, registar-se-iam vários outros Grandes Incêndios Florestais (GIF, ocorrências com mais de 100 ha), mas a pior situação viria a registar-se no dia 15 de outubro, sob a influência do furacão Ophelia - ventos fortes e secos com temperaturas elevadas - e do estado de seca severa da maioria do país $(81 \%)$ e da Galiza. Nesse dia registaram-se 440 ocorrências, que provocaram cerca de 50 mortos, queimaram milhares de casas e destruíram mais de 500 instalaçôes de empresas, muitas delas localizadas em polígonos industriais. Nesse dia e nos 2 que se seguiram arderiam cerca de 225000 ha. Durante esse ano registaram-se 214 incêndios com mais de 100 ha (responsáveis por $93 \%$ da área ardida), dos quais $62 \mathrm{com}$ áreas superiores a 1000 ha, e 11 superiores a 11000 ha, tendo ocorrido os 5 maiores incêndios de todos os tempos. No total registou-se uma área total ardida de cerca de 540000 ha, e seriam registados valores recordes de índice de perigo meteorológico de incêndio (Fire Weather Index, do sistema canadiano adaptado para Portugal por Paulo Fernandes).

Nesse ano de 2017, outras áreas do mundo sofreriam de forma contundente o impato de mega-incêndios florestais, nomeadamente na Galiza, no Chile, no Canada, nos EUA ou na Africa do Sul.

Para além das questōes meteorológicas, que outras causas poderão estar na origem destes acontecimentos catastróficos de dimensão desmesurada? Desde logo um uso exagerado do fogo, muitas vezes sem qualquer sentido pratico ou objetivo, em queimas ou queimadas em momentos completamente desajustados (cerca de 2/3 das ocorrências devem-se a negligência em Portugal). As condições estruturais terão também influência crescente na dificuldade de supressão e na exposição ao risco das populações, provocadas nomeadamente pela homogeneização da paisagem, que resultou do abandono de atividades agrárias, e dos grandes incêndios de 2003 e de 2005, que ocorreram nestas regiōes e eliminaram muitos dos mosaicos anteriormente existentes. Ainda ao nível estrutural terá sem dúvida importância preponderante a falta de gestão florestal adequada de 
muitos dos territórios, nomeadamente dos públicos (arderam em 2017 cerca de $47 \%$ das matas nacionais). Na supressão registam-se lacunas ao nível da capacidade de antecipação no âmbito do combate, um desajustamento entre risco e disponibilidade de meios, um elevado desequilíbrio entre os investimentos realizados em meios ou em capacitação e especialização - com larga preponderância para os primeiros - privilegiando-se a quantidade (dos meios) em detrimento da qualidade (dos homens) - e um fraco conhecimento dos espaços florestais da parte dos intervenientes no combate.

No entanto, a eficácia das intervenções tradicionais, ao nível da prevenção e do combate, estão fortemente limitadas em termos de eficácia, pela intensidade da frente de fogo. Comportamentos extremos como as que ocorreram em 2003, 2005 e 2017 em Portugal ultrapassam a capacidade de extinção. Nestas circunstâncias as ações preventivas standards ou regulamentares não provocam alteraçôes na intensidade do fogo que diminuam de forma considerável a sua intensidade, não contribuindo para melhorar as possibilidades e as probabilidades de êxito do combate. Fogos com comportamento extremo criam piro-ambientes e propagam-se frequentemente por focos secundários (saltos de fogo), a várias centenas ou mesmo milhares de metros. Estas situaçóes excepcionais têm vindo a aumentar e, face às alterações climáticas, é expectável que venham a ocorrer com mais frequência, exigindo novas formas de atuação, ao nível, dos espaços, das pessoas e dos dispositivos.

Assumindo que existem limites para a capacidade de extinção, em situações extremas (mesmo menos complexas que os mega-incêndios), o que fazer e como fazer quando esta é ultrapassada e temos simultaneamente: espaços florestais a arder, vida de pessoas e bens construídos em risco? Será possível fazer simultaneamente combate, proteção e socorro, com a mesma tipologia de equipas e as mesmas pessoas? Como organizar o sistema para dar respostas imediatas (socorro) e impedir que o incêndio rural se continue a propagar ou pelo menos estar preparado (por antecipação) para intervir quando existirem oportunidades de combate?

De forma não exaustiva apontam-se para algumas linhas de trabalho, organização e coordenação, algumas das quais emanaram da Comissão Técnica Independente que analisou o incêndio de Pedrógão Grande. Passar de sistemas (difusos) de Defesa da Floresta Contra Incêndios (DFCI) para Sistemas de 
Proteção Contra Incêndios Rurais (PCIR). Adoptar Sistema de Gestão Integrada de Fogos Rurais (SGIFR), subdivididos (mas com coordenação central), para a prevenção e para o combate, em 2 componentes.

\section{PROTEÇÃO CONTRA INCÊNDIOS RURAIS (PCIR) - PREPARAR / ANTECIPAR}

- Sensibilização e educação: eliminar comportamentos de risco (uso do fogo) e preparar as pessoas para comportamentos de autoproteção e de defesa do património.

- Prevenção / preparação: territórios envolventes aos aglomerados (em dimensão adequada ao comportamento esperado do fogo), com baixas cargas, continuidade e inflamabilidade de combustíveis, se possível através de atividades sustentáveis; apoiar, organizar e trabalhar iniciativas e atividades das populações locais (subsidiariedade); identificar e preparar líderes, locais de refúgio e procedimentos de proteção; eliminar fatores de risco de propagação dentro dos aglomerados (edificios devolutos); sobrepor interesse público de proteção civil a interesses ou desinteresses privados; treinar equipas locais para apoio ao combate a incêndios:

- Pré-supressão: comunicar antecipadamente situações potenciais de risco meteorológico extremo às populações e aos agentes de proteção civil; comunicar antecipadamente aproximação de incêndio e comportamento esperado.

- Supressão e socorro: sempre que necessário, deverá ser feito por equipas especificas e exclusivamente dedicadas a estas tarefas.

\section{GESTÃO DE INCÊNDIOS RURAIS (GIR)}

- Sensibilização agressiva e ativa - de proximidade e no terreno, se possível com contacto pessoal - dirigida especificamente para as populações rurais; policiamento ativo e duro dos territórios em situações de perigo elevado. 
- Prevenção: atuar sobre as ignições; eliminar comportamentos de risco, identificando as causas de incêndio e atuando por eliminação ou substituição (uso adequado do fogo); apoiar a existência e sobretudo a manutenção de povoamentos de baixa combustibilidade; apoiar iniciativas de prevenção produtivas e enquadrá-las nas ações de GIR: valorização e proteção florestal, que criem empregos locais e promovam desenvolvimento rural (resinagem, cogumelos, pinhas, etc.); participação das equipas de combate nas ações de prevenção.

- Gestão de combustíveis: Substituir intervenções em faixas (buffers) por intervençôes à escala da paisagem (grandes mosaicos); ir de encontro às necessidades dos utilizadores dos territórios; adotar principíos de gestão estratégica de combustíveis para a sua localização e dimensionamento, adequadas ao comportamento esperado do fogo, à recorrência (antecipar) e valores a proteger, e à tipologia e capacidade do combate; escolher as técnicas de intervenção com base na sua eficiência; usar o mais possível o fogo controlado em matos e sub-coberto, por ser a técnica que permite da forma mais rápida, económica e eficaz a redução/eliminação dos combustíveis finos, servindo também para ações de formação.

- Pré-supressão / preparação: antecipar, com base nas previsões e no histórico, as situaçôes meteorológicas que propiciam condiçôes extremas de propagação do fogo; dimensionar as equipas e a tipologia das intervenções, em função do comportamento esperado do fogo; localizar e distribuir equipas no território, considerando a proximidade aos locais de maior probabilidade de ocorrências e de maior dificuldade de supressão; adequar os procedimentos e a organização da primeira intervenção (ataque inicial), em função do comportamento esperado do fogo (ISI); definir territórios e condiçōes meteorológicas para gerir incêndios de reduzida severidade (incêndios confinados), aproveitando-se oportunidades e evitando-se «a armadilha da extinção»; comunicar ativamente às populações - comunicação social, web, rede móvel - as consequências de determinados comportamentos em situações extremas, utilizando por exemplo imagens de fatalidades 2017, Guadalajara, etc. 
- Supressão: o fogo florestal tem comportamentos relativamente previsíveis a algumas horas de distância, pelo que se deve aproveitar ao máximo esta possibilidade para trabalhar por antecipação; privilegiar as intervenções em função da sua probabilidade de êxito e do potencial futuro de expansão do incêndio; assumir que o combate tem capacidades limitadas e que fora da capacidade de extinção não devem ser desencadeadas ações de supressão; dotar as equipas de combate de analistas de incêndios e de profundos conhecedores dos territórios; estudar e aprender o mais possível com os incêndios e intervenções do passado. 



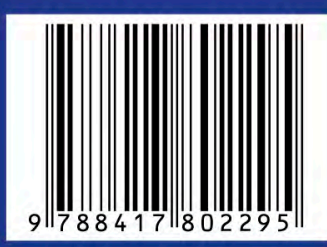

Nos últimos tempos estase a constatar que os incendios forestais afectan cada vez con máis virulencia a edificacións e persoas. Esa interface urbano-forestal, que até hai pouco só illadamente era pasto das lapas, agora vese decote ameazada polos lumes, de tal xeito que a súa protección se converte no obxectivo prioritario das operacións de extinción. Así mesmo, semella que a extensión e a intensidade dos incendios se van incrementando como consecuencia de situacións meteorolóxicas especialmente adversas, que se suman ao amoreamento excesivo de combustibles. Para moitos, o cambio climático pode estar detrás destas novas condicións.

Todo o anterior leva a diversos analistas a indicar que estamos diante dun cambio cualitativo na incidencia e características dos incendios forestais que non fará máis que incrementarse nos próximos anos. Fálase dunha nova xeración de lumes.

Para tratar destes temas, nuns territorios tan castigados polos incendios como son Galicia e Portugal, o Consello da Cultura Galega organizou un coloquio no mes de xaneiro do 2018 no que se presentaron os relatorios que se recollen nesta publicación.

\section{Consello da Cultura Galega}

